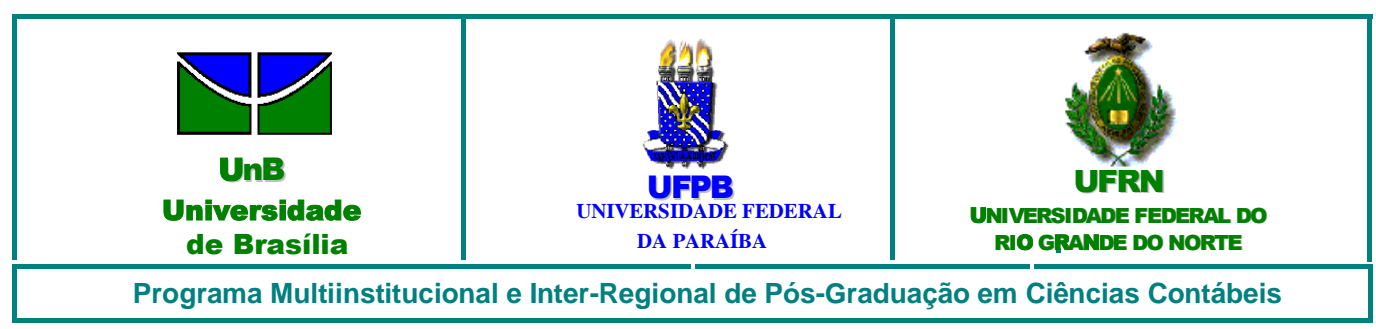

TESE

Giovanni Pacelli Carvalho Lustosa da Costa

OS IMPACTOS DAS FUNÇÕES ORÇAMENTÁRIAS ALOCATIVA E DISTRIBUTIVA SOBRE A DESIGUALDADE DE RENDA: UMA ANÁLISE SOBRE UNIDADES DA FEDERAÇÃO BRASILEIRA ENTRE 1995 E 2012

BRASÍLIA/DF

2016 
Professor Doutor Ivan Marques de Toledo Camargo

Reitor da Universidade de Brasília

Professora Doutora Sônia Nair Báo

Vice-Reitora da Universidade de Brasília

Professor Doutor Jaime Martins de Santana

Decano de Pesquisa e Pós-graduação

Professor Doutor Roberto de Goes Ellery Júnior

Diretor da Faculdade de Economia, Administração e Contabilidade

Professor Doutor José Antônio de França

Chefe do Departamento de Ciências Contábeis e Atuariais

Professor Doutor Rodrigo de Souza Gonçalves

Coordenador-geral do Programa Multi-institucional e Inter-regional de Pós Graduação em Ciências Contábeis da UnB, UFPB e UFRN 


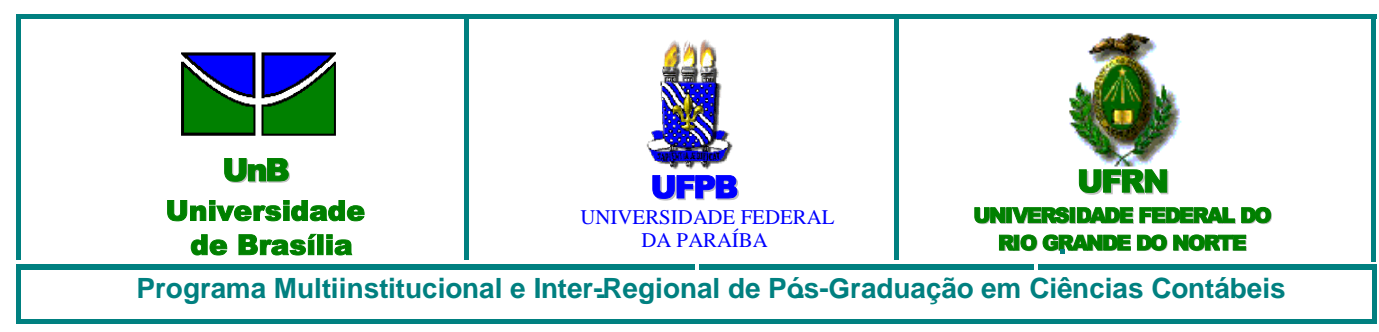

Giovanni Pacelli Carvalho Lustosa da Costa

\section{OS IMPACTOS DAS FUNÇÕES ORÇAMENTÁRIAS ALOCATIVA E DISTRIBUTIVA SOBRE A DESIGUALDADE DE RENDA: UMA ANÁLISE SOBRE UNIDADES DA FEDERAÇÃO BRASILEIRA ENTRE 1995 E 2012}

Tese apresentada ao Programa Multiinstitucional e Inter-Regional de PósGraduação em Ciências Contábeis da Universidade de Brasília, da Universidade Federal da Paraíba e da Universidade Federal do Rio Grande do Norte como requisito à obtenção do título de Doutor em Ciências Contábeis.

Área de Concentração: Mensuração Contábil

Linha de Pesquisa: Contabilidade para Tomada de Decisão

Orientador: Dr. Ivan Ricardo Gartner 
Costa, Giovanni Pacelli Carvalho Lustosa da

Os impactos das funções orçamentárias alocativa e distributiva sobre a desigualdade de renda: uma análise sobre unidades da federação brasileira entre 1995 e 2012 / Giovanni Pacelli Carvalho Lustosa da Costa; orientador Dr. Ivan Ricardo Gartner. -- Brasília, DF, 2016. $147 \mathrm{p}$.

Tese (Doutorado em Ciências Contábeis) - Universidade de Brasília. Faculdade de Economia, Administração e Ciências Contábeis e Atuariais - FACE. Programa Multiinstitucional e Inter-Regional de Pós-Graduação em Ciências Contábeis (UnB/UFPB/UFRN), 2016.

1. Função alocativa. 2. Função distributiva. 3. Desigualdade de renda. 4. Eficiência no setor público. I. Gartner, Ivan Ricardo. II. Título. 


\title{
OS IMPACTOS DAS FUNÇÕES ORÇAMENTÁRIAS ALOCATIVA E DISTRIBUTIVA SOBRE A DESIGUALDADE DE RENDA: UMA ANÁLISE SOBRE UNIDADES DA FEDERAÇÃO BRASILEIRA ENTRE 1995 E 2012
}

Tese apresentada ao Programa Multiinstitucional e Inter-Regional de PósGraduação em Ciências Contábeis da Universidade de Brasília, da Universidade Federal da Paraíba e da Universidade Federal do Rio Grande do Norte como requisito à obtenção do título de Doutor em Ciências Contábeis.

Comissão avaliadora:

\section{Professor Doutor Ivan Ricardo Gartner \\ Universidade Federal de Brasília - UnB \\ (Presidente da Banca)}

\author{
Prof. Dr. Paulo Roberto Barbosa Lustosa \\ Universidade Federal de Brasília - UnB \\ (Membro Interno Vinculado - PPGCC UnB/UFPB/UFRN) \\ Prof. Dr. Rodrigo de Souza Gonçalves \\ Universidade Federal de Brasília - UnB \\ (Membro Interno Vinculado - PPGCC UnB/UFPB/UFRN)
}

Prof. Dr. Tito Belchior Silva Moreira

(Membro Externo - Universidade Católica de Brasília)

Prof. Dr. Rogério Boueri Miranda

(Membro Externo - IPEA) 
A toda a minha família.

A minha esposa Danielle e ao meu filho João Pedro.

Aos meus pais Eugênio e Rosa.

Aos meus irmãos João Paulo e Nádia.

À minha sogra Mazônia 


\section{AGRADECIMENTOS}

Meu primeiro agradecimento vai ao meu orientador Prof. Dr. Ivan Ricardo Gartner e a comissão de seleção do Doutorado, os quais me deram o voto de confiança para integrar a $6^{\mathrm{a}}$ turma de Doutorado do Programa Multiinstitucional e Inter-Regional de PósGraduação em Ciências Contábeis UnB/UFPB/UFRN.

Agradeço do mesmo modo a todos os professores que participaram na difusão do conhecimento em 2013 e 2014: Dr. Jorge Katsumi Niyama; Dr. César Augusto Tibúrcio Silva; Dr. Edilson Paulo; e Dr. Paulo Roberto Barbosa Lustosa; Dr. José Matias Pereira. Os senhores foram muito importantes para o sucesso dessa jornada.

Agradeço novamente ao Prof. Dr. Ivan Ricardo Gartner pelo suporte na etapa mais importante desse ciclo: o desenvolvimento da tese. Seus apontamentos e orientações foram cruciais para o sucesso do meu sonho de obter o título de doutor em ciências contábeis. Obrigado por ter acreditado no meu potencial e pela oportunidade na escolha do tema aqui apresentado.

Apesar de tentar resumir em poucas palavras os principais atores envolvidos neste processo, nada disso teria sido possível sem a benção de Deus que protegeu a mim e à minha família neste período. Obrigado Deus por tudo.

Agradeço aos meus pais, Eugênio e Rosa, pelos ensinamentos de vida a mim transmitidos e úteis, tanto neste desafio, quanto nos outros que me trouxeram até aqui. Sou muito grato pela presença física e afetiva de vocês nesse momento importante.

Agradeço aos meus irmãos João Paulo e Nádia Horn, que já se sagraram respectivamente como doutor e mestre; o sucesso de vocês motivou ainda mais a minha jornada. Agradeço ao meu cunhado Denny Horn pelo interesse em prestigiar a defesa da tese.

Agradeço à minha esposa, Danielle Sampaio, pela compreensão e apoio devido à minha ausência como esposo e amigo. Agradeço ao meu filho, João Pedro, que apesar de não compreender plenamente o contexto pelo qual passei nestes últimos anos, também sentiu falta da minha presença e atenção, assim como me deu forças e inspiração. Agradeço à minha sogra, Mazônia, que reforçou a ajuda aos cuidados do meu filho João Pedro neste período.

Agradeço aos meus chefes que me incentivaram nessa fase: Carlos Higino Ribeiro de Alencar, Eveline Martins Brito e Valdir Agapito Teixeira.

Agradeço aos servidores da Secretaria do Programa Multiinstitucional e Interregional, em especial a servidora Inez Guedes, pela atenção dispensada. 
A educação exige os maiores cuidados, porque influi sobre toda a vida. 


\section{RESUMO}

A desigualdade de riqueza é um fenômeno presente na sociedade mundial atual. Estudos recentes apontam que $71 \%$ dos adultos mais pobres acumulam $9 \%$ da riqueza, enquanto $0,7 \%$ dos adultos mais ricos acumulam 45,2\% da riqueza. A fim de reverter esse cenário desigual, o Estado pode atuar utilizando a funções orçamentárias alocativa e distributiva. Dessa forma, este estudo busca avaliar os impactos das funções alocativa e distributiva do orçamento sobre as medidas de desigualdade de renda dos Estados da Federação brasileira no período de 1995 a 2012. O estudo se dividiu em duas fases, cada uma com três hipóteses a serem testadas. Na primeira fase, foram considerados: (i) os efeitos das despesas com educação e saúde sobre a desigualdade de renda; (ii) os efeitos dos impostos progressivos sobre a desigualdade de renda; (iii) os efeitos das transferências de renda direta sobre a desigualdade de renda. Em ambos os casos, utilizam-se os índices de Gini, Theil-T, proporção entre os $10 \%$ mais ricos e os $40 \%$ mais pobres, proporção entre os $20 \%$ mais ricos e os $20 \%$ mais pobres. A relação funcional entre os índices de desigualdade e as funções alocativa e distributiva foi explorada a partir de uma regressão tobit e de uma regressão em painel com efeitos aleatórios. Concluiu-se nessa primeira fase que os gastos na função saúde, o imposto sobre veículos automotores, o imposto sobre transmissão de bens causa mortis e doação, o imposto sobre transferência de bens intervivos e os benefícios de prestação continuada contribuíram para a redução da desigualdade de renda no Brasil nesse período. Na segunda fase, foram considerados: (i) o efeito da eficiência da alocação de recursos financeiros na geração de produtos e serviços em saúde e educação sobre a desigualdade de renda; (ii) o efeito da eficiência da alocação de produtos e serviços na geração de resultados em saúde e educação sobre a desigualdade de renda; (iii) o efeito da eficiência na arrecadação de impostos progressivos sobre a desigualdade de renda. Nesta fase, foi utilizado um método semiparamétrico em dois estágios. No primeiro estágio, se obteve a partir da análise envoltória de dados, os escores de eficiência das unidades da federação em relação a cada hipótese. E no segundo estágio, utilizou-se a regressão tobit e a regressão em painel com efeitos aleatórios. Concluiu-se nessa segunda fase que as unidades da federação mais eficientes na alocação de recursos financeiros da função saúde, na alocação dos produtos e serviços de saúde, na arrecadação do imposto sobre veículos automotores reduziram a desigualdade de renda.

Palavras-Chave: Administração Pública; Finanças Públicas; Economia Regional; Desigualdade de Riqueza; Desigualdade de Renda; Função Alocativa; Função Distributiva; Gastos em Educação; Gastos em Saúde; Impostos Progressivos; Eficiência. 


\begin{abstract}
Wealth inequality is a phenomenon present in the current global society. Recent studies indicate that $71 \%$ of the poorest adults accumulate $9 \%$ of the wealth, while $0.7 \%$ of the richest adults accumulate $45.2 \%$ of the wealth. In order to reverse this unequal scenario, the state can act using the budgetary functions allocative and distributive. Thus, this study aims to assess the impacts of allocative and distributive functions of the budget on income inequality measures of the Brazilian Federation States from 1995 to 2012. The study was divided into two phases, each with three hypotheses to be tested. In the first phase, it was considered: (i) the effects of spending on education and health on income inequality; (ii) the effects of progressive taxation on income inequality; (iii) the effects of direct income's transfers on income inequality. In both cases, it was used the indexes of Gini, Theil-T, ratio between the richest $10 \%$ and poorest $40 \%$, ratio between the richest $20 \%$ and poorest $20 \%$. The functional relationship between inequality indices and the allocative and distributive functions has been explored from a Tobit regression and a regression in panel with random effects. It was concluded in the first phase that spending on health function, motor vehicles tax, the tax on transmission "causa mortis" goods and donation tax donor goods transfer and the benefits of continued provision contributed to the reduction of inequality income in Brazil during this period. In the second phase, it was considered: (i) the effect of the efficiency of the allocation of financial resources in the generation of goods and services in health and education on income inequality; (ii) the effect of the efficiency of the allocation of goods and services to generate results in health and education on income inequality; (iii) the effect of efficiency in the collection of progressive taxation on income inequality. At this stage, it was used a semi-parametric method in two stages. In the first stage, it was obtained from the data envelopment analysis, the efficiency scores of federal units for each hypothesis. In the second stage, we used to tobit regression and the regression panel with random effects. It was concluded in this second phase that the units of the federation more efficient allocation of financial resources for health function in the allocation of health products and services, the collection of motor vehicle tax reduced income inequality.
\end{abstract}

Keywords: Public Administration; Public Finances; Regional Economy; Unequal Wealth; Rent Inequality; Allocative Function; Distributive Function; Education Spending Health Spending; Progressive taxes; Efficiency. 


\section{LISTA DE FIGURAS}

Figura 1 - Formas de mensurar a desigualdade ….............................................................. 9

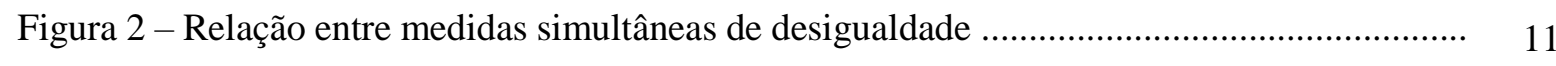

Figura 3 - Formas intervenção estatal na economia............................................................ 19

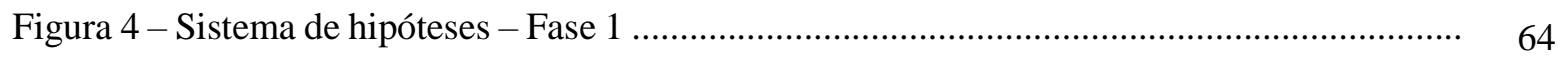

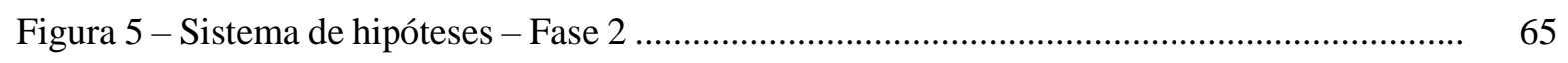

Figura 6 - Função de produção ................................................................................... 82

Figura 7 - Fronteiras CRS, NIRS, NDRS e VRS e as regiões de retornos à escala ......................... 85 


\section{LISTA DE QUADROS}

Quadro 1 - Métodos para evidenciar a desigualdade de renda..................................................... 13

Quadro 2 - Propriedades das medidas para aferir a desigualdade ............................................ 18

Quadro 3 - Funções econômicas do orçamento......................................................................... 20

Quadro 4 - Características dos bens públicos e privados ................................................................ 21

Quadro 5 - Funções econômicas do orçamento no federalismo fiscal.............................................. 26

Quadro 6 - Critérios para segregação de tributos no âmbito de uma Federação.............................. 27

Quadro 7 - Formas de repartição de recursos em um sistema de transferências ............................. 29

Quadro 8 - Estudos anteriores sobre desigualdades e instrumentos fiscais................................. 31

Quadro 9 - Relação entre o ônus e o pagamento do imposto............................................................. 36

Quadro 10 - Sistema tributário na CF/1988 atualizado........................................................ 42

Quadro 11 - Programas de transferências de renda relacionadas com a assistência social no âmbito da União entre 1995 e 2012.

Quadro 12 - Estudos quantitativos recentes sobre eficiência no setor público.............................. 48

Quadro 13 - Estatística Descritiva das Variáveis do Estudo ..................................................... 72

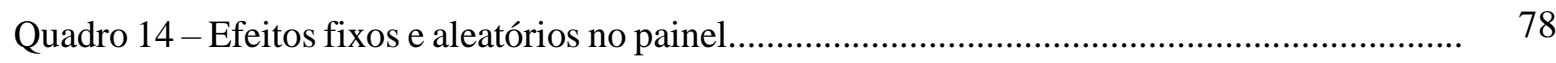

Quadro 15 - Testes a serem aplicados em um painel de MQO................................................... 79

Quadro 16 - Testes a serem aplicados em um painel tobit.................................................. 81

Quadro 17 - Parâmetros para avaliar a eficiência por DEA ....................................................... 83

Quadro 18 - Fronteiras da DEA quanto às propriedades de escala............................................. 85

Quadro 19 - Eixos da pesquisa, hipóteses e técnicas quantitativas............................................ 87

Quadro 20 - Descrição e sinal esperado das variáveis na hipótese 1 ............................................. 90

Quadro 21 - Descrição e sinal esperado das variáveis na hipótese 2 ............................................ 93

Quadro 22 - Descrição e sinal esperado das variáveis na hipótese 3 ........................................... 95 
Quadro 23 - Inputs e Outputs a serem utilizados nas hipóteses 4 e 5 - eficiência de custo e técnica.

Quadro 24 - Descrição e sinal esperado das variáveis nas hipóteses 4 e 5

Quadro 25 - Inputs e Outputs a serem utilizados na hipótese 6 - eficiência técnica

Quadro 26-Descrição e sinal esperado das variáveis na hipótese 6.

Quadro 27 - Resumos dos resultados obtidos na hipótese 1 - gastos por função

Quadro 28 - Resumos dos resultados obtidos na hipótese 1 - gastos por subfunção.

Quadro 29 - Benchmarkings de saúde resultantes da análise envoltória de dados (DEA) aplicados na hipótese 4 - modelo CCR

Quadro 30 - Benchmarkings de educação resultantes da análise envoltória de dados aplicados na hipótese 4 - modelo CCR

Quadro 31 - Benchmarkings de saúde resultantes da análise envoltória de dados aplicados na hipótese 5 - modelo CCR

Quadro 32 - Benchmarkings de educação resultantes da análise envoltória de dados aplicados na hipótese 5 - modelo CCR

Quadro 33 - Benchmarkings da arrecadação sobre a área territorial dos estados resultantes da análise envoltória de dados aplicados na hipótese 6 - modelo CCR.

Quadro 34 - Benchmarkings da arrecadação sobre frota de veículos automotores resultantes da análise envoltória de dados aplicados na hipótese 6 - modelo CCR 


\section{LISTA DE TABELAS}

Tabela 1 - Participação das regiões brasileiras no PIB nacional

Tabela 2 - População das regiões brasileiras

Tabela 3 - Percentual de pessoas na população total com renda domiciliar per capita inferior à linha de pobreza baseada em necessidades calóricas.

Tabela 4 - Percentual de pessoas na população total com renda domiciliar per capita inferior à linha de extrema pobreza baseada em necessidades calóricas

Tabela 5 - Evolução do coeficiente de Gini nas regiões do Brasil

Tabela 6 - Evolução do coeficiente de Theil-T nas regiões do Brasil.

Tabela 7 - Evolução da proporção da renda média entre os 10\% mais ricos e os $40 \%$ mais pobres

Tabela 8 - Evolução da proporção da renda média entre os $20 \%$ mais ricos e os $20 \%$ mais pobres

Tabela 9 - Variáveis, fontes de dados e limitações da hipótese 1

Tabela 10 - Variáveis, fontes de dados e limitações da hipótese 2

Tabela 11 - Variáveis, fontes de dados e limitações da hipótese 3

Tabela 12 - Variáveis, fontes de dados e limitações da hipótese 4

Tabela 13 - Variáveis, fontes de dados e limitações da hipótese 5

Tabela 14 - Variáveis, fontes de dados e limitações da hipótese 6.

Tabela 15 - Resultados da regressão de dados em painel com efeitos aleatórios: gastos estaduais

Tabela 16 - Resultados da regressão de dados em painel com efeitos aleatórios: gastos municipais

Tabela 17 - Resultados da regressão de dados em painel com efeitos aleatórios: gastos estaduais e municipais

Tabela 18 - Resultados da regressão tobit em painel: gastos estaduais

Tabela 19 - Resultados da regressão tobit em painel: gastos municipais

Tabela 20 - Resultados da regressão tobit em painel: gastos estaduais e municipais

Tabela 21 - Resultados da regressão de dados em painel com efeitos aleatórios: gastos estaduais por subfunção 
Tabela 22 - Resultados da regressão de dados em painel com efeitos aleatórios: gastos municipais por subfunção

Tabela 23 - Resultados da regressão de dados em painel com efeitos aleatórios: gastos estaduais e municipais por subfunção

Tabela 24 - Resultados da regressão tobit em Painel: gastos estaduais por subfunção.

Tabela 25 - Resultados da regressão tobit em Painel: gastos municipais por subfunção

Tabela 26 - Resultados da regressão tobit em Painel: gastos estaduais e municipais por subfunção

Tabela 27 - Resultados da regressão de dados em painel com efeitos aleatórios: impostos progressivos municipais 2001-2012.

Tabela 28 - Resultados da regressão tobit em painel: impostos progressivos municipais 20012012

Tabela 29 - Resultados da regressão de dados em painel com efeitos aleatórios: impostos progressivos estaduais 2001-2012...

Tabela 30 - Resultados da regressão tobit em Painel: impostos progressivos estaduais 20012012

Tabela 31 - Resultados da regressão de dados em painel com efeitos aleatórios: impostos progressivos federais 2001-2012.

Tabela 32 - Resultados da regressão tobit em Painel: impostos progressivos federais 20012012

Tabela 33 - Resultados da regressão de dados em painel com efeitos aleatórios: impostos progressivos de todas as esferas 2001-2012.

Tabela 34 - Resultados da regressão de dados em painel com efeitos aleatórios: impostos progressivos de todas as esferas 1995-2012.

Tabela 35 - Resultados da regressão tobit em Painel: impostos progressivos de todas as esferas 2001-2012.

Tabela 36 - Resultados da regressão tobit em Painel: impostos progressivos de todas as esferas 1995-2012.

Tabela 37 - Resultados da regressão de dados em painel com efeitos aleatórios: transferências de renda diretas 2004-2012.

Tabela 38 - Resultados da regressão tobit em Painel: transferências de renda diretas 2004-2012

Tabela 39 - Resultados da regressão dados painel com efeitos aleatórios: eficiência da função alocativa - ênfase nos produtos "ofertados" em saúde e educação 
Tabela 40 - Resultados da regressão tobit em painel: eficiência da função alocativa - ênfase nos produtos "ofertados" em saúde e educação

Tabela 41 - Resultados da regressão dados painel com efeitos aleatórios: eficiência da função alocativa - ênfase nos resultados alcançados em saúde e educação 2005-2012.

Tabela 42 - Resultados regressão tobit em painel: eficiência da função alocativa - ênfase nos resultados alcançados em saúde e educação 2005-2012

Tabela 43 - Resultados da regressão dados painel com efeitos aleatórios: eficiência da função alocativa - resultados alcançados em saúde.

Tabela 44 - Resultados da regressão tobit em painel: eficiência da função alocativa - resultados alcançados em saúde.

Tabela 45 - Resultados da regressão dados painel com efeitos aleatórios: eficiência da função distributiva - arrecadação de impostos progressivos 1998-2012.

Tabela 46 - Resultados da regressão tobit em painel: eficiência da função distributiva arrecadação de impostos progressivos1998-2012 


\section{SUMÁRIO}

1 INTRODUÇÃ

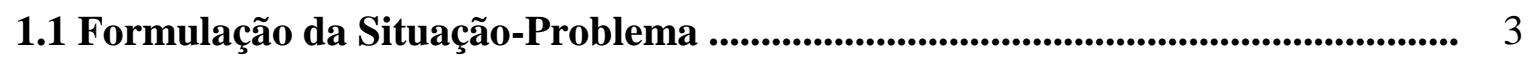

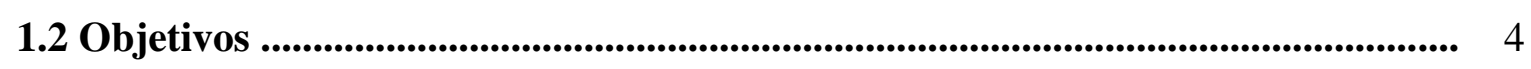

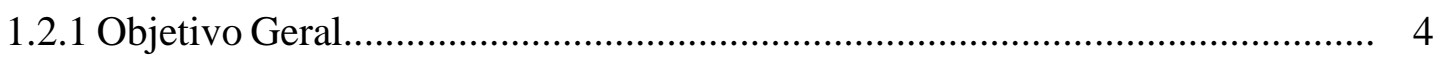

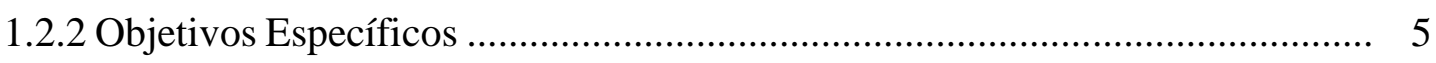

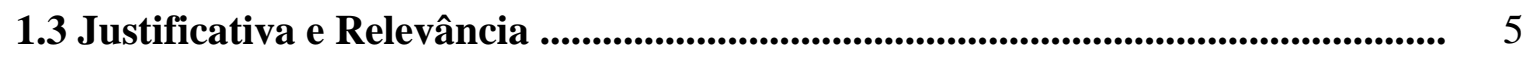

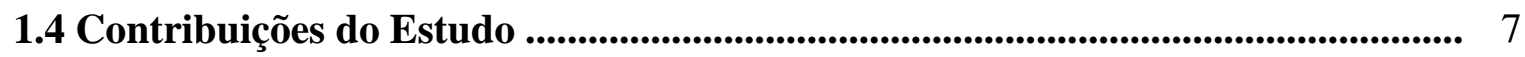

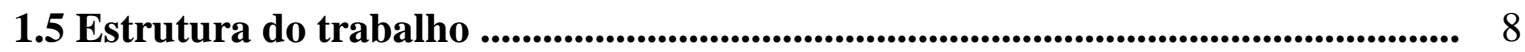

2 REFERENCIAL TEÓRICO _.............................................................................. 9

2.1 Formas de Mensurar a Desigualdade .................................................................................... 9

2.1.1 Dilemas na Mensuração da Desigualdade .................................................. 10

2.1.2 Métodos para Evidenciar a Desigualdade ................................................. 13

2.1.3 Propriedades das Medidas de Desigualdade ............................................ 17

2.2 Funções Econômicas do Orçamento..................................................................... 18

2.2.1 Função Orçamentária Alocativa ............................................................. 20

2.2.2 Função Orçamentária Distributiva......................................................... 22

2.2.3 Função Orçamentária Estabilizadora ...................................................... 23

2.3 Federalismo Fiscal e os Instrumentos Fiscais ................................................... 24

2.3.1 Impactos sobre as Funções Econômicas em uma Federação ........................... 24

2.3.2 Impactos sobre o Sistema Tributário ..................................................... 26

2.3.3 Impactos sobre o Sistema de Transferências de Recursos ............................ 27

2.4 Estado da Arte sobre os Efeitos das Funções Alocativa e Distributiva sobre as Desigualdades de Renda

2.4.1 Função Alocativa .................................................................................. 35

2.4.2 Função Distributiva................................................................................. 35

2.5 Peculiaridades dos Instrumentos Fiscais no Brasil .............................................. 38 
2.5.1 Despesas com Educação e Saúde.............................................................. 38

2.5.2 Receitas Coercitivas por Competência ..................................................... 41

2.5.3 Transferências de Renda Diretas ................................................................ 44

2.6 O Fator Eficiência ................................................................................................... 46

2.7 Breve Retrato sobre as Desigualdades no Brasil .................................................... 59

3 METODOLOGIA DA ANÁLISE EMPÍRICA _........................................... 63

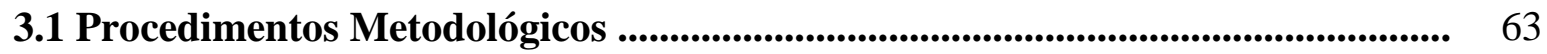

3.1.1 Sistema de Hipóteses ..................................................................... 63

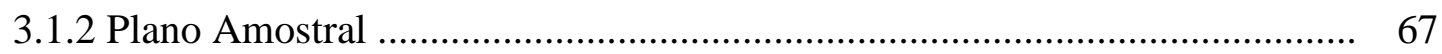

3.1.3 Estatística Descritiva das Variáveis......................................................... 72

3.1.4 Técnicas de Análise Quantitativa e seus Pressupostos ............................... 77

3.2 Modelagem Funcional e Econométrica das Hipóteses de Pesquisa ...................... 87

3.2.1 Modelo Econométrico Geral .................................................................. 88

3.2.2 Modelos do Eixo 1 - Hipótese 1 ......................................................... 88

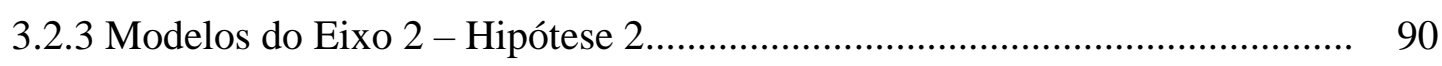

3.2.4 Modelos do Eixo 3 - Hipótese 3 ........................................................ 94

3.2.5 Modelos do Eixo 4 - Hipóteses 4 e 5 .................................................... 95

3.2.6 Modelos do Eixo 5 - Hipótese 6........................................................ 99

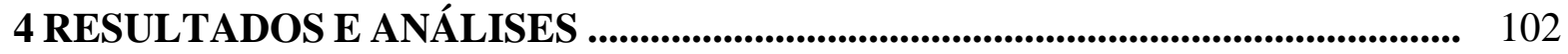

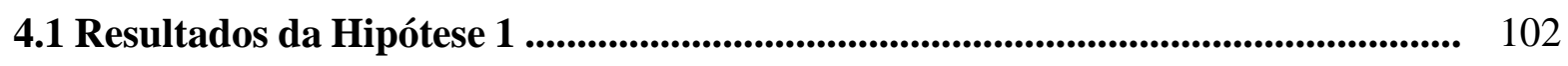

4.1.1 Gastos por Função da Despesa .......................................................... 102

4.1.2 Gastos por Subfunção da Despesa.............................................................. 106

4.2 Resultados da Hipótese 2 ................................................................................................. 112

4.2.1 Impacto dos Impostos Municipais ...................................................... 112

4.2.2 Impacto dos Impostos Estaduais..................................................... 114

4.2.3 Impacto dos Impostos Federais............................................................ 116

4.2.4 Impacto Simultâneo dos Impostos Progressivos ....................................... 117 
4.3 Resultados da Hipótese 3

4.4 Resultados da Hipótese 4 ............................................................................................. 122

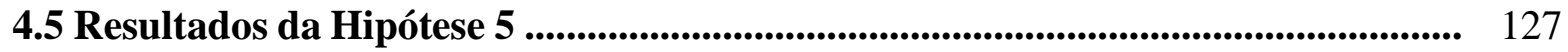

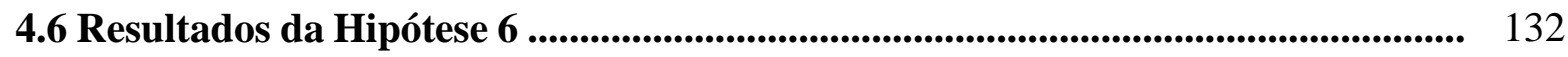

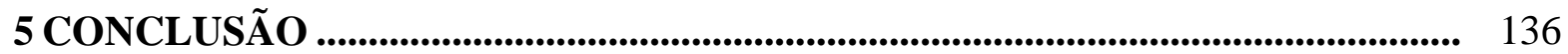

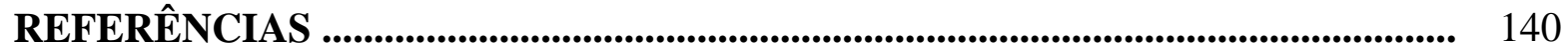




\section{INTRODUÇÃO}

Um dos problemas centrais no capitalismo moderno segundo a Escola Keynesiana seria a excessiva concentração de renda e riqueza que separa as classes sociais. A concentração excessiva dificultaria a manutenção do pleno emprego nas economias modernas, porque os ricos, que se beneficiariam da concentração, consumiriam relativamente pouco em proporção à sua renda, enquanto os pobres, que consumiriam proporcionalmente mais, seriam privados dessa possibilidade. $\mathrm{O}$ resultado seria uma demanda total por bens de consumo mais fraca, o que desestimularia a produção de bens de consumo e, indiretamente, a produção de bens de investimento. Além disso, a concentração de renda excessiva prejudicaria a legitimidade do capitalismo, pois criaria grupos sociais que usufruiriam da riqueza social sem terem contribuído para sua criação (KEYNES, 1996; CARVALHO, 2008).

A solução para esse problema, argumentavam os keynesianistas, repousava principalmente na promoção de mudanças institucionais, como a introdução de impostos progressivos e impostos sobre capital, especialmente, sobre heranças. A política econômica poderia ajudar, mas não seria particularmente potente para esse fim (KEYNES, 1996; CARVALHO, 2008).

Mais recente, em setembro de 2000, 189 nações firmaram um compromisso para combater a extrema pobreza e outros males da sociedade. Esta promessa acabou se concretizando nos 8 Objetivos de Desenvolvimento do Milênio ${ }^{1}$ (ODM) que deveriam ser alcançados até 2015 (ONU, 2000). Em setembro de 2010, o mundo renovou o compromisso para acelerar o progresso em direção ao cumprimento desses objetivos.

Ao final de 2014, foi evidenciado em relatório da Organização das Nações Unidas (ONU) que no período de 2000 a 2010 o Brasil diminuiu a desigualdade entre as regiões metropolitanas, principalmente entre o Norte e o Sul. A diferença entre São Paulo, com o maior Índice de Desenvolvimento Humano Municipal (IDHM), e Manaus, na pior colocação, que era de 22,1\% em 2000, caiu para 10,3\% em 2010 (Objetivos de Desenvolvimento do Milênio, 2014).

\footnotetext{
${ }^{1}$ Reduzir da pobreza; atingir o ensino básico universal; igualdade entre os sexos e a autonomia das mulheres; reduzir a mortalidade na infância; melhorar a saúde materna; combater o HIV/Aids, a malária e outras doenças; garantir a sustentabilidade ambiental; estabelecer uma parceria mundial para o desenvolvimento.
} 
Um dos resultados positivos constantes no relatório é que nenhuma das unidades ficou com o desenvolvimento muito baixo; porém, um dos resultados negativos é que persistem as desigualdades dentro das regiões metropolitanas, mesmo considerando o extraordinário progresso obtido (Objetivos de Desenvolvimento do Milênio, 2014).

Realizando uma análise mais detida sobre resultados negativos, a primeira conclusão é que não há nenhuma novidade ou surpresa. Paes e Siqueira (2008) já afirmavam que um dos grandes paradoxos da atualidade é a coexistência de economias extremamente desenvolvidas em meio a enormes bolsões de pobreza. Isto acontece tanto entre países de um mesmo continente quanto entre regiões de um mesmo país. A distribuição da renda per capita de cada um destes dois polos parece exibir um padrão persistente: os extremos parecem divergir uns dos outros, com os pobres se tornando cada vez mais pobres e os ricos mais ricos.

Retomando a discussão sobre as possíveis soluções para combater a excessiva concentração de renda e de riqueza que separa as classes sociais e acentuam a desigualdade, Musgrave e Musgrave (1980) propuseram três funções econômicas do orçamento moderno: função distributiva que se propõe a promover o ajustamento na distribuição da renda e ofertar bens e serviços para a população menos assistida ou em situação de pobreza; a função alocativa que busca promover ajustamentos na alocação de recursos; e a função estabilizadora que busca promover a manutenção da estabilidade econômica. Observa-se que das três funções, a função que busca primordialmente utilizar a política orçamentária para reduzir as desigualdades é a função distributiva, em que pese as demais funções contribuírem também para o alcance deste objetivo.

Os estudos contemporâneos sobre desigualdade têm como uma de suas referências o trabalho de Simon Kuznets: Economic Growth and Income Inequality. Kuznets (1955) utilizou um modelo dual com um setor agrícola e outro não agrícola - moderno e dinâmico - com o intuito de analisar a relação entre desigualdade de renda e o crescimento econômico. O resultado é o de que a desigualdade de renda se elevaria no curto prazo e, com o crescimento econômico reduzir-se-ia, configurando um U invertido. Dessa forma, passou-se a assumir a hipótese de que os países com baixo grau de desenvolvimento tenderiam a verificar maior nível de desigualdade de renda a curto prazo e que tal relação tenderia a se reverter à medida que tais países galgassem as etapas necessárias para atingir níveis mais elevados de renda per capita. 
Em que pesem as conclusões do estudo de Kuznets (1955), que estão mais aderentes à função estabilizadora relacionada ao crescimento econômico, este trabalho estuda apenas as funções orçamentárias alocativa e distributiva, e suas relações com a desigualdade de renda.

\subsection{Formulação da problemática da pesquisa}

A literatura sobre desigualdade de renda e gasto público é vasta tanto no âmbito internacional, quanto nacional.

Estudos de Perotti (1992), Meltzer e Richard (1993), Easterly e Rabelo (1993), Lindert (1996), Perroti (1996), Gouveia e Masia (1998), Bassett, Burkett e Putterman (1999), Rodriguez (1999), Tanninen (1999), Panizza (1999), Castronova (2001), Jha, Biswal e Biswal (2001), Sylwester (2002), De Mello e Tiongson (2006), Bergh e Fink (2008), Zhang (2008), Holzner (2011) e Araújo, Alves e Bessaria (2013) utilizaram gastos públicos, elementos da função alocativa, como tentativa de avaliar seu respectivo impacto sobre a desigualdade de renda.

Já os estudos de Perroti (1994), Persson e Tabellini (1994), Perroti (1996), Partridge (1997), Figini (1998), Panizza (1999), Rocha (2004, 2008b, 2008b), De Mello e Tiongson (2006), Kakwani, Neri e Son (2006), Medeiros, Brito e Soares (2007), Costa, Savato e Diniz (2008), Ferraz (2008), Tavares et ali (2009), Kerstenetzky (2009), Hoffmann (2010), Marinho, Linhares, Campelo (2011), Marinho, Linhares e Campelo (2011), Cavalcanti, Costa e Silva (2013), Araújo, Alves e Besarria (2013), Lima, Moreira e Souza (2013), Lima e Moreira (2014), Vaz (2013), Peña et alli (2015) utilizaram transferências ou impostos, elementos da função distributiva, como tentativa de avaliar seu respectivo impacto sobre a desigualdade de renda.

Quanto à função estabilizadora, Easterly e Fischer (2001), Ghura, Leite e Tsangarides (2002), Meschi e Vivarelli (2009) concordam que a inflação traz consequências negativas para a desigualdade, enquanto Gunter, Cohen e Lofgren (2005) não encontraram resultados significativos que indicassem redução da pobreza nos períodos de estabilidade macroeconômica. 
Um fator importante nas pesquisas, consiste na definição da variável utilizada para aferir a desigualdade. Os trabalhos de Easterly e Rabelo (1993), Figini (1998), Tanninen (1999), Garuda (2000), Sylwester (2002), Thorbecke e Charumilind (2002), Rocha (2004, 2008b, 2008b), De Mello e Tiongson (2006), Bergh e Fink (2008), Zhang (2008), Oliveira, Zabot e Schneider (2009), Hoffmann (2010), Holzner (2011), Marinho, Linhares e Campelo (2011), Oberdabernig (2013), Araújo, Alves e Besarria (2013), Ali, Fjeldstad e Sjursen (2014), Christiaensen e Todo (2014), Cingano (2014), Lima, Moreira e Souza (2013), Lima e Moreira (2014), Hassine (2015), Peña et alli (2015) utilizaram o coeficiente de Gini.

O coeficiente de Theil-T foi utilizado nos estudos de Rocha (2008a), Araújo, Alves e Besarria (2013) e Peña et alli (2015).

O Q3 (proporção da receita auferida pelo $3^{\circ}$ quintil da população: quanto maior a proporção, menor a desigualdade) foi utilizado nos estudos de Perotti (1992, 1994, 1996), Persson e Tabellini (1994), Partridge (1997), Bassett, Burkett e Putterman (1999), Panizza (1999); enquanto o Q5 (quinto quintil) foi utilizado por Garuda (2000).

Considerando os estudos anteriores, tem-se a seguinte questão da pesquisa: Qual é o efeito da função orçamentária alocativa e da função orçamentária distributiva sobre a desigualdade de renda nos Estados do Brasil entre 1995 e 2012 ?

Quanto à função alocativa foram selecionados os gastos com saúde e educação, pois de acordo com Musgrave e demais estudos citados geram externalidades positivas. Quanto à função distributiva foram selecionados os impostos progressivos e as transferências de renda direta.

Ressalta-se que os Estados do Brasil serão avaliados sob o aspecto geográfico, uma vez que serão consideradas variáveis incidentes sobre a população do território estadual, mas que dependem de iniciativa do governo federal e dos governos municipais, além das iniciativas dos próprios governos estaduais.

\subsection{Objetivos de Pesquisa}

\subsubsection{Objetivo geral}

O objetivo do estudo é avaliar os impactos dos instrumentos fiscais representados pelas funções orçamentárias alocativa e distributiva sobre a desigualdade de renda nos Estados do Brasil entre 1995 e 2012.

Este estudo utilizou um sistema composto de seis hipóteses que possibilitaram o alcance do objetivo a serem apresentadas ao longo do referencial teórico. 


\subsubsection{Objetivos específicos}

Para atingir o objetivo geral foi necessário realizar os seguintes objetivos específicos:

(i) Explorar a literatura referente à desigualdade buscando selecionar as variáveis mais representativas para mensurar o fenômeno;

(ii) Explorar a literatura referente à função alocativa e distributiva no orçamento buscando selecionar as variáveis mais representativas para mensurar o fenômeno;

(iii) Identificar a modelagem quantitativa apropriada para testar as hipóteses a serem estabelecidas, que serão orientadas pela mensuração da relação entre instrumentos fiscais e desigualdade de renda.

\subsection{Justificativa e Relevância}

Holzner (2011) afirma que dependendo do nível e tipos de gastos públicos, diferentes resultados podem ser alcançados pelos instrumentos fiscais no combate às desigualdades de renda: tanto um cenário com elevado gasto público e baixa desigualdade, quanto um cenário como variações opostas.

Melo e Tiongson (2006) consideram que a desigualdade é uma questão estrutural e que a desigualdade de hoje depende da desigualdade de ontem. Em primeiro lugar, os autores entendem que os governos nas sociedades mais desiguais são menos propensos a gastar em programas redistributivos. Em segundo lugar, os gastos redistributivos podem ser ineficientes como instrumento para reduzir a pobreza e melhorar a distribuição de renda, porque os benefícios da despesa pública podem ser capturados pelos "não pobres". Para os autores, quando os gastos distributivos não são bem orientados, os indicadores de distribuição de renda podem não ser sensíveis aos respectivos aumentos de gastos públicos em programas redistributivos.

Estudos de De Mello e Tiongson (2006), Rocha (2008a), Bergh e Fink (2008), Zhang (2008), Hoffmann (2010), Holzner (2011), Araújo, Alves e Bessaria (2013), Cavalcanti, Costa e Silva (2013), Peña et ali (2015) evidenciaram que os gastos distributivos apresentam capacidade para reduzir as desigualdades. Assim, este estudo de justifica inicialmente pela necessidade de avaliar o comportamento dos estados brasileiros quanto aos efeitos das funções alocativa e distributiva sobre a desigualdade de renda. 
Outro pilar que justifica esse estudo é a inclusão do fator eficiência na análise. Mendes (2006) argumenta que no modelo de Estado brasileiro, criado a partir da redemocratização de 1984 e da Constituição de 1988, a qualidade dos serviços prestados é baixa e os custos gerados pelas falhas de governo ${ }^{2}$ são significativos.

Segundo o autor, a súbita elevação de recursos disponíveis nas mãos de administrações municipais com baixa qualificação técnica, em comunidades dotadas de frágeis mecanismos de controle da ação pública, deixou espaço para muita ineficiência, corrupção e captura de recursos públicos.

No âmbito internacional, destacam-se na última década os seguintes estudos quantitativos sobre avaliação da eficiência no setor público: Afonso e Aubyn (2005), Afonso, Schuknecht e Tanzi (2005), Herrera e Pang (2005), Sutherland, Price, Joumard e Nicq (2006), Ribeiro e Rodrigues Júnior (2006), Mandl, Dierx e Ilzkovitz (2008), Schwellnus (2009), Wang e Alvi (2011) e Grigoli (2014).

No âmbito nacional, destacam-se na última década os seguintes estudos quantitativos sobre avaliação da eficiência no setor público: Sousa, Cribari-Neto e Stosic (2005), Souza Júnior e Gasparini (2006), Miranda (2006), Brunet, Borges e Bertê (2006), Postali e Rocha (2009), Costa (2013), Costa et ali (2015).

Em que pese a relevância dos achados dos estudos anteriores, apenas o estudo de Herrera e Pang (2005) trabalhou com os dados de forma dinâmica (considerando diversas unidades de decisão em diversos períodos de tempo). Os demais estudos, devido ao uso de modelos específicos de análise envoltória de dados (DEA), mais especificamente os modelos de Charnes, Cooper e Rhodes (1978) e de Banker, Charnes e Cooper (1984), trabalharam com cortes transversais.

\footnotetext{
${ }^{2}$ Em primeiro lugar, o setor público tem menos incentivos que o privado para minimizar custos e buscar maior qualidade. Em segundo lugar, os políticos e burocratas que operam a máquina estatal podem utilizar o poder de que dispõem para extrair rendas em favor próprio ou de grupos sociais. Isso aumenta o custo e reduz a qualidade dos serviços públicos. Em terceiro lugar, o processo político de decisão coletiva sobre as ações do Estado pode resultar em despesas públicas elevadas, exigindo alta tributação e endividamento públicos, provocando um crowding-out do investimento privado e comprometendo o equilíbrio de preços e o crescimento econômico. Em quarto lugar, as ações públicas dependem de leis que determinam a sua execução. Dado que a aprovação de leis é um processo lento, o setor público tende a ser menos ágil que o privado nas correções de rumos e ajustes de metas, bem como está sujeito a perpetuação de privilégios inscritos em lei (MENDES, 2006).
} 
Observou-se nos três parágrafos anteriores que entes nacionais ou subnacionais tiveram sua eficiência aferida sob algum aspecto (geralmente aspectos relacionados à saúde ou educação), porém esses escores de eficiência não foram utilizados em um segundo momento para aferir seus potenciais efeitos sobre as desigualdades, uma das lacunas a serem preenchidas neste estudo.

Assim, o atual estudo justifica-se (i) pela existência de um problema social: a desigualdade de renda; (ii) pela necessidade de aferir o impacto dos instrumentos fiscais sobre as desigualdades, considerando as peculiaridades do federalismo fiscal brasileiro; (iii) pela inserção do fator eficiência na análise da desigualdade de renda.

\subsection{Contribuições do estudo}

A seguir, constam os principais avanços que o trabalho apresenta em relação ao tema em foco:

-Considera um período de relativa estabilidade: o plano real de 1995 a 2012.

-Identifica quais gastos e quais impostos devem ser incrementados na redução da desigualdade de renda.

-Identifica quais Estados são mais eficientes na alocação de recursos públicos em saúde e educação e na arrecadação de impostos e seu respectivo efeito na redução da desigualdade de renda.

-No caso da hipótese 1, o trabalho considera as subfunções da despesa no mesmo período, fato não observado em trabalhos nacionais anteriores;

-No caso da hipótese 1, são consideradas três perspectivas de gastos: estaduais; municipais; estaduais e municipais;

- No caso da hipótese 2, considera todos os impostos federativos progressivos, fato não observado em pesquisas anteriores.

- No caso da hipótese 3, considera além do Bolsa Família, o BPC (Benefício de Prestação Continuada) idoso e o BPC deficiente, fato pouco usual em pesquisas anteriores.

-Nas hipóteses 4, 5 e 6, o trabalho combina em um $1^{\circ}$ estágio a DEA e em um segundo estágio: análise dados em painel com efeitos aleatórios e regressão tobit em painel. 


\subsection{Estrutura do trabalho}

O estudo está estruturado em cinco partes além desta introdução: referencial teórico; metodologia da análise empírica; apresentação de resultados com as respectivas análises; conclusão e referências.

No referencial teórico serão apresentados inicialmente os conceitos sobe a desigualdade e as funções econômicas do orçamento. Na sequência, serão apresentados estudos recentes dos efeitos das funções alocativa e distributiva sobre a desigualdade de renda. Posteriormente, serão apresentados os elementos estruturantes do federalismo fiscal, com a inclusão de peculiaridades do caso brasileiro, e que terão impacto direto sobre as hipóteses de pesquisa formuladas. Por fim, será inserido o fator eficiência que se constitui em uma das inovações deste estudo. Considerando que este estudo utiliza a abordagem hipotético-dedutiva, as hipóteses serão enunciadas em um primeiro momento no referencial teórico e em um segundo momento na metodologia.

A metodologia da análise empírica contém os procedimentos metodológicos e os modelos funcionais e empíricos relacionados às hipóteses enunciadas no tópico do referencial. Nos procedimentos metodológicos serão apresentados o sistema de seis hipóteses e as fontes de obtenção dos dados das variáveis, bem como serão descritos os métodos quantitativos utilizados: painel métodos quadrados ordinários (MQO) com efeitos aleatórios, regressão tobit em painel e análise envoltória de dados (DEA).

$\mathrm{Na}$ apresentação dos resultados constam os achados, obtidos a partir da aplicação dos testes para seis hipóteses de pesquisa; enquanto na conclusão constam os entendimentos obtidos do estudo. 


\section{REFERENCIAL TEÓRICO}

\subsection{Formas de mensurar a desigualdade}

A desigualdade não é um fato natural, mas sim uma construção social. Ela depende de circunstancias e é, em grande parte, o resultado das escolhas políticas feitas ao longo da história de cada sociedade (SCALON, 2011). Todas as sociedades experimentam desigualdades e estas se apresentam de diversas formas: como prestígio, poder, renda, entre outras - e suas origens são tão variadas quanto suas manifestações. O desafio não é apenas descrever os fatores e componentes das desigualdades sociais, mas também explicar sua permanência, e em alguns casos seu aprofundamento, apesar dos valores igualitários modernos (SCALON, 2011).

Segundo Cowell (2011) a igualdade ou desigualdade pode-se ser interpretada de formas distintas, as quais constam na Figura 1.

Figura 1 - Formas de mensurar a desigualdade.

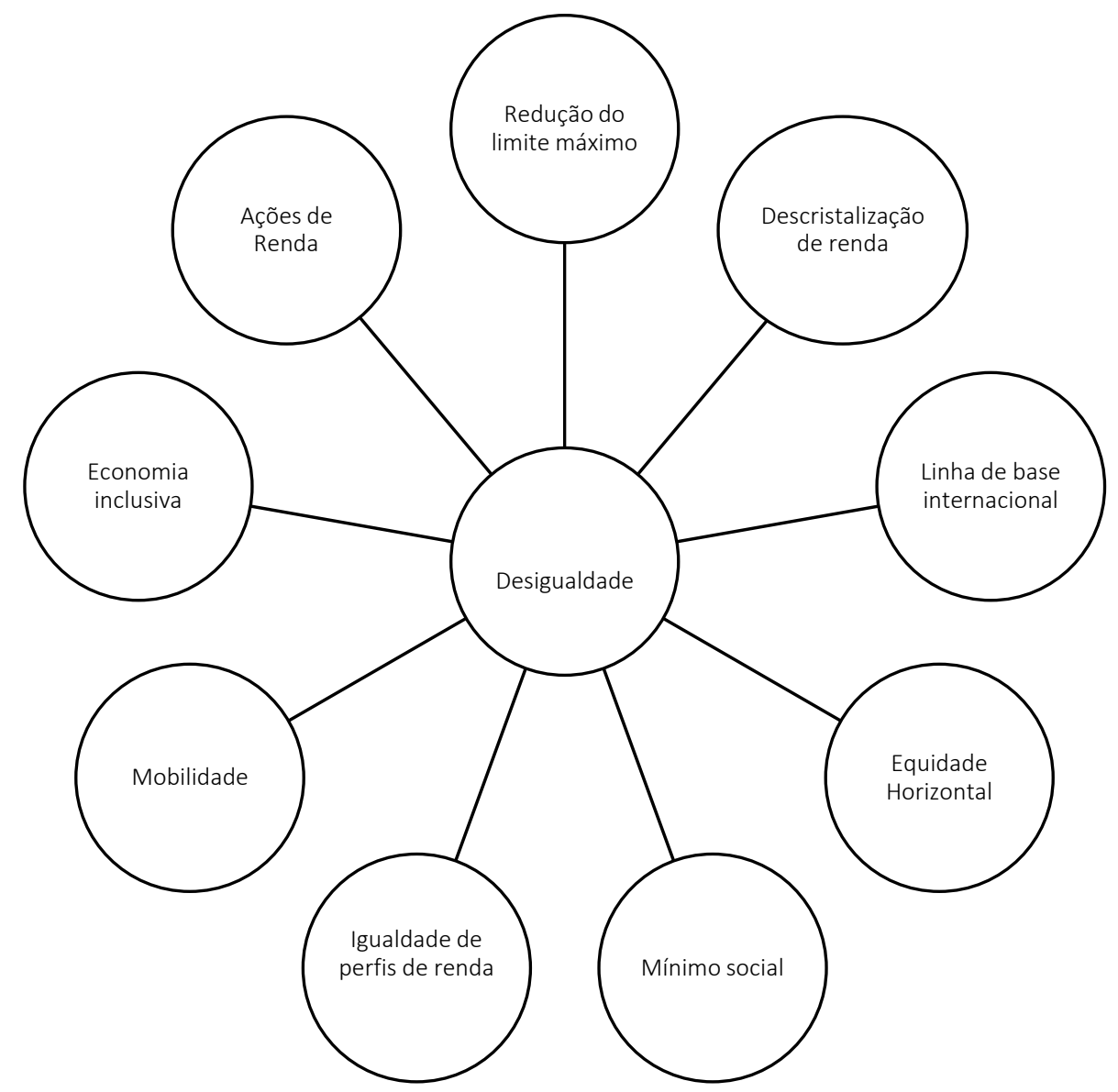

Fonte: Adaptado de Cowell (2011) 
A equidade horizontal consiste em tratar os iguais com igualdade. O mínimo social visa garantir que todos tenham um padrão mínimo de bem-estar. A igualdade de perfis de renda vitalícia se concentra na redução da desigualdade de rendas perspectivas futuras. A mobilidade visa reduzir barreiras entre grupos ocupacionais permitindo a ascensão social. A economia inclusiva visa reduzir ou eliminar a sensação de exclusão da sociedade causada por diferenças da renda ou algum outro fator. As ações de renda têm como objetivo aumentar a parcela da renda nacional auferida por um grupo relativamente desfavorecido. A redução do limite máximo visa limitar a quota de recursos auferidos pela parcela mais favorecida da população. A descristalização da riqueza e renda visa eliminar as vantagens desproporcionais na educação, no poder político, na aceitabilidade social que possam ser vinculadas a uma vantagem (desvantagem) no rendimento ou riqueza. A linha de base internacional busca que a nação objeto de avaliação não deve ser mais desigual do que outra nação comparável (COWELL, 2011).

Além disso, Cowell (2011) incorpora elementos adicionais na mensuração da desigualdade: (i) especificação da unidade social de medida: individual, a família nuclear ou a família alargada; (ii) descrição do atributo da variável dependente: renda, riqueza, propriedade de terra, poder de voto, etc.; (iii) método de representação ou agregação de destinação do lucro entre as pessoas em uma determinada população.

Por fim, duas características fundamentais do índice de desigualdade são: mensurabilidade e comparabilidade entre diferentes pessoas (COWELL, 2011).

\subsubsection{Dilemas na mensuração da desigualdade}

O processo de mensuração das desigualdades exige que alguns parâmetros sejam definidos. Cowell (2011) define dois: a unidade social e o atributo de desigualdade. A unidade social pode ser discriminada com individual, família nuclear ou família alargada, enquanto o atributo pode ser a renda, a riqueza, a propriedade de terra, ou o poder de voto. Cowell (2011) sugere que se use o indivíduo e a renda como parâmetros. Este estudo considerará essa sugestão, porém incorporará elementos relacionados ao patrimônio e heranças.

Outro dilema importante ao se mensurar a desigualdade ocorre quando se utilizam medidas simultâneas de desigualdade para diagnosticar uma mesma população. A Figura 2 ilustra a situação. 
Figura 2 - Relação entre medidas simultâneas de desigualdade.

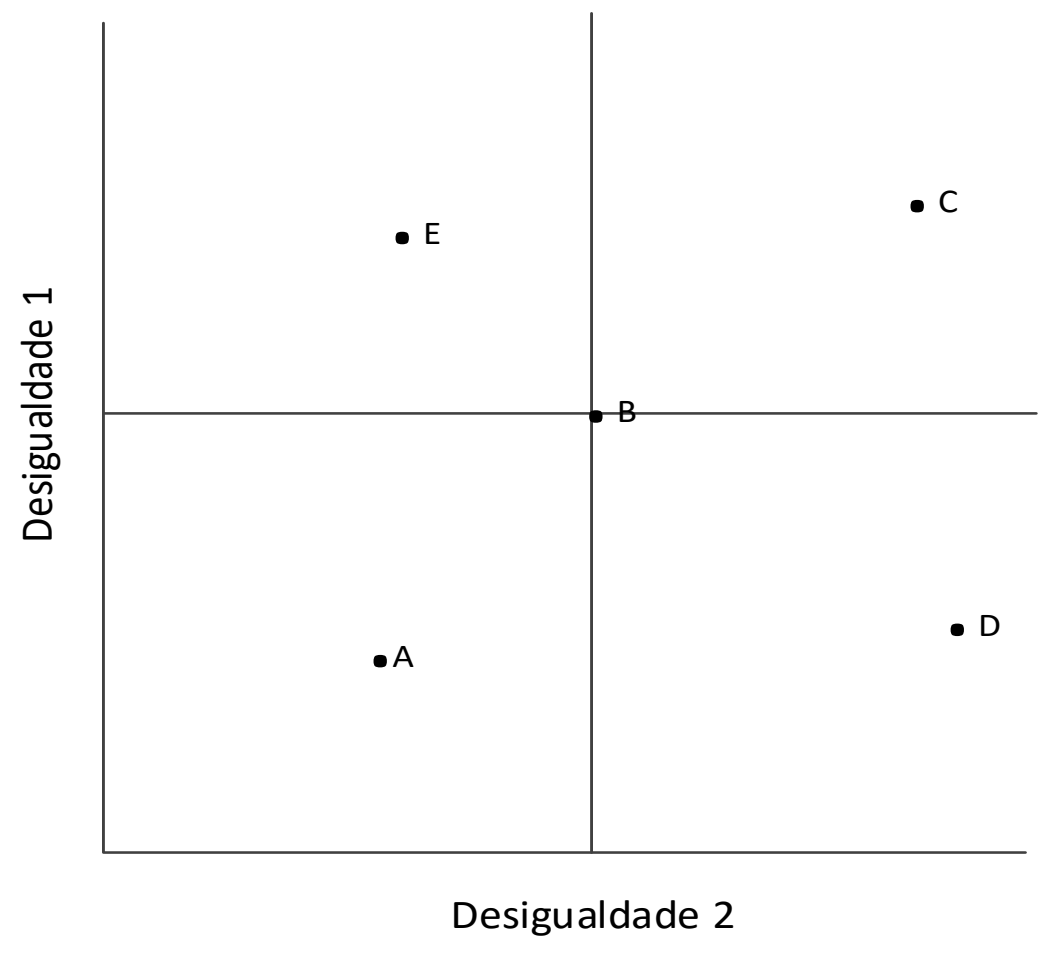

Fonte: Cowell (2011).

Podemos afirmar com certeza que o ponto A é menos desigual que o ponto C. Mas o que dizer do ponto E em relação ao ponto D? Qual dos dois é menos desigual? Dependendo da perspectiva, a análise pode ser relativizada.

O próximo dilema diz respeito à mobilidade social. Segundo Cowell (2011) a suposição comum é que se a estrutura geral das diferenças de renda permanece a mesma, a desigualdade medida permanece inalterada, ou seja, se há uma migração de pessoas da classe menos favorecida para uma classe intermediária, mas a quantidade de pessoas da classe mais favorecida permanece inalterada, ainda há desigualdade, embora possa se argumentar que esta migração possui relação com a desigualdade de oportunidades.

O dilema seguinte é a relação entre o indicador da extensão da pobreza e a medida de desigualdade econômica. Normalmente esses dois problemas distintos estão relacionados. No caso da medição da pobreza, busca-se identificar o segmento da população abaixo de alguma linha de pobreza. No caso de uma desigualdade geralmente deseja-se capturar os efeitos das diferenças de renda em uma faixa muito mais ampla. Por isso, é perfeitamente possível a extensão de medição da pobreza estar diminuindo ao longo do tempo, e, ao mesmo tempo e na mesma sociedade a desigualdade estar aumentando (COWELL, 2011). 
Neste sentido, extrapolando esse raciocínio, se hipoteticamente toda uma população vive na miséria e no mesmo nível de miséria então não há desigualdade, mas há pobreza. Por outro lado, se um país é formado por pessoas ricas e também muito ricas, então não há pobreza mas há desigualdade. Dessa forma, pode-se diminuir a pobreza, sem alterar a desigualdade.

Cowell (2011) não descarta o uso da extensão da pobreza como forma de aferir a desigualdade, mas não pode ser a única medida. Este estudo considera as duas perspectivas.

Por fim, um outro dilema diz respeito a forma de obtenção dos dados sobre a riqueza. Existem dois métodos: o voluntário e o compulsório. O método voluntário, envolve a construção de uma amostra da população sobre a qual será aplicada um questionário solicitando informações sobre rendimento, patrimônio, tipos de ativos de exploração, padrões de gastos, composição do agregado familiar, etc. Este método é usado na Pesquisa Familiar do Reino Unido e nos levantamentos anuais do Escritório Census dos EUA. Uma desvantagem é a não-resposta que pode enviesar a amostra. Uma das vantagens é que quando uma pessoa é voluntária para participar de uma pesquisa, pode-se obter informações muito mais detalhadas e diversificadas do que ocorreria por intermédio do método compulsório (COWELL, 2011).

Nos métodos compulsórios, as informações sobre a renda e riqueza podem ser obtidas pelas declarações fiscais. Dentre as vantagens, destacam-se: (i) possibilidade de se obter uma amostra maior e mais representativa da população; e (ii) redução dos nãorespondentes devido a existência das penalidades legais quando da não declaração consistente. Uma das desvantagens decorre da não captura de toda a renda e riqueza na declaração fiscal, visto que tanto os ricos quanto os "não tão ricos" adotam medidas legais para evitar o imposto através da transformação de alguma parte de sua renda em formas não tributáveis (COWELL, 2011). 


\subsubsection{Métodos para evidenciar a desigualdade}

Os métodos para evidenciar a informação sobre a desigualdade de renda podem ser agrupados em dois grupos: diagramas e medidas de desigualdade (COWELL, 2011). O Quadro 1 mostra os grupos e os respectivos elementos.

Quadro 1 - Métodos para evidenciar a desigualdade de renda

\begin{tabular}{|l|l|}
\hline \multicolumn{1}{|c|}{ Diagramas } & \multicolumn{1}{c|}{ Medidas de Desigualdade } \\
\hline -Parada de Pen. & -Amplitude Total. \\
-Curva de Lorenz. & -Desvio Médio Relativo. \\
-Curva de Lorenz Generalizada. & -Variância. \\
-Curva de Concentração. & -Coeficiente de Gini. \\
-Transformação Logarítmica. & -Coeficiente de Atkinson. \\
& -Coeficiente de Theil-T. \\
& -Variância logarítmica. \\
\hline
\end{tabular}

Fonte: Medeiros (2006), Cowell (2011).

\subsubsection{Diagramas}

A Parada de Pen é uma metáfora extremamente criativa e simples usada para descrever uma distribuição de renda. Nela, a desigualdade de rendimentos é associada à desigualdade na altura das pessoas. Esse recurso chama atenção para o fato de que se a altura das pessoas fosse proporcional a suas rendas, se viveria em uma sociedade formada por uma grande massa de anões e uma pequena elite de gigantes (MEDEIROS, 2006).

A Curva de Lorenz é uma construção simples que indica quanto cada fração da população detém da renda total. Ela é muito útil, dentre outras coisas, porque facilita comparações de distribuições entre populações com níveis de riqueza diferentes ou das distribuições de uma mesma população entre distintos momentos no tempo (MEDEIROS, 2006).

A Curva de Lorenz Generalizada é uma modificação da Curva de Lorenz que traz informações sobre a forma e o nível da distribuição, tal como a Curva de Quantis. Tratase de uma ferramenta extremamente útil para comparar níveis de bem-estar de diferentes distribuições sem que a comparação seja afetada pelo tamanho da populaçõão. Ela é um dos principais instrumentos usados em análise de dominância de bem-estar entre distribuições (MEDEIROS, 2006). 
Uma Curva de Concentração é uma das formas de representação gráfica da concentração de algo segundo grupos ou indivíduos. As Curvas de Concentração têm várias aplicações, como o estudo da progressividade da distribuição de serviços públicos segundo grupos de renda ou a análise da distribuição dos componentes da renda total das famílias (MEDEIROS, 2006).

A Transformação Logarítmica corrige um problema quando se utiliza distribuições de frequência com dados de renda absolutos, uma vez que rendas muito elevadas podem distorcer o diagrama. Assim, ao ajustar a renda para função logarítmica esse problema é corrigido (MEDEIROS, 2006; COWELL, 2011).

\subsubsection{Medidas de Desigualdade}

\subsection{Amplitude Total}

A amplitude total - AT é igual a diferença entre o maior e menor valor de renda tal qual consta na equação 1 .

Amplitude Total $=$ Renda Máxima - Renda Mínima

Este valor pode ser calculado em termos absolutos ou relativos. Sua aplicação em populações grandes está bastante restrita, ainda mais quando estas são heterogêneas e quando os valores mínimos e máximos podem ser apenas estimados. Por fim, a amplitude total não capta a estrutura da distribuição, que seria uma das funções principais de uma medida de desigualdade (COWELL, 2011).

\subsection{Desvio Médio}

O desvio médio (DM) é baseado na diferença absoluta entre cada renda e a renda média, relacionada à renda média conforme consta na equação 2.

$$
\text { Desvio Médio }=\sum \frac{(\text { Renda } i-\text { Renda Média })}{\text { Renda Média }}
$$

Quanto maior o DM, maior é a desigualdade. A aplicação do desvio médio como medida de variação é restrita, em razão do uso de valores absolutos. A fraqueza desta medida está no fato que qualquer redistribuição de renda que ocorra dentro do segmento abaixo da média (o mesmo vale para as rendas acima da média) deixa DM inalterado (COWELL, 2011). 


\subsection{Variância}

A variância é a medida dos quadrados dos desvios em relação à média da distribuição (COWELL, 2011).

$$
S^{2}=\sum \frac{(\text { Renda } i-\text { Renda Média })^{2}}{\text { Renda Média }}
$$

\subsection{Coeficiente de Gini}

O índice de Gini, desenvolvido por Corrado Gini em 1914, é uma das principais medidas de desigualdade. O índice tem uma associação direta com a curva de Lorenz, já que seus valores correspondem ao cálculo da área entre a reta da igualdade e a curva de Lorenz (HOFFMAN, 1998). O índice é assim construído: os dados da população são organizados de acordo com a renda crescente. A população é agrupada em quantis (ou quintis, ou decis). Para cada uma destas classes, é levantada a renda média. A partir destes dados absolutos são calculadas, as respectivas percentagens que cada quantil tem na distribuição de renda. Em seguida, são computadas as frequências acumuladas, obtendose, assim, uma distribuição que permite relacionar para cada quantil agregado da população sequencialmente as respectivas parcelas acumuladas da renda (SPANGER, 2003, 2008). A equação 4 contém a fórmula.

$$
G=1-\sum \frac{\left(\varnothing+\emptyset_{i-1}\right)}{n}
$$

Sendo que $i=1,2,3, \ldots, n$ e que $\emptyset=\sum \frac{x_{i}}{n \times z}$, em que $z=$ renda média. Uma das críticas referente ao uso do índice de Gini reside no fato de que as transferências de renda, do mesmo valor, entre duas pessoas, impactam de forma mais expressiva no valor de G, se estas pessoas estão localizadas no meio da distribuição e não num dos dois extremos (SPANGER, 2003, 2008; COWELL, 2011).

\subsection{Coeficiente de Atkinson}

Atkinson (1975), desenvolveu um conjunto de índices que incorporam na sua medida julgamentos normativos de uma função de bem-estar. O autor admite que o nível de bem-estar social W é uma função aditivamente separável e simétrica das rendas individuais (HOFFMANN, 1998).

Considerando uma população com $\mathrm{n}$ pessoas, o bem-estar destas pessoas é definido como: 
Assim, sendo $\mathrm{U}\left(\mathrm{y}_{\mathrm{i}}\right)$ o bem-estar que a sociedade associa à renda da enésima pessoa, W seria então uma função aditiva das rendas individuais. Para criar sua medida de desigualdade Atkinson (1975) introduziu o conceito de nível de renda equivalente numa distribuição igualitária (ỹ) (HOFFMANN, 1998).

Seja $\mu$ a renda média de uma população com n pessoas:

$\mu=\frac{1}{n} \sum y_{i} ; i=1, \ldots, n$

Em que o nível de renda equivalente em uma distribuição igualitária (ỹ) seria o valor da renda que cada pessoa deveria receber, com todos recebendo renda igual, para que o nível de bem-estar social fosse igual ao da distribuição observada (HOFFMANN,1998). A formulação matemática deste conceito consta na equação 7.

$$
W=\sum U\left(y_{i}\right)=\sum U(\tilde{y})=n U(\tilde{y}), \operatorname{com} U(\tilde{y})=\frac{1}{n} \sum U\left(y_{i}\right)
$$

Se U(yi) for uma função côncava, então: $\tilde{y} \leq z, \operatorname{com} z=$ média de renda. No caso da igualdade de todas as rendas $\mathrm{y}_{\mathrm{i}}: \tilde{\mathrm{y}}=\mu$. Nesse caso, índice de Atkinson seria dado por:

$A=1-\frac{y}{z}$

O valor de A varia entre 0 e 1. Quanto mais igual a distribuição de renda, mais ỹ se aproximará de z, e consequentemente o índice A se aproximará de zero (SPANGER, 2003).

A interpretação da equação é a seguinte. Se ỹ for igual a $60 \%$ da média z, o índice de Atkinson será igual a 0,4. Isto significa, que o mesmo nível de bem-estar poderia ser obtido com $60 \%$ da renda total. Dada uma distribuição de renda com índice de Atkinson igual a A, o mesmo nível de bem-estar social poderia ser obtido com 100 (1-A) \% da renda total, se a distribuição fosse igualitária (HOFFMANN, 1998).

Para Vaz (2013), o coeficiente de Atkinson é composto segundo especificações semelhantes ao Gini, mas com maior sensibilidade às variações de renda nos estratos de extrema pobreza e pobreza. Varia de 0 a 1 , sendo que índices próximos a 1 indicam forte desigualdade na distribuição de renda. 


\subsection{Coeficiente de Theil-T}

Theil desenvolveu uma medida de desigualdade, derivada da teoria da entropia (COLWELL, 2011). O índice é dado pela equação a seguir:

$T=\sum_{1}^{n} s_{i} \log \left(n \times s_{i}\right) ; i=1,2,3 \ldots n$

Sendo $\mathrm{s}_{\mathrm{i}}$ é a parcela da classe i na renda total e $\mathrm{n}$ o total de classes de renda. $\mathrm{O}$ valor de T varia de zero até o infinito (SPANGER, 2003, 2008).

Para Vaz (2013), o coeficiente de Theil-T mede o quanto a distribuição de renda observada (cada indivíduo detendo uma fração específica, não necessariamente igualitária, da renda total) descola ou se afasta de uma distribuição ideal perfeitamente uniforme de distribuição dessa mesma renda (cada indivíduo detendo uma fração igualitária da renda total), ou o grau de redundância em relação a esta última, ponderandose cada observação pela parcela na renda.

Existem duas medidas de desigualdade de Theil: Theil-T e Theil-L. Enquanto, no Theil-T os fatores de ponderação da desigualdade dentro dos grupos são dados pela fração da renda apropriada, no Theil-L os fatores de ponderação da desigualdade dentro dos grupos são as populações dos grupos (PEÑA ET ALLI, 2015).

\subsubsection{Propriedades das medidas para aferir a desigualdade}

Spanger (2003) define as seguintes propriedades para as medidas de desigualdade: (i) independência da média: a multiplicação de todas rendas, pelo mesmo fator, não altera a medida; (ii) invariância da população: se o agrupamento da população muda, a medida não deve mudar; (iii) simetria: a troca entre rendas não deve afetar a medida; (iv) condição de Pigou-Dalton: a transferência de renda de ricos para pobres diminui a medida de desigualdade; (v) decomposição: a população pode ser dividida em subgrupos.

A escolha por um ou outro método é instrumental dependendo dos propósitos da análise e nada impedindo que dois (ou mais) métodos sejam utilizadas simultaneamente (MEDEIROS, 2006). 
Quadro 2 - Propriedades das medidas para aferir a desigualdade

\begin{tabular}{|c|c|c|c|c|c|}
\hline \multirow[b]{2}{*}{ Métodos } & \multicolumn{5}{|c|}{ Propriedade } \\
\hline & $\begin{array}{l}\text { Independência da } \\
\text { Média }\end{array}$ & $\begin{array}{l}\text { Invariância da } \\
\text { população }\end{array}$ & Simetria & $\begin{array}{c}\text { Condição } \\
\text { Pigou-Dalton }\end{array}$ & Decomposição \\
\hline Variância & $X$ & $\mathrm{X}$ & $\mathrm{X}$ & $\mathrm{X}$ & \\
\hline Curva de Lorenz & $\mathrm{X}$ & & $\mathrm{X}$ & $\mathrm{X}$ & \\
\hline $\begin{array}{l}\text { Curva de Lorenz } \\
\text { Generalizada }\end{array}$ & X & $X$ & $X$ & $X$ & \\
\hline $\begin{array}{c}\text { Proporção entre } \\
10 \% \text { mais ricos e } \\
\text { os } 10 \% \text { mais } \\
\text { pobres }\end{array}$ & $X$ & $\mathrm{X}$ & $X$ & & \\
\hline Gini & $\mathrm{X}$ & $\mathrm{X}$ & $X$ & $X$ & \\
\hline Theil-T & $\mathrm{X}$ & $\mathrm{X}$ & $X$ & $\mathrm{X}$ & \\
\hline Atkinson & $\mathrm{X}$ & $\mathrm{X}$ & $\mathrm{X}$ & $\mathrm{X}$ & $\mathrm{X}$ \\
\hline
\end{tabular}

Fonte: Adaptado de Hoffman (1998) e Spanger (2003).

Comparando os diversos índices de desigualdade usados nas análises de desigualdade constantes no Quadro 2, observa-se que o índice de Atkinson seria o mais completo, porém o mesmo não está disponível nas bases de dados do governo.

\subsection{Funções Econômicas do Orçamento}

A Escola Keynesiana defendia que o governo deveria interferir na economia por meio de políticas fiscais e monetárias, a fim de promover o pleno emprego, a estabilidade dos preços e o crescimento econômico (KEYNES, 1996).

Para combater a recessão ou a depressão, o governo deveria aumentar seus gastos ou reduzir os impostos (sendo que esta última opção aumentaria os gastos com consumo privado). Para conter a inflação ocasionada por gastos agregados excessivos, o governo deveria reduzir seus próprios gastos, aumentar os impostos para reduzir os gastos com consumo privado ou reduzir a oferta de moeda para elevar as taxas de juros, o que refrearia os gastos excessivos com investimentos (BRUE, 2005). 
Figura 3 - Formas Intervenção Estatal na Economia.

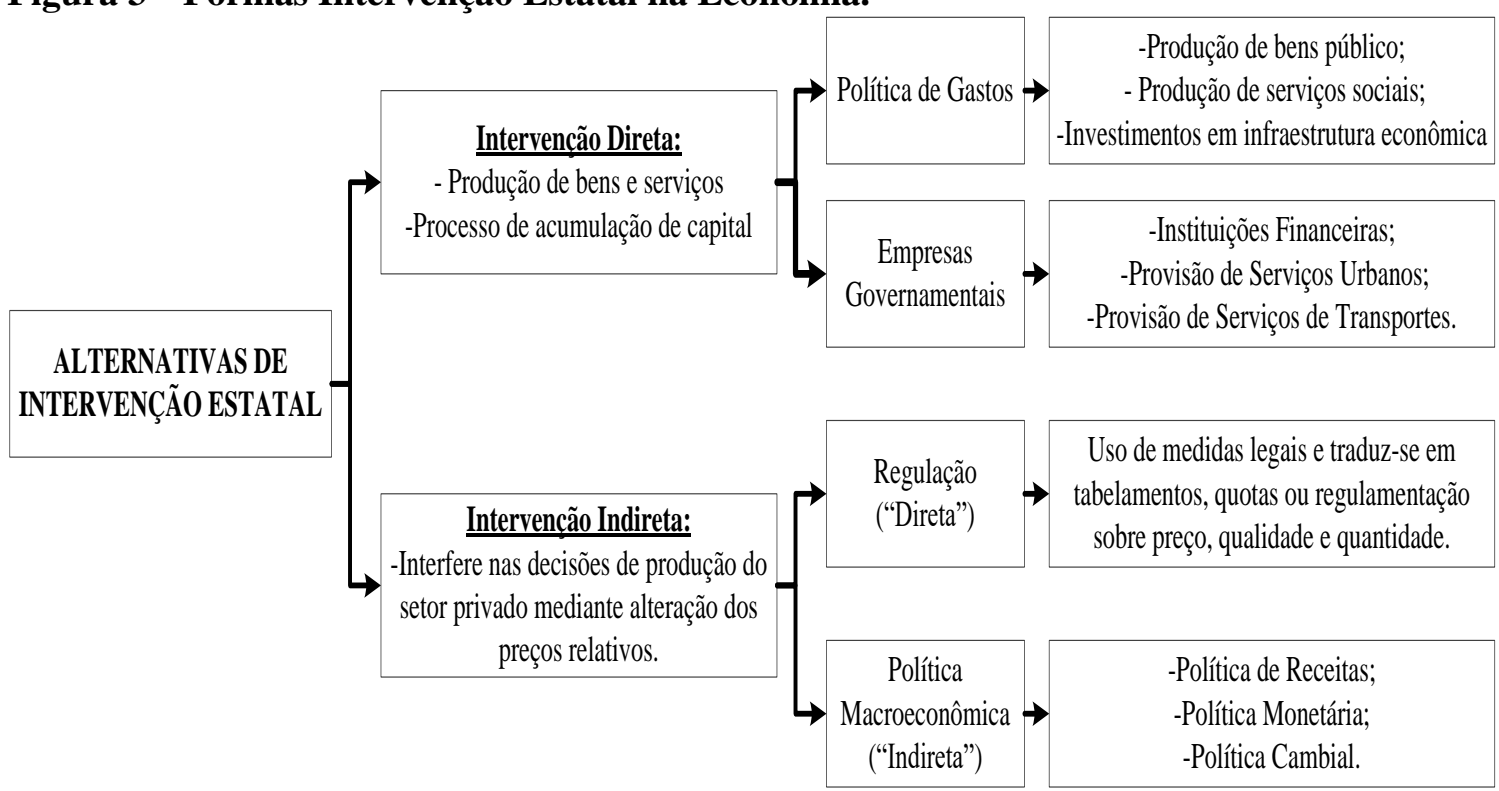

Fonte: Adaptado de Rezende (2001).

Observa-se, pela Figura 3, que o Estado pode intervir na economia de forma direta e indireta. Dentre as formas de intervenção direta destacam-se a política de despesas e as empresas estatais (REZENDE, 2001). Na política de despesas, a qual é refletida no orçamento, o Estado atua como principal cliente do mercado interno ${ }^{3}$; enquanto as estatais atuam em setores estratégicos da indústria.

Dentre as formas de intervenção indireta destacam-se a política de receitas e regulação (REZENDE, 2001). A política de receita, que está relacionada diretamente ao sistema tributário, compreende entre outras medidas o aumento de impostos ou a renúncia de receitas ${ }^{4}$; enquanto na regulação o governo, representado pelas agências reguladoras, interfere no preço, na qualidade e na quantidade das concessões públicas.

Seguindo linha similar de intervenção estatal na economia, Musgrave e Musgrave (1980) estabeleceram que é de competência do estado a execução de três funções típicas: (i) a função alocativa, (ii) a função distributiva e a (iii) função estabilizadora. O Quadro 3 contém as características das funções.

\footnotetext{
${ }^{3} \mathrm{Na}$ União Europeia $15 \%$ do PIB são compras governamentais, enquanto no Brasil as compras governamentais são perto de $10 \%$ do PIB (TORRES, 2012).

${ }^{4}$ Em 2016 o governo estimou uma renúncia em torno de R\$ 295 bilhões de reais (BRASIL, 2015) o que equivale a $10 \%$ do orçamento fiscal e da seguridade social que totaliza $\mathrm{R} \$ 2,95$ trilhões de reais.
} 
Quadro 3 - Funções Econômicas do Orçamento

\begin{tabular}{|c|c|}
\hline Função & Característica \\
\hline $\begin{array}{l}\text { Função } \\
\text { Alocativa }\end{array}$ & $\begin{array}{l}\text { Consiste na provisão de bens públicos, ou processo pelo qual o uso de } \\
\text { recursos totais da economia é dividido entre bens públicos e privados e pelo } \\
\text { qual a composição dos bens públicos é escolhida; os bens públicos não podem } \\
\text { ser oferecidos de forma compatível com as necessidades da sociedade através } \\
\text { do sistema de mercado. O fato de os benefícios gerados pelos bens públicos } \\
\text { estarem disponíveis a todos os consumidores, faz com que não haja } \\
\text { pagamento voluntário aos fornecedores desses bens. Assim, o governo se } \\
\text { encarrega de determinar o tipo e a quantidade de bens públicos a serem } \\
\text { ofertados e a calcular o nível de contribuição de cada consumidor. } \\
\text { Além dos bens públicos puros, o Estado pode prover bens semipúblicos como } \\
\text { educação e saúde. Esses bens, apesar de rivais e excludentes e poderem ser } \\
\text { fornecidos pelo mercado, possuem externalidades positivas que justificam } \\
\text { sua provisão ou subsídio pelo setor público. }\end{array}$ \\
\hline Distributiva & $\begin{array}{l}\text { Refere-se à organização da distribuição da renda, resultante dos fatores de } \\
\text { produção - capital, trabalho e terra - e da venda dos serviços desses fatores } \\
\text { no mercado. Ela pode ser feita através do mecanismo das transferências, dos } \\
\text { impostos progressivos e dos subsídios para assegurar conformidade com o } \\
\text { que a sociedade considera uma situação justa de distribuição. }\end{array}$ \\
\hline Estabilizadora & $\begin{array}{l}\text { Relaciona-se ao uso da política orçamentária com o objetivo de manter o } \\
\text { pleno emprego. Essa política pode se manifestar diretamente, através da } \\
\text { variação dos gastos públicos em consumo e investimento, ou indiretamente, } \\
\text { pela redução das alíquotas de impostos, que eleva a renda disponível do setor } \\
\text { privado. }\end{array}$ \\
\hline
\end{tabular}

Fonte: Musgrave e Musgrave (1980)

A partir do conceito das funções econômicas do orçamento, identificam-se as seguintes variáveis na função alocativa, gastos com saúde e educação; na função distributiva: impostos progressivos e transferências de renda direta; na função estabilizadora: inflação e nível de emprego. Este estudo tem como foco a função alocativa e a função distributiva.

\subsubsection{Função Orçamentária Alocativa}

Aspecto importante relacionado à função alocativa destacado por Rezende (2001), Musgrave e Musgrave (1980) e Giacomoni (2012), seriam os casos que justificariam seu respectivo uso. Os autores alegam que a função alocativa justifica-se nas situações em que não houver a necessária eficiência por parte do mecanismo de ação privada, ou seja, ocorrer uma falha de mercado 5 .

Na visão dos autores, duas situações exemplificariam tal intervenção justificada: (i) os investimentos na infraestrutura econômica como transportes, energia, comunicações, armazenamento etc.; (ii) bens semipúblicos ou meritórios.

\footnotetext{
${ }^{5}$ Uma situação em que o sistema de mercado (lei da oferta e procura), por si só, fracassa ao alocar recursos com eficiência (GIAMBIAGI; ALÉM, 2008).
} 
Os investimentos na infraestrutura econômica, tais como energia, transportes e comunicações, inerentes ao desenvolvimento regional e nacional, demandam altos investimentos e necessitam de longo período para obtenção de retorno sobre o investimento, desestimulando a iniciativa do setor privado nesses setores (MUSGRAVE; MUSGRAVE, 1980; REZENDE, 2001; GIACOMONI, 2012). Assim, considerando que o sistema de mercado não funcionaria de forma eficiente em tal situação, a intervenção do Estado seria justificada.

Já a demanda por bens públicos possui características peculiares que tornam inviável seu fornecimento de forma eficiente pelo sistema de mercado. O Quadro 4 contém as características dos bens públicos e privados (MUSGRAVE; MUSGRAVE, 1980; REZENDE, 2001; GIACOMONI, 2012).

\begin{tabular}{|c|c|c|c|}
\hline $\begin{array}{c}\text { Tipo de } \\
\text { bem }\end{array}$ & $\begin{array}{l}\text { Quanto ao uso do } \\
\text { consumidor }\end{array}$ & $\begin{array}{c}\text { Quanto à } \\
\text { Rivalidade }\end{array}$ & Quanto à exclusão \\
\hline Privado & $\begin{array}{l}\text { Está limitado a um } \\
\text { consumidor qualquer. }\end{array}$ & $\begin{array}{l}\text { Há rivalidade no } \\
\text { consumo. }\end{array}$ & $\begin{array}{c}\text { O consumidor é excluído no caso } \\
\text { de não pagamento. }\end{array}$ \\
\hline Público & $\begin{array}{l}\text { Não está limitado a um } \\
\text { consumidor qualquer. }\end{array}$ & $\begin{array}{c}\text { Não há rivalidade no } \\
\text { consumo. }\end{array}$ & $\begin{array}{l}\text { O consumidor não é excluído no } \\
\text { caso de não pagamento. }\end{array}$ \\
\hline
\end{tabular}

Fonte: Rezende (2001), Musgrave e Musgrave (1980), Giacomoni (2012).

Conforme consta no Quadro 4, o bem privado é oferecido por meio dos mecanismos próprios do sistema de mercado. Há uma troca entre vendedor e comprador e uma transferência da propriedade do bem. O não pagamento por parte do comprador impede a operação e, logicamente, o benefício. A operação toda é, portanto, eficiente (MUSGRAVE; MUSGRAVE, 1980; REZENDE, 2001; GIACOMONI, 2012).

No caso do bem público, o sistema de mercado não teria a mesma eficiência. Os benefícios geralmente não podem ser individualizados nem recusados pelos consumidores. Não há como excluir o consumidor pelo não pagamento. Aqui, o processo político substitui o sistema de mercado. Ao eleger seus representantes (legisladores e administradores) o eleitor-consumidor aprova determinada plataforma (programa de governo) para cujo financiamento irá contribuir mediante tributos. (MUSGRAVE; MUSGRAVE, 1980; REZENDE, 2001; GIACOMONI, 2012). 
Além das duas classificações de bens, pode haver casos em que um bem é somente não rival ou somente não exclusivo. Nestes casos, esses bens serão chamados de bens semipúblicos (“quase públicos”), que são bens que possuem apenas parte das características dos bens públicos. Esses bens apresentariam características de bens privados (divisibilidade, ou exclusão, ou rivalidade) podendo ser fornecidos via sistema de mercado, porém por possuírem externalidades positivas, são disponibilizados pelo setor público. Os principais exemplos de bens dessa natureza são os bens e serviços nas áreas de educação e saúde (MUSGRAVE; MUSGRAVE, 1980; REZENDE, 2001; GIACOMONI, 2012).

\subsubsection{Função Orçamentária Distributiva}

As doutrinas de bem-estar integradas na análise econômica convencional derivam da formulação consagrada pelo nome de "ideal de Pareto", segundo o qual: há eficiência na economia quando a posição de alguém sofre uma melhoria sem que nenhum outro tenha sua situação deteriorada (CORDATO, 1980; MUSGRAVE; MUSGRAVE, 1980; REZENDE, 2001; GIACOMONI, 2012).

Assim, a função pública de promover ajustamentos na distribuição de renda justifica-se uma como correção às falhas de mercado (desigualdades sociais, monopólios empresariais, etc.) inerentes ao sistema econômico capitalista. Para tanto, deve-se fugir da idealização de Pareto, pois a melhoria da posição de certas pessoas é feita às expensas de outras (MUSGRAVE; MUSGRAVE, 1980; REZENDE, 2001; GIACOMONI, 2012).

Por uma série de razões, a apropriação da renda e da riqueza se dá de forma diferenciada na sociedade e, na maioria dos casos, ela se apresenta de forma bastante concentrada. As forças do mercado, ao invés de amenizar este fato tendem a perpetuá-lo, quando não o acentuar. A função de distribuição do governo tem como principal objetivo utilizar mecanismos que visem ajustar a distribuição da renda e da riqueza na sociedade, tornando-a menos desigual possível, fazendo-a socialmente aceitável e economicamente funcional. Assim, podem-se utilizar mecanismos como: transferências, impostos progressivos ou subsídios (MUSGRAVE; MUSGRAVE, 1980; REZENDE, 2001; GIACOMONI, 2012). 


\subsubsection{Função Orçamentária Estabilizadora}

Antes se acreditava que o mercado tinha capacidade de auto ajustar-se ao pleno emprego da economia. A flexibilidade de preços e de salários garantiria esse equilíbrio. Depois se constatou que o mercado não é capaz de assegurar altos níveis de emprego, estabilidade nos preços e altas taxas de crescimento econômico (MUSGRAVE; MUSGRAVE, 1980; REZENDE, 2001; GIACOMONI, 2012).

Assim, a função estabilizadora, a mais moderna das três funções, utiliza instrumentos macroeconômicos para manter certo nível de utilização de recursos, estabilizar o valor da moeda, assegurar o nível de emprego e a estabilidade dos preços que não são resultados automáticos do funcionamento do sistema de mercado, mas exigem intervenção do poder público (MUSGRAVE; MUSGRAVE, 1980; REZENDE, 2001; GIACOMONI, 2012).

O orçamento público na década de 30 constitui-se em importante instrumento de combate à depressão e a partir daí esteve sempre em cena, lutando contra altas inflacionárias e contra o desemprego. Em qualquer economia, os níveis de preços e de emprego resultam dos níveis da demanda agregada, isto é, da disposição de gastar dos consumidores, das famílias, dos capitalistas, enfim, de qualquer tipo de comprador. Se a demanda for superior à capacidade nominal (potencial) da produção, os preços tenderão a subir; se for inferior, haverá desemprego. O mecanismo básico da política de estabilização é, portanto, a ação estatal sobre a demanda agregada, aumentando-a ou reduzindo-a conforme as necessidades (MUSGRAVE; MUSGRAVE, 1980; REZENDE, 2001; GIACOMONI, 2012). 


\subsection{Federalismo fiscal e os instrumentos fiscais}

Christensen e Wise (2009) definem o federalismo governamental como um sistema de leis que dividem as responsabilidades públicas entres as diversas unidades de governo.

Para Rezende (2001), o federalismo fiscal se constitui em uma técnica administrativa que possibilita o exercício do poder em territórios de grande amplitude. É um método de organização administrativa nacional que se baseia no estabelecimento de governos de âmbitos central, regional e local. Este arranjo financeiro estabelece regras para divisão das receitas, das despesas e dos encargos na federação a partir do compromisso dos residentes das unidades federadas (REZENDE, 2001).

De acordo com o teorema da descentralização de Oates (1977, 2006, 2008) julgase preferível a atribuição de encargos em níveis inferiores de governo que têm condições de melhor adaptação às preferências dos usuários. No entanto, conforme será exposto na seção 2.3.1, mesmo em uma Federação determinadas funções do Estado ficam a cargo do poder central, seja devido aos ganhos de escalas, seja devido às externalidades positivas geradas.

A seguir serão apresentados três aspectos do federalismo fiscal que impactam os instrumentos fiscais: (i) a responsabilidade pelas funções econômicas do orçamento; (ii) sistema tributário, (iii) sistema de transferências de recursos.

\subsubsection{Impactos sobre as funções econômicas orçamentárias em uma Federação}

A seção 2.2 contém os conceitos gerais das três funções econômicas do orçamento aplicáveis a qualquer tipo de Estado. Porém, quando se tem por objeto de estudo uma federação, fatores adicionais devem ser considerados.

\subsubsection{Função orçamentária alocativa}

O teorema da descentralização de Oates (1977, 2006, 2008) afirma que há maximização da eficiência econômica da ordenação federativa fiscal alocativa sempre que for observada perfeita correspondência entre as ações do governo e a preferência dos grupos que o financiam. 
Aplicado o teorema de Oates ao caso brasileiro, Silva (2005) afirma que o governo central deve responder pela provisão de bens cujo consumo seja uniforme, em termos de preferência e em termos de quantidade individual demandada em todo o território federativo; enquanto os governos estaduais assumiriam a responsabilidade pela provisão de itens com preferências regionais, e os governos locais responderiam pelos bens cujo perfil da demanda fosse especifico de uma localidade (SILVA, 2005).

A autonomia fiscal das jurisdições e a livre mobilidade dos consumidores são as premissas que melhor captam a essência do mecanismo proposto por Tiebout (1956). No modelo do autor a partir do mecanismo "votando com os pés" cada consumidor escolheria a comunidade que oferece para si próprio a combinação ótima de serviço público e impostos garantindo assim a eficiência.

\subsubsection{Função orçamentária distributiva}

A política distributiva pode ser implementada pela operacionalização de três instrumentos, a saber: (i) a progressividade do sistema tributário; (ii) o direcionamento das transferências fiscais intergovernamentais; (iii) o perfil da cesta de bens provisionados pelo governo (SILVA, 2005).

Essas ações são identificadas como tarefas primordialmente destinadas ao governo central do estado federativo, por demandarem procedimentos em escala nacional e uniformidade capaz de eliminar possibilidades de deslocamento espacial dos fatores produtivos. Ações dessa natureza, quando adotadas por governos subnacionais, num quadro de ampla mobilidade de fatores, podem ser neutralizadas por dois movimentos: (i) o deslocamento de famílias de baixa renda para a jurisdição gestora das transferências; (ii) a busca por outras jurisdições por parte dos indivíduos e das unidades produtivas, detentoras de alto padrão de renda, à procura de menor custo tributário (MUSGRAVE; MUSGRAVE, 1980; SILVA, 2005).

\subsubsection{Função orçamentária estabilizadora}

As políticas fiscais orientadas à estabilização sejam elas restritivas, sejam expansionistas, quando adotadas isoladamente pelos governos subnacionais, acabam parcialmente anuladas pelos efeitos de transbordamento, decorrentes da ampla mobilidade de fatores entre jurisdições de um mesmo Estado federativo. 
Musgrave e Musgrave (1980) afirmam que as ações de política fiscal de natureza expansionista tendem a perder eficiência e eficácia por meio dos transbordamentos comerciais; e que os aumentos dos gastos locais seriam parcialmente transferidos para outras jurisdições via compra de mercadorias e serviços. As ações restritivas tenderiam a reduzir a demanda e a pressionar os preços para baixo, gerando incentivos sobre demandas oriundas de outras comunidades fiscais do mesmo universo federativo. Nos dois casos, os esforços desenvolvidos unilateralmente por uma unidade federativa seriam parcialmente neutralizados, gerando ineficiências econômicas. Esse é o argumento central utilizado por Oates $(1977,2006,2008)$ para fundamentar teoricamente a delegação, ao governo central, das competências associadas à estabilização.

\subsubsection{Reponsabilidade pelas funções econômicas do orçamento no federalismo fiscal}

O Quadro 5 resume a relação entre o governo central e os governos subnacionais quanto às funções econômicas do orçamento.

Quadro 5 - Funções econômicas do orçamento no federalismo fiscal

\begin{tabular}{|c|l|l|l|}
\hline Governos & \multicolumn{1}{|c|}{ Alocativa } & \multicolumn{1}{|c|}{ Distributiva } & \multicolumn{1}{|c|}{ Estabilizadora } \\
\hline Central & $\begin{array}{l}\text { Bens cujo consumo seja } \\
\text { uniforme, em termos de } \\
\text { preferência e em termos de } \\
\text { quantidade individual } \\
\text { demandada em todo o } \\
\text { território federativo. }\end{array}$ & Destinadas ao governo central do Estado federativo. \\
\hline Regional & $\begin{array}{l}\text { Provisão de itens com } \\
\text { preferências regionais. }\end{array}$ & $\begin{array}{l}\text { Quando adotadas por } \\
\text { governos subnacionais, } \\
\text { num quadro de ampla } \\
\text { mobilidade de fatores, } \\
\text { podem ser neutralizadas. }\end{array}$ & $\begin{array}{l}\text { Os esforços desenvolvidos } \\
\text { unilateralmente por uma } \\
\text { unidade federativa seriam } \\
\text { parcialmente neutralizados, } \\
\text { gerando ineficiências } \\
\text { econômicas. }\end{array}$ \\
\hline & $\begin{array}{l}\text { Bens cujo perfil da demanda } \\
\text { fosse especifico de uma } \\
\text { localidade. }\end{array}$
\end{tabular}

Fonte: Adaptado de Oates (1977, 2006, 2008), Musgrave e Musgrave (2005), Silva (2005).

Conclui-se que as funções orçamentárias distributiva e estabilizadora devem ser conduzidas pelo governo central, enquanto que a função alocativa pode ser conduzida pelas três esferas.

\subsubsection{Impactos sobre o Sistema Tributário}

Ao analisar a tributação em ambiente federativo, Ter-Minassian (1997) sugere que a distribuição de competências tributárias entre diferentes níveis de governo deve obedecer aos seguintes critérios definidos no Quadro 6. 
Quadro 6 - Critérios para segregação de tributos no âmbito de uma Federação

\begin{tabular}{|c|c|c|}
\hline Categoria & Critério & Observação \\
\hline \multirow{4}{*}{$\begin{array}{l}\text { Tributos de } \\
\text { competência do } \\
\text { governo central }\end{array}$} & $\begin{array}{l}\text { Alta mobilidade da base de } \\
\text { arrecadação }\end{array}$ & $\begin{array}{l}\text { A adoção desses por governos } \\
\text { subnacionais poderia implicar a indução } \\
\text { aos deslocamentos inter-regionais dos } \\
\text { fatores de produção, com custos de } \\
\text { eficiência para o conjunto da Federação. }\end{array}$ \\
\hline & $\begin{array}{l}\text { Forte sensibilidade } r \\
\text { mudanças no nível de } \\
\text { crescimento da economia } \\
\text { (grau acentuado de } \\
\text { elasticidade-renda) }\end{array}$ & $\begin{array}{l}\text { Representa um relevante instrumento de } \\
\text { ação da política de estabilização. }\end{array}$ \\
\hline & $\begin{array}{l}\text { Bases de arrecadação } \\
\text { relevantes e distribuídas } \\
\text { irregularmente entre as } \\
\text { diversas regiões e unidades } \\
\text { federadas }\end{array}$ & $\begin{array}{l}\text { Dado que a descentralização de tributos } \\
\text { com esse perfil acentua o grau de } \\
\text { assimetria inter-regional }\end{array}$ \\
\hline & $\begin{array}{l}\text { Tributos incidentes sobre o } \\
\text { comércio exterior } \\
\text { importação e exportações }\end{array}$ & $\begin{array}{l}\text { São instrumentos reguladores das trocas } \\
\text { externas e influenciam a balança } \\
\text { comercial. }\end{array}$ \\
\hline \multirow{2}{*}{$\begin{array}{l}\text { Tributos de } \\
\text { competência dos } \\
\text { governos } \\
\text { subnacionais }\end{array}$} & $\begin{array}{l}\text { Baixa mobilidade da base de } \\
\text { incidência. }\end{array}$ & \multirow[b]{2}{*}{ Sem observações adicionais. } \\
\hline & $\begin{array}{l}\text { Tributos do tipo taxas por } \\
\text { serviços públicos prestados à } \\
\text { comunidade. }\end{array}$ & \\
\hline
\end{tabular}

Fonte: Adaptado de Ter-Minassian (1997)

Ainda quanto ao Quadro 6, cabe destacar que basta o atendimento de um dos critérios para que o tributo seja incluído na respectiva categoria.

\subsubsection{Impactos sobre o Sistema de Transferências de Recursos}

Bahl e Wallace (2005) definem três possíveis classificações de transferência: (i) vertical e horizontal; (ii) conditional grants e unconditional grants; (iii) matching (com contrapartida) e non matching grants (sem contrapartida).

As transferências verticais ocorrem do nível nacional para o nível regional e local ou do nível regional para o nível local; enquanto as transferências horizontais ocorrem entre entes do mesmo nível (regional para regionais; local para local) (BAHL; WALLACE, 2005).

As transferências condicionais devem ser aplicadas em determinada área específica de gasto ou exigem contrapartida, enquanto as incondicionais podem ser aplicadas em qualquer área do gasto e dispensam contrapartida (BAHL; WALLACE, 2005). 
As transferências com contrapartida são aquelas que necessitam aporte de recursos do ente recebedor, enquanto as transferências sem contrapartida não exigem qualquer aporte de recursos do ente recebedor (BAHL; WALLACE, 2005).

Para Oates $(1977,2006,2008)$ três motivos justificam a existência de repasses financeiros horizontais e verticais entre unidades federadas, para que essas possam fazer frente aos encargos de suas respectivas competências, quais sejam: (i) externalidades; (ii) compensações; (iii) redistribuição de renda.

O motivo "externalidades" está associado à correção dos custos ou benefícios gerados pelos efeitos externos que o sistema econômico de uma jurisdição exerce sobre outras. São pagas indenizações ou subsídios, conforme seja a natureza da externalidade, respectivamente, negativa ou positiva. A imposição de pagamento indenizatório ou o recebimento em forma de subsídios funciona como sinalização orientada, respectivamente, à inibição ou ao incentivo do desenho produtivo gerador da externalidade (OATES, 1977, 2006, 2008).

O motivo "compensação" está relacionado à necessidade de mecanismos tributários, cuja arrecadação, por razões de eficiência econômica, precisa ser realizada por jurisdições com abrangência estadual ou pelo governo central. Essa configuração obriga a esfera arrecadadora a realizar transferências com o objetivo de compensar regiões tributadas e viabilizar os gastos dos respectivos governos. A devolução total ou parcial dos recursos permite aos agentes econômicos geradores do esforço tributário maior autonomia para a realização das escolhas e maior possibilidade de correspondência entre preferências e provisões públicas (OATES, 1977, 2006, 2008).

Por fim, o motivo "redistribuição" está vinculado aos objetivos orientados à (i) redução das diferenças fiscais entre unidades federativas, derivadas dos diferenciais relacionados ao grau de desenvolvimento da atividade econômica, (ii) à dimensão da base tributária, (iii) aos custos de produção e (iv) ao perfil da demanda por bens cuja provisão é de responsabilidade do setor governo (OATES, 1977, 2006, 2008).

No entendimento de Ter-Minassian (1997) um sistema de transferências é composto por dois elementos: cotas (revenue sharing) e concessões (grants). O Quadro 7 contém as especificidades de cada uma. 
Quadro 7 - Formas de repartição de recursos em um sistema de transferências

\begin{tabular}{|c|c|}
\hline Forma & Caraterísticas \\
\hline \multirow{4}{*}{$\begin{array}{c}\text { Transferências } \\
\text { por cotas } \\
\text { (revenue } \\
\text { sharing) }\end{array}$} & $\begin{array}{l}\text { São previamente determinadas por dispositivos constitucionais ou leis } \\
\text { ordinárias }\end{array}$ \\
\hline & $\begin{array}{l}\text { Podem estar associadas a umimposto específico ou a montantes disponíveis } \\
\text { em fundos públicos constituídos por recursos com origem tributária } \\
\text { diversificada }\end{array}$ \\
\hline & $\begin{array}{l}\text { Podem ter a finalidade compensatória, sugerida nos casos em que o repasse } \\
\text { é realizado com o objetivo de devolver recursos de uma base tributária } \\
\text { específica, cuja arrecadação se processou no território da jurisdição } \\
\text { beneficiada, ainda que essa não tenha assumido a responsabilidade pela } \\
\text { operacionalização da arrecadação }\end{array}$ \\
\hline & $\begin{array}{l}\text { Podem ter a finalidade redistributiva, sugerida nos casos em que os recursos } \\
\text { são repassados segundo critérios que guardam uma relação inversamente } \\
\text { proporcional à renda e diretamente proporcional à população e aos } \\
\text { indicadores de carências associados à disponibilidade de bens públicos ou } \\
\text { meritórios. }\end{array}$ \\
\hline \multirow{4}{*}{$\begin{array}{l}\text { Transferências } \\
\text { por concessões } \\
\quad(\text { grants })\end{array}$} & $\begin{array}{l}\text { Estão vinculadas à execução de políticas públicas setoriais e independem de } \\
\text { previsão legal específica. }\end{array}$ \\
\hline & $\begin{array}{l}\text { As unidades transferidoras dispõem de autonomia para decidir sobre o } \\
\text { montante e os requisitos necessários ao credenciamento para recebimento } \\
\text { dos recursos. }\end{array}$ \\
\hline & $\begin{array}{l}\text { Dependem de acordos negociados entre unidades federativas de governo e } \\
\text { podem depender de condições impostas pela esfera repassadora, } \\
\text { relacionadas ao desempenho da unidade solicitante na gestão de programas } \\
\text { específicos ou de critérios de arrecadação, endividamento e transparência } \\
\text { da gestão fiscal }\end{array}$ \\
\hline & $\begin{array}{l}\text { Possuem natureza fiscal federativa uma vez que não guardam relação direta } \\
\text { com os motivos: externalidade, compensação e redistribuição federativa. }\end{array}$ \\
\hline
\end{tabular}

Fonte: Adaptado de Ter-Minassian (1997)

Ainda, quanto aos critérios para distribuição de transferências, Bahl e Wallace (2005) sugerem os seguintes: (i) proporcionalidade à arrecadação do próprio imposto da unidade; (ii) proporcionalidade à população e à área da unidade; (iii) proporcionalidade inversa à renda gerada em cada unidade. Estes dois últimos critérios também são aceitos por Ter-Minassian (1997). 
2.4 Estado da Arte sobre os Efeitos das Funções Alocativa e Distributiva sobre as Desigualdades de Renda

Diversos estudos buscaram avaliar os efeitos das variáveis fiscais sobre a desigualdade de renda. Porém, conforme exposto na seção 2.1 pode-se aferir a desigualdade sob diferentes perspectivas o que acarreta uma pluralidade de variáveis dependentes, variáveis independentes e métodos. O Quadro 8 mostra os estudos sobre o tema com os respectivos fatores relevantes. 
Quadro 8 - Estudos anteriores sobre desigualdades e instrumentos fiscais

\begin{tabular}{|c|c|c|c|c|c|c|c|}
\hline \multirow[b]{2}{*}{ Fonte } & \multirow[b]{2}{*}{ Amostra } & \multirow[b]{2}{*}{ Período } & \multirow{2}{*}{$\begin{array}{c}\text { Estrutura dos } \\
\text { Dados }\end{array}$} & \multicolumn{2}{|c|}{ Medidas } & \multicolumn{2}{|c|}{ Correlação } \\
\hline & & & & $\begin{array}{c}\text { Função alocativa e } \\
\text { distributiva }\end{array}$ & Função Desigualdade & Sinal & Significância \\
\hline $\begin{array}{l}\text { Perroti } \\
(1994)\end{array}$ & 52 países & $\begin{array}{c}1970- \\
1985\end{array}$ & $\begin{array}{c}\text { Série temporal } \\
\text { da média dos } \\
\text { países }\end{array}$ & Transferências & Q3 em 1960 & Negativo & Não significativo \\
\hline $\begin{array}{c}\text { Persson e } \\
\text { Tabellini } \\
(1994) \\
\end{array}$ & $\begin{array}{l}13 \text { países } \\
\text { da OCDE }\end{array}$ & $\begin{array}{l}1960- \\
1981\end{array}$ & $\begin{array}{c}\text { Série temporal } \\
\text { da média dos } \\
\text { países } \\
\end{array}$ & Transferências & Q3 em 1965 & Positivo & Não significativo \\
\hline $\begin{array}{l}\text { Perotti } \\
(1996)\end{array}$ & 49 países & $\begin{array}{l}1970- \\
1985\end{array}$ & $\begin{array}{c}\text { Série temporal } \\
\text { da média dos } \\
\text { países }\end{array}$ & $\begin{array}{c}\text { Alíquotas e } \\
\text { impostos e gastos } \\
\text { públicos } \\
\end{array}$ & Q3 e Q4 em 1960 & Geralmente positivo & $\begin{array}{c}\text { Geralmente não } \\
\text { significativo }\end{array}$ \\
\hline $\begin{array}{c}\text { Lindert } \\
(1996)\end{array}$ & $\begin{array}{l}14 \text { países } \\
\text { da OCDE }\end{array}$ & $\begin{array}{l}1962- \\
1981\end{array}$ & $\begin{array}{l}\text { Painel MQO } \\
\text { (MQO) }\end{array}$ & Gastos públicos & $\begin{array}{l}\text { Variação do índice de } \\
\text { receita }\end{array}$ & Negativa & $\begin{array}{c}\text { Geralmente não } \\
\text { significativo }\end{array}$ \\
\hline $\begin{array}{l}\text { Partridge } \\
\text { (1997) }\end{array}$ & $\begin{array}{c}8 \text { estados } \\
\text { dos EUA }\end{array}$ & $\begin{array}{l}1960- \\
1990\end{array}$ & Painel MQO & $\begin{array}{c}\text { Impostos, emprego } \\
\text { e gastos }\end{array}$ & $\begin{array}{c}\text { Coeficiente de Gini } \\
\text { antes dos impostos, Q3 }\end{array}$ & Inconclusivo & $\begin{array}{l}\text { Geralmente } \\
\text { significativo }\end{array}$ \\
\hline $\begin{array}{c}\text { Gouveia e } \\
\text { Masia (1998) }\end{array}$ & $\begin{array}{c}50 \text { estados } \\
\text { dos EUA }\end{array}$ & $\begin{array}{l}1979- \\
1991\end{array}$ & Painel MQO & Gastos públicos & $\begin{array}{l}\text { Taxa da média para } \\
\text { mediana da receita }\end{array}$ & Geralmente negativa & $\begin{array}{l}\text { Geralmente } \\
\text { significativo }\end{array}$ \\
\hline Figini (1998) & 63 países & $\begin{array}{l}1970- \\
1990\end{array}$ & $\begin{array}{c}\text { Série temporal } \\
\text { da média dos } \\
\text { países }\end{array}$ & $\begin{array}{c}\text { Alíquotas dos } \\
\text { impostos, receita } \\
\text { total e gasto total } \\
\end{array}$ & Coeficiente de Gini & Inconclusivo & Significativo \\
\hline $\begin{array}{c}\text { Bassett, } \\
\text { Burkett e } \\
\text { Putterman } \\
(1999)\end{array}$ & 54 países & $\begin{array}{l}1970- \\
1985\end{array}$ & $\begin{array}{c}\text { Série temporal } \\
\text { da média dos } \\
\text { países }\end{array}$ & $\begin{array}{l}\text { Seguridade Social e } \\
\text { bem-estar social }\end{array}$ & Q3 em 1960 & Geralmente negativo & Inconsistente \\
\hline $\begin{array}{c}\text { Panizza } \\
(1999)\end{array}$ & $\begin{array}{c}46 \text { estados } \\
\text { dos EUA }\end{array}$ & $\begin{array}{l}1970- \\
1980\end{array}$ & $\begin{array}{l}\text { Série temporal } \\
\text { da média dos } \\
\text { estados }\end{array}$ & $\begin{array}{c}\text { Impostos, impostos } \\
\text { progressivos e } \\
\text { gastos públicos }\end{array}$ & Q3 em 1970 & Geralmente positivo & Inconsistente \\
\hline
\end{tabular}




\begin{tabular}{|c|c|c|c|c|c|c|c|}
\hline \multirow[b]{2}{*}{ Fonte } & \multirow[b]{2}{*}{ Amostra } & \multirow[b]{2}{*}{ Período } & \multirow[b]{2}{*}{$\begin{array}{c}\text { Estrutura dos } \\
\text { Dados }\end{array}$} & \multicolumn{2}{|c|}{ Medidas } & \multicolumn{2}{|c|}{ Correlação } \\
\hline & & & & $\begin{array}{c}\text { Função alocativa e } \\
\text { distributiva }\end{array}$ & Função Desigualdade & Sinal & Significância \\
\hline $\begin{array}{l}\text { Rodriguez } \\
\text { (1999) }\end{array}$ & $\begin{array}{c}50 \text { estados } \\
\text { dos EUA }\end{array}$ & $\begin{array}{l}1984- \\
1994\end{array}$ & $\begin{array}{l}\text { Série temporal } \\
\text { da média dos } \\
\text { países }\end{array}$ & Gastos públicos & Distribuição assimétrica & Inconsistente & Não significativo \\
\hline $\begin{array}{l}\text { Tanninen } \\
\text { (1999) }\end{array}$ & 45 países & $\begin{array}{l}1970- \\
1988\end{array}$ & $\begin{array}{l}\text { Série temporal } \\
\text { da média dos } \\
\text { países }\end{array}$ & Gastos públicos & $\begin{array}{l}\text { Coeficiente de Gini } \\
\text { ajustado }\end{array}$ & Inconsistente & $\begin{array}{l}\text { Geralmente não } \\
\text { significativo }\end{array}$ \\
\hline $\begin{array}{l}\text { Milanovic } \\
\text { (2000) }\end{array}$ & $\begin{array}{l}24 \text { países } \\
\text { da OCDE }\end{array}$ & $\begin{array}{l}1967- \\
1997\end{array}$ & Painel MQO & $\begin{array}{c}\text { Ganho dos } 20 \% \text { ou } \\
50 \% \text { mais pobres }\end{array}$ & $\begin{array}{l}\text { Coeficiente de Gini } \\
\text { ajustado antes dos } \\
\text { impostos }\end{array}$ & Positivo & Significativo \\
\hline $\begin{array}{l}\text { Castronova } \\
\text { (2001) }\end{array}$ & $\begin{array}{l}13 \text { países } \\
\text { da OCDE }\end{array}$ & $\begin{array}{l}1962- \\
1991\end{array}$ & $\begin{array}{l}\text { MQO e MQO } \\
\text { em } 2 \text { estágios }\end{array}$ & Gastos Sociais & Renda per capta & Inconclusivo & Significativo \\
\hline $\begin{array}{c}\text { Jha, Biswal e } \\
\text { Biswal } \\
(2001)\end{array}$ & $\begin{array}{l}14 \text { estados } \\
\text { da Índia }\end{array}$ & $\begin{array}{l}1957- \\
1997\end{array}$ & Painel MQO & $\begin{array}{c}\text { Gastos com } \\
\text { educação e saúde }\end{array}$ & $\begin{array}{c}\text { Índice de pobreza: } \\
\text { longevidade, } \\
\text { alfabetização, acesso as } \\
\text { provisões (serviços de } \\
\text { saúde, água tratada, } \\
\text { crianças até } 5 \text { anos com } \\
\text { peso adequado) }\end{array}$ & $\begin{array}{l}\text { Positivo (gastos com } \\
\text { ensino superior e } \\
\text { tecnológico são mais } \\
\text { efetivos que os gastos } \\
\text { do ensino básico) }\end{array}$ & Significativo \\
\hline $\begin{array}{l}\text { Sylwester } \\
(2002)\end{array}$ & 50 países & $\begin{array}{l}1970- \\
1990\end{array}$ & Painel MQO & $\begin{array}{l}\text { Gastos com } \\
\text { educação }\end{array}$ & Coeficiente de Gini & Negativo & Significativo \\
\hline $\begin{array}{l}\text { De Mello e } \\
\text { Tiongson } \\
(2006)\end{array}$ & $\begin{array}{c}\text { Entre } 49 \text { e } \\
55 \text { países }\end{array}$ & $\begin{array}{c}1972- \\
1998, \text { e } \\
1970- \\
1998 .\end{array}$ & $\begin{array}{l}\text { Painel MQO e } \\
\text { Painel tobit }\end{array}$ & $\begin{array}{c}\text { Gastos com } \\
\text { seguridade social e } \\
\text { bem-estar } \\
\text { (percentual sobre o } \\
\text { PIB); Transferências } \\
\text { (percentual sobre o } \\
\text { PIB). }\end{array}$ & $\begin{array}{l}\text { Coeficiente de Gini, } \\
\text { renda per capita, } \\
\text { percentual da população } \\
\text { com mais de } 65 \text { anos, } \\
\text { índice de democracia. }\end{array}$ & Negativo & $\begin{array}{l}\text { Geralmente } \\
\text { significativo }\end{array}$ \\
\hline
\end{tabular}




\begin{tabular}{|c|c|c|c|c|c|c|c|}
\hline \multirow[b]{2}{*}{ Fonte } & \multirow[b]{2}{*}{ Amostra } & \multirow[b]{2}{*}{ Período } & \multirow[b]{2}{*}{$\begin{array}{l}\text { Estrutura dos } \\
\text { Dados }\end{array}$} & \multicolumn{2}{|c|}{ Medidas } & \multicolumn{2}{|c|}{ Correlação } \\
\hline & & & & $\begin{array}{c}\text { Função alocativa e } \\
\text { distributiva }\end{array}$ & Função Desigualdade & Sinal & Significância \\
\hline $\begin{array}{l}\text { Rocha } \\
\text { (2008a) }\end{array}$ & $\begin{array}{l}\text { Estados } \\
\text { do Brasil }\end{array}$ & $\begin{array}{l}2001- \\
2004\end{array}$ & $\begin{array}{l}\text { Simulações } \\
\text { utilizando o } \\
\text { hiato } \\
\text { quadrático }\end{array}$ & $\begin{array}{c}\text { Transferências de } \\
\text { Renda }\end{array}$ & $\begin{array}{l}\text { Coeficiente de Gini e } \\
\text { Coeficiente de Theil-T }\end{array}$ & $\begin{array}{l}\text { Embora as transferências } \\
\text { para a redução da } \\
\text { rendimentos entre } 2001 \\
\text { observado se deveu pre } \\
\text { melhorias na distribuiçã } \\
\text { trabalho. }\end{array}$ & $\begin{array}{l}\text { nham contribuído } \\
\text { lesigualdade de } \\
\text { 2004, o declínio } \\
\text { nderantemente a } \\
\text { o rendimento do }\end{array}$ \\
\hline $\begin{array}{l}\text { Bergh e Fink } \\
\text { (2008) }\end{array}$ & 35 países & $\begin{array}{l}1980- \\
2000\end{array}$ & Painel MQO & $\begin{array}{l}\text { Gastos com } \\
\text { educação }\end{array}$ & Coeficiente de Gini & Positivo & Significativo \\
\hline $\begin{array}{l}\text { Zhang } \\
\text { (2008) }\end{array}$ & 50 países & $\begin{array}{l}1970- \\
1990\end{array}$ & Painel MQO & $\begin{array}{c}\text { Gastos com } \\
\text { educação } \\
\text { segregados em } \\
\text { ensino médio e } \\
\quad \text { superior } \\
\end{array}$ & Coeficiente de Gini & $\begin{array}{l}\text { Negativo para ensino } \\
\text { médio e positivo para } \\
\text { ensino superior }\end{array}$ & Significativo \\
\hline $\begin{array}{l}\text { Hoffmann } \\
\text { (2010) }\end{array}$ & $\begin{array}{c}\text { Estados do } \\
\text { Brasil }\end{array}$ & $\begin{array}{l}2002- \\
2003 \text { e } \\
2008- \\
2009\end{array}$ & $\begin{array}{c}\text { Grau de } \\
\text { progressividade } \\
\text { ou } \\
\text { regressividade }\end{array}$ & $\begin{array}{l}\text { Transferências de } \\
\text { Renda }\end{array}$ & $\begin{array}{l}\text { Coeficiente de Gini e } \\
\text { Coeficiente de Theil-T }\end{array}$ & $\begin{array}{l}\text { O bolsa-família foi mais } \\
\text { progressivo que o } \\
\text { benefício de prestação } \\
\text { continuada. }\end{array}$ & Significativo \\
\hline $\begin{array}{c}\text { Holzner } \\
(2011)\end{array}$ & $\begin{array}{l}28 \text { países } \\
\text { do centro, } \\
\text { leste e } \\
\text { sudeste } \\
\text { europeu. }\end{array}$ & $\begin{array}{l}1989- \\
2006\end{array}$ & $\begin{array}{c}\text { Mínimos } \\
\text { Quadrados } \\
\text { Generalizados }\end{array}$ & Gastos & Coeficiente de Gini & $\begin{array}{l}\text { Gastos com proteção } \\
\text { social e saúde foram } \\
\text { negativamente } \\
\text { relacionados. }\end{array}$ & Significativo \\
\hline $\begin{array}{l}\text { Cavalcanti, } \\
\text { Costa e } \\
\text { Silva } \\
(2013)\end{array}$ & $\begin{array}{c}\text { Estados } \\
\text { do } \\
\text { Nordeste } \\
\text { do Brasil }\end{array}$ & $\begin{array}{l}2004- \\
2006\end{array}$ & $\begin{array}{l}\text { Propensity } \\
\text { Score } \\
\text { Matching } \\
\text { (PSM) via } \\
\text { Probit }\end{array}$ & $\begin{array}{c}\text { Transferências de } \\
\text { Renda }\end{array}$ & $\begin{array}{l}\text { Índice Foster-Greer- } \\
\text { Thorbecke (FGT) }\end{array}$ & Positivo & Significativo \\
\hline
\end{tabular}




\begin{tabular}{|c|c|c|c|c|c|c|c|}
\hline \multirow[b]{2}{*}{ Fonte } & \multirow[b]{2}{*}{ Amostra } & \multirow[b]{2}{*}{ Período } & \multirow{2}{*}{$\begin{array}{l}\text { Estrutura dos } \\
\text { Dados }\end{array}$} & \multicolumn{2}{|c|}{ Medidas } & \multicolumn{2}{|c|}{ Correlação } \\
\hline & & & & $\begin{array}{c}\text { Função alocativa e } \\
\text { distributiva }\end{array}$ & Função Desigualdade & Sinal & Significância \\
\hline $\begin{array}{l}\text { Araújo, } \\
\text { Alves e } \\
\text { Bessaria } \\
(2013)\end{array}$ & $\begin{array}{l}\text { Estados do } \\
\text { Brasil }\end{array}$ & $\begin{array}{l}2004- \\
2009\end{array}$ & $\begin{array}{l}\text { Painel efeitos } \\
\text { fixos }\end{array}$ & $\begin{array}{c}\text { Gastos em } \\
\text { educação, saúde e } \\
\text { bolsa-família }\end{array}$ & $\begin{array}{l}\text { Número de pessoas em } \\
\text { domicílios com renda } \\
\text { domiciliar per capita } \\
\text { inferior à linha de } \\
\text { extrema pobreza (ou } \\
\text { miséria), Número de } \\
\text { pessoas em domicílios } \\
\text { com renda domiciliar } \\
\text { per capita inferior à } \\
\text { linha de pobreza, } \\
\text { Coeficiente de Gini e } \\
\text { Coeficiente de Theil-T }\end{array}$ & $\begin{array}{l}\text { Negativamente } \\
\text { relacionados }\end{array}$ & $\begin{array}{c}\text { Significativo } \\
\text { apenas para os } \\
\text { indicadores e } \\
\text { pobreza. }\end{array}$ \\
\hline $\begin{array}{l}\text { Peña et alli } \\
\text { (2015) }\end{array}$ & $\begin{array}{c}\text { Estados do } \\
\text { Brasil }\end{array}$ & $\begin{array}{l}1999, \\
2003, \\
2005 \\
2009\end{array}$ & $\begin{array}{l}\text { Cadeia de } \\
\text { Markov }\end{array}$ & Bolsa-Família & $\begin{array}{l}\text { Renda per capta para } \\
\text { cada décimo da } \\
\text { população }\end{array}$ & $\begin{array}{l}\text { Os programas } \\
\text { transferência de rer } \\
\text { período (1999-2003) } \\
\text { impactar de maneir } \\
\text { pobreza. As tendênci } \\
\text { mostraram capazes } \\
\text { ciclo de pobreza, pc } \\
\text { redução das desigua } \\
\text { pobreza. }\end{array}$ & $\begin{array}{l}\text { nnamentais de } \\
\text { execução neste } \\
\text { insuficientes para } \\
\text { iva a redução da } \\
\text { eríodo 2005-09 se } \\
\text { ar a dinâmica do } \\
\text { ando que, com a } \\
\text { haja redução da }\end{array}$ \\
\hline
\end{tabular}

Fonte: Elaborado pelo autor. 


\subsubsection{Função Alocativa}

Observa-se no Quadro 8 que os estudos de Perotti (1996), Perroti, Lindert (1996), Gouveia e Masia (1998), Figini (1998), Bassett, Burkett e Putterman (1999), Panizza (1999), Rodriguez (1999), Tanninen (1999), Castronova (2001), Jha, Biswal e Biswal (2001), Sylwester (2002), De Melo e Tiongson (2006), Bergh e Fink (2008), Zhang (2008) e Holzner (2011), Araújo, Alves e Bessaria (2013) utilizaram gastos públicos, elementos da função alocativa, como tentativa de avaliar seu respectivo impacto sobre as desigualdades.

Das principais áreas da despesa utilizadas nestes estudos destacam-se as que segundo Musgrave e Musgrave (1980) geram externalidades positivas: educação e saúde. Essas variáveis constaram de forma explícita nos estudos de: Bassett, Burkett e Putterman (1999), Jha, Biswal e Biswal (2001), Sylwester (2002), De Mello e Tiongson (2006), Bergh e Fink (2008), Zhang (2008), Araújo, Alves e Bessaria (2013). Nos demais estudos, elas foram incluídas, mas não de forma destacada.

Diante do exposto, fica estabelecida a hipótese de pesquisa 1 - os estados com maior proporção de despesas nas áreas de educação e saúde reduziram a desigualdade de renda, coeteris paribus.

A CF/1988 estabelece que educação e saúde são direitos sociais assegurados a todos os cidadãos ${ }^{6}$.

A educação e saúde quando bem distribuídos e ofertados de forma igualitária tendem a garantir o mínimo social na medida em que garantem que todos tenham um padrão mínimo de bem-estar, na medida que visam reduzir a sensação de exclusão da sociedade causada por diferenças da renda, e na medida em que visa eliminar as vantagens desproporcionais na educação (COLWEEL, 2011).

\footnotetext{
${ }^{6}$ Art. $6^{\circ}$ São direitos sociais a educação, a saúde, a alimentação, o trabalho, a moradia, o transporte, o lazer, a segurança, a previdência social, a proteção à maternidade e à infância, a assistência aos desamparados, na forma desta Constituição (BRASIL, 1988).
} 


\subsubsection{Função Distributiva}

Por uma série de razões, a apropriação da renda e da riqueza se dá de forma diferenciada na sociedade e, na maioria dos casos, ela se apresenta de forma bastante concentrada. As forças do mercado, ao invés de amenizar este fato tendem a perpetuá-lo ou mesmo acentuá-lo. A função distributiva tem como principal objetivo utilizar mecanismos que visem ajustar a distribuição da renda e da riqueza na sociedade, tornandoa menos desigual possível, fazendo-a socialmente aceitável e economicamente funcional. Assim, podem-se utilizar mecanismos como: tributação com impostos progressivos, ou transferências de renda ou subsídios (MUSGRAVE; MUSGRAVE, 1980; REZENDE, 2001; GIACOMONI, 2012).

Para se compreender a importância dos impostos progressivos, objeto deste estudo, sobre as desigualdades, faz-se necessário introduzir alguns conceitos relacionados a eles.

Os impostos podem incidir sobre três bases tributárias: (i) impostos sobre a riqueza ou patrimônio: incidem sobre o estoque acumulado de capital; (ii) impostos sobre a renda: incidem sobre o fluxo de anual de rendimento; (iii) impostos sobre venda de mercadorias e serviços: incidem no momento da compra e venda (REZENDE, 2001).

Outra classificação dos impostos diz respeito à relação entre ônus do imposto e pagamento. Nem sempre o ônus do imposto recai sobre quem efetua o pagamento: aquele que recolhe o tributo aos cofres. Em determinadas circunstâncias quem efetua o pagamento consegue transferir o ônus dos impostos para terceiros. O Quadro 9 mostra a classificação quanto à relação entre o ônus e o pagamento do imposto.

Quadro 9 - Relação entre o ônus e o pagamento do imposto

\begin{tabular}{|c|l|l|}
\hline $\begin{array}{c}\text { Tipo de } \\
\text { Imposto }\end{array}$ & \multicolumn{1}{|c|}{ Característica } & \multicolumn{1}{|c|}{ Simplificação } \\
\hline Direto & $\begin{array}{l}\text { São os tributos em que os contribuintes são os } \\
\text { mesmos que arcam com o ônus da respectiva } \\
\text { contribuição. }\end{array}$ & $\begin{array}{l}\text { Tributos cuja base econômica seja } \\
\text { a renda ou patrimônio. }\end{array}$ \\
\hline Indireto & $\begin{array}{l}\text { São os tributos para os quais os contribuintes } \\
\text { poderiam transferir total ou parcialmente o ônus da } \\
\text { contribuição para terceiros. }\end{array}$ & $\begin{array}{l}\text { Tributos cuja base econômica é a } \\
\text { transação com mercadorias ou } \\
\text { serviço. }\end{array}$ \\
\hline
\end{tabular}

Fonte: Adaptado de Rezende (2001)

Por fim, outro critério de classificação dos impostos considera a capacidade contributiva. De acordo com este critério, os indivíduos deveriam, na medida de suas capacidades (medidas em termos de renda), colaborar para o financiamento dos gastos governamentais (REZENDE, 2001). 
Sob essa ótica, deve-se dar um mesmo tratamento, em termos de contribuição, aos indivíduos considerados iguais - equidade horizontal (tributação igual) - assegurando, ao mesmo tempo, que os desiguais sejam diferenciados segundo algum critério a ser estabelecido - equidade vertical (tributação proporcional) (REZENDE, 2001).

Considerando a equidade vertical, existem três tipos de impostos: (i) regressivo: quando o aumento na contribuição for menos que proporcional ao ocorrido na renda; (ii) proporcional: quando o aumento na contribuição é proporcional ao aumento na renda, a relação imposto/renda permanecerá constante para qualquer nível de renda; (iii) progressivo: quando o aumento na contribuição for mais que proporcional ao aumento na renda (REZENDE, 2001).

Quanto aos efeitos dos impostos progressivos sobre a desigualdade de renda, destacam-se os estudos de Perroti (1996), Partridge (1997), Figini (1998), Panizza (1999), De Mello e Tiongson (2006). Esses autores entendem que os impostos progressivos se constituem em um dos instrumentos legítimos para promover a função distributiva ao reduzir a desigualdade de renda. Não foram localizados estudos sobre os impostos progressivos e a desigualdade de renda no Brasil ${ }^{7}$.

A partir dos elementos até aqui apresentados, fica estabelecida a hipótese de pesquisa 2 - Os estados com maior proporção de impostos progressivos reduziram a desigualdade de renda, coeteris paribus.

Dados do estudo Carga Tributária no Brasil - 2014 (Análise por Tributo e Bases de Incidência) ${ }^{8}$ aponta que em 2013, do total da carga tributária brasileira, os tributos incidentes sobre a propriedade representam 1,3\%, sobre a renda, lucro, e ganho de capital $6,1 \%$, folha de salários $8,5 \%$ e sobre o bens e serviços $17,9 \%$ somando um carga tributária de 33,8\% sobre o PIB; enquanto a carga tributária nos países da Organização para a Cooperação e Desenvolvimento Econômico (OCDE) os tributos incidentes sobre a propriedade representam 1,9\%, sobre a renda, lucro, e ganho de capital 11,7\%, folha de salários 9,6\% e sobre o bens e serviços 11,5\%. Observa-se que há uma diferença estrutural entre o Brasil e os demais países, pois enquanto nestes a maior contribuição vem da renda, lucro e ganho de capital com 11,7\%, no Brasil a maior contribuição vem de bens e serviços $17,9 \%$, o que lhe dá a primeira posição no ranking da pesquisa.

\footnotetext{
${ }^{7}$ Foram realizadas buscas nas bases de pesquisas utilizando os termos: "impostos progressivos" e "desigualdade".

8 Disponível em http://idg.receita.fazenda.gov.br/dados/receitadata/estudos-e-tributarios-e-aduaneiros/estudos-eestatisticas/carga-tributaria-no-brasil/29-10-2015-carga-tributaria-2014.
} 
Assim, considerando esse contexto, existe a possibilidade a hipótese de pesquisa 2 fundamentada em estudos internacionais ter efeito contrário no Brasil.

Uma outra forma de reduzir a desigualdade seria por intermédio das transferências de renda. Conforme exposto, na seção 2.3.3, as transferências por cotas (revenue sharing) podem ter a finalidade redistributiva quando os recursos são repassados segundo critérios que: (i) guardam uma relação inversamente proporcional à renda e diretamente proporcional à população; ou (ou) relacionados a indicadores de carências associados à disponibilidade de bens públicos ou meritórios.

Estudos de Perotti (1994), Person e Tabellini (1994), Basset, Burkett e Putterman (1999), De Melo e Tiongson (2006), Rocha (2008a, 2008b), Ferraz (2008), Hoffmann (2010) Cavalcanti, Costa e Silva (2013), Araújo, Alves e Besarria (2013), Peña et alli (2015) consideram de forma geral que as transferências de renda contribuem para a redução da desigualdade de renda.

A partir destes últimos elementos, fica estabelecida a hipótese de pesquisa 3 - Os estados com maior proporção de transferências de renda direta não reduziram a desigualdade de renda, coeteris paribus.

No entanto, estudos de Marinho, Linhares e Campelo (2011), Lima, Moreira e Souza (2013), Lima e Moreira (2014) identificaram que as transferências do bolsa família não se mostraram eficientes na redução das desigualdades de renda. Assim, considerando esse contexto, existe a possibilidade a hipótese de pesquisa 2 fundamentada em estudos internacionais e alguns nacionais ter efeito contrário no Brasil.

\subsection{Peculiaridades dos instrumentos fiscais no Brasil}

Neste tópico serão apresentadas peculiaridades da federação brasileira que terão impactos na modelagem funcional e econométrica das hipóteses de pesquisa 1, 2 e 3 .

\subsubsection{Despesas com Educação e Saúde}

Nesta seção serão apresentadas as fontes de financiamento e os encargos relacionados à saúde e educação considerando o período do estudo: 1995 a 2012.

\subsubsection{Despesas com Manutenção e Desenvolvimento do Ensino (educação)}

A Constituição Federal de 1988 estabelece que: 
Art. 212. A União aplicará, anualmente, nunca menos de dezoito, $e$ os Estados, $\boldsymbol{o}$ Distrito Federal e os Municípios vinte e cinco por cento, no mínimo, da receita resultante de impostos, compreendida a proveniente de transferências, na manutenção e desenvolvimento do ensino.

$\S 1^{\circ}$ A parcela da arrecadação de impostos transferida pela União aos Estados, ao Distrito Federal e aos Municípios, ou pelos Estados aos respectivos Municípios, não é considerada, para efeito do cálculo previsto neste artigo, receita do governo que a transferir.

$\S 2^{\circ}$ Para efeito do cumprimento do disposto no "caput" deste artigo, serão considerados os sistemas de ensino federal, estadual e municipal e os recursos aplicados na forma do art. 213.

$\S 3^{\circ}$ A distribuição dos recursos públicos assegurará prioridade ao atendimento das necessidades do ensino obrigatório, no que se refere a universalização, garantia de padrão de qualidade e equidade, nos termos do plano nacional de educação. (Redação dada pela Emenda Constitucional no 59, de 2009)

$\S 4^{\circ}$ Os programas suplementares de alimentação e assistência à saúde previstos no art. 208, VII, serão financiados com recursos provenientes de contribuições sociais e outros recursos orçamentários.

$\S 5^{\circ}$ A educação básica pública terá como fonte adicional de financiamento a contribuição social do salário-educação, recolhida pelas empresas na forma da lei. (Redação dada pela Emenda Constitucional $n^{\circ} 53$, de 2006)

$\S 6^{\circ}$ As cotas estaduais e municipais da arrecadação da contribuição social do salário-educação serão distribuídas proporcionalmente ao número de alunos matriculados na educação básica nas respectivas redes públicas de ensino. (Incluído pela Emenda Constitucional $n^{\circ} 53$, de 2006) (grifo meu)

Observa-se inicialmente que todos os entes da Federação devem alocar recursos para custear despesas com manutenção e desenvolvimento do ensino. Além disso, a CF/1988 segrega as prioridades de atuação de cada ente.

Art. 211. A União, os Estados, o Distrito Federal e os Municípios organizarão em regime de colaboracão seus sistemas de ensino.

$\$ 1^{\circ}$ A União organizará o sistema federal de ensino e o dos Territórios, financiará as instituições de ensino públicas federais e exercerá, em matéria educacional,

função redistributiva e supletiva, de forma a garantir equalização de oportunidades educacionais e padrão mínimo de qualidade do ensino mediante assistência técnica e financeira aos Estados, ao Distrito Federal e aos Municípios; (Redação dada pela Emenda Constitucional no $n^{\circ}$, de 1996)

$\S 2^{\circ}$ Os Municípios atuarão prioritariamente no ensino fundamental e na educação infantil. (Redação dada pela Emenda Constitucional no $n^{\circ}$, de 1996)

$\S 3^{\circ}$ Os Estados e o Distrito Federal atuarão prioritariamente no ensino fundamental e médio. (Incluído pela Emenda Constitucional no 14, de 1996)

Diante do exposto, à luz da CF/1988 pode-se segregar o ensino em: infantil, fundamental, médio e superior. Dessas modalidades, tanto os Estados quanto os Municípios devem priorizar o ensino fundamental. 


\subsubsection{Despesas com Saúde}

A Constituição Federal de 1988 estabelece nos Atos das Disposições

Constitucionais Transitórias que ${ }^{9}$ :

Art. 77. Até o exercício financeiro de 2004, os recursos mínimos aplicados nas acões e serviços públicos de saúde serão equivalentes: (Incluído pela Emenda Constitucional $n^{\circ} 29$, de 2000)

I-no caso da União: (Incluído pela Emenda Constitucional $n^{\circ} 29$, de 2000)

a) no ano 2000, o montante empenhado em ações e serviços públicos de saúde no exercício financeiro de 1999 acrescido de, no mínimo, cinco por cento; (Incluído pela Emenda Constitucional $n^{\circ} 29$, de 2000)

b) do ano 2001 ao ano 2004, o valor apurado no ano anterior, corrigido pela variação nominal do Produto Interno Bruto - PIB; (Incluído pela Emenda Constitucional $n^{\circ} 29$, de 2000)

II - no caso dos Estados e do Distrito Federal, doze por cento do produto da arrecadacão dos impostos a que se refere o art. 155 e dos recursos de que tratam os arts. 157 e 159, inciso I, alínea a, e inciso II, deduzidas as parcelas que forem transferidas aos respectivos Municípios; e (Incluído pela Emenda Constitucional $n^{o}$ 29, de 2000)

III - no caso dos Municípios e do Distrito Federal, quinze por cento do produto da arrecadacão dos impostos a que se refere o art. 156 e dos recursos de que tratam os arts. 158 e 159, inciso I, alínea b e $\$ 3^{\circ}$. (Incluído pela Emenda Constitucional n ${ }^{\circ} 29$, de 2000)

$\S 1^{\circ}$ Os Estados, o Distrito Federal e os Municípios que apliquem percentuais inferiores aos fixados nos incisos II e III deverão elevá-los gradualmente, até o exercício financeiro de 2004, reduzida a diferença à razão de, pelo menos, um quinto por ano, sendo que, a partir de 2000, a aplicação será de pelo menos sete por cento. (Incluído pela Emenda Constitucional $n^{\circ} 29$, de 2000)

$\S 2^{\circ}$ Dos recursos da União apurados nos termos deste artigo, quinze por cento, no mínimo, serão aplicados nos Municípios, segundo o critério populacional, em ações e serviços básicos de saúde, na forma da lei. (Incluído pela Emenda Constitucional $n^{\circ} 29$, de 2000)

$\$ 3^{\circ}$ Os recursos dos Estados, do Distrito Federal e dos Municípios destinados às ações e serviços públicos de saúde e os transferidos pela União para a mesma finalidade serão aplicados por meio de Fundo de Saúde que será acompanhado e fiscalizado por Conselho de Saúde, sem prejuízo do disposto no art. 74 da Constituição Federal. (Incluído pela Emenda Constitucional n ${ }^{o} 29$, de 2000)

$\S 4^{\circ} \mathrm{Na}$ ausência da lei complementar a que se refere o art. 198, $\S 3^{\circ}$, a partir do exercício financeiro de 2005, aplicar-se-á à União, aos Estados, ao Distrito Federal e aos Municípios o disposto neste artigo. (Incluído pela Emenda Constitucional $n^{o}$ 29, de 2000).

\footnotetext{
${ }^{9}$ Em 2015 foi publicada emenda constitucional que fixou limite para União: Art. 198. [...]

$\S 2^{\circ}$ A União, os Estados, o Distrito Federal e os Municípios aplicarão, anualmente, em ações e serviços públicos de saúde recursos mínimos derivados da aplicação de percentuais calculados sobre: (Incluído pela Emenda Constitucional $n^{\circ} 29$, de 2000)

I - no caso da União, a receita corrente líquida do respectivo exercício financeiro, não podendo ser inferior a $15 \%$ (quinze por cento); (Redacão dada pela Emenda Constitucional $n^{\circ} 86$, de 2015)

II - no caso dos Estados e do Distrito Federal, o produto da arrecadação dos impostos a que se refere o art. 155 e dos recursos de que tratam os arts. 157 e 159, inciso I, alínea a, e inciso II, deduzidas as parcelas que forem transferidas aos respectivos Municípios; (Incluído pela Emenda Constitucional no 29, de 2000)

III - no caso dos Municípios e do Distrito Federal, o produto da arrecadação dos impostos a que se refere o art. 156 e dos recursos de que tratam os arts. 158 e 159, inciso I, alínea b e $\$ 3^{\circ}$. (Incluído pela Emenda Constitucional $n^{\circ} 29$, de 2000)
} 
Observa-se inicialmente que todos os entes da Federação devem alocar recursos para custear despesas em ações e serviços públicos de saúde. No caso das despesas com saúde, não há na legislação uma segregação de atribuições, tal qual ocorre nas despesas com educação.

\subsubsection{Receitas Coercitivas por Competências}

O Quadro 10 apresenta a estrutura atual das receitas coercitivas da federação brasileira: tributos e contribuições com as respectivas bases tributárias (renda, propriedade e consumo).

Das receitas citadas no Quadro 10 são consideradas incidentes sobre a propriedade e a renda: imposto sobre renda e proventos (IR), IOF (imposto sobre operações financeiras), imposto territorial rural (ITR), imposto sobre grandes fortunas (IGF) que são de competência da União; os impostos sobre transmissão causa mortis e doações (ITCMD) e imposto sobre veículos automotores (IPVA) que são de competência dos Estados; o imposto predial e territorial urbano (IPTU) e o imposto transmissão bens "inter vivos" (ITBI) que são de competência os Municípios. 
Quadro 10 - Sistema Tributário na CF/1988 atualizado

\begin{tabular}{|c|c|c|c|}
\hline \multirow{16}{*}{ Tributos } & \multirow{14}{*}{ Impostos } & \multirow{2}{*}{ Sobre Comércio Exterior } & Importação (U) \\
\hline & & & Exportação (U) \\
\hline & & \multirow{7}{*}{ Sobre a Propriedade e Renda } & Renda e proventos (U) \\
\hline & & & Territorial rural $(\mathrm{U})$ \\
\hline & & & Grandes fortunas (U) \\
\hline & & & Transmissão causa mortis e doações (E) \\
\hline & & & Veículos automotores (E) \\
\hline & & & Predial e territorial urbano $(\mathrm{M})$ \\
\hline & & & Transmissão bens "inter vivos" (M) \\
\hline & & \multirow{4}{*}{ Consumo } & Produtos industrializados $(\mathrm{U})$ \\
\hline & & & Sobre operações de crédito (U) \\
\hline & & & Sobre Circulação de Mercadorias (E) \\
\hline & & & Sobre serviços de qualquer natureza (M) \\
\hline & & Especiais & Extraordinários por motivo de guerra (U) \\
\hline & \multicolumn{3}{|c|}{ Taxas (U) (E) (M) } \\
\hline & \multicolumn{3}{|c|}{ Contribuições de melhoria (U) (E) (M) } \\
\hline \multirow{5}{*}{ Contribuições } & \multirow{4}{*}{ Sociais } & Cont & Previdenciárias (U) \\
\hline & & & Prognósticos (U) \\
\hline & & & ro Líquido (U) \\
\hline & & Financic & Seguridade Social (U) \\
\hline & Intervenção no Domínio Econômico & & stíveis (U) \\
\hline \multirow{3}{*}{ Fundos de Participação } & \multicolumn{3}{|c|}{ 21,5\% (vinte e um vírgula cinco por cento) do Imposto de Renda e do Imposto sobre Produtos Industrializados deve ser repassado aos Estados. } \\
\hline & \multicolumn{3}{|c|}{$\begin{array}{l}24,5 \% \text { (vinte e quatro vírgula cinco por cento) do Imposto de Renda e do Imposto sobre Produtos Industrializados deve ser repassado aos } \\
\text { Municípios. }\end{array}$} \\
\hline & \multicolumn{3}{|c|}{$\begin{array}{l}3 \% \text { do Imposto de Renda e do Imposto sobre Produtos Industrializados deve ser repassado aos Fundos Constitucionais do Norte, Nordeste e } \\
\text { Centro-Oeste. }\end{array}$} \\
\hline \multirow{5}{*}{$\begin{array}{l}\text { Outras Cotas } \\
\text { Constitucionais }\end{array}$} & \multicolumn{3}{|c|}{$\begin{array}{l}10 \% \text { (três por cento) do Imposto sobre Produtos Industrializados proporcionalmente ao valor das respectivas exportações de produtos } \\
\text { industrializados }\end{array}$} \\
\hline & \multicolumn{3}{|c|}{$50 \%$ (cinquenta por cento) do Imposto sobre os Propriedade de Veículos Automotores deve ser repassado aos Municípios. } \\
\hline & \multicolumn{3}{|c|}{$25 \%$ (vinte e cinco por cento) do Imposto sobre Circulação de Mercadorias deve ser repassado aos Municípios. } \\
\hline & \multicolumn{3}{|c|}{ 100\% (cem por cento) do IOF ouro é distribuído aos Estados (trinta por cento) e aos Municípios (setenta por cento). } \\
\hline & \multicolumn{3}{|c|}{$29 \%$ (vinte e nove por cento) da Contribuição da Intervenção no Domínio Econômico deve ser repassada aos Estados e Distrito Federal. } \\
\hline
\end{tabular}

Fonte: Brasil (1988).

Legenda: (U) Competência da União; (E) Competência dos Estados; (M) Competência dos Municípios 
Quanto ao caráter progressivo dos impostos, o ordenamento jurídico constitucional enquadra nessa situação os seguintes impostos: Imposto de Renda - IR, Imposto Territorial Rural - ITR, Imposto sobre Propriedade de Veículos Automotores IPVA e o Imposto sobre Propriedade Territorial Urbana - IPTU.

Sobre o IR e o ITR, a CF/1988 estabelece que:

Art. 153. Compete à União instituir impostos sobre:

[...]

III - renda e proventos de qualquer natureza;

$[\ldots]$

$V I$ - propriedade territorial rural;

$\S 2^{\circ}$ O imposto previsto no inciso III:

I - será informado pelos critérios da generalidade, da universalidade e da progressividade, na forma da lei.

[...]

$\S 4^{\circ}$ O imposto previsto no inciso VI do caput: (Redação dada pela Emenda Constitucional $n^{\circ} 42$, de 19.12.2003)

I - será progressivo e terá suas alíquotas fixadas de forma a desestimular a manutenção de propriedades improdutivas; (Incluído pela Emenda Constitucional $n^{o} 42$, de 19.12.2003). (grifo meu)

Sobre o IPVA, a CF/1998 estabelece que;

Art. 155. Compete aos Estados e ao Distrito Federal instituir impostos sobre:

[...]

III - propriedade de veículos automotores

$\S 6^{\circ}$ O imposto previsto no inciso III: (Incluído pela Emenda Constitucional $n^{\circ} 42$, de 19.12.2003)

I - terá alíquotas mínimas fixadas pelo Senado Federal; (Incluído pela Emenda Constitucional $n^{\circ} 42$, de 19.12.2003)

II - poderá ter alíquotas diferenciadas em função do tipo e utilização.(Incluído pela Emenda Constitucional $n^{\circ}$ 42, de 19.12.2003). (grifo meu)

Sobre o IPTU, a CF/1988 estabelece que:

Art. 156. Compete aos Municípios instituir impostos sobre:

I - propriedade predial e territorial urbana; [...]

$\S 1^{\circ}$ Sem prejuízo da progressividade no tempo a que se refere o art. $182, \S 4^{\circ}$, inciso

II, o imposto previsto no inciso I poderá: (Redação dada pela Emenda Constitucional $n^{\circ} 29$, de 2000)

I - ser progressivo em razão do valor do imóvel; e (Incluído pela Emenda Constitucional $n^{\circ} 29$, de 2000)

II - ter alíquotas diferentes de acordo com a localização e o uso do imóvel. (grifo meu)

Assim, estes quatro impostos citados são mais elevados para os indivíduos que possuem mais renda, mais propriedades em regiões consideradas nobres ou veículos com preços mais elevados. Essa fonte de recurso seria um dos pilares para promover a distribuição de renda proposta pela função distributiva. 
Por fim, existem dois impostos que incidem sobre a transferência de bens e propriedades: Imposto sobre Transmissão de Bens Causa Mortis e Doações - ITCMD (sendo este incidente sobre as heranças que seria outra forma de promover a distribuição de renda) e o Imposto de Transmissão Bens Intervivos - ITBI.

Quanto ao ITCMD, o Supremo Tribunal Federal (STF) decidiu no Recurso Extraordinário 562.045 que o mesmo pode ter caráter progressivo, bem como de que não haveria necessidade de se estabelecer emenda constitucional para essa eficácia. Além disso, a resolução do Senado n ${ }^{\circ} 9$ de 5 de maio de 1992 estabelece que:

Art. $2^{\circ}$ As alíquotas dos Impostos, fixadas em lei estadual, poderão ser progressivas em função do quinhão que cada herdeiro efetivamente receber, nos termos da Constituição Federal (grifo meu).

O ITBI não pode ser progressivo conforme consta na súmula 656 do Supremo Tribunal Federal (STF):

É inconstitucional a lei que estabelece alíquotas progressivas para o imposto de transmissão inter vivos de bens imóveis - ITBI com base no valor venal do imóvel.

Diante de todo o exposto, pode ser incorporado na análise como imposto progressivo o ITCMD. O ITBI será incorporado por incidir sobre as propriedades, em que pese não ser progressivo juridicamente.

\subsubsection{Transferências de Renda Diretas}

Nas seções 2.3.3 e 2.4.2 observou-se que as transferências de renda podem ser uma das formas de materializar a função distributiva. Considerando o período de estudo e os instrumentos de planejamento no âmbito federal denominados planos plurianuais publicados no período, realizou-se um levantamento das transferências de renda entre 1995 e 2012, chegando-se ao resultado disposto no Quadro 11.

Inicialmente é importante esclarecer que tais programas possuem como públicoalvo a sociedade como um todo, mas especialmente pessoas (crianças, adolescentes ou idosos) ou famílias que estejam com renda abaixo do definido. 
Quadro 11 - Programas de transferências de renda relacionadas com a assistência social no âmbito da União entre 1995 e 2012

\begin{tabular}{|c|c|c|}
\hline $\begin{array}{l}\text { Instrumento de } \\
\text { Planejamento }\end{array}$ & $\begin{array}{c}\text { Programas de Transferências de Renda } \\
\text { Direta }^{\text {a }}\end{array}$ & Principal Benefício \\
\hline \multirow{3}{*}{$\begin{array}{l}\text { Plano Plurianual } \\
\text { 2012-2015 }\end{array}$} & Programa Bolsa Família & Bolsa Família \\
\hline & $\begin{array}{l}\text { Programa Fortalecimento do Sistema } \\
\text { Único de Assistência Social (SUAS) }\end{array}$ & $\begin{array}{l}\text { Benefício de Prestação Continuada } \\
\text { da Assistência Social }\end{array}$ \\
\hline & $\begin{array}{l}\text { Promoção dos Direitos de Crianças e } \\
\text { Adolescentes }\end{array}$ & $\begin{array}{l}\text { Concessão de Bolsa para Crianças } \\
\text { e Adolescentes em Situação de } \\
\text { Trabalho }\end{array}$ \\
\hline \multirow{3}{*}{$\begin{array}{l}\text { Plano Plurianual } \\
\text { 2008-2011 }\end{array}$} & $\begin{array}{llcc}\text { Transferência de } & \text { Renda } & \text { com } \\
\text { Condicionalidades } & - \text { Bolsa Família } & \\
\end{array}$ & Bolsa Família \\
\hline & Proteção Social Especial & $\begin{array}{l}\text { Benefício de Prestação Continuada } \\
\text { da Assistência Social }\end{array}$ \\
\hline & Erradicação do Trabalho Infantil & $\begin{array}{l}\text { Concessão de Bolsa para Crianças } \\
\text { e Adolescentes em Situação de } \\
\text { Trabalho }\end{array}$ \\
\hline \multirow{3}{*}{$\begin{array}{l}\text { Plano Plurianual } \\
\text { 2004-2007 }\end{array}$} & $\begin{array}{lll}\text { Transferência de } & \text { Renda } & \text { com } \\
\text { Condicionalidades } & \text { - Bolsa Família } & \\
\end{array}$ & Bolsa Família \\
\hline & Proteção Social Básica & $\begin{array}{l}\text { Benefício de Prestação Continuada } \\
\text { da Assistência Social }\end{array}$ \\
\hline & Erradicação do Trabalho Infantil & $\begin{array}{l}\text { Concessão de Bolsa para Crianças } \\
\text { e Adolescentes em Situação de } \\
\text { Trabalho }\end{array}$ \\
\hline \multirow{5}{*}{$\begin{array}{l}\text { Plano Plurianual } \\
\text { 2000-2003 }\end{array}$} & \multirow{3}{*}{$\begin{array}{l}\text { Enfrentamento à pobreza (Programa } \\
\text { Nacional de Renda Mínima vinculada à } \\
\text { Educação) }\end{array}$} & Concessão do Bolsa Escola \\
\hline & & Concessão do Bolsa Alimentação $^{b}$ \\
\hline & & Concessão do Auxílio Gás ${ }^{\text {b }}$ \\
\hline & Assistência Social & $\begin{array}{l}\text { Benefício de Prestação Continuada } \\
\text { da Assistência Social }\end{array}$ \\
\hline & Erradicação do Trabalho Infantil & $\begin{array}{l}\text { Concessão de Bolsa Criança- } \\
\text { Cidadã }\end{array}$ \\
\hline \multirow{2}{*}{$\begin{array}{l}\text { Plano Plurianual } \\
1996-1999\end{array}$} & Assistência Social & $\begin{array}{l}\text { Benefício de Prestação Continuada } \\
\text { da Assistência Social }\end{array}$ \\
\hline & Erradicação do Trabalho Infantil & $\begin{array}{l}\text { Concessão de } \\
\text { Cidadãa }^{c}\end{array}$ \\
\hline $\begin{array}{c}\text { Plano Plurianual } \\
1992-1995 \\
\end{array}$ & Proteção Social & $\begin{array}{l}\text { Benefício de Prestação Continuada } \\
\text { da Assistência Social d, e }\end{array}$ \\
\hline
\end{tabular}

Fonte: Elaborado pelo autor

Legenda: ${ }^{a}$ utilizou-se como dado de busca separadamente as palavras: transferência, renda, direta e assistência social. b instituído como programa em 2001. c instituído como programa em 1996. d regulamentado pela Lei Orgânica da Assistência Social - LOAS, Lei $n^{\circ}$ 8.742, de 7/12/1993. ${ }^{\mathrm{e}}$ Idosos a partir de 67 anos e portadores de deficiência com renda per capita inferior a um quarto de salário mínimo.

Estudos mais recentes normalmente utilizaram como variáveis de transferências de renda apenas o programa bolsa família. Essa decisão inicialmente reduz o período de análise (iniciando a contar de 2004) e ignora as demais transferências de renda existentes.

Enquadram-se nessa situação os estudos de Rocha (2004, 2008a), Kakwani, Neri e Son (2006), Medeiros, Brito e Soares (2007), Costa, Savato e Diniz (2008), Ferraz (2008), Tavares et alli, Oliveira, Zabot e Schneider (2009), Kerstenetzky (2009), Hoffmann (2010) Cavalcanti, Costa e Silva (2013), Araújo, Alves e Besarria, Cássio da Nóbrega (2013), Vaz (2013), Peña et alli (2015). 
Alguns estudos de como de Soares et alli (2006) e Rocha (2008b) consideraram também o Benefício de Prestação Continuada da Assistência Social.

\subsection{O Fator Eficiência}

A eficiência na perspectiva do indivíduo deve ser vista em termos de comportamento intencional de pessoas, mais especificamente, se esse comportamento é consistente com a realização dos propósitos e objetivos que estão sendo perseguidos (CORDATO, 1980).

Considerando a sociedade como uma composição de numerosos indivíduos, podese assumir que: (i) cada indivíduo é visto como uma seleção independente de programa de metas; (ii) cada indivíduo adota seu próprio curso de ação para alcançar seus objetivos. Assim, é irrealista falar de sociedade como uma única unidade em busca de alocar recursos de forma a refletir fielmente "a sua" dada hierarquia de objetivos. Sociedade não tem uma mente única, em que os objetivos de indivíduos diferentes podem classificados em uma única escala (CORDATO, 1980).

Deste modo, a eficiência de um sistema social corresponde à eficiência com que este sistema permite que seus membros individuais atinjam seus vários objetivos (CORDATO, 1980).

No âmbito brasileiro, a CF/1988 introduziu a eficiência como princípio da administração pública:

Art. 37. A administração pública direta e indireta de qualquer dos Poderes da União, dos Estados, do Distrito Federal e dos Municípios obedecerá aos princípios de legalidade, impessoalidade, moralidade, publicidade e eficiência e, também, ao seguinte: [...] (grifo meu)

Em se tratando de políticas públicas, o Estado pode ofertar por meio de seus programas de governo produtos ou serviços diretamente aos cidadãos como forma de permitir que eles obtenham instrumentos capazes de lhes dar condições melhores de vida. Esses programas de governo são conhecidos como programas finalísticos na doutrina ou como temáticos no âmbito do governo federal brasileiro.

Estudos sobre eficiência no setor público vêm se tornando comuns no âmbito internacional e nacional. O Quadro 12 mostra estudos quantitativos mais recentes sobre eficiência no setor público. 
Considerando os resultados dos estudos e presumindo-se que os entes que forem mais eficientes na alocação de recursos possuem melhor desempenho na redução da desigualdade de renda, ficam estabelecidas as seguintes hipóteses de pesquisa:

Hipótese de pesquisa 4 - Os estados mais eficientes na alocação de recursos financeiros para geração de produtos e serviços nas áreas de educação e saúde reduziram a desigualdade de renda, coeteris paribus.

Hipótese de pesquisa 5 - Os estados mais eficientes na oferta de produtos ou serviços para geração de resultados nas áreas de educação e saúde reduziram a desigualdade de renda, coeteris paribus.

Hipótese de pesquisa 6 - Os estados mais eficientes na arrecadação dos impostos progressivos reduziram a desigualdade de renda, coeteris paribus.

As hipóteses 4 e 5 estão relacionadas com a hipótese 1, enquanto a hipótese 6 está relacionada com a hipótese 2 . A hipótese 4 está relacionada a eficiência dos inputs financeiros e a hipótese 5 está relacionada a eficiência dos inputs físicos. A hipótese 6 está relacionada à eficiência da geração de receitas. Não foi possível aplicar o fator eficiência para a hipótese 3 a fim de se desenvolver uma nova hipótese. 
Quadro 12 - Estudos quantitativos recentes sobre eficiência no setor público

\begin{tabular}{|c|c|c|c|c|}
\hline Autor (es) & Método de análise & Objeto de Estudo & $\begin{array}{c}\text { Insumos (Inputs) e Produtos } \\
\text { (outputs) }\end{array}$ & Conclusões \\
\hline $\begin{array}{l}\text { Afonso e } \\
\text { Aubyn } \\
(2005)\end{array}$ & $\begin{array}{c}\text { Free Disposable Hull } \\
\text { (FDH) e Data } \\
\text { Envelopment Analysis } \\
\text { (DEA) }\end{array}$ & $\begin{array}{l}\text { Avaliação da eficiência } \\
\text { na saúde e educação em } \\
24 \text { países da OCDE } \\
\text { considerando dados de } \\
2003\end{array}$ & $\begin{array}{l}\text { Educação: } \\
\text {-Horas por ano na escola (in); } \\
\text {-Professores a cada } 100 \text { alunos (in); } \\
\text {-Teste de PISA (Programme for } \\
\text { International Student Assessment) (out). } \\
\text { Saúde: } \\
\text {-Médicos (in); } \\
\text {-Enfermeiros (in); } \\
\text {-Leitos hospitalares (in); } \\
\text {-Expectativa de vida (out); } \\
\text {-Índice de sobrevivência infantil (out). }\end{array}$ & $\begin{array}{l}\text { No âmbito da educação: Coreia do Sul, } \\
\text { Suécia, Japão e Finlândia foram } \\
\text { considerados eficientes. } \\
\text { No âmbito da saúde: Coreia do Sul, Suécia, } \\
\text { Japão, Finlândia, Portugal, Reino Unido, } \\
\text { Estados Unidos da América foram } \\
\text { considerados eficientes. } \\
\text { O método DEA é mais conservador que o } \\
\text { método FDH. }\end{array}$ \\
\hline $\begin{array}{l}\text { Afonso, } \\
\text { Schuknecht } \\
\text { e Tanzi } \\
(2005)\end{array}$ & FDH & $\begin{array}{c}23 \text { países industrializados } \\
\text { da OCDE considerando } \\
\text { dados entre os anos de } \\
1990 \text { e } 200 .\end{array}$ & $\begin{array}{l}\text {-Gasto (in); } \\
\text {-Corrupção (out); } \\
\text {-Burocracia (out); } \\
\text {-Qualidade do judiciário (out); } \\
\text {-Economia informal (out); } \\
\text {-Taxa de matrícula no secundário (out); } \\
\text { - Educação em ciências e matemática (out); } \\
\text {-Mortalidade infantil (out); } \\
\text {-Expectativa de vida ao nascer (out); } \\
\text { - Participação na renda das famílias 40\% } \\
\text { mais pobres (out); } \\
\text {-Estabilidade no crescimento do PIB (out); } \\
\text {-Inflação média (out); } \\
\text {-PIB per capita (out); } \\
\text {-Crescimento do PIB (out); } \\
\text {-Desemprego (out). }\end{array}$ & $\begin{array}{l}\text { Os países com "pequena" participação do } \\
\text { setor público no PIB apresentaram melhor } \\
\text { desempenho econômico, enquanto que } \\
\text { países com "grande" participação } \\
\text { apresentaram distribuição de renda mais } \\
\text { igualitária. Identificou-se que } 15 \text { países da } \\
\text { União Europeia estão gastando } 27 \% \text { a mais } \\
\text { do que os países "mais eficientes" }\end{array}$ \\
\hline
\end{tabular}




\begin{tabular}{|c|c|c|c|c|}
\hline Autor (es) & Método de análise & Objeto de Estudo & $\begin{array}{c}\text { Insumos (Inputs) e Produtos } \\
\text { (outputs) }\end{array}$ & Conclusões \\
\hline $\begin{array}{l}\text { Sousa, } \\
\text { Cribari- } \\
\text { Neto e } \\
\text { Stosic } \\
(2005)\end{array}$ & $\begin{array}{l}\text { DEA combinado com } \\
\text { "bootstrap" e } \\
\text { "jackknife" }\end{array}$ & $\begin{array}{l}4755 \text { municípios do } \\
\text { Brasil considerando } \\
\text { dados de } 2005\end{array}$ & $\begin{array}{l}\text {-Gasto corrente (in); } \\
\text {-Número de professores (in); } \\
\text {-Taxa de mortalidade infantil (in); } \\
\text {-Serviços hospitalares e de saúde (in); } \\
\text {-População total residente (out); } \\
\text {-População alfabetizada (out); } \\
\text {-Matrícula por escola (out); } \\
\text {-Estudantes que frequentam escola (out); } \\
\text {-Estudantes aprovados por escola (out); } \\
\text {-Estudantes no ano correto (out); } \\
\text {-Domicílios com acesso a água potável, a } \\
\text { esgoto e a coleta de lixo (out). }\end{array}$ & $\begin{array}{l}\text { O efeito regional mostrou-se estatisticamente } \\
\text { significativo, enquanto as capitais mostram-se mais } \\
\text { eficientes. } \\
\text { As comunidades localizadas nas áreas de seca } \\
\text { (Polígono das Secas) tendem a ser menos eficientes } \\
\text { do que os seus homólogos de áreas mais amenas, } \\
\text { portanto, mostrando que é mais difí́il para estas } \\
\text { cidades, que são assoladas por condições climáticas } \\
\text { adversas, para suprir adequadamente os serviços } \\
\text { públicos. } \\
\text { Os achados sugerem ainda que a recente } \\
\text { proliferação de pequenos municípios no Brasil não } \\
\text { leva a um uso eficiente dos recursos públicos. Seus } \\
\text { tamanhos pequenos os impede de se beneficiar das } \\
\text { economias de escala inerentes à produção de } \\
\text { serviços públicos e, como consequência, eles } \\
\text { tendem a operar com custos médios mais elevados, } \\
\text { gerando desperdício de recursos. } \\
\text { Entre os municípios muito pobres, aqueles que } \\
\text { participam no Programa Alvorada tendem a ser } \\
\text { mais eficientes, portanto, indicando que uma } \\
\text { melhor gestão poderia ser um subproduto deste } \\
\text { programa. Finalmente, os municípios que recebem } \\
\text { royalties substanciais receitas tendem a ser menos } \\
\text { eficientes, em seguida, o que sugere que as receitas } \\
\text { extraordinárias, em vez de incentivar a utilização } \\
\text { ótima dos recursos, parece em vez de contribuir } \\
\text { para um relaxamento das restrições fiscais e ao } \\
\text { aumento da ineficiência. A principal conclusão é } \\
\text { que maiores receitas dessa natureza em vez de } \\
\text { promover a eficiênncia, medida pelo acesso aos } \\
\text { serviços públicos - pode levar a restrições } \\
\text { orçamentárias relaxado e comportamento } \\
\text { perdulário. }\end{array}$ \\
\hline
\end{tabular}




\begin{tabular}{|c|c|c|c|c|}
\hline Autor (es) & Método de análise & Objeto de Estudo & $\begin{array}{c}\text { Insumos (Inputs) e Produtos } \\
\text { (outputs) }\end{array}$ & Conclusões \\
\hline $\begin{array}{c}\text { Herrera e } \\
\text { Pang (2005) }\end{array}$ & DEA, FDH e tobit & $\begin{array}{c}140 \text { países considerando } \\
\text { dados entre os anos de } 1996 \\
\text { e } 2002 \text { nas áreas de saúdes e } \\
\text { educação }\end{array}$ & $\begin{array}{l}\text { Educação } \\
\text { - Gasto público em educação per capita (in); } \\
\text {-Taxa de analfabetismo (\% de pessoas com } \\
\text { idade superior a } 15 \text { anos) (out); } \\
\text {-Razão professor - aluno (out); } \\
\text {-Matrículas no ensino primário e no ensino } \\
\text { secundário (out); } \\
\text {-Taxa de analfabetismo (\% de pessoas com } \\
\text { idade entre } 15 \text { e } 24 \text { anos) (out); } \\
\text {-Número médio de anos na escola (out); } \\
\text {-Primeiro grau completo (15 anos ou mais) } \\
\text { (out); } \\
\text {-Segundo grau completo (15 anos ou mais) } \\
\text { (out). } \\
\text { Saúde } \\
\text {-Gastos públicos em saúde per capita (in); } \\
\text {-Imunização contra difteria, coqueluche e } \\
\text { tétano (out); } \\
\text {-Imunização contra o sarampo (out); } \\
\text { - Expectativa de vida ajustada - índice que } \\
\text { leva em conta mortalidade e doença (out). }\end{array}$ & $\begin{array}{l}\text { Os resultados da primeira etapa (DEA e FDH) } \\
\text { mostram que os países mais ineficientes } \\
\text { poderiam produzir aproximadamente o mesmo } \\
\text { nível de outputs que consumiram cerca de } 50 \text { por } \\
\text { cento menos de inputs. } \\
\text { Em uma "segunda fase" do papel verificada } \\
\text { associação estatística entre os escores de } \\
\text { eficiência e variáveis ambientais que não estão } \\
\text { sob o controle das unidades de tomada de } \\
\text { decisão. } \\
\text { Na segunda etapa, os resultados mostraram: (i) } \\
\text { uma associação negativa entre o tamanho da } \\
\text { despesa e os escores de eficiência; (ii) uma } \\
\text { associação negativa entre a percentagem da } \\
\text { massa salarial no orçamento os escores de } \\
\text { eficiência; (iii) uma associação negativa entre a } \\
\text { proporção do serviço que é financiada } \\
\text { publicamente e os escores de eficiência; (iv) uma } \\
\text { associação positiva entre urbanização e os } \\
\text { escores de eficiência; (v) uma associação } \\
\text { negativa do HIV/AIDS os escores de eficiência } \\
\text { em saúde; (vi) uma associação negativa da } \\
\text { desigualdade de renda o os escores de eficiênncia } \\
\text { da educação; (vii) uma associação negativa entre } \\
\text { a ajuda-financiamento externo e os escores de } \\
\text { eficiência. }\end{array}$ \\
\hline $\begin{array}{l}\text { Sutherland, } \\
\text { Price, } \\
\text { Joumard e } \\
\text { Nicq (2006) }\end{array}$ & $\begin{array}{l}\text { DEA e Stochastic frontier } \\
\text { analysis (SFA) }\end{array}$ & $\begin{array}{l}\text { Avaliação da eficiência da } \\
\text { educação primária e } \\
\text { secundária em } 32 \text { países da } \\
\text { OCDE considerando dados } \\
\text { de } 2003\end{array}$ & $\begin{array}{l}\text {-Índice professor por aluno (in); } \\
\text {-Disponibilidade de computadores (in); } \\
\text {-Origem socioeconômica do aluno (in); } \\
\text {-Origem da linguagem (in); } \\
\text {-Teste de PISA (out). }\end{array}$ & $\begin{array}{l}\text { Os resultados sugerem que um papel importante } \\
\text { da origem socioeconômica do estudante na } \\
\text { determinação do desempenho nos testes do } \\
\text { PISA. O desempenho dos alunos também } \\
\text { aumenta com o número de professores, embora } \\
\text { com retornos decrescentes. }\end{array}$ \\
\hline
\end{tabular}




\begin{tabular}{|c|c|c|c|c|}
\hline Autor (es) & Método de análise & Objeto de Estudo & $\begin{array}{c}\text { Insumos (Inputs) e Produtos } \\
\text { (outputs) }\end{array}$ & Conclusões \\
\hline $\begin{array}{l}\text { Ribeiro e } \\
\text { Rodrigues } \\
\text { Júnior } \\
(2006)\end{array}$ & $\begin{array}{l}\text { FDH: replicaram o } \\
\text { estudo de Afonso, } \\
\text { Schuknecht e Tanzi } \\
\text { (2005) com nova } \\
\text { amostra }\end{array}$ & $\begin{array}{c}\text { Avaliação de } 21 \text { países da } \\
\text { América Latina }\end{array}$ & $\begin{array}{l}\text {-Despesa na respectiva área do gasto (in); } \\
\text {-Pagamentos irregulares relacionados a } \\
\text { decisões judiciais favoráveis (out); } \\
\text {-Frequência de pagamentos adicionais ou } \\
\text { propinas nos últimos } 3 \text { anos (out); } \\
\text { - Regulações administrativas (out); } \\
\text { - Independência do judiciário em relação ao } \\
\text { governo (out); } \\
\text { - Eficiência do conjunto de leis (out); } \\
\text { - Porcentagem de negócios não-oficiais } \\
\text { (out); } \\
\text { - Qualidade da educação em ciências e } \\
\text { matemática (out); } \\
\text { - Taxa líquida de matriculados no ensino } \\
\text { secundário (out); } \\
\text {-Expectativa de vida ao nascer em anos } \\
\text { (out); } \\
\text {-Taxa de mortalidade infantil (por 1000 } \\
\text { nascimentos) (no cálculo do indicador, foi } \\
\text { utilizada a "taxa de sobrevivência infantil = } \\
\text { 1000 - Taxa de mortalidade infantill) (out); } \\
\text { - Desvio-Padrão da taxa de crescimento do } \\
\text { PIB real no período 1996-2003 (No cálculo } \\
\text { do indicador, foi utilizado o inverso do } \\
\text { desvio-padrão) (out); } \\
\text { - Média da taxa de inflação no período } \\
\text { 1996-2003 (No cálculo do indicador, foi } \\
\text { utilizado o inverso) (out); } \\
\text {-Média da taxa de crescimento do PIB real } \\
\text { no período 1996-2003 (out); } \\
\text {-Média da taxa de desemprego no período } \\
\text { 1996-2003 (no cálculo do indicador, foi } \\
\text { utilizado o inverso) (out). }\end{array}$ & $\begin{array}{l}\text { No caso do Brasil, tem-se um resultado } \\
\text { direto. O país poderia economizar em torno } \\
\text { de } 40 \% \text { de seus insumos para produzir o } \\
\text { mesmo output. }\end{array}$ \\
\hline
\end{tabular}




\begin{tabular}{|c|c|c|c|c|}
\hline Autor (es) & Método de análise & Objeto de Estudo & $\begin{array}{c}\text { Insumos (Inputs) e Produtos } \\
\text { (outputs) }\end{array}$ & Conclusões \\
\hline $\begin{array}{l}\text { Souza } \\
\text { Júnior e } \\
\text { Gasparini } \\
(2006)\end{array}$ & DEA & $\begin{array}{c}\text { Avaliação da distribuição } \\
\text { ótima de recursos dos } 26 \\
\text { estados da federação } \\
\text { inclusive o DF } \\
\text { considerando dados de } \\
2002 \text { ou de } 2003 \\
\text { conforme o indicador. } \\
\text { Foram aplicados } 3 \\
\text { modelos antes de se } \\
\text { alcançar a distribuição } \\
\text { ótima. }\end{array}$ & 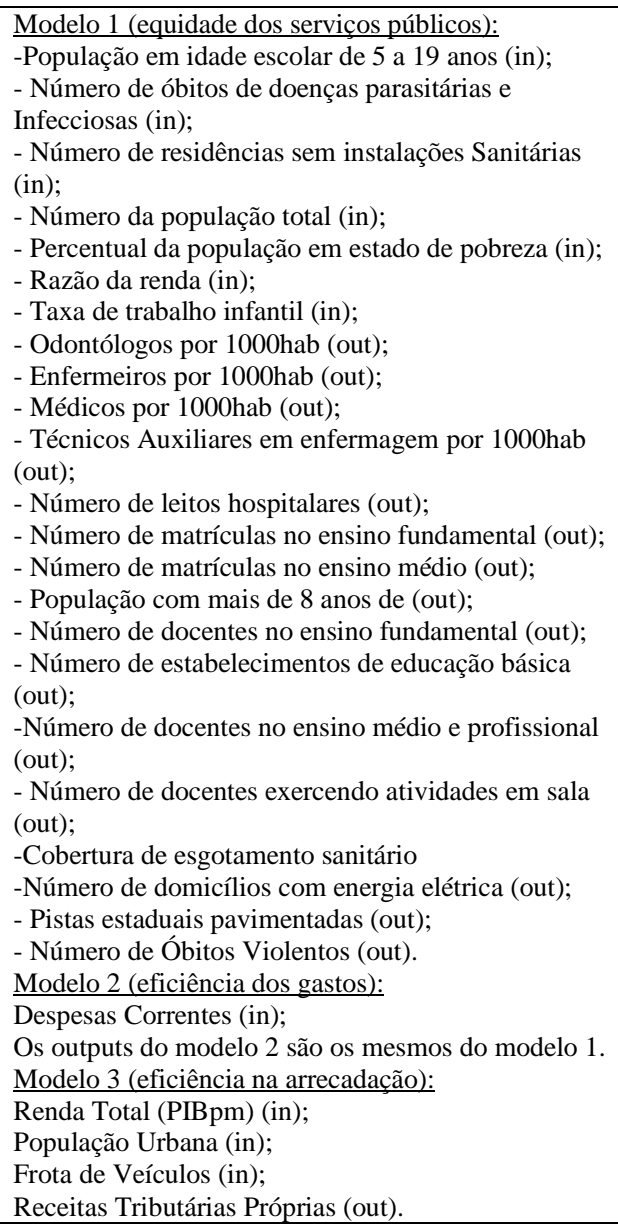 & $\begin{array}{l}\text { Observou-se que todos os } \\
\text { brasileiros necessitariam } \\
\text { transferências compensatórias. A Região } \\
\text { Nordeste apresentou a situação menos } \\
\text { favorável, significando maior necessidade } \\
\text { de receber transferências proporcionais ao } \\
\text { PIB. Em seguida vêm as Regiões Norte, } \\
\text { Centro-Oeste, Sudeste e Sul. Observa-se, } \\
\text { também, que os repasses de verbas do Fundo } \\
\text { de Participação dos Estados não foram } \\
\text { suficientes para equilibrar o nível de } \\
\text { serviços entre os Estados brasileiros. Em } \\
\text { contrapartida, há indícios de desperdícios de } \\
\text { recursos públicos justamente nas regiões que } \\
\text { deveriam ser mais favorecidas. }\end{array}$ \\
\hline
\end{tabular}




\begin{tabular}{|c|c|c|c|c|}
\hline Autor (es) & Método de análise & Objeto de Estudo & $\begin{array}{c}\text { Insumos (Inputs) e Produtos } \\
\text { (outputs) }\end{array}$ & Conclusões \\
\hline $\begin{array}{l}\text { Miranda } \\
\text { (2006) }\end{array}$ & DEA & $\begin{array}{c}\text { Avaliação de } 3206 \\
\text { municípios brasileiros } \\
\text { considerando dados de } \\
2000\end{array}$ & $\begin{array}{l}\text { - Despesas em educação, saúde e } \\
\text { urbanismo (in); } \\
\text { - Número de crianças matriculadas no } \\
\text { ensino básico em escolas municipais } \\
\text { (out); } \\
\text { - Número de domicílios servidos com } \\
\text { coleta de lixo (out); } \\
\text { - Número de internações hospitalares } \\
\text { em hospitais da rede municipal (out). }\end{array}$ & $\begin{array}{l}\text { A partir de comparações entre os resultados } \\
\text { agregados dos modelos CCR e BCC, foi } \\
\text { detectado um desperdício de } 50,6 \text { bilhões de } \\
\text { reais, quando o modelo CCR foi utilizado. } \\
\text { Tal número corresponde a 70,5\% da despesa } \\
\text { orçamentária dos municípios estudados. O } \\
\text { desperdício cai para } 34 \text { bilhões de reais } \\
\text { quando os efeitos de escala são considerados } \\
\text { (modelo BCC). Detectou-se ainda que } \\
\text { grande parte do desperdício acontece nos } \\
\text { municípios de menor população. }\end{array}$ \\
\hline $\begin{array}{l}\text { Brunet, } \\
\text { Borges e } \\
\text { Bertê } \\
(2006)\end{array}$ & $\begin{array}{l}\text { FDH com ajuste pela } \\
\text { função de Hill }\end{array}$ & $\begin{array}{l}26 \text { Estados do Brasil nas } \\
\text { funções legislativa, } \\
\text { judiciária e essencial à } \\
\text { justiça, segurança } \\
\text { pública, saúde, educação } \\
\text { e cultura, habitação, } \\
\text { agricultura, indústria, } \\
\text { comércio e serviços, } \\
\text { energia, transporte, } \\
\text { trabalho. }\end{array}$ & $\begin{array}{l}\text { Despesa média per capita entre } 2002 \text { e } \\
2004 \text { na respectiva função (in) } \\
\text { Legislativa } \\
\text {-Número de deputados estaduais por } \\
\text { 100mil habitantes (output); } \\
\text {-Número de projetos apreciados por } \\
\text { deputado estadual (outcome). } \\
\text { Judiciária e essencial à justiça } \\
\text {-Número de juízes estaduais, de } \\
\text { desembargadores e de juizados especiais } \\
\text { por 100mil habitantes (outputs); } \\
\text {-Percentual de casos julgados na justiça } \\
\text { comum de } 1^{\circ} \text { e em TJ estaduais } \\
\text { (outcome); } \\
\text {-Percentual de casos julgados nos } \\
\text { juizados especiais (outcome). } \\
\text { Segurança Pública }\end{array}$ & \\
\hline
\end{tabular}




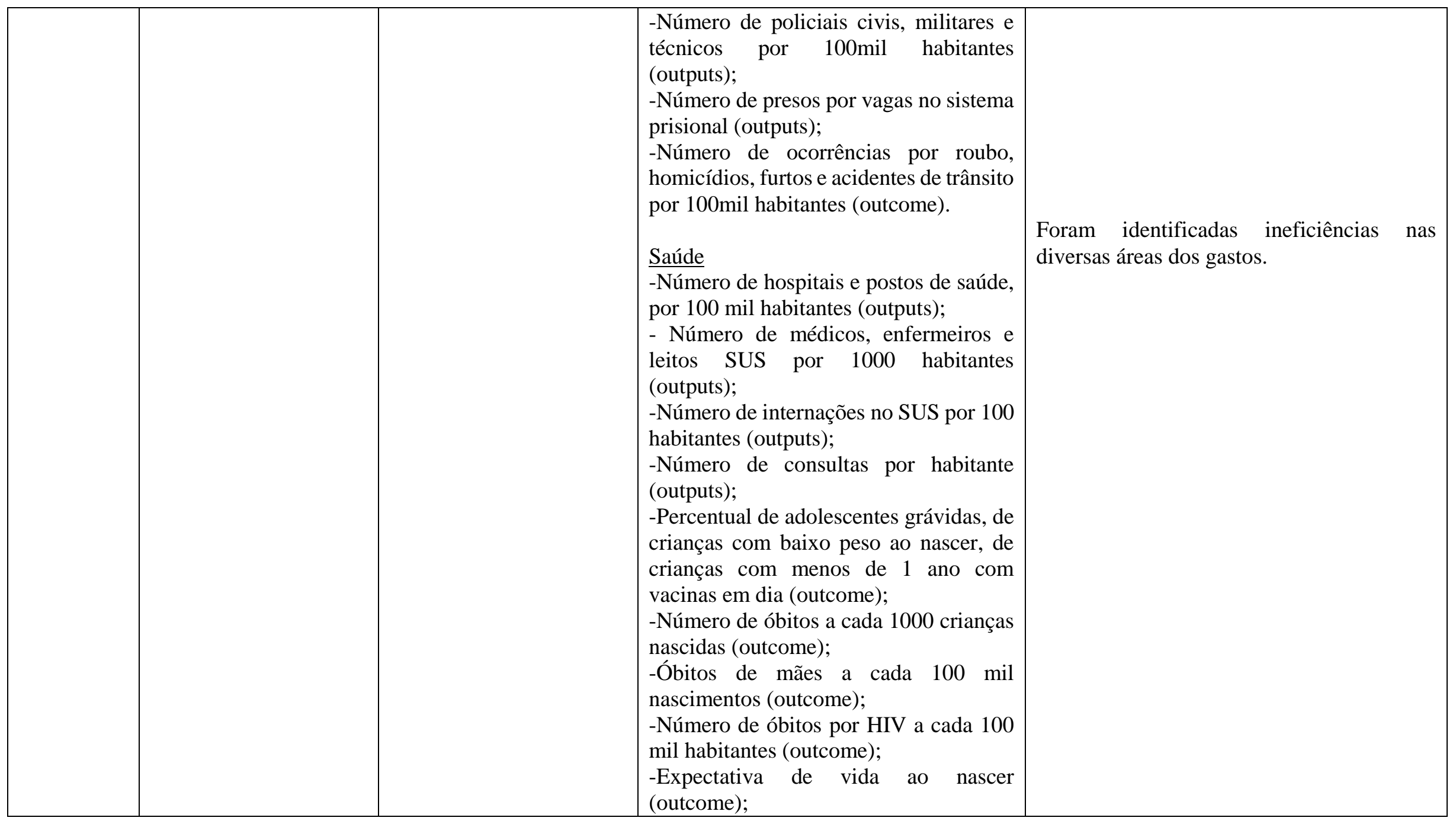




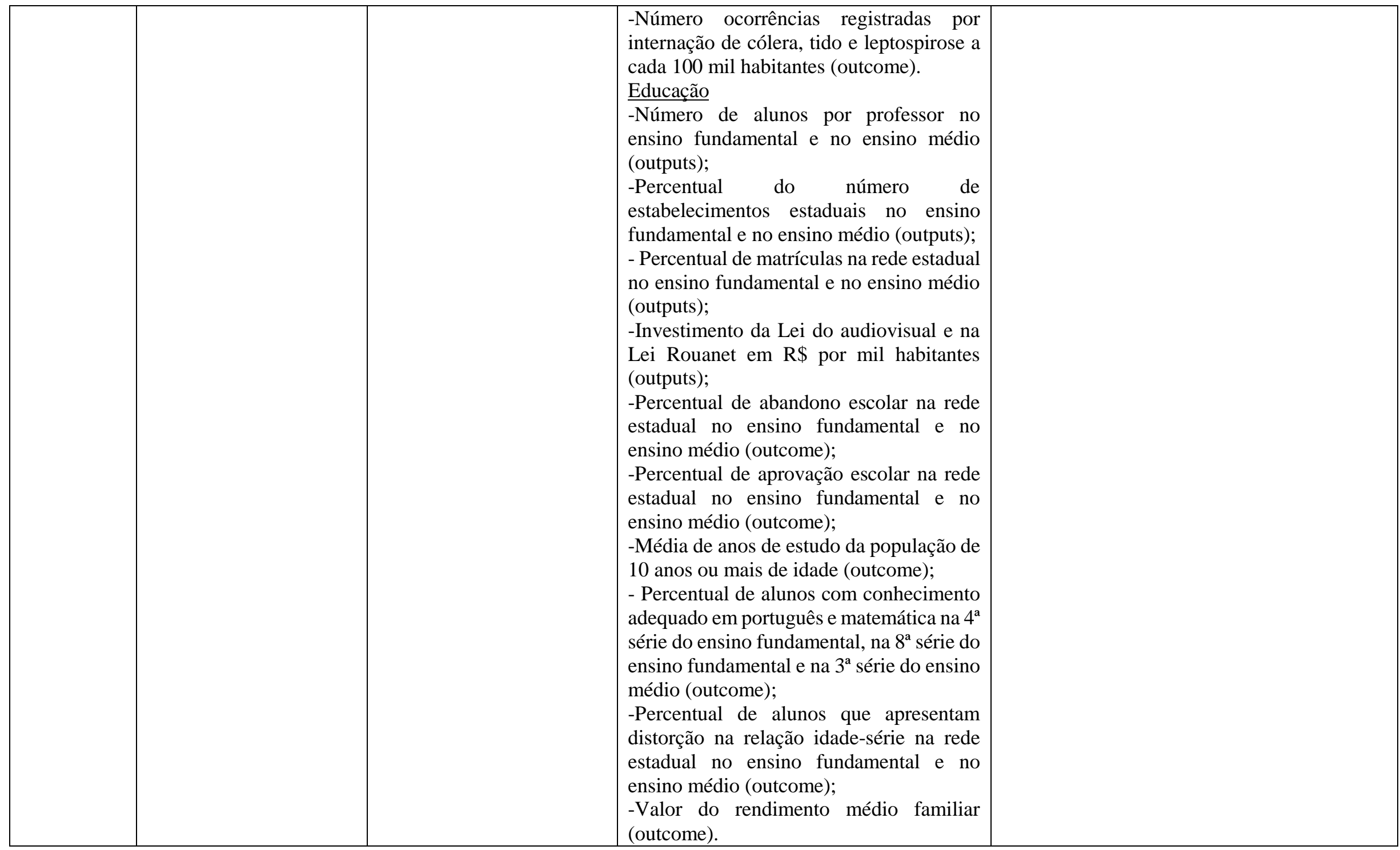




\begin{tabular}{|c|c|c|c|c|}
\hline Autor (es) & Método de análise & Objeto de Estudo & $\begin{array}{c}\text { Insumos (Inputs) e Produtos } \\
\text { (outputs) }\end{array}$ & Conclusões \\
\hline $\begin{array}{l}\text { Mandl, } \\
\text { Dierx e } \\
\text { Ilzkovitz } \\
\text { (2008) }\end{array}$ & DEA & $\begin{array}{l}\text { Avaliação da eficiência } \\
\text { na educação em } 19 \\
\text { países da OCDE } \\
\text { considerando dados de } \\
2007\end{array}$ & $\begin{array}{l}\text { - Gasto acumulado na educação/ PIB } \\
\text { (in); } \\
\text {-Teste de PISA (out); } \\
\text {-Taxa de ingresso nas faculdades } \\
\text { (out); } \\
\text {-Taxa de repetência (out). }\end{array}$ & $\begin{array}{l}\text { As despesas de educação em alguns países } \\
\text { são utilizadas de forma ineficiente. Foram } \\
\text { apresentadas para cada país na amostra } \\
\text { reformas na educação que possam } \\
\text { justificar a diferença de desempenho. }\end{array}$ \\
\hline $\begin{array}{l}\text { Schwellnus } \\
\text { (2009) }\end{array}$ & DEA & $\begin{array}{l}\text { Avalia a eficiência da } \\
\text { saúde e da educação no } \\
\text { México comparando } \\
\text { com outros países da } \\
\text { OCDE considerando } \\
\text { dados de } 2006\end{array}$ & $\begin{array}{l}\text { Educação: } \\
\text { - Gasto acumulado por aluno do } \\
\text { ensino médio (in); } \\
\text { - Teste de PISA (out). } \\
\text { Saúde: } \\
\text { - Leitos hospitalares (in); } \\
\text { - Médicos (in); } \\
\text { - Índice enfermeiros/médicos (in); } \\
\text { - Consumo de vegetais (in); } \\
\text { - Gastos totais em saúde (in); } \\
\text { - Expectativa de vida (out); } \\
\text { - Taxa de mortalidade (out). }\end{array}$ & $\begin{array}{l}\text { Foram realizadas diversas recomendações } \\
\text { específicas para o México que tendem a } \\
\text { aumentar a eficiência na educação e na } \\
\text { saúde. }\end{array}$ \\
\hline $\begin{array}{l}\text { Wang e } \\
\text { Alvi } \\
(2011)\end{array}$ & $\begin{array}{l}\text { DEA e Extreme } \\
\text { Bounds Analysis - } \\
\text { EBA associada com a } \\
\text { regressão tobit }\end{array}$ & $\begin{array}{l}\text { Avalia a eficiência do } \\
\text { governo no PIB em } 10 \\
\text { países da OCDE e } 7 \\
\text { países asiáticos } \\
\text { considerando dados } \\
\text { entre } 1986 \text { e } 2007\end{array}$ & $\begin{array}{l}\text {-Gastos do Governo (in) } \\
\text {-Variação do PIB (out) }\end{array}$ & $\begin{array}{l}\text { O aumento da participação das atividades } \\
\text { privadas na economia auxilia na redução } \\
\text { da ineficiência dos gastos públicos. }\end{array}$ \\
\hline
\end{tabular}




\begin{tabular}{|c|c|c|c|c|}
\hline Autor (es) & Método de análise & Objeto de Estudo & $\begin{array}{c}\text { Insumos (Inputs) e Produtos } \\
\text { (outputs) }\end{array}$ & Conclusões \\
\hline $\begin{array}{l}\text { Grigoli } \\
\text { (2014) }\end{array}$ & DEA e SFA & $\begin{array}{l}\text { Avaliação da eficiência } \\
\text { na educação em } 89 \\
\text { economias emergentes } \\
\text { considerando dados entre } \\
2000 \text { e } 2009 .\end{array}$ & $\begin{array}{l}\text {-Despesas públicas por aluno no ensino } \\
\text { secundário (in); } \\
\text {-Taxa de matrícula no ensino médio } \\
\text { (out). }\end{array}$ & $\begin{array}{l}\text { Foram encontradas evidências de que as } \\
\text { despesas de educação secundária são } \\
\text { ineficientes em muitas economias } \\
\text { emergentes e em desenvolvimento, } \\
\text { especialmente na África. Os resultados } \\
\text { sugerem que em níveis de gastos correntes, } \\
\text { economias do grupo de renda mais baixa } \\
\text { poderia melhorar sua taxa de escolarização } \\
\text { líquida, em média, por } 36 \text { pontos } \\
\text { percentuais, face a } 7 \text { pontos percentuais em } \\
\text { economias de renda mais elevada. }\end{array}$ \\
\hline $\begin{array}{c}\text { Lima, } \\
\text { Moreira e } \\
\text { Souza } \\
(2013)\end{array}$ & Fronteira Estocástica & $\begin{array}{l}\text { Avaliação dos } 26 \text { Estados } \\
\text { de } 2004 \text { a } 2009\end{array}$ & $\begin{array}{l}\text {-PIB per Capita (in); } \\
\text {-Coeficiente de Gini ajustado (in); } \\
\text {-Valor dos benefícios do programa; } \\
\text {-Bolsa Família per capita (in); } \\
\text {-Taxa de desocupação ajustada (in); } \\
\text {-Taxa de não pobres (out). }\end{array}$ & $\begin{array}{l}\text { O coeficiente estimado da transferência de } \\
\text { renda per capita para a população pobre } \\
\text { apresenta um coeficiente positivo indicando } \\
\text { que os gastos com bolsa família são } \\
\text { ineficientes no combate à pobreza. }\end{array}$ \\
\hline $\begin{array}{l}\text { Costa et alli } \\
\text { (2015) }\end{array}$ & $\begin{array}{l}\text { DEA, Painel Efeitos } \\
\text { Fixos e Regressão } \\
\text { Quantílica }\end{array}$ & $\begin{array}{c}\text { Avaliação de } 831 \\
\text { municípios do Estado de } \\
\text { Minas Gerais entre } 2006 \\
\text { e } 2009\end{array}$ & $\begin{array}{l}\text { Saúde: } \\
\text { - Gasto per capita com atividades de } \\
\text { saúde (in) } \\
\text { - Valor adicionado fiscal per capita (in) } \\
\text { - Proporção da População atendida pelo } \\
\text { Programa Saúde da Família (PSF) (out) } \\
\text { - Proporção de nascidos vivos cujas } \\
\text { mães realizaram sete consultas de pré- } \\
\text { natal ou mais (out) }\end{array}$ & $\begin{array}{l}\text { A partir dos escores dos indicadores das } \\
\text { dimensões saúde, educação e emprego e } \\
\text { renda foi criado o indicador denominado: } \\
\text { Índice de Eficiência Municipal indica a } \\
\text { eficiência no município na promoção do } \\
\text { desenvolvimento socioeconômico. Os } \\
\text { municípios com melhores condições } \\
\text { socioeconômicas, obtiveram, para todos os } \\
\text { anos, melhor nível de eficiência que os } \\
\text { demais. }\end{array}$ \\
\hline
\end{tabular}




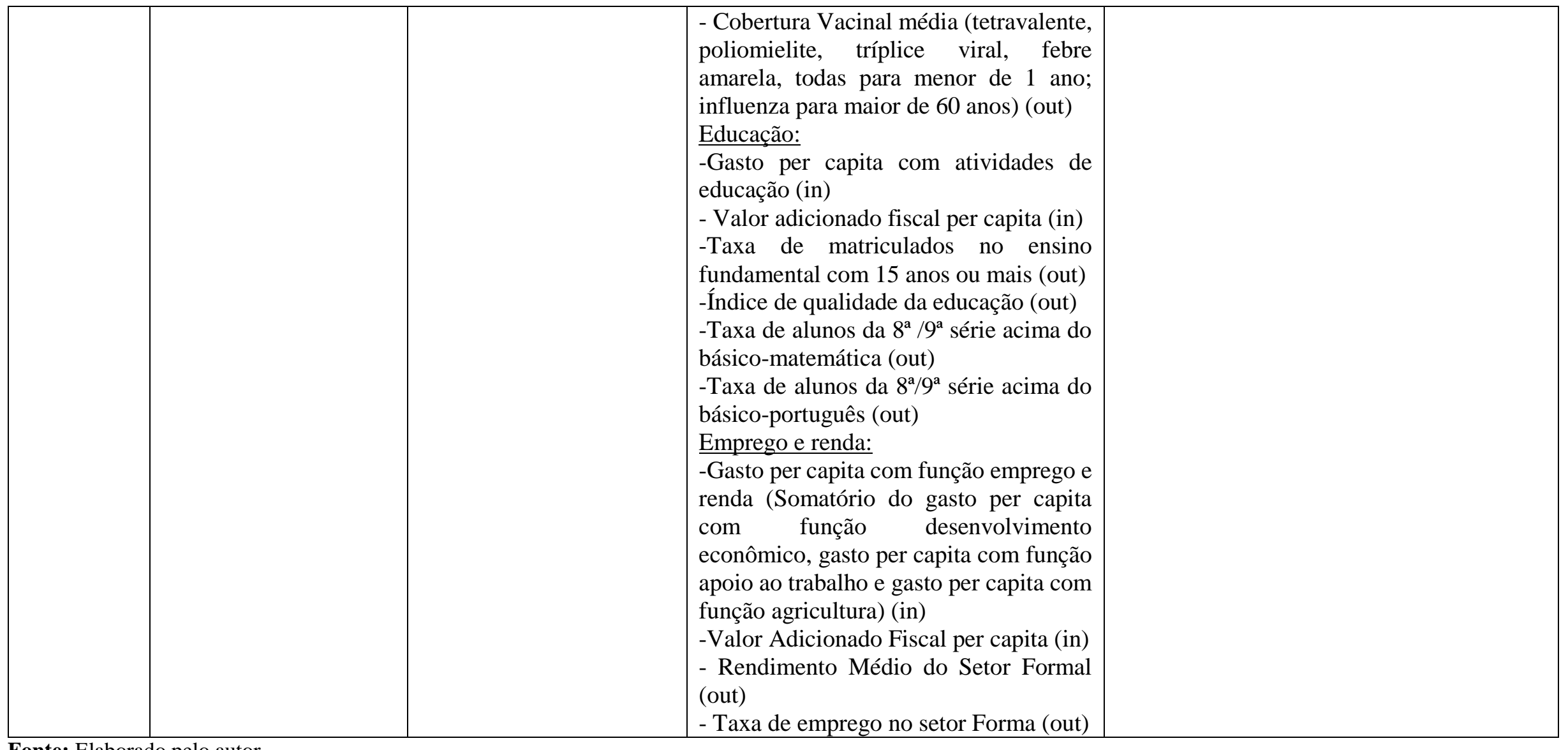

Fonte: Elaborado pelo autor

- Cobertura Vacinal média (tetravalente, Educação:

Gasto per capita com atividades de educação (in)

básico-português (out)

Emprego e renda:

cona funão agricultura) (in)

(out)
- Taxa de emprego no setor Forma (out) 


\subsection{Breve retrato das desigualdades no Brasil}

Neste tópico serão apresentadas as séries históricas dos principais dados relacionados à geração de riqueza nos Estados e os principais indicadores relacionados à desigualdade de renda mencionados na seção 2.1 e que estão disponíveis nos bancos de dados oficiais. Considerando o objeto do estudo, a comparação será realizada considerando-se as cinco regiões administrativas: Norte, Nordeste, Centro-Oeste, Sudeste e Sul. Inicialmente, a Tabela 1 apresenta a participação do PIB por região.

Tabela 1 - Participação das regiões brasileiras no PIB nacional

\begin{tabular}{ccccccc}
\hline Ano & Norte & Nordeste & Sudeste & Sul & Centro-Oeste & $\begin{array}{c}\text { Valor Total (R bilhões em } \\
\text { valores nominais) }\end{array}$ \\
\hline 1950 & $1,71 \%$ & $14,47 \%$ & $66,0 \%$ & $16,1 \%$ & $1,72 \%$ & $*$ \\
1960 & $2,30 \%$ & $14,53 \%$ & $63,59 \%$ & $17,26 \%$ & $2,32 \%$ & $*$ \\
1970 & $2,22 \%$ & $11,92 \%$ & $65,21 \%$ & $17,29 \%$ & $3,61 \%$ & $*$ \\
1980 & $3,33 \%$ & $12,17 \%$ & $62,19 \%$ & $17,11 \%$ & $5,02 \%$ & $*$ \\
1985 & $4,22 \%$ & $13,83 \%$ & $59,45 \%$ & $15,96 \%$ & $5,39 \%$ & $*$ \\
1990 & $5,02 \%$ & $14,06 \%$ & $58,38 \%$ & $17,35 \%$ & $6,58 \%$ & 705 \\
1995 & $4,86 \%$ & $13,65 \%$ & $57,25 \%$ & $17,7 \%$ & $6,89 \%$ & 1.179 \\
2000 & $4,4 \%$ & $12,4 \%$ & $58,3 \%$ & $16,5 \%$ & $8,4 \%$ & 2.147 \\
2005 & $4,96 \%$ & $13,07 \%$ & $56,53 \%$ & $16,59 \%$ & $8,86 \%$ & 3.770 \\
2010 & $5,34 \%$ & $13,46 \%$ & $55,39 \%$ & $16,51 \%$ & $9,3 \%$ & 4.392 \\
2012 & $5,27 \%$ & $13,56 \%$ & $55,19 \%$ & $16,18 \%$ & $9,8 \%$ & $*$ \\
\hline
\end{tabular}

Fonte: IBGE ${ }^{10}$ (2016) IPEADATA (2016)

Legenda: * não foi considerado devido às alterações de moeda.

Observa-se que em 1950 em torno de $82 \%$ (oitenta e dois por cento) da riqueza estava concentrada nas regiões Sudeste e Sul; enquanto em 2010, esse valor caiu para $72 \%$ (setenta e dois por cento). Assim, em 60 (sessenta) anos houve uma redistribuição da geração de riqueza de apenas $10 \%$ (dez por cento). Um fator importante é que em termos absolutos o PIB da região Nordeste saltou de $\mathrm{R} \$ 84$ bilhões, em 1995, para R\$ 508 bilhões, em 2010; um aumento de 600\%. Na região Sudeste, o PIB saltou de R 417 bilhões, em 1995, para R 2.088 bilhões, em 2010; um aumento de 500\%. Assim, há que se reconhecer que houve um aumento incremental na geração de riqueza em todas as regiões ainda que continue existindo a concentração na região Sudeste.

\footnotetext{
${ }^{10}$ Os valores do PIB dos Estados para os anos de 2010, 2011 e 2012 divulgados pelo IBGE no quadriênio 2010-2013 estão divergentes dos valores do IPEA. Os valores de 2014 estarão disponíveis apenas em novembro de 2016, conforme mensagem a seguir formulada pelo e-SIC (pedido de informação deste autor $\mathrm{n}^{\mathrm{o}} 00089000004201631$ ): "Informamos que não dispomos dos dados das Contas Regionais do Brasil para 2014. A previsão de divulgação é para novembro de 2016".
} 
A seguir é a apresentada a Tabela 2 que contém os dados populacionais.

Tabela 2 - População das regiões brasileiras

\begin{tabular}{ccccccc}
\hline Ano & Norte & Nordeste & Sudeste & Sul & Centro-Oeste & População total (milhões) \\
\hline 1950 & $3,94 \%$ & $34,6 \%$ & $43,41 \%$ & $15,09 \%$ & $2,95 \%$ & 51,9 \\
1960 & $4,13 \%$ & $31,51 \%$ & $43,87 \%$ & $16,75 \%$ & $3,74 \%$ & 70,3 \\
1970 & $4,43 \%$ & $30,18 \%$ & $42,79 \%$ & $17,71 \%$ & $4,89 \%$ & 93,1 \\
1980 & $5,56 \%$ & $29,25 \%$ & $43,47 \%$ & $15,99 \%$ & $5,72 \%$ & 119 \\
1985 & $6,21 \%$ & $29,10 \%$ & $43,10 \%$ & $15,53 \%$ & $6,07 \%$ & 131,64 \\
1990 & $6,73 \%$ & $28,97 \%$ & $42,79 \%$ & $15,15 \%$ & $6,36 \%$ & 144,09 \\
1995 & $7,16 \%$ & $28,86 \%$ & $42,54 \%$ & $14,97 \%$ & $6,59 \%$ & 155,82 \\
2000 & $7,60 \%$ & $28,12 \%$ & $42,65 \%$ & $14,79 \%$ & $6,85 \%$ & 169,8 \\
2005 & $7,98 \%$ & $27,70 \%$ & $42,61 \%$ & $14,64 \%$ & $7,07 \%$ & 184,18 \\
2010 & $8,32 \%$ & $27,83 \%$ & $42,13 \%$ & $14,36 \%$ & $7,37 \%$ & 190,8 \\
2012 & $8,43 \%$ & $27,79 \%$ & $42,05 \%$ & $14,30 \%$ & $7,44 \%$ & 193,98 \\
\hline
\end{tabular}

Fonte: DATASUS (2016) e IPEADATA (2016)

Ao se comparar a proporção distribuição da população da Tabela 2 com a proporção da riqueza gerada da Tabela 1, observa-se que uma das regiões mais desfavorecidas da distribuição da riqueza pelo critério populacional foi a região Nordeste.

A seguir as Tabelas 3 e 4 mostram o percentual da população abaixo da linha da pobreza, e linha de extrema pobreza, respectivamente.

Tabela 3 - Percentual de pessoas na população total com renda domiciliar per capita inferior à linha de pobreza baseada em necessidades calóricas

\begin{tabular}{ccccccc}
\hline Ano & Norte & Nordeste & Sudeste & Sul & Centro-Oeste & População total (milhões) \\
\hline 1979 & 40,82 & 68,49 & 21,76 & 37,76 & 24,67 & $119,01^{\text {a }}$ \\
1985 & 37,00 & 69,36 & 28,41 & 34,17 & 33,08 & 131,64 \\
1990 & 37,86 & 69,28 & 27,59 & 35,94 & 31,19 & 144,09 \\
1995 & 44,01 & 61,28 & 21,04 & 26,60 & 26,99 & 155,8 \\
1999 & 46,90 & 60,55 & 21,60 & 26,93 & 26,20 & 163,9 \\
2005 & 43,16 & 53,63 & 19,07 & 18,81 & 20,56 & 184,2 \\
2009 & 32,95 & 39,61 & 11,83 & 11,56 & 11,59 & 191,47 \\
2012 & 27,46 & 30,81 & 8,01 & 7,50 & 6,74 & 194,97
\end{tabular}

Fonte: DATASUS (2016) e IPEADATA (2016)

Legenda: ${ }^{a}$ considerou-se a população de 1980 
Tabela 4 - Percentual de pessoas na população total com renda domiciliar per capita inferior à linha de extrema pobreza baseada em necessidades calóricas

\begin{tabular}{ccccccc}
\hline Ano & Norte & Nordeste & Sudeste & Sul & Centro-Oeste & População total (milhões) \\
\hline 1979 & 13,97 & 34,97 & 5,22 & 13,62 & 5,54 & $119,01^{\text {a }}$ \\
1985 & 11,90 & 38,42 & 8,83 & 11,37 & 9,97 & 131,64 \\
1990 & 14,78 & 41,63 & 9,30 & 13,97 & 10,79 & 144,09 \\
1995 & 18,46 & 31,61 & 6,87 & 9,82 & 8,92 & 155,8 \\
1999 & 19,87 & 30,97 & 6,89 & 9,80 & 8,26 & 163,9 \\
2005 & 14,95 & 24,23 & 5,31 & 5,59 & 5,74 & 184,2 \\
2009 & 10,00 & 15,51 & 3,21 & 3,13 & 3,39 & 191,47 \\
2012 & 8,25 & 11,07 & 2,43 & 2,16 & 1,98 & 194,97
\end{tabular}

Fonte: DATASUS (2016) e IPEADATA (2016)

Legenda: ${ }^{a}$ considerou-se a população de 1980.

Observa-se nas Tabelas 3 e 4 que as regiões com pior desempenho foram as regiões Norte e Nordeste. A seguir, as Tabelas 5 e 6 apresentam os dados de dois índices de desigualdades, respectivamente: Coeficiente de Gini e Coeficiente de Theil-T.

Tabela 5 - Evolução do Coeficiente de Gini nas regiões do Brasil

\begin{tabular}{cccccc}
\hline Ano & Norte & Nordeste & Sudeste & Sul & Centro-Oeste \\
\hline 1979 & 0.530 & 0.557 & 0.557 & 0.564 & 0.561 \\
1985 & 0.549 & 0.595 & 0.567 & 0.561 & 0.587 \\
1990 & 0.583 & 0.626 & 0.577 & 0.577 & 0.611 \\
1995 & 0.584 & 0.604 & 0.567 & 0.565 & 0.585 \\
1999 & 0.565 & 0.605 & 0.559 & 0.562 & 0.593 \\
2005 & 0.530 & 0.571 & 0.543 & 0.515 & 0.577 \\
2009 & 0.522 & 0.558 & 0.511 & 0.491 & 0.560 \\
2012 & 0.513 & 0.542 & 0.505 & 0.468 & 0.531 \\
\hline
\end{tabular}

Fonte: IPEADATA (2016)

Tabela 6 - Evolução do Coeficiente de Theil-T nas regiões do Brasil

\begin{tabular}{cccccc}
\hline Ano & Norte & Nordeste & Sudeste & Sul & Centro-Oeste \\
\hline 1979 & 0.557 & 0.691 & 0.622 & 0.665 & 0.617 \\
1985 & 0.622 & 0.807 & 0.638 & 0.644 & 0.708 \\
1990 & 0.722 & 0.881 & 0.676 & 0.660 & 0.777 \\
1995 & 0.713 & 0.810 & 0.645 & 0.645 & 0.689 \\
1999 & 0.639 & 0.801 & 0.620 & 0.627 & 0.736 \\
2005 & 0.577 & 0.705 & 0.594 & 0.523 & 0.712 \\
2009 & 0.554 & 0.666 & 0.527 & 0.479 & 0.664 \\
2012 & 0.529 & 0.676 & 0.551 & 0.450 & 0.599 \\
\hline
\end{tabular}

Fonte: IPEADATA (2016) 
Considerando que em ambos os indicadores quanto mais próximo de 1, maior a desigualdade, observa-se que as duas regiões mais desiguais foram as regiões Nordeste e Centro-Oeste. Por fim, as Tabelas 7 e 8 apresentam a proporção entre os mais ricos e os mais pobres. Ambas as Tabelas apresentam a medida do grau de desigualdade existente na distribuição de indivíduos segundo a renda domiciliar per capita. Ambas as séries são calculadas a partir das respostas à Pesquisa Nacional por Amostra de Domicílios (Pnad/IBGE).

Tabela 7 - Evolução da proporção da renda média entre os $10 \%$ mais ricos e os $40 \%$ mais pobres

\begin{tabular}{cccccc}
\hline Ano & Norte & Nordeste & Sudeste & Sul & Centro-Oeste \\
\hline 1979 & 14.98 & 17.18 & 17.93 & 18.34 & 17.82 \\
1985 & 16.72 & 21.38 & 19.22 & 18.14 & 21.07 \\
1990 & 20.76 & 26.21 & 20.49 & 20.45 & 25.01 \\
1995 & 20.73 & 23.11 & 19.14 & 18.64 & 20.97 \\
1999 & 18.58 & 23.24 & 18.04 & 18.53 & 21.78 \\
2005 & 15.10 & 19.10 & 16.41 & 14.08 & 19.63 \\
2009 & 14.61 & 17.94 & 13.59 & 12.21 & 17.67 \\
2012 & 13.98 & 16.31 & 13.10 & 10.68 & 15.03 \\
\hline
\end{tabular}

Fonte: IPEADATA (2016)

A Tabela 7 compara a renda média dos indivíduos pertencentes ao décimo mais rico da distribuição com a renda média dos indivíduos pertencentes aos quatro décimos mais pobres da mesma distribuição

Tabela 8 - Evolução da proporção da renda média entre os $20 \%$ mais ricos e os $20 \%$ mais pobres

\begin{tabular}{cccccc}
\hline Ano & Norte & Nordeste & Sudeste & Sul & Centro-Oeste \\
\hline 1979 & 14.95 & 16.39 & 19.11 & 19.16 & 17.74 \\
1985 & 16.67 & 20.68 & 20.96 & 19.05 & 21.24 \\
1990 & 21.64 & 26.37 & 23.18 & 23.01 & 26.67 \\
1995 & 21.91 & 24.25 & 21.68 & 21.14 & 22.69 \\
1999 & 20.52 & 23.87 & 20.34 & 21.09 & 22.73 \\
2005 & 15.44 & 20.16 & 17.55 & 15.49 & 20.21 \\
2009 & 15.51 & 19.76 & 14.73 & 13.48 & 17.95 \\
2012 & 15.31 & 17.93 & 13.85 & 11.63 & 15.39 \\
\hline
\end{tabular}

Fonte: IPEADATA (2016)

A Tabela 8 compara a renda média dos indivíduos pertencentes aos dois décimos mais ricos da distribuição com a renda média dos indivíduos pertencentes aos dois décimos mais pobres da mesma distribuição. Em ambas as tabelas as Regiões com pior desempenho foram as regiões Nordeste e Norte. 
Em que pese, os dados da Tabelas 1 a 8 terem dado ênfase ao aspecto interregional, o estudo terá como ênfase no aspecto intraregional na medida em que a unidade de observação são os estados da federação brasileira e não as cinco regiões administrativas.

\section{METODOLOGIA DA ANÁLISE EMPÍRICA}

Nesta seção serão apresentadas as técnicas de análise quantitativa de dados, bem como serão detalhados os modelos funcionais, os modelos econométricos e as respectivas variáveis que servirão como proxies para se testar as hipóteses de pesquisa enunciadas preliminarmente nas seções 2.4 e 2.6 .

\subsection{Procedimentos metodológicos}

Para a consecução do objetivo proposto de avaliar de que forma as funções orçamentárias alocativa e distributiva impactam a desigualdade de renda dos Estados do Brasil entre 1995 e 2012, foram utilizadas variáveis como receitas, despesas, indicadores de desigualdade de renda, insumos utilizados, produtos ofertados e resultados alcançados no âmbito do setor público. Este estudo adotou a tipologia empírica, com abordagem quantitativa.

\subsubsection{Sistema de Hipóteses}

A fim de propiciar uma avaliação lógica e consistente dos resultados a serem alcançados, foram elaboradas as Figuras 4 e 5 contendo as hipóteses da pesquisa 1 a 6 .

Na Figura 4, observa-se que serão testadas inicialmente as três hipóteses de pesquisa enunciadas na seção 2.4: Hipótese 1 - Os estados com maior proporção de despesas nas áreas de educação e saúde reduziram a desigualdade de renda, coeteris paribus; Hipótese $\mathbf{2}$ - Os estados com maior proporção de impostos progressivos reduziram a desigualdade de renda, coeteris paribus; Hipótese 3 - Os estados com maior proporção de transferências de renda direta reduziram a desigualdade de renda, coeteris paribus. Em todas as hipóteses foram selecionadas como variáveis dependentes de desigualdade os seguintes índices: Gini, Theil-T, proporção entre os $10 \%$ mais ricos e os $40 \%$ mais pobres, proporção entre os $20 \%$ mais ricos e os $20 \%$ mais pobres. Dessa forma, as hipóteses 1, 2 e 3 da pesquisa serão testadas quatro vezes distintas cada uma. Considerando a natureza dos indicadores, além do uso da regressão de dados em painel pelos Mínimos Quadrados Ordinários (MQO) será utilizada a regressão painel tobit.

Quanto às variáveis independentes, essas considerarão as peculiaridades de cada fenômeno a ser medido. No caso da hipótese 1, relacionada à função alocativa, foram selecionadas as despesas relacionadas aos bens meritórios: saúde e educação. 
Figura 4 - Sistema Básico de Hipóteses - Fase 1

Sistema de Hipóteses - Painel e Painel Tobit

\begin{tabular}{|c|c|c|}
\hline Hipóteses & Variáveis Dependentes & Variáveis Independentes \\
\hline $\begin{array}{l}\text { H1: os estados com maior proporção de } \\
\text { despesas nas áreas de educação e saúde } \\
\text { reduziram a desigualdade de renda, coeteris } \\
\text { paribus. }\end{array}$ & & Despesas meritórias: \\
\hline $\begin{array}{l}\text { H2: Os estados com maior proporção de } \\
\text { impostos progressivos reduziram a desigualdade- } \\
\text { de renda, coeteris paribus. }\end{array}$ & $\begin{array}{c}\text { 1. Coeficiente de Gini. } \\
\text { 2. Coeficiente de Theil. } \\
\text { 3. Relação entre } 10 \% \text { mais ricos e } 40 \% \text { mais } \\
\text { pobres. } \\
\text { 4. Relação entre } 20 \% \text { mais ricos e } 20 \% \text { mais } \\
\text { pobres. }\end{array}$ & \begin{tabular}{|l}
\multicolumn{1}{|c|}{ Tributos Progressivos: } \\
-Imposto de Renda \\
-Imposto Territorial Rural \\
-Imposto sobre Veículos Automotores \\
-Imposto sobre Transmissão Bens Intervivos \\
- Impostos sobre Transmissão Causa Mortis e Doações \\
- Imposto Predial Territorial Urbano
\end{tabular} \\
\hline $\begin{array}{l}\text { H3: Os entes com maior proporçãa de } \\
\text { transferências de renda direta reduziram a }\end{array}$ & & $\begin{array}{l}\text { Transferências de Renda Direta: } \\
\text {-Bolsa Família } \\
\text {-Benefício de Prestação Continuada ao Idoso } \\
\text {-Benefício de Prestação Continuada ao Deficiente }\end{array}$ \\
\hline
\end{tabular}

Fonte: Elaborado pelo autor 
Figura 5 - Sistema Básico de Hipóteses - Fase 2

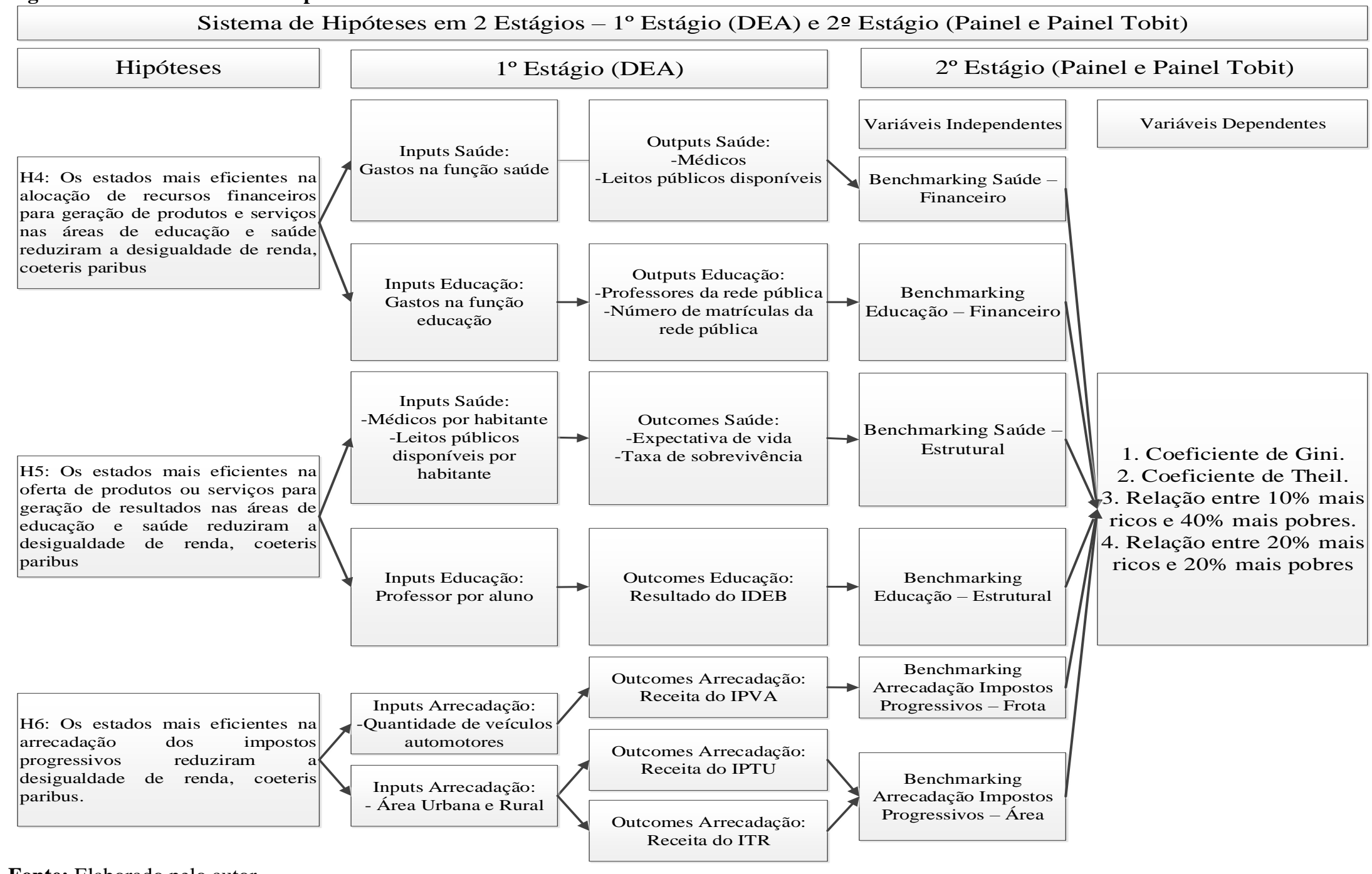

Fonte: Elaborado pelo autor 
No caso da hipótese 2, relacionada à função distributiva, foram selecionados os impostos progressivos arrecadados daquela região (no caso Estados), independente da competência para arrecadar (seja da União, dos Estados ou dos Municípios).

No caso da hipótese 3, relacionada à função distributiva, foram selecionadas as transferências de renda diretamente concedidas pela União à população do Estado.

Na Figura 5 observa-se que serão testadas as três hipóteses de pesquisa enunciadas na seção 2.6: Hipótese 4 - Os estados mais eficientes na alocação de recursos financeiros para geração de produtos e serviços nas áreas de educação e saúde reduziram a desigualdade de renda, coeteris paribus; Hipótese 5 - Os estados mais eficientes na oferta de produtos ou serviços para geração de resultados nas áreas de educação e saúde reduziram a desigualdade de renda, coeteris paribus.; Hipótese 6 - Os estados mais eficientes na arrecadação dos impostos progressivos reduziram a desigualdade de renda, coeteris paribus. Essas hipóteses de pesquisa tratam da eficiência no setor público, sendo que as hipóteses 4 e 5 estão relacionadas à hipótese 1 e se relacionam com a função alocativa, enquanto a hipótese 6 está relacionada a hipótese 2 e se relaciona com a função distributiva. Não foi possível estabelecer hipótese de eficiência que considerasse as transferências de renda diretas - hipótese 3.

A fim de se alcançar o objetivo proposto nas hipóteses 4 a 6 , foi aplicado um modelo em dois estágios. No primeiro estágio se obteve, a partir da Análise Envoltória de Dados, o índice de eficiência dos 26 estados mais o Distrito Federal enquanto territórios, perfazendo assim 27 unidades de observação por ano. Esse índice de eficiência denominado benchmarking será utilizado em um segundo estágio como variável independente. Neste segundo estágio, as hipóteses 4, 5 e 6 serão testadas quatro vezes considerando as variáveis dependentes definidas: Gini, Theil-T, proporção entre os $10 \%$ mais ricos e os $40 \%$ mais pobres, proporção entre os $20 \%$ mais ricos e os $20 \%$ mais pobres. 


\subsubsection{Plano Amostral}

A população, neste estudo, é formada pelo conjunto de Estados brasileiros. As informações necessárias à pesquisa foram obtidas especialmente nos seguintes bancos de dados: Secretaria do Tesouro Nacional - $\mathrm{STN}^{11}$, Datasus ${ }^{12}$, Ipeadata ${ }^{13}$, Agência Nacional do Petróleo - ANP ${ }^{14}$, Agência Nacional de Energia Elétrica - ANEEL ${ }^{15}$, compreendendo o período de 1995 a 2012, perfazendo assim 18 períodos de medição dos 26 estados da federação e o Distrito Federal. A tabelas a seguir contêm o detalhamento das variáveis e as respectivas limitações das bases de dados que refletem na tese.

Tabela 9 - Variáveis, fontes de dados e limitações da hipótese 1

\begin{tabular}{ccc}
\hline Variável & $\begin{array}{c}\text { Fonte do } \\
\text { Dado }\end{array}$ & Limitação \\
\hline PIB & IPEADATA & - \\
\hline $\begin{array}{c}\text { Coeficiente de Gini, Coeficiente de } \\
\text { Theil-T, Relação entre os 10\% mais } \\
\text { ricos e os 40\% mais pobres, Relação } \\
\text { entre os 20\% mais ricos e os 20\% mais } \\
\text { pobres }\end{array}$ & IPEADATA & Para dados ausentes referentes aos anos de \\
& 2010 e 2000 foi utilizada interpolação \\
exponencial.
\end{tabular}
Fonte: Elaborado pelo autor

\footnotetext{
${ }^{11} \mathrm{https}: / /$ www.tesouro.fazenda.gov.br/pt/contas-anuais.

${ }^{12} \mathrm{http}: / / \mathrm{www} 2$. datasus.gov.br/DATASUS/index.php?area=02.

${ }^{13} \mathrm{http} / / / \mathrm{www}$. ipeadata.gov.br/

14 Os foram fornecidos pelo sistema E-SIC: http://www.acessoainformacao.gov.br/sistema/site/index.html?ReturnUrl=\%2fsistema\%2f, protocolo 48700006560201500 de 31de agosto de 2015.

${ }^{15} \mathrm{http} / /$ www.aneel.gov.br/aplicacoes/cmpf/gerencial/

${ }^{16}$ No caso das despesas com saúde e educação considerou-se para cada unidade de observação a média: do somatório despesa com saúde entre 2004 e 2012 divido pelo somatório da despesa com saúde e saneamento entre 2004 e 2012. O resultado anterior foi a multiplicado ano a ano entre 1995 e 2003 pelo valor das despesas com saúde e saneamento
} 
Tabela 10 - Variáveis, fontes de dados e limitações da hipótese 2

\begin{tabular}{|c|c|c|}
\hline Variável & Fonte do Dado & Limitação \\
\hline PIB & IPEADATA & - \\
\hline $\begin{array}{l}\text { Coeficiente de Gini, Coeficiente de Theil-T, } \\
\text { Relação entre os } 10 \% \text { mais ricos e os } 40 \% \text { mais } \\
\text { pobres, Relação entre os } 20 \% \text { mais ricos e os } \\
20 \% \text { mais pobres }\end{array}$ & IPEADATA & $\begin{array}{l}\text { Para dados ausentes referentes aos } \\
\text { anos de } 2010 \text { e } 2000 \text { foi utilizada } \\
\text { interpolação exponencial. }\end{array}$ \\
\hline $\begin{array}{l}\text { Imposto de Renda - IR e Imposto Territorial } \\
\text { Rural - ITR arrecadados pela União }\end{array}$ & $\begin{array}{l}\text { Secretaria de } \\
\text { Receita Federal } \\
\text { do Brasil }{ }^{17}\end{array}$ & $\begin{array}{c}\text { Os dados entre } 1995 \text { e } 1999 \\
\text { (inclusive) não são disponibilizados } \\
\text { pelo órgão }{ }^{18} \text {. Para tanto foi utilizado } \\
\text { um modelo de correção }{ }^{19} \text {. }\end{array}$ \\
\hline $\begin{array}{l}\text { Imposto de Renda - IR arrecadados pelos } \\
\text { Estados, Imposto sobre Propriedade de } \\
\text { Veículos Automotores - IPVA e o Imposto de } \\
\text { Transmissão Causa Mortis e Doações - ITCMD }\end{array}$ & STN & $\begin{array}{c}\text { Entre } 1995 \text { (inclusive) e } 2000 \\
\text { (inclusive) não se segregavam os } \\
\text { diversos impostos estaduais. Para } \\
\text { tanto foi utilizado um modelo de } \\
\text { correção } \\
\end{array}$ \\
\hline $\begin{array}{l}\text { Imposto de Renda - IR arrecadados pelos } \\
\text { Municípios, Imposto Territorial Rural - ITR } \\
\text { arrecadados pelos Municípios, Imposto sobre } \\
\text { Propriedade Territorial Urbana - IPTU e o } \\
\text { Imposto de Transmissão Bens Intervivos - ITBI }\end{array}$ & STN & $\begin{array}{c}\text { Entre } 1995 \text { (inclusive) e } 1996 \\
\text { (inclusive) não se segregavam os } \\
\text { diversos impostos municipais. Para } \\
\text { tanto foi utilizado um modelo de } \\
\text { correção }^{21} \text {. }\end{array}$ \\
\hline Recursos de royalties do petróleo & ANP & Dados de 1995 e 1996 ausentes \\
\hline Recursos de royalties do setor elétrico & ANEEL & Dados de 1995 e 1996 ausentes \\
\hline
\end{tabular}

Fonte: Elaborado pelo autor

Tabela 11 - Variáveis, fontes de dados e limitações da hipótese 3

\begin{tabular}{|c|c|c|}
\hline Variável & Fonte do Dado & Limitação \\
\hline PIB & IPEADATA & - \\
\hline $\begin{array}{l}\text { Coeficiente de Gini, Coeficiente de Theil-T, } \\
\text { Relação entre os } 10 \% \text { mais ricos e os } 40 \% \text { mais } \\
\text { pobres, Relação entre os } 20 \% \text { mais ricos e os } \\
20 \% \text { mais pobres }\end{array}$ & IPEADATA & $\begin{array}{l}\text { Para dados ausentes referentes } \\
\text { aos anos de } 2010 \text { e } 2000 \text { foi } \\
\text { utilizada interpolação } \\
\text { exponencial. }\end{array}$ \\
\hline $\begin{array}{c}\text { Bolsa Família, Benefício de Prestação } \\
\text { Continuada ao idoso, Benefício de Prestação } \\
\text { Continuada ao deficiente }\end{array}$ & IPEADATA & $\begin{array}{l}\text { Bolsa Família possui dados a } \\
\text { contar de 2004, enquanto o BPC } \\
\text { possui dados a contar de } 1996 .\end{array}$ \\
\hline Recursos de royalties do petróleo & $\begin{array}{c}\text { Agência Nacional } \\
\text { do Petróleo }\end{array}$ & Dados de 1995 e 1996 ausentes \\
\hline Recursos de royalties do setor elétrico & $\begin{array}{l}\text { Agência Nacional } \\
\text { de Energia Elétrica }\end{array}$ & Dados de 1995 e 1996 ausentes \\
\hline
\end{tabular}

Fonte: Elaborado pelo autor

\footnotetext{
${ }^{17} \mathrm{http} / / /$ www.receita.fazenda.gov.br/Historico/Arrecadacao/PorEstado/default.htm

${ }^{18}$ Em resposta pelo sistema E-SIC:

http://www.acessoainformacao.gov.br/sistema/site/index.html?ReturnUrl=\%2fsistema\%2f, protocolo 16853006094201514 de 28 de setembro de 2015 foi informado que: A Receita Federal disponibiliza em seu sítio na internet os valores de arrecadação disponíveis a partir do ano de 2000, ano a partir do qual os atuais extratores de dados conseguem gerar os dados. Para anos anteriores, os atuais extratores não captam os dados solicitados, sendo que deverá haver, para a solicitação feita, extração via apuração especial. Ocorre que tal tipo de extração exigiria alocação de recursos para a realização de um estudo adicional e específico para atender tal demanda, com geração de custos adicionais para o órgão.

${ }^{19}$ A fim de se obter os dados de 1995 a 1999 foi utilizada uma função exponencial da soma das funções (i) interceptação do logaritmo neperiano do IR e (ii) e inclinação do logaritmo neperiado do IR. O mesmo procedimento foi repetido para o ITR.

${ }^{20}$ Considerou-se para cada unidade de observação a média do somatório receita tributária entre 2001 e 2012 divido pelo somatório do IPVA entre 2001 e 2012. O resultado anterior foi a multiplicado ano a ano entre 1995 e 2000 pelo valor do IPVA. O mesmo procedimento foi feito para o IR estadual e para o ITCMD.

${ }^{21}$ Considerou-se para cada unidade de observação a média do somatório receita tributária entre 1997 e 2012 divido pelo somatório do IPTU entre 1997 e 2012. O resultado anterior foi a multiplicado ano a ano entre 1995 e 1996 pelo valor do IPTU. O mesmo procedimento foi feito para o IR municipal e para o ITBI.
} 
Tabela 12 - Variáveis, fontes de dados e limitações da hipótese 4

\begin{tabular}{|c|c|c|c|}
\hline Fase & Variável & $\begin{array}{c}\text { Fonte do } \\
\text { Dado }\end{array}$ & Limitação \\
\hline \multirow{5}{*}{1} & $\begin{array}{c}\text { Despesas nas áreas de } \\
\text { educação e saúde nível } \\
\text { estadual: classificação por } \\
\text { função }\end{array}$ & $\begin{array}{c}\text { Secretaria do } \\
\text { Tesouro } \\
\text { Nacional }\end{array}$ & $\begin{array}{c}\text { Até } 2001 \text { as despesas com educação estavam } \\
\text { agregadas com cultura, e as despesas com } \\
\text { saúde estavam agregadas com saneamento. } \\
\text { Para tanto foi utilizado modelo de correção } \\
\text { explorado na Tabela } 9 .\end{array}$ \\
\hline & Médicos & Datasus $^{22}$ & $\begin{array}{c}\text { Os dados de } 2011^{23} \text { e } 2012^{24} \text { foram localizados } \\
\text { no site do CREMESP. Para os anos de } 2002 \text { e } \\
2000 \text { do Estado de Tocantins foi utilizada a } \\
\text { interpolação exponencial. }\end{array}$ \\
\hline & $\begin{array}{l}\text { Leitos do Sistema Único de } \\
\text { Saúde }\end{array}$ & Datasus $^{25}$ & $\begin{array}{l}\text { Em 2004, houve uma mudança da forma de } \\
\text { contabilização, não sendo disponibilizados os } \\
\text { dados. Assim, houve a necessidade de se fazer } \\
\text { a interpolação exponencial entre } 2003 \text { e } 2005 \text {. } \\
\text { Para 2005, foi considerada a situação de } \\
\text { dezembro/2005 e para os demais anos foi } \\
\text { considerada a média. }\end{array}$ \\
\hline & $\begin{array}{c}\text { Matrículas no ensino } \\
\text { público }\end{array}$ & INEP & $\begin{array}{l}\text { A fim de manter um alinhamento com os } \\
\text { dados disponíveis do IDEB com início a contar } \\
\text { de } 2005 \text {, os dados foram levantados } \\
\text { considerando as seguintes fases da formação } \\
\text { escolar: ensino fundamental anos iniciais } \\
\text { (incluindo antiga alfabetização), ensino } \\
\text { fundamental anos finais, e ensino médio. }\end{array}$ \\
\hline & $\begin{array}{c}\text { Professores no ensino } \\
\text { público }\end{array}$ & INEP & $\begin{array}{l}\text { A fim de manter um alinhamento com os } \\
\text { dados disponíveis do IDEB com início a contar } \\
\text { de } 2005 \text {, os dados foram levantados } \\
\text { considerando as seguintes fases da formação } \\
\text { escolar: ensino fundamental anos iniciais } \\
\text { (incluindo antiga alfabetização), ensino } \\
\text { fundamental anos finais, e ensino médio. }\end{array}$ \\
\hline
\end{tabular}

Coeficiente de Gini,

Coeficiente de Theil-T, Relação entre os $10 \%$ mais ricos e os $40 \%$ mais pobres, Relação entre os $20 \%$ mais ricos e os $20 \%$ mais pobres

$\begin{array}{ccc}\begin{array}{c}\text { Recursos de royalties do } \\ \text { petróleo }\end{array} & \text { ANP } & \text { Dados de } 1995 \text { e } 1996 \text { ausentes }\end{array}$

Recursos de royalties do setor elétrico

ANELL

Dados de 1995 e 1996 ausentes

IPEADATA $\quad 2010$ e 2000 foi utilizada interpolação exponencial.

Fonte: Elaborado pelo autor

\footnotetext{
${ }^{22}$ http://tabnet.datasus.gov.br/cgi/deftohtm.exe?idb2012/e01.def

${ }^{23} \mathrm{http} / / /$ www.cremesp.org.br/pdfs/demografia_2_dezembro.pdf

${ }^{24} \mathrm{http}: / /$ www.cremesp.org.br/pdfs/DemografiaMedicaBrasilVol2.pdf

${ }^{25} \mathrm{http}: / /$ tabnet.datasus.gov.br/cgi/idb2012/e03.htm
} 
Tabela 13 - Variáveis, fontes de dados e limitações da hipótese 5

\begin{tabular}{|c|c|c|c|}
\hline Fase & Variável & $\begin{array}{l}\text { Fonte do } \\
\text { Dado }\end{array}$ & Limitação \\
\hline \multirow{6}{*}{1} & Médicos por pessoa & $\begin{array}{c}\text { Datasus e } \\
\text { IPEADATA }\end{array}$ & $\begin{array}{l}\text { Os dados de } 2011^{26} \text { e } 2012^{27} \text { foram localizados no } \\
\text { site do CREMESP. }\end{array}$ \\
\hline & $\begin{array}{l}\text { Leitos do Sistema Único de } \\
\text { Saúde por pessoa }\end{array}$ & $\begin{array}{l}\text { Datasus e } \\
\text { IPEADATA }\end{array}$ & $\begin{array}{l}\text { Em 2004, houve uma mudança da forma de } \\
\text { contabilização, não sendo disponibilizados os } \\
\text { dados. Assim, houve a necessidade de se fazer a } \\
\text { interpolação exponencial entre } 2003 \text { e } 2005 \text {. Para } \\
\text { 2005, foi considerada a situação de dezembro/2005 } \\
\text { e para os demais anos foi considerada a média. }\end{array}$ \\
\hline & $\begin{array}{l}\text { Professores por alunos } \\
\text { matriculados }\end{array}$ & INEP & $\begin{array}{l}\text { A fim de manter um alinhamento com os dados } \\
\text { disponíveis do IDEB com início a contar de } 2005 \text {, } \\
\text { os dados foram levantados considerando as } \\
\text { seguintes fases da formação escolar: ensino } \\
\text { fundamental anos iniciais (incluindo antiga } \\
\text { alfabetização), ensino fundamental anos finais, e } \\
\text { ensino médio. }\end{array}$ \\
\hline & Taxa de mortalidade infantil & Datasus $^{28}$ & $\begin{array}{c}\text { No cálculo do indicador, foi utilizada a "taxa de } \\
\text { sobrevivência infantil }=1000 \text { - Taxa de mortalidade } \\
\text { infantil"). }\end{array}$ \\
\hline & Expectativa de Vida & Datasus $^{29}$ & - \\
\hline & $\begin{array}{l}\text { Índice de desenvolvimento } \\
\text { da Educação Básica }\end{array}$ & $\mathrm{INEP}^{30}$ & $\begin{array}{l}\text { A primeira medição ocorreu a partir de } 2005 \text {. A } \\
\text { medição vale por } 2 \text { anos. Assim, a medição do ano } \\
\text { ímpar foi apropriada ao ano par imediatamente } \\
\text { anterior. A pesquisa por Unidade da Federação } \\
\text { oferece os seguintes critérios de pesquisa: total } \\
\text { (escolas públicas urbanas e escolas privadas urbanas; } \\
\text { rede pública (escolas públicas urbanas), rede } \\
\text { estadual (escolas urbanas da rede estadual), rede } \\
\text { privada (escolas urbanas da rede privada). Porém, o } \\
\text { critério rede pública não retorna dados na consulta. } \\
\text { Assim, foi utilizada a consulta rede estadual. O IDEB } \\
\text { é calculado para o ensino fundamental } 5^{\circ} \text { ano, ensino } \\
\text { fundamental } 9^{\circ} \text { ano e ensino médio. }\end{array}$ \\
\hline
\end{tabular}

Coeficiente de Gini,

Coeficiente de Theil-T,

Relação entre os $10 \%$ mais ricos e os $40 \%$ mais pobres,

IPEADATA

Para dados ausentes referentes aos anos de 2010 e 2000 foi utilizada interpolação exponencial.

2 Relação entre os $20 \%$ mais ricos e os $20 \%$ mais pobres

\begin{tabular}{|c|c|c|}
\hline $\begin{array}{c}\text { Recursos de royalties do } \\
\text { petróleo }\end{array}$ & ANP & Dados de 1995 e 1996 ausentes \\
\hline
\end{tabular}

Recursos de royalties do setor elétrico

Fonte: Elaborado pelo autor

\footnotetext{
${ }^{26} \mathrm{http}: / /$ www.cremesp.org.br/pdfs/demografia_2_dezembro.pdf

${ }^{27} \mathrm{http}: / /$ www.cremesp.org.br/pdfs/DemografiaMedicaBrasilVol2.pdf

${ }^{28} \mathrm{http}: / /$ tabnet.datasus.gov.br/cgi/idb2012/c01.htm

${ }^{29} \mathrm{http}: / /$ tabnet.datasus.gov.br/cgi/idb2012/matriz.htm\#recur

${ }^{30} \mathrm{http} / / /$ ideb.inep.gov.br/
} 
Tabela 14 - Variáveis, fontes de dados e limitações da hipótese 6

\begin{tabular}{|c|c|c|c|}
\hline Fase & Variável & $\begin{array}{c}\text { Fonte do } \\
\text { Dado }\end{array}$ & Limitação \\
\hline \multirow{5}{*}{1} & Quantidade de Veículos Automotores & DENATRAN $^{31}$ & $\begin{array}{c}\text { Dados disponíveis a contar de } \\
1998 .\end{array}$ \\
\hline & $\begin{array}{c}\text { Imposto sobre Propriedade de Veículos } \\
\text { Automotores - IPVA }\end{array}$ & STN & - \\
\hline & Área da UF em km² & $\mathrm{IBGE}^{32}$ & $\begin{array}{l}\text { Não foi possível segregar em } \\
\text { área urbana e rural }{ }^{33} \text {. }\end{array}$ \\
\hline & Imposto Predial Territorial Urbano - IPTU & STN & - \\
\hline & Imposto Territorial Rural - ITR & STN & - \\
\hline \multirow{3}{*}{2} & $\begin{array}{l}\text { Coeficiente de Gini, Coeficiente de Theil-T, } \\
\text { Relação entre os } 10 \% \text { mais ricos e os } 40 \% \\
\text { mais pobres, Relação entre os } 20 \% \text { mais } \\
\text { ricos e os } 20 \% \text { mais pobres }\end{array}$ & IPEADATA & $\begin{array}{l}\text { Para dados ausentes referentes } \\
\text { aos anos de } 2010 \text { e } 2000 \text { foi } \\
\text { utilizada interpolação } \\
\text { exponencial. }\end{array}$ \\
\hline & Recursos de royalties do petróleo & ANP & $\begin{array}{c}\text { Dados de } 1995 \text { e } 1996 \\
\text { ausentes }\end{array}$ \\
\hline & Recursos de royalties do setor elétrico & ANEELL & $\begin{array}{c}\text { Dados de } 1995 \text { e } 1996 \\
\text { ausentes }\end{array}$ \\
\hline
\end{tabular}

Fonte: Elaborado pelo autor

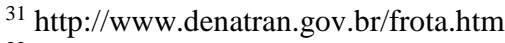

${ }^{32} \mathrm{http} / / / \mathrm{www} . i b g e . g o v . b r / h o m e / g e o c i e n c i a s /$ areaterritorial/principal.shtm

33 O IBGE no pedido de acesso a informação número 03950001146201516 formulado em 29/06/2015 no âmbito deste estudo, respondeu que a distinção entre zonas urbana e rural é de competência dos municípios, que o delimitam legalmente através da definição de perímetro urbano. Face a grandiosidade territorial, com 5570 municípios brasileiros, nem sempre o IBGE obtém êxito em extrair as informações. Desta forma, as precisas áreas urbanas e rurais podem ser obtidas somente através das prefeituras, através de seus dispositivos legais de definição de perímetros urbanos.
} 


\section{$\underline{\text { 3.1.3 Estatística descritiva das variáveis }}$}

O Quadro a seguir contém as estatísticas descritivas as variáveis utilizadas considerando as limitações expostas nas Tabelas 9 a 14.

Quadro 13 - Estatística Descritiva das Variáveis do Estudo

\begin{tabular}{|c|c|c|c|c|c|c|c|c|c|c|c|c|c|c|c|c|c|c|c|}
\hline Variável & Medidas & 1995 & 1996 & 1997 & 1998 & 1999 & 2000 & 2001 & 2002 & 2003 & 2004 & 2005 & 2006 & 2007 & 2008 & 2009 & 2010 & 2011 & 2012 \\
\hline \multirow{3}{*}{$\begin{array}{l}\text { Despesas com } \\
\text { Saúde nos } \\
\text { Estados* }\end{array}$} & Mediana & 98 & 105 & 132 & 170 & 153 & 149 & 294 & 312 & 370 & 476 & 671 & 782 & 851 & 1,020 & 1,200 & 1.391 & 1.445 & 1.626 \\
\hline & Média & 245 & 223 & 262 & 301 & 326 & 398 & 564 & 642 & 735 & 966 & 1.109 & 1.267 & 1.407 & 1.666 & 1.875 & 2.063 & 2.266 & 2.539 \\
\hline & $\begin{array}{l}\text { Desvio } \\
\text { Padrão }\end{array}$ & 474 & 336 & 345 & 503 & 555 & 648 & 773 & 893 & 1.083 & 1.491 & 1.605 & 1.792 & 1.936 & 2.303 & 2.555 & 2.739 & 3.034 & 3.240 \\
\hline \multirow{3}{*}{$\begin{array}{c}\text { Despesas com } \\
\text { Educação nos } \\
\text { Estados* }\end{array}$} & Mediana & 246 & 285 & 291 & 382 & 411 & 451 & 562 & 605 & 576 & 699 & 731 & 837 & 916 & 1,097 & 1,191 & 1,395 & 1,618 & 1,771 \\
\hline & Média & 516 & 616 & 573 & 819 & 887 & 1.004 & 1.169 & 1.309 & 1.440 & 1.443 & 1.591 & 1.807 & 2.020 & 2.483 & 2.614 & 2.788 & 3.336 & 3.309 \\
\hline & $\begin{array}{l}\text { Desvio } \\
\text { Padrão }\end{array}$ & 819 & 983 & 735 & 1,220 & 1.305 & 1.551 & 1.967 & 2.237 & 2.466 & 2.583 & 2.870 & 3.206 & 3.517 & 4.249 & 4.329 & 4.220 & 5.723 & 4.886 \\
\hline \multirow{3}{*}{$\begin{array}{l}\text { Despesas com } \\
\text { Saúde nos } \\
\text { Municípios* }\end{array}$} & Mediana & 94 & 92 & 125 & 132 & 151 & 236 & 311 & 335 & 417 & 504 & 620 & 726 & 848 & 1.045 & 1.161 & 1.335 & 1.522 & 1,768 \\
\hline & Média & 242 & 259 & 292 & 391 & 442 & 574 & 646 & 813 & 945 & 1.071 & 1.270 & 1.515 & 1.727 & 2.084 & 2.333 & 2.625 & 3.010 & 3.378 \\
\hline & $\begin{array}{l}\text { Desvio } \\
\text { Padrão }\end{array}$ & 474 & 625 & 593 & 734 & 811 & 937 & 1.016 & 1.221 & 1.416 & 1.616 & 1.900 & 2.181 & 2.488 & 3.018 & 3.346 & 3.787 & 4.356 & 4.935 \\
\hline \multirow{3}{*}{$\begin{array}{l}\text { Despesas com } \\
\text { Educação nos } \\
\text { Municípios* }\end{array}$} & Mediana & 115 & 149 & 145 & 178 & 199 & 392 & 479 & 444 & 505 & 595 & 654 & 834 & 904 & 1.133 & 1.147 & 1.413 & 1.536 & 1.858 \\
\hline & Média & 314 & 363 & 380 & 540 & 610 & 799 & 910 & 984 & 1.111 & 1.206 & 1.418 & 1.693 & 1.979 & 2.365 & 2.565 & 2.972 & 3.408 & 3.774 \\
\hline & $\begin{array}{l}\text { Desvio } \\
\text { Padrão }\end{array}$ & 585 & 654 & 704 & 905 & 1.028 & 1.236 & 1.388 & 1.446 & 1.677 & 1.830 & 2.149 & 2.455 & 2.924 & 3.470 & 3.710 & 4.368 & 4.843 & 5.373 \\
\hline \multirow{3}{*}{$\begin{array}{c}\text { Imposto de } \\
\text { Renda* }\end{array}$} & Mediana & 203 & 232 & 270 & 300 & 337 & 350 & 350 & 565 & 782 & 695 & 784 & 915 & 1.007 & 1.245 & 1.315 & 1.438 & 203 & 232 \\
\hline & Média & 1.294 & 1.478 & 1.666 & 1.883 & 2.130 & 2.198 & 2.479 & 3.380 & 3.691 & 4.101 & 4.945 & 5.485 & 6.403 & 7.664 & 7.655 & 8.397 & 1.294 & 1.478 \\
\hline & $\begin{array}{l}\text { Desvio } \\
\text { Padrão } \\
\end{array}$ & 3.281 & 3.703 & 4.180 & 4.717 & 5.318 & 5.567 & 6.391 & 8.261 & 8.817 & 9.627 & 11.563 & 12.851 & 15.092 & 17.939 & 17.681 & 18.747 & 3.281 & 3.703 \\
\hline \multirow{3}{*}{$\begin{array}{c}\text { Imposto } \\
\text { Territorial } \\
\text { Rural* }\end{array}$} & Mediana & 3 & 3 & 3 & 4 & 3 & 7 & 4 & 20 & 5 & 5 & 5 & 5 & 6 & 9 & 14 & 8 & 10.41 & 14.66 \\
\hline & Média & 8 & 9 & 9 & 12 & 15 & 15 & 13 & 31 & 20 & 18 & 20 & 22 & 25 & 30 & 36 & 44 & 48.13 & 55.81 \\
\hline & $\begin{array}{l}\text { Desvio } \\
\text { Padrão }\end{array}$ & 12 & 13 & 13 & 17 & 23 & 20 & 18 & 35 & 26 & 26 & 27 & 33 & 38 & 41 & 48 & 62 & 66.95 & 78.29 \\
\hline \multirow{3}{*}{ IPVA* } & Mediana & 3 & 3 & 3 & 4 & 3 & 7 & 4 & 20 & 5 & 5 & 5 & 5 & 6 & 9 & 14 & 8 & 10 & 15 \\
\hline & Média & 8 & 9 & 9 & 12 & 15 & 15 & 13 & 31 & 20 & 18 & 20 & 22 & 25 & 30 & 36 & 44 & 48 & 56 \\
\hline & $\begin{array}{l}\text { Desvio } \\
\text { Padrão }\end{array}$ & 12 & 13 & 13 & 17 & 23 & 20 & 18 & 35 & 26 & 26 & 27 & 33 & 38 & 41 & 48 & 62 & 67 & 78 \\
\hline \multirow{3}{*}{ ITCMD* } & Mediana & 1 & 1 & 1 & 2 & 2 & 2 & 2 & 1 & 5 & 5 & 6 & 7 & 8 & 15 & 18 & 21 & 25 & 32 \\
\hline & Média & 7 & 9 & 11 & 13 & 12 & 14 & 12 & 19 & 32 & 27 & 30 & 36 & 45 & 55 & 62 & 93 & 102 & 126 \\
\hline & $\begin{array}{l}\text { Desvio } \\
\text { Padrão }\end{array}$ & 20 & 27 & 32 & 40 & 36 & 41 & 25 & 49 & 103 & 67 & 70 & 87 & 103 & 123 & 141 & 207 & 213 & 265 \\
\hline
\end{tabular}




\begin{tabular}{|c|c|c|c|c|c|c|c|c|c|c|c|c|c|c|c|c|c|c|c|}
\hline Variável & Medidas & 1995 & 1996 & 1997 & 1998 & 1999 & 2000 & 2001 & 2002 & 2003 & 2004 & 2005 & 2006 & 2007 & 2008 & 2009 & 2010 & 2011 & 2012 \\
\hline \multirow{3}{*}{ ITBI* } & Mediana & 5 & 4 & 4 & 10 & 11 & 15 & 18 & 20 & 21 & 23 & 27 & 34 & 41 & 53 & 50 & 71 & 101 & 125 \\
\hline & Média & 24 & 28 & 33 & 34 & 37 & 43 & 47 & 57 & 60 & 64 & 75 & 91 & 118 & 149 & 155 & 206 & 254 & 293 \\
\hline & $\begin{array}{l}\text { Desvio } \\
\text { Padrão }\end{array}$ & 54 & 63 & 70 & 71 & 77 & 89 & 98 & 113 & 112 & 118 & 142 & 177 & 235 & 288 & 284 & 390 & 478 & 537 \\
\hline \multirow{3}{*}{ IPTU* } & Mediana & 19 & 20 & 19 & 20 & 20 & 23 & 25 & 29 & 32 & 37 & 43 & 49 & 63 & 61 & 70 & 81 & 115 & 143 \\
\hline & Média & 103 & 126 & 134 & 148 & 180 & 203 & 220 & 258 & 300 & 336 & 367 & 403 & 440 & 476 & 525 & 606 & 681 & 750 \\
\hline & $\begin{array}{l}\text { Desvio } \\
\text { Padrão }\end{array}$ & 268 & 337 & 356 & 386 & 501 & 563 & 620 & 719 & 836 & 934 & 1.023 & 1.119 & 1.211 & 1.284 & 1.414 & 1.634 & 1.835 & 2.019 \\
\hline \multirow{3}{*}{$\begin{array}{c}\text { Bolsa } \\
\text { Família* }\end{array}$} & Mediana & - & - & - & - & - & - & - & - & - & 13 & 15 & 19 & 23 & 25 & 31 & 33 & 43 & 57 \\
\hline & Média & - & - & - & - & - & - & - & - & - & 16 & 20 & 25 & 31 & 34 & 43 & 46 & 59 & 75 \\
\hline & $\begin{array}{l}\text { Desvio } \\
\text { Padrão }\end{array}$ & - & - & - & - & - & - & - & - & - & 16 & 19 & 24 & 28 & 31 & 39 & 41 & 53 & 66 \\
\hline \multirow{3}{*}{$\begin{array}{c}\text { BPC ao } \\
\text { Idoso* }\end{array}$} & Mediana & - & 0,1 & 0,3 & 1 & 1 & 1 & 2 & 2 & 3 & 4 & 6 & 9 & 11 & 12 & 15 & 17 & 19 & 23 \\
\hline & Média & - & 0,2 & 0,4 & 1 & 2 & 2 & 3 & 4 & 6 & 9 & 12 & 15 & 18 & 22 & 27 & 31 & 34 & 40 \\
\hline & $\begin{array}{l}\text { Desvio } \\
\text { Padrão }\end{array}$ & - & 0,2 & 0,5 & 1 & 2 & 3 & 4 & 5 & 7 & 11 & 14 & 18 & 21 & 25 & 30 & 35 & 38 & 46 \\
\hline \multirow{3}{*}{$\begin{array}{c}\text { BPC ao } \\
\text { deficiente* }^{*}\end{array}$} & Mediana & - & 0,9 & 2 & 2 & 3 & 3 & 4 & 5 & 6 & 7 & 9 & 11 & 13 & 15 & 18 & 21 & 23 & 28 \\
\hline & Média & - & 1 & 3 & 3 & 4 & 5 & 6 & 7 & 9 & 11 & 14 & 17 & 20 & 23 & 28 & 34 & 38 & 46 \\
\hline & $\begin{array}{l}\text { Desvio } \\
\text { Padrão }\end{array}$ & - & 1 & 3 & 3 & 4 & 5 & 6 & 7 & 9 & 10 & 13 & 16 & 18 & 21 & 25 & 30 & 35 & 42 \\
\hline \multirow{3}{*}{$\begin{array}{l}\text { Royalties } \\
\text { Petróleo* }\end{array}$} & Mediana & - & - & - & 0 & 0 & 0 & 0 & 0 & 0 & 0 & 0 & 0 & 0 & 0 & 0 & 0 & 0 & 0 \\
\hline & Média & - & - & - & 1 & 15 & 24 & 28 & 42 & 52 & 52 & 76 & 89 & 79 & 135 & 93 & 112 & 138 & 173 \\
\hline & $\begin{array}{l}\text { Desvio } \\
\text { Padrão }\end{array}$ & - & - & - & 3 & 46 & 76 & 88 & 144 & 176 & 173 & 266 & 320 & 277 & 479 & 348 & 396 & 462 & 584 \\
\hline \multirow{3}{*}{$\begin{array}{l}\text { Royalties } \\
\text { Setor } \\
\text { Elétrico* }\end{array}$} & Mediana & - & - & 0 & 0 & 0 & 1 & 1 & 2 & 3 & 4 & 5 & 6 & 6 & 6 & 7 & 7 & 7 & 10 \\
\hline & Média & - & - & 8 & 8 & 10 & 11 & 14 & 17 & 19 & 20 & 22 & 23 & 25 & 25 & 28 & 29 & 30 & 34 \\
\hline & $\begin{array}{l}\text { Desvio } \\
\text { Padrão }\end{array}$ & - & - & 19 & 21 & 30 & 31 & 40 & 48 & 50 & 48 & 46 & 45 & 46 & 47 & 52 & 52 & 52 & 61 \\
\hline \multirow{3}{*}{ Médicos } & Mediana & 2.833 & 2.900 & 3.270 & 3.272 & 3.306 & 3.153 & 3.252 & 3.345 & 3.553 & 3.920 & 4.104 & 4.135 & 4.271 & 4.485 & 4.771 & 4.479 & 4.886 & 5.259 \\
\hline & Média & 7.351 & 7.655 & 7.995 & 8.023 & 8.765 & 8.795 & 9.119 & 9.463 & 9.932 & 10.815 & 11.487 & 11.852 & 12.187 & 12.661 & 13.049 & 13.148 & 13.770 & 14.259 \\
\hline & $\begin{array}{l}\text { Desvio } \\
\text { Padrão }\end{array}$ & 12.869 & 13.467 & 14.133 & 14.417 & 15.689 & 15.511 & 16.050 & 16.656 & 17.412 & 18.257 & 19.241 & 19.736 & 20.202 & 20.950 & 21.199 & 21.827 & 22.449 & 23.248 \\
\hline
\end{tabular}




\begin{tabular}{|c|c|c|c|c|c|c|c|c|c|c|c|c|c|c|c|c|c|c|c|}
\hline Variável & Medidas & 1995 & 1996 & 1997 & 1998 & 1999 & 2000 & 2001 & 2002 & 2003 & 2004 & 2005 & 2006 & 2007 & 2008 & 2009 & 2010 & 2011 & 2012 \\
\hline \multirow{3}{*}{$\begin{array}{c}\text { Leitos do } \\
\text { Sistema } \\
\text { Único de } \\
\text { Saúde }\end{array}$} & Mediana & 2.332 & 2.202 & 2.560 & 2.817 & 3.018 & 3.052 & 3.267 & 3.217 & 3.279 & 4.823 & 7.398 & 7.396 & 7.352 & 7.390 & 7.405 & 7.214 & 7.028 & 7.071 \\
\hline & Média & 4.099 & 4.044 & 4.246 & 4.236 & 4.370 & 4.416 & 4.770 & 4.738 & 5.129 & 7.998 & 13.136 & 13.073 & 12.996 & 12.857 & 12.787 & 12.482 & 12.318 & 12.142 \\
\hline & $\begin{array}{l}\text { Desvio } \\
\text { Padrão }\end{array}$ & 5.188 & 5.033 & 5.196 & 5.138 & 5.185 & 5.145 & 6.053 & 5.903 & 6.481 & 9.380 & 14.230 & 14.120 & 13.944 & 13.817 & 13.713 & 13.314 & 13.107 & 12.861 \\
\hline \multirow{3}{*}{$\begin{array}{l}\text { Matrículas } \\
\text { no ensino } \\
\text { público** }\end{array}$} & Mediana & 471 & 453 & 453 & 453 & 440 & 441 & 454 & 451 & 482 & 447 & 438 & 439 & 434 & 430 & 434 & 436 & 428 & 396 \\
\hline & Média & 863 & 874 & 873 & 853 & 858 & 846 & 823 & 810 & 819 & 770 & 744 & 728 & 694 & 677 & 660 & 643 & 628 & 602 \\
\hline & $\begin{array}{l}\text { Desvio } \\
\text { Padrão }\end{array}$ & 1,286 & 1,265 & 1,216 & 1,181 & 1,145 & 1,122 & 1,059 & 1,020 & 980 & 957 & 926 & 904 & 872 & 859 & 841 & 834 & 822 & 798 \\
\hline \multirow{3}{*}{$\begin{array}{l}\text { Professores } \\
\text { no ensino } \\
\text { público** }\end{array}$} & Mediana & 18 & 19 & 17 & 18 & 18 & 18 & 18 & 18 & 19 & 19 & 19 & 19 & 15 & 16 & 16 & 17 & 19 & 18 \\
\hline & Média & 36 & 35 & 34 & 33 & 34 & 35 & 35 & 35 & 36 & 34 & 36 & 36 & 29 & 30 & 30 & 30 & 33 & 32 \\
\hline & $\begin{array}{l}\text { Desvio } \\
\text { Padrão }\end{array}$ & 50 & 48 & 46 & 44 & 43 & 34 & 45 & 45 & 47 & 33 & 48 & 50 & 38 & 39 & 38 & 38 & 43 & 43 \\
\hline \multirow{3}{*}{$\begin{array}{l}\text { Docentes por } \\
\text { alunos } \\
\text { matriculados } \\
\text { no ensino } \\
\text { público até a } \\
5^{\mathbf{a}} \text { série } \\
\text { Ensino } \\
\text { Fundamental }\end{array}$} & Mediana & - & - & - & - & - & - & - & - & - & - & 24,58 & 23,84 & 27,71 & 26,83 & 26,18 & 25,78 & 22,21 & 21,76 \\
\hline & Média & - & - & - & - & - & - & - & - & - & - & 24,68 & 24,12 & 28,06 & 27,24 & 27,39 & 26,53 & 23,29 & 22,86 \\
\hline & $\begin{array}{l}\text { Desvio } \\
\text { Padrão }\end{array}$ & - & - & - & - & - & - & - & - & - & - & 4,55 & 4,93 & 5,90 & 5,69 & 6,16 & 6,08 & 5,30 & 5,52 \\
\hline \multirow{3}{*}{$\begin{array}{c}\text { IDEB 5 } 5^{\mathrm{a}} \\
\text { Série Ensino } \\
\text { Fundamental }\end{array}$} & Mediana & - & - & - & - & - & - & - & - & - & - & 3,60 & 3,80 & 3,80 & 4,40 & 4,40 & 4,70 & 4,70 & 5,10 \\
\hline & Média & - & - & - & - & - & - & - & - & - & - & 5,16 & 3,85 & 3,85 & 4,35 & 4,35 & 4,61 & 4,61 & 4,89 \\
\hline & $\begin{array}{l}\text { Desvio } \\
\text { Padrão }\end{array}$ & - & - & - & - & - & - & - & - & - & - & 5,85 & 0,69 & 0,69 & 0,69 & 0,69 & 0,67 & 0,67 & 0,78 \\
\hline \multirow{3}{*}{$\begin{array}{c}\text { Docentes por } \\
\text { alunos } \\
\text { matriculados } \\
\text { no ensino } \\
\text { público até a } \\
9^{\mathbf{a}} \text { série } \\
\text { Ensino } \\
\text { Fundamental }\end{array}$} & Mediana & - & - & - & - & - & - & - & - & - & - & 20,49 & 19,40 & 24,02 & 22,15 & 22,50 & 21,67 & 18,14 & 17,68 \\
\hline & Média & - & - & - & - & - & - & - & - & - & - & 20,77 & 20,18 & 24,39 & 22,66 & 22,89 & 22,32 & 18,66 & 18,19 \\
\hline & $\begin{array}{l}\text { Desvio } \\
\text { Padrão }\end{array}$ & - & - & - & - & - & - & - & - & - & - & 3,89 & 3,84 & 5,39 & 4,63 & 4,52 & 4,32 & 3,61 & 3,77 \\
\hline
\end{tabular}




\begin{tabular}{|c|c|c|c|c|c|c|c|c|c|c|c|c|c|c|c|c|c|c|c|}
\hline Variável & Medidas & 1995 & 1996 & 1997 & 1998 & 1999 & 2000 & 2001 & 2002 & 2003 & 2004 & 2005 & 2006 & 2007 & 2008 & 2009 & 2010 & 2011 & 2012 \\
\hline \multirow{3}{*}{$\begin{array}{c}\text { IDEB 9a } \\
\text { Série Ensino } \\
\text { Fundamental }\end{array}$} & Mediana & - & - & - & - & - & - & - & - & - & - & 3,20 & 3,40 & 3,40 & 3,60 & 3,60 & 3,60 & 3,60 & 3,70 \\
\hline & Média & - & - & - & - & - & - & - & - & - & - & 3,10 & 3,33 & 3,33 & 3,54 & 3,54 & 3,62 & 3,62 & 3,70 \\
\hline & $\begin{array}{l}\text { Desvio } \\
\text { Padrão }\end{array}$ & - & - & - & - & - & - & - & - & - & - & 0,44 & 0,44 & 0,44 & 0,50 & 0,50 & 0,54 & 0,54 & 0,53 \\
\hline \multirow{3}{*}{$\begin{array}{c}\text { Docentes por } \\
\text { alunos } \\
\text { matriculados } \\
\text { no Ensino } \\
\text { Médio } \\
\end{array}$} & Mediana & - & - & - & - & - & - & - & - & - & - & 21,60 & 21,43 & 23,46 & 21,00 & 19,79 & 19,08 & 18,35 & 17,93 \\
\hline & Média & - & - & - & - & - & - & - & - & - & - & 22,64 & 22,01 & 24,79 & 21,93 & 21,86 & 20,87 & 19,60 & 19,32 \\
\hline & $\begin{array}{l}\text { Desvio } \\
\text { Padrão }\end{array}$ & - & - & - & - & - & - & - & - & - & - & 4,98 & 4,99 & 6,78 & 4,80 & 5,48 & 4,89 & 4,54 & 4,81 \\
\hline \multirow{3}{*}{$\begin{array}{c}\text { IDEB Ensino } \\
\text { Médio }\end{array}$} & Mediana & - & - & - & - & - & - & - & - & - & - & 3,20 & 3,40 & 3,40 & 3,60 & 3,60 & 3,60 & 3,60 & 3,70 \\
\hline & Média & - & - & - & - & - & - & - & - & - & - & 3,10 & 3,33 & 3,33 & 3,54 & 3,54 & 3,62 & 3,62 & 3,70 \\
\hline & $\begin{array}{l}\text { Desvio } \\
\text { Padrão }\end{array}$ & - & - & - & - & - & - & - & - & - & - & 0,44 & 0,44 & 0,44 & 0,50 & 0,50 & 0,54 & 0,54 & 0,53 \\
\hline \multirow{3}{*}{$\begin{array}{l}\text { Médicos por } \\
\text { habitante }\end{array}$} & Mediana & 0,0008 & 0,0009 & 0,0009 & 0,0010 & 0,0010 & 0,0009 & 0,0009 & 0,0009 & 0,0010 & 0,0011 & 0,0011 & 0,0011 & 0,0012 & 0,0012 & 0,0014 & 0,0012 & 0,0013 & 0,0014 \\
\hline & Média & 0,0009 & 0,0010 & 0,0010 & 0,0010 & 0,0011 & 0,0010 & 0,0011 & 0,0011 & 0,0011 & 0,0013 & 0,0014 & 0,0014 & 0,0014 & 0,0015 & 0,0015 & 0,0015 & 0,0016 & 0.0016 \\
\hline & $\begin{array}{l}\text { Desvio } \\
\text { Padrão }\end{array}$ & 0,0006 & 0,0006 & 0,0006 & 0,0006 & 0,0007 & 0,0007 & 0,0007 & 0,0007 & 0,0007 & 0,0007 & 0,0007 & 0,0007 & 0,0007 & 0,0007 & 0,0007 & 0,0008 & 0,0008 & 0,0008 \\
\hline \multirow{3}{*}{$\begin{array}{c}\text { Leitos do } \\
\text { Sistema } \\
\text { Único de } \\
\text { Saúde por } \\
\text { pessoa } \\
\end{array}$} & Mediana & 0,0007 & 0,0008 & 0,0008 & 0,0009 & 0,0008 & 0,0007 & 0,0009 & 0,0008 & 0,0009 & 0,0013 & 0,0019 & 0,0018 & 0,0019 & 0,0018 & 0,0018 & 0,0018 & 0,0018 & 0,0017 \\
\hline & Média & 0,0010 & 0,0010 & 0,0010 & 0,0010 & 0,0011 & 0,0010 & 0,0011 & 0,0011 & 0,0011 & 0,0013 & 0,0014 & 0,0014 & 0,0014 & 0,0015 & 0,0015 & 0,0015 & 0,0016 & 0,0016 \\
\hline & $\begin{array}{l}\text { Desvio } \\
\text { Padrão }\end{array}$ & 0,0008 & 0,0008 & 0,0007 & 0,0007 & 0,0006 & 0,0005 & 0,0005 & 0,0005 & 0,0005 & 0,0004 & 0,0003 & 0,0003 & 0,0003 & 0,0003 & 0,0003 & 0,0003 & 0,0002 & 0,0002 \\
\hline \multirow{3}{*}{$\begin{array}{c}\text { Taxa de } \\
\text { sobrevivência }\end{array}$} & Mediana & 83,92 & 87,18 & 87,75 & 87,53 & 89,28 & 90,29 & 89,92 & 91,06 & 90,27 & 91,43 & 91,73 & 92,57 & 93,27 & 93,70 & 94,09 & 94,76 & 94,80 & 95,66 \\
\hline & Média & 82,64 & 84,88 & 86,51 & 86,72 & 88,60 & 89,53 & 90,34 & 91,13 & 91,27 & 91,89 & 92,36 & 92,85 & 93,40 & 93,78 & 94,01 & 94,55 & 94,79 & 95,44 \\
\hline & $\begin{array}{l}\text { Desvio } \\
\text { Padrão } \\
\end{array}$ & 8,65 & 7,35 & 6,22 & 6,02 & 4,97 & 3,99 & 3,49 & 3,04 & 2,94 & 2,64 & 2,52 & 2,58 & 1,91 & 1,68 & 1,69 & 1,50 & 1,36 & 1,11 \\
\hline \multirow{3}{*}{$\begin{array}{l}\text { Expectativa } \\
\text { de Vida }\end{array}$} & Mediana & 67,72 & 68,09 & 68,46 & 68,83 & 69,19 & 68,69 & 69,05 & 69,40 & 69,74 & 70,08 & 70,40 & 70,72 & 71,03 & 71,41 & 71,78 & 72,13 & 72,47 & 72,78 \\
\hline & Média & 67,72 & 68,09 & 68,46 & 68,82 & 69,18 & 68,75 & 69,25 & 69,66 & 70,06 & 70,45 & 70,82 & 71,19 & 71,55 & 71,90 & 72,24 & 72,57 & 72,89 & 73,19 \\
\hline & $\begin{array}{l}\text { Desvio } \\
\text { Padrão }\end{array}$ & 2,93 & 2,88 & 2,83 & 2,79 & 2,74 & 2,45 & 2,36 & 2,37 & 2,39 & 2,41 & 2,43 & 2,46 & 2,48 & 2,51 & 2,54 & 2,57 & 2,59 & 2,62 \\
\hline \multirow{3}{*}{$\begin{array}{c}\text { Quantidade } \\
\text { de Veículos } \\
\text { Automotores } \\
\text { t* }^{*}\end{array}$} & Mediana & - & - & - & 288,16 & 329,35 & 380,52 & 421,18 & 475,98 & 519,99 & 566,89 & 614.97 & 663,97 & 730,57 & 807,12 & 883,39 & 972,53 & $1.109,26$ & $1.265,83$ \\
\hline & Média & - & - & - & 902,27 & $1.006,38$ & $1.100,85$ & $1.181,96$ & $1.269,81$ & $1.357,72$ & $1.453,37$ & $1.558,22$ & $1.680,47$ & $1.838,67$ & $2.018,77$ & $2.198,58$ & $2.400,67$ & $2.612,72$ & $2.819,90$ \\
\hline & $\begin{array}{l}\text { Desvio } \\
\text { Padrão }\end{array}$ & - & - & - & $1.764,50$ & $1.948,66$ & $2.102,68$ & $2.238,75$ & $2.371,71$ & $2.499,13$ & $2.638,58$ & $2.797,27$ & $2.992,84$ & $3.241,15$ & $3.512,63$ & $3.763,54$ & $4.037,04$ & $4.318,54$ & $4.581,21$ \\
\hline
\end{tabular}




\begin{tabular}{|c|c|c|c|c|c|c|c|c|c|c|c|c|c|c|c|c|c|c|c|}
\hline Variável & Medidas & 1995 & 1996 & 1997 & 1998 & 1999 & 2000 & 2001 & 2002 & 2003 & 2004 & 2005 & 2006 & 2007 & 2008 & 2009 & 2010 & 2011 & 2012 \\
\hline \multirow{3}{*}{$\begin{array}{c}\text { Área da UF } \\
\text { em km² } \\
\text { Líquida }\end{array}$} & Mediana & \multicolumn{18}{|c|}{$223.057,56$} \\
\hline & Média & \multicolumn{18}{|c|}{$308.859,75$} \\
\hline & $\begin{array}{l}\text { Desvio } \\
\text { Padrão }\end{array}$ & \multicolumn{18}{|c|}{$354.686,49$} \\
\hline \multirow{3}{*}{$\begin{array}{c}\text { Coeficiente de } \\
\text { Gini }\end{array}$} & Mediana & 0,581 & 0,584 & 0,585 & 0,579 & 0,564 & 0,573 & 0,572 & 0,563 & 0,560 & 0,550 & 0,554 & 0,545 & 0,546 & 0,539 & 0,523 & 0,515 & 0,524 & 0,523 \\
\hline & Média & 0,575 & 0,580 & 0,582 & 0,581 & 0,575 & 0,573 & 0,574 & 0,571 & 0,560 & 0,557 & 0,549 & 0,546 & 0,544 & 0,532 & 0,535 & 0,513 & 0,520 & 0,517 \\
\hline & $\begin{array}{l}\text { Desvio } \\
\text { Padrão }\end{array}$ & 0,040 & 0,043 & 0,040 & 0,032 & 0,034 & 0,041 & 0,035 & 0,032 & 0,033 & 0,035 & 0,032 & 0,039 & 0,037 & 0,037 & 0,038 & 0,038 & 0,034 & 0,037 \\
\hline \multirow{3}{*}{$\begin{array}{c}\text { Coeficiente de } \\
\text { Theil }\end{array}$} & Mediana & 0,680 & 0,704 & 0,722 & 0,712 & 0,650 & 0,707 & 0,694 & 0,660 & 0,631 & 0,637 & 0,613 & 0,612 & 0,607 & 0,572 & 0,564 & 0,526 & 0,555 & 0,541 \\
\hline & Média & 0,694 & 0,702 & 0,716 & 0,707 & 0,680 & 0,703 & 0,693 & 0,683 & 0,641 & 0,650 & 0,625 & 0,629 & 0,611 & 0,584 & 0,592 & 0,536 & 0,552 & 0,581 \\
\hline & $\begin{array}{l}\text { Desvio } \\
\text { Padrão }\end{array}$ & 0,126 & 0,133 & 0,130 & 0,108 & 0,108 & 0,124 & 0,104 & 0,104 & 0,095 & 0,101 & 0,095 & 0,132 & 0,106 & 0,097 & 0,102 & 0,097 & 0,085 & 0,169 \\
\hline \multirow{3}{*}{$\begin{array}{c}\text { Proporção } \\
\text { entre os 10\% } \\
\text { mais ricos e os } \\
40 \% \text { mais } \\
\text { pobres } \\
\end{array}$} & Mediana & 20,67 & 20,87 & 20,99 & 21,00 & 18,69 & 19,61 & 19,44 & 18,24 & 18,17 & 17,10 & 17,26 & 16,36 & 16,81 & 15,97 & 14,62 & 14,06 & 14,82 & 14,30 \\
\hline & Média & 20,26 & 21,17 & 21,22 & 20,95 & 20,46 & 20,19 & 20,15 & 19,58 & 18,70 & 18,17 & 17,31 & 17,02 & 17,04 & 15,87 & 16,14 & 14,16 & 14,73 & 14,48 \\
\hline & $\begin{array}{l}\text { Desvio } \\
\text { Padrão }\end{array}$ & 4,01 & 5,01 & 4,32 & 3,79 & 4,70 & 4,67 & 4,10 & 3,90 & 4,10 & 4,00 & 3,34 & 3,97 & 4,03 & 3,65 & 4,00 & 3,10 & 3,00 & 3,14 \\
\hline \multirow{3}{*}{$\begin{array}{c}\text { Proporção } \\
\text { entre os 20\% } \\
\text { mais ricos e os } \\
20 \% \text { mais } \\
\text { pobres }\end{array}$} & Mediana & 22,37 & 22,38 & 22,97 & 22,71 & 20,58 & 21,47 & 21,78 & 19,87 & 19,50 & 18,24 & 17,90 & 16,98 & 17,92 & 16,68 & 16,49 & 15,29 & 16,26 & 15,47 \\
\hline & Média & 22,07 & 23,67 & 23,46 & 22,80 & 22,40 & 22,38 & 22,22 & 20,88 & 20,65 & 19,66 & 18,36 & 17,93 & 19,02 & 17,13 & 17,52 & 15,82 & 16,27 & 15,64 \\
\hline & $\begin{array}{l}\text { Desvio } \\
\text { Padrão }\end{array}$ & 4,58 & 6,24 & 5,22 & 4,04 & 5,23 & 5,24 & 4,50 & 4,47 & 5,45 & 5,36 & 3,87 & 4,46 & 5,11 & 4,14 & 4,44 & 4,06 & 3,65 & 3,71 \\
\hline \multirow{3}{*}{$\begin{array}{l}\text { PIB dos } \\
\text { Estados* }\end{array}$} & Mediana & 10,069 & 12,495 & 12,572 & 13,199 & 13,934 & 16,750 & 18,050 & 21,791 & 27,889 & 35,563 & 37,466 & 39,157 & 42,687 & 53,386 & 57,294 & 59,779 & 71,418 & 80,830 \\
\hline & Média & 26,135 & 31,258 & 34,783 & 36,269 & 39,444 & 43,685 & 48,227 & 54,734 & 62,961 & 71,907 & 79,527 & 87,759 & 98,568 & 112,304 & 119,978 & 139,633 & 153,445 & 162,670 \\
\hline & $\begin{array}{l}\text { Desvio } \\
\text { Padrão }\end{array}$ & 51,337 & 60,161 & 67,317 & 69,204 & 75,237 & 83,133 & 90,824 & 100,472 & 113,776 & 127,044 & 142,810 & 157,716 & 176,900 & 197,284 & 211,979 & 244,404 & 264,938 & 277,358 \\
\hline
\end{tabular}

Legenda: *valores em R \$ 1.000 .000 (milhões). ** valores em milhares. 


\subsubsection{Técnicas de Análise Quantitativa e seus Pressupostos}

A análise econométrica será operacionalizada pela aplicação três técnicas de análise quantitativa de dados: modelo de regressão linear em painel - Mínimos Quadrados Ordinários (MQO); modelo tobit em painel e modelo de programação matemática análise envoltória de dados (DEA);

\subsubsection{Modelo de regressão linear em painel}

Nos dados em painel, a mesma unidade de corte transversal é acompanhada ao longo do tempo. Em síntese, os dados em painel têm uma dimensão espacial e outra dimensão temporal. A análise de dados em painel elabora um mix dessas duas abordagens uma vez que surgiu a necessidade de os pesquisadores trabalharem com bancos de dados que apresentassem características de cross-section e de séries de tempo (BALTAGI, 2005).

Um conjunto de dados em painel é aquele que segue uma determinada amostra de indivíduos ao longo do tempo, e fornece, assim, múltiplas observações sobre cada indivíduo na amostra.

Existem vantagens da análise de dados em painel: (i) pode-se evidenciar sistemas mais complexos de relacionamentos de variáveis de unidades de observação ao longo do tempo; (ii) pode-se aumentar o volume de dados para análise pelo empilhamento de séries, aumentando o número de graus de liberdade; (iii) a combinação de dados pode aumentar o poder dos testes estatísticos; (iv) a combinação de dados pode mitigar problemas de multicolinearidade (BALTAGI, 2005).

Os panéis podem ser balanceados quando se tem o mesmo número de observações temporais (T) para cada unidade de observação; e desbalanceados quando existem algumas unidades de observação com menos observações temporais do que outras. Considerando a base de dados, este estudo poderá utilizará painéis balanceados ou desbalanceados conforme as restrições das variáveis dependentes (BALTAGI, 2005).

Os painéis podem ser de efeitos fixos e de efeitos aleatórios. O Quadro 14 traz algumas diferenças. 
Quadro 14 - Efeitos fixos e aleatórios no painel

\begin{tabular}{|c|c|}
\hline Painel & Característica \\
\hline Fixo & $\begin{array}{l}\text {-Requer que o intercepto no modelo de regressão seja diferente para as unidades } \\
\text { de observação (i), mas não ao longo do tempo }(\mathrm{t}) \text {; } \\
\text {-Todas as estimativas de coeficientes de declividade são fixas para as unidades de } \\
\text { observação (i) e para o tempo (t); } \\
\text {-São mais apropriados, quando as unidades de observação na amostra constituem } \\
\text { a população inteira. }\end{array}$ \\
\hline Aleatório & $\begin{array}{l}\text {-Assume que as relações entre as variáveis dependentes e explicativas são as } \\
\text { mesmas ao longo das seções transversal (i) e longitudinal (t); } \\
\text { - Assume-se que os interceptos de cada unidade transversal (i) surgem a partir de } \\
\text { um intercepto a comum (que é o mesmo para todas as unidades de observação (i) } \\
\text { e ao longo do tempo (t)), adicionado de uma variável aleatória } e_{i} \text {, que varia } \\
\text { transversalmente, mas é constante ao longo do tempo; } \\
\text {-O termo } e_{i} \text { mede o desvio aleatório de cada termo de unidade de observação (i) do } \\
\text { termo a global; } \\
\text {-São mais apropriados, quando as unidades de observação na amostra tenham sido } \\
\text { selecionadas aleatoriamente. }\end{array}$ \\
\hline
\end{tabular}

Fonte: Adaptado de Baltagi (2005) e Brooks (2008).

O uso de dados em painel requer ainda o atendimento dos seguintes pressupostos:

(i) normalidade dos resíduos; (ii) homocedasticidade (a variância do erro é constante);

(iii) ausência de auto correlação (o erro de uma observação deve ser independente do erro de outra observação); (iv) linearidade; (ii) ausência de multicolinearidade (variáveis independentes possuem alta correlação ou relação linear) (BALTAGI, 2005).

O Quadro 15 mostra os testes a serem aplicados nos modelos que utilizarem dados em painel MQO. 
Quadro 15 - Testes a serem aplicados em um painel de MQO

\begin{tabular}{|c|c|c|}
\hline Objetivo & Teste utilizado & Hipóteses do Teste \\
\hline $\begin{array}{c}\text { Diagnosticar a existência de } \\
\text { painel }\end{array}$ & Chow & $\begin{array}{l}\text { H0: Os interceptos são comuns para todas as } \\
\text { cross-sections (Pooled); } \\
\text { H1: Os interceptos são diferentes para todas as } \\
\text { cross-sections (Painel fixo). }\end{array}$ \\
\hline \multirow{2}{*}{ Diagnosticar o tipo de painel } & Breusch-Pagan & $\begin{array}{l}\text { H0: a variância dos resíduos que refletem } \\
\text { diferenças individuais é nula (Pooled); } \\
\text { H1: a variância dos resíduos que refletem } \\
\text { diferenças individuais } \neq 0 \text { (Painel aleatório). }\end{array}$ \\
\hline & Hausman & $\begin{array}{l}\text { H0: o modelo de correção de erros é adequado } \\
\text { (Painel aleatório) } \\
\text { H1: o modelo de correção de erros não é adequado } \\
\text { (Painel fixo) }\end{array}$ \\
\hline $\begin{array}{l}\text { Diagnosticar a normalidade } \\
\text { dos resíduos }\end{array}$ & Jarque-Bera & $\begin{array}{l}\text { H0: o erro do modelo de regressão possui } \\
\text { distribuição normal } \\
\text { H1: o erro do modelo de regressão possui } \\
\text { distribuição não-normal }\end{array}$ \\
\hline $\begin{array}{c}\text { Diagnosticar a } \\
\text { homocedasticidade }\end{array}$ & White & $\begin{array}{l}\text { H0: a variância dos erros é constante. } \\
\text { H1: a variância dos erros não é constante. }\end{array}$ \\
\hline $\begin{array}{l}\text { Diagnosticar a ausência de } \\
\text { auto correlação serial dos } \\
\text { resíduos }\end{array}$ & Durbin Watson & $\begin{array}{l}\text { H0: a auto correlação é a nula. } \\
\text { H1: auto correlação é } \neq 0 \text {. }\end{array}$ \\
\hline $\begin{array}{l}\text { Diagnosticar a } \\
\text { multicolinearidade }\end{array}$ & $\begin{array}{c}\text { Fator de Inflação } \\
\text { da Variância } \\
\text { (FIV) }\end{array}$ & O FIV não deve exceder 10. \\
\hline
\end{tabular}

Fonte: Adaptado de Baltagi (2005) e Brooks (2008).

Legenda: Esse pressuposto pode ser relaxado com base no Teorema do Limite Central e na Lei dos Grandes Números (BROOKS, 2008).

Segundo Greene (1997), nos casos em que as observações não são extrações aleatórias de uma grande população, o modelo com efeitos fixos é mais apropriado. Porém, contrariando o autor, neste estudo, optou-se pelo modelo com efeitos aleatórios, na medida que se busca capturar o efeito das cinco regiões administrativas (Norte, Nordeste, Centro-Oeste, Sudeste e Sul) por variáveis dummies e que o modelo com efeitos fixos acusa multicolinearidade nos aplicativos: Gretl e Stata versão 13.

\subsubsection{Modelo tobit em painel}

Em seu trabalho pioneiro sobre a despesa das famílias em bens duradouros, Tobin (1958) usou um modelo de regressão que especificamente tomou em consideração o fato de que as despesas (a variável dependente de seu modelo de regressão) não poderiam ser negativas. Tobin denominou este tipo de modelo como modelo de variáveis dependentes limitadas ou censuradas ${ }^{34}$ (HSIAO, 2003). Segundo Greene (1997) pode-se expressar o modelo tobit conforme a notação da equação 10.

\footnotetext{
${ }^{34} \mathrm{O}$ modelo é chamado truncado se as observações fora de uma faixa específica estão totalmente perdidas, e é chamado censurada se podemos observar, pelo menos, algumas das variáveis explicativas (HSIAO, 2003).
} 
$y_{i}^{*}=\beta^{\prime} x_{i}+\varepsilon_{i}$

Em que $\varepsilon_{i}$ é o erro aleatório da equação; $\beta$ é o vetor de parâmetros e representa os coeficientes a serem estimados; $x_{i}$ representa as variáveis explicativas; e, $y_{i}^{*}$ é a variável dependente estimada. A variável $y_{i}$ que é efetivamente observada consta na equação 11 .

$\left\{\begin{array}{l}y_{i}=y_{i}^{*} \text { se } y_{i}^{*}<y_{i}^{c} \\ y_{i}=y_{i}^{c} \text { se } y_{i}^{*} \geq y_{i}^{c}\end{array}\right.$

Em que $y_{i}^{c}$ representa o valor da censura. Os modelos tobit utilizam estimadores de máxima verossimilhança (HSIAO, 2003). Dessa forma, segundo Greene (1997), o

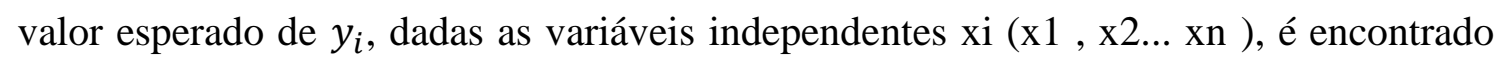
através da equação 12.

$$
\begin{aligned}
& E\left(y_{i} \mid \mathrm{x}_{i}\right)=\operatorname{Prob}\left(y_{i}=1\right) \times E\left(y_{i} \mid y_{i}=1\right)+\operatorname{Prob}\left(y_{i}<1\right) \times \\
& E\left(y_{i} \mid y_{i}<1\right)=x_{i} \beta \Phi\left(\frac{\beta x_{i}^{\prime}}{\sigma}\right)+\varphi\left(\frac{\beta x_{i}^{\prime}}{\sigma}\right)
\end{aligned}
$$

Em que $\sigma$ representa o desvio-padrão dos termos de erro; $\Phi$ e $\varphi$ representam, respectivamente, a função distribuição cumulativa normal e a função densidade normal avaliadas em $\frac{\beta x_{i}^{\prime}}{\sigma}$. A influência de cada variável explicativa incluída no modelo não é conhecida pela interpretação direta dos coeficientes do modelo, mas através da equação 13 (GREENE,1997). Assim, o efeito marginal das variáveis explicativas no valor esperado de yi é dado por:

$$
\frac{\partial E\left\lfloor y_{i} \mid x_{i}\right\rfloor}{\partial x_{i}}=\beta \phi\left(\frac{\beta^{\prime} x_{i}}{\sigma}\right)
$$

Dessa, forma conhecidos os efeitos marginais das variáveis incluídas no modelo, é possível determinar o impacto de cada uma delas sobre o indicador de desigualdade. $\mathrm{O}$ Quadro 16 mostra os testes a serem aplicados nos modelos que utilizarem dados em painel tobit. 
Quadro 16 - Testes a serem aplicados em um painel tobit

\begin{tabular}{|c|c|c|}
\hline Objetivo & Teste utilizado & Hipóteses do Teste \\
\hline Diagnosticar o tipo de painel & $\begin{array}{c}\text { Razão da Máxima } \\
\text { verossimilhança }\end{array}$ & $\begin{array}{l}\text { H0: a variância é zero e o componente } \\
\text { idiossincrático não explica a regressão } \\
\text { (Painel aleatório) } \\
\text { H1: a variância dos resíduos que refletem } \\
\text { diferenças individuais } \neq 0 \text { (Painel Aleatório) }\end{array}$ \\
\hline Diagnosticar endogeneidade & Smith-Blundell & $\begin{array}{l}\text { H0: as variáveis explicativas são exógenas a } \\
\text { qualquer nível de significância. } \\
\text { H1: as variáveis explicativas não são } \\
\text { exógenas a qualquer nível de significância. }\end{array}$ \\
\hline $\begin{array}{l}\text { Diagnosticar a normalidade } \\
\text { dos resíduos }\end{array}$ & Jarque-Bera & $\begin{array}{l}\text { H0: o erro do modelo de regressão possui } \\
\text { distribuição normal } \\
\text { H1: o erro do modelo de regressão possui } \\
\text { distribuição não-normal }\end{array}$ \\
\hline $\begin{array}{c}\text { Diagnosticar a } \\
\text { homocedasticidade }\end{array}$ & White & $\begin{array}{l}\text { H0: a variância dos erros é constante. } \\
\text { H1: a variância dos erros não é constante. }\end{array}$ \\
\hline
\end{tabular}

Fonte: Adaptado de Greene (1997).

Legenda: ${ }^{\text {a }}$ Caso seja detectada heterocedasticidade recomenda-se o uso de estimador semiparamétrico de Powell: estimator Least Absolute Deviation (LAD). Esse estimador considera apenas que a mediana é zero.

Para o cálculo da regressão tobit em painel foram utilizados os aplicativos: Gretl e Stata versão 13.

\subsubsection{Modelo de programação matemática - Data Envelopment Analysis - DEA}

Os outputs no setor público são intangíveis em muitos aspectos, tornando-se difícil definir uma função de oferta no sentido convencional. Dessa forma as organizações do setor público produzem bens que estão livres no ponto de uso (não excludentes) o que implica que os preços das saídas não são determinados pelas forças de mercado. Como a eficiência econômica não pode ser medida diretamente, uma técnica é necessária para produção de uma fronteira de eficiência que permitirá o benchmarking relativamente preciso (SUTHERLAND; PRICE; JOUMARD; NICQ, 2006).

O marco inicial para a discussão de fronteiras e medidas de eficiência é o trabalho de Farrell (1957), posteriormente generalizado por Charnes, Cooper e Rhodes (1978), que estenderam o modelo para múltiplos recursos e resultados na obtenção de um indicador que atendesse ao conceito de eficiência de Koopmans $(1951)^{35}$. A partir de então, a técnica de construção de fronteiras de eficiência tem sido bastante difundida, tornando-se conhecida (no seu ramo não-paramétrico) como Data Envelopment Analysis (DEA).

\footnotetext{
${ }^{35}$ Eficiência no sentido de Pareto-Koopmans existe quando um plano de operação satisfaz as seguintes condições: 1) um produto não pode ser gerado em maior quantidade sem que seja diminuída a quantidade gerada de algum outro produto ou sem que seja aumentada a quantidade consumida de pelo menos um insumo; 2) um insumo não pode ser consumido em menor quantidade sem que seja aumentada a quantidade consumida de algum outro insumo ou sem que seja diminuída a geração de pelo menos um produto (SUTHERLAND; PRICE; JOUMARD; NICQ, 2006).
} 
Em DEA o objeto sob estudo é denominado DMU - Decision Making Unit. Essas DMU são avaliadas segundo a relação: $\frac{\text { Input }}{\text { Output }}$. A Figura 6 ilustra a relação básica entre os inputs e outputs.

Figura 6 - Função de produção

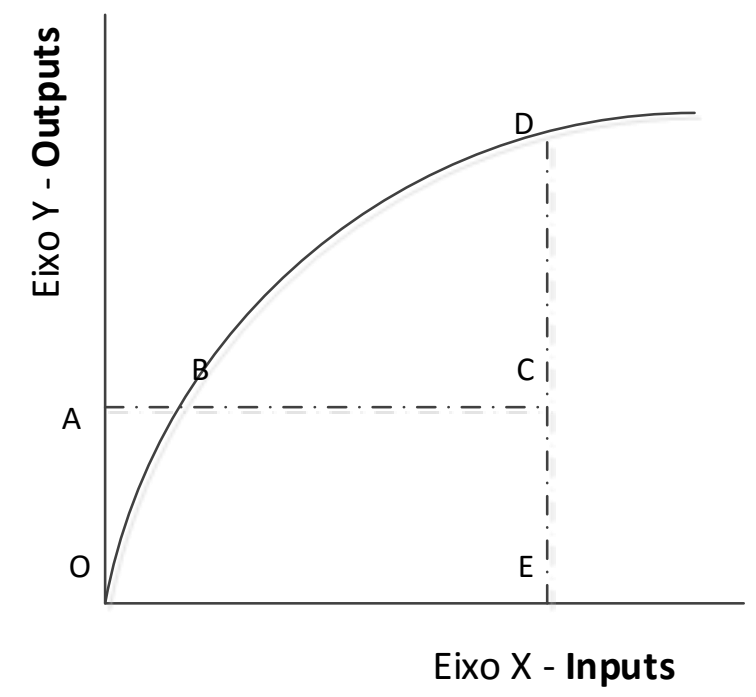

Fonte: Elaborado pelo autor

Considerando a Figura 6, tome-se como exemplo uma função de produção, em que $\mathrm{x}$ representa um input e y representa um output. A máxima quantidade de produto que a utilização de $\mathrm{x}$ pode gerar é representada por $\mathrm{f}(\mathrm{x})$, ou seja, a função de produção. Nota-se que o ponto $\mathrm{C}$, situado abaixo da fronteira, indica uma região factível de produção. No entanto, esse ponto significa que se está empregando OE unidades de x para produzir OA unidades de y. Ao operar abaixo da fronteira, esse plano de produção é considerado ineficiente, pois, dada a tecnologia disponível, não se emprega da melhor forma os recursos. Por outro lado, o ponto B é dito eficiente, já que produz a mesma quantidade de output utilizando a menor quantidade de input possível. O ponto D também representa um plano de produção tecnicamente viável e eficiente, com o qual se obtém o máximo de output, utilizando a mesma quantidade de input. 
De modo semelhante, a Figura 6 pode representar a fronteira de serviços, que representa a melhor oferta disponível para determinado nível de necessidades. A construção dessa fronteira parte da ideia de que a mesma oferta de serviços deve estar disponibilizada para necessidades semelhantes, atendendo ao princípio distributivo da equidade. Estar situado abaixo da fronteira significa déficit relativo dos serviços em questão.

A DEA possui algumas limitações. Em primeiro lugar, as estimativas não paramétricas de eficiência são particularmente sensíveis ao erro de medição, ruído estatístico e valores discrepantes. Uma observação que determina um segmento da fronteira de eficiência erroneamente, por sua vez afeta a medida de ineficiência para todas as escolas ou países que se encontram no segmento. Em segundo lugar, pequenas amostras, sendo este problema agravado quando o número de entradas e saídas se torna elevado. Em terceiro lugar, inputs ou outputs omitidos ou irrelevantes afetam as estimativas de ineficiência. Neste caso, as variáveis omitidas tendem a levar a estimativas de ineficiência que são maiores do que a verdadeira ineficiência, enquanto as variáveis irrelevantes resultarão em estimativas de ineficiência que são muito pequenas (COOPER; SEIFORD; TONE, 2007).

A mensuração da DEA pode ser avaliada considerando determinados parâmetros conforme consta no Quadro 17.

Quadro 17 - Parâmetros para avaliar a eficiência por DEA

\begin{tabular}{|c|l|}
\hline Parâmetro & \multicolumn{1}{c|}{ Alternativas } \\
\hline Multiplicidade de inputs e outputs & $\begin{array}{l}\text { Um input e um output, um input e mais de um output, mais de } \\
\text { um input e um output, mais de um input e mais de um output. }\end{array}$ \\
\hline Elemento a ser maximizado & $\begin{array}{l}\text { Eficiência dos inputs (envoltória inferior) e eficiência dos } \\
\text { outputs (envoltória superior) }\end{array}$ \\
\hline $\begin{array}{c}\text { Tipo de input quanto às } \\
\text { características financeiras }\end{array}$ & Eficiência técnica e eficiência alocativa/ custos \\
\hline $\begin{array}{c}\text { Tipo de inputs e outputs quanto ao } \\
\text { controle do tomador de decisão }\end{array}$ & Discricionários e não discricionários (ambientais) \\
\hline Ponderação na relação & $\begin{array}{l}\text { Com ou sem relação de pesos entres os inputs apenas, entres } \\
\text { os outputs apenas e entre inputs e outputs. }\end{array}$ \\
\hline
\end{tabular}

Fonte: Adaptado de Sutherland, Price, Joumard e Nicq (2006), Cooper, Seiford e Tone (2007), Schwellnus (2009).

No caso de múltiplos inputs ou outputs, as medidas de eficiência são determinadas de forma semelhante, mantendo as proporções relativas de inputs ou outputs constantes para medir a distância até a fronteira (SUTHERLAND; PRICE; JOUMARD; NICQ, 2006; COOPER; SEIFORD; TONE, 2007; SCHWELLNUS, 2009). 
Caso sejam mantidos os inputs constantes, estará se buscando a eficiência dos outputs: envoltória superior. Caso sejam mantidos os outputs constantes, estará se buscando a eficiência dos inputs: envoltória inferior (SUTHERLAND; PRICE; JOUMARD; NICQ, 2006; COOPER; SEIFORD; TONE, 2007; SCHWELLNUS, 2009).

Quanto ao tipo de input, quando se considera a relação entre um input quantificado monetariamente e um outro output de qualquer natureza está de utilizando a eficiência de custos ou alocativa; enquanto nos casos em que o input é de natureza física ou não quantificado monetariamente estará se utilizando a eficiência técnica (SCHWELLNUS, 2009).

A principal dificuldade no plano dos inputs é identificar inputs que não estão sob o controle de provedores de serviços públicos. Por exemplo, no âmbito dos serviços educacionais existem dois tipos principais de inputs para determinar os resultados educacionais: (i) o primeiro tipo abrange fatores discricionários sob o controle do sistema de ensino, como o número de professores, razão professor/aluno, tempo de aula, a qualidade dos professores; (ii) o segundo abrange os chamados insumos nãodiscricionários ou ambientais: origem socioeconômica do aluno, origem do aluno (SUTHERLAND; PRICE; JOUMARD; NICQ, 2006).

No plano dos outputs, a complexidade conceitual é maior. Por exemplo, no âmbito de serviços educacionais, eles poderiam ser restritivos: em termos de horas de escolaridade ou diplomas; ou abrangentes: incrementos para o bem-estar econômico ou PIB (SUTHERLAND; PRICE; JOUMARD; NICQ, 2006).

Quanto ao parâmetro da ponderação, quando se sabe da existência de uma relação funcional já existente ou desejada entre os inputs e outputs, pode-se estabelecer pesos. Um exemplo seria a aplicação da DEA na área da saúde: poderia se estabelecer que para dez mil habitantes deveria haver vinte e cinco médicos ${ }^{36}, 37$, e para cada médico deve haver 2 enfermeiros. Essa relação que pode perfeitamente ser incorporada na análise impactará na respectiva avaliação da eficiência (COOPER; SEIFORD; TONE, 2007).

A DEA presume uma das hipóteses seguintes na relação entre inputs e outputs quanto aos de retornos de escala: crescente, decrescente, variável ou constante. O Quadro 18 mostra as possiblidades (COOPER; SEIFORD; TONE, 2007).

\footnotetext{
${ }^{36}$ Em 1972 ocorreu a III Reunião Especial de Ministros de Saúde das Américas, que resultou no Plano Decenal de Saúde para as Américas. Os ministros ali reunidos estabeleceram a meta de alcançar "8 médicos, 2 odontólogos, 4,5 enfermeiros e 14,5 auxiliares de enfermaria para cada 10.000 habitantes"

${ }^{37}$ No Brasil, o Ministério da saúde recomenda, 2,5 médicos a cada 1000 habitantes, ou seja, 25 médicos a cada 10.000..
} 
Quadro 18 - Fronteiras da DEA quanto às propriedades de escala

\begin{tabular}{|c|l|}
\hline Fronteiras & \multicolumn{1}{c|}{ Descrição } \\
\hline $\begin{array}{c}\text { Retorno constante de escala } \\
\text { (CRS) }\end{array}$ & $\begin{array}{l}\text { Inicialmente conhecido como modelo CCR (Charles-Cooper-Rodes). } \\
\text { Caso ocorra uma expansão/contração, em todos os inputs por um fator, } \\
\text { os outputs podem ser expandidos/ contraídos por este mesmo fator. }\end{array}$ \\
\hline $\begin{array}{c}\text { Retorno não crescente de } \\
\text { escala (NIRS) }\end{array}$ & $\begin{array}{l}\text { Caso ocorra a multiplicação todos os insumos por um fator } \lambda>1, \text { os } \\
\text { produtos são multiplicados por um fator } \lambda^{\prime}<\lambda .\end{array}$ \\
\hline $\begin{array}{c}\text { Retorno não decrescente de } \\
\text { escala (NDRS) }\end{array}$ & $\begin{array}{l}\text { Caso ocorra a multiplicação todos os insumos por um fator } \lambda>1, \text { os } \\
\text { produtos são multiplicados por um fator } \lambda^{\prime} \geq \lambda .\end{array}$ \\
\hline $\begin{array}{c}\text { Retorno variável de escala } \\
\text { (VRS) }\end{array}$ & $\begin{array}{l}\text { Quando os inputs são multiplicados por um fator } \lambda \text {, os outputs podem } \\
\text { seguir qualquer comportamento em relação a este fator } \lambda .\end{array}$ \\
\hline
\end{tabular}

Fonte: Adaptado de Cooper, Seiford e Tone (2007).

Um resultado interessante que pode ser obtido a partir da comparação das propriedades entre os modelos VRS e CRS é a averiguação da ineficiência devido à escala de produção. É possível mostrar que o índice relativo de eficiência obtido pelo modelo CRS será sempre menor ou igual ao obtido pelo modelo VRS (MENDES, 2006). Ou seja, o modelo CCR é mais conservador que o VRS.

Com isso, a razão entre os dois índices mostrará a proporção da ineficiência oriunda da escala de produção da unidade. Esta análise permite, por um lado, que se diferencie o quanto de ineficiência de uma unidade se deve ao tamanho da unidade e o quanto se deve a problemas de gestão. Por outro lado, permite que se façam inferências sobre o tamanho ótimo das unidades (MENDES, 2006). Por fim, A Figura 7 ilustra a relação entre as quatro fronteiras.

Figura 7 - Fronteiras CRS, NIRS, NDRS e VRS e as regiões de retornos à escala

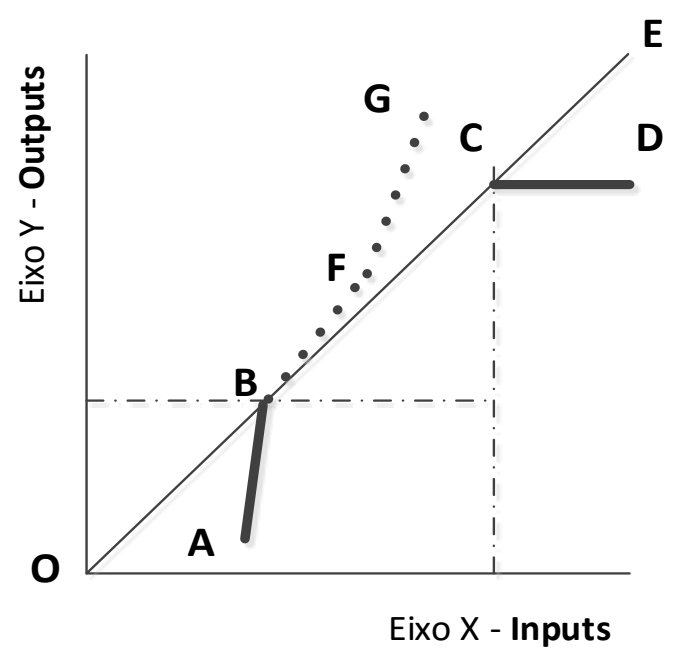

Fonte: Adaptado de Cooper, Seiford e Tone (2007).

Legenda: Segmento OBCE: CRS - Retorno constante de escala; Segmento OBCD: Retorno não crescente de escala; Segmento OBFG: NDRS - Retorno não decrescente de escala; Segmento ABCD: VRS - Retorno variável de escala (VRS). 
Na Figura 7 estão representadas as seguintes fronteiras de produção: a reta OBCE define a fronteira CRS que exibe retornos constantes à escala; os segmentos $\mathrm{OBC}$ e CD definem a fronteira NIRS que exibe retornos não crescentes à escala; os segmentos OB, BF e FG definem a fronteira NDRS que exibe retornos não decrescentes à escala; a fronteira definida pelos segmentos $\mathrm{AB}, \mathrm{BC}$ e $\mathrm{CD}$ definem a fronteira VRS que exibe retornos variáveis à escala, isto é, retornos crescentes à escala, retornos constantes, retornos decrescentes à escala.

Vale ressaltar algumas vantagens da DEA para os fins propostos neste trabalho: (i) dá flexibilidade para trabalhar com múltiplos inputs e outputs; (ii) permite focar em observações individuais em contraste com as médias da amostra; (iii) fornece estimativa robusta de eficiência relativa; (iv) é livre de unidades de medida; (v) não impõe forma funcional à fronteira; (vi) a ponderação das variáveis não sofre qualquer influência exógena no processo de estimação.

Para o cálculo dos escores de (benchmarkings) de eficiência foi utilizado o aplicativo: DEA-Solver versão 8.0 fornecido na obra "Introduction to Data Envelopment Analysis and Its Uses” de autoria de COOPER, SEIFORD e TONE (2007).

\subsubsection{Tobit na segunda fase do DEA}

A análise de eficiência é usualmente feita em dois estágios. No estágio 1 é utilizado o modelo não-paramétrico DEA para calcular a eficiência pela qual o resultado é produzido a partir de insumos físicos e econômicos. No estágio 2 utiliza-se a análise de regressão para relacionar os escores de eficiência a fatores que podem influenciá-la. A escolha da técnica de regressão deve levar em consideração as características da variáveis que constituem a forma funcional $\mathrm{y}=\mathrm{f}(\mathrm{x})$. No caso do DEA, o vetor de eficiência produzido (y) está limitado ao intervalo entre 0 e 1 . Essa característica está fundamentada em estudos de Simar e Wilson (2007; 2011)

Em termos específicos, o modelo de regressão tobit que tem sido utilizado com frequência no segundo estágio do DEA é o tobit de dois limites (2LT - two-limit tobit), com limites em zero e um, permitindo que a variável y transite nesse espaço $(\mathrm{y}=[0,1])$. $\mathrm{O}$ uso dessa abordagem pode ser encontrado em estudos de Chilingerian (1995), Ruggiero e Vitaliano (1999), Bravo-Ureta et alli (2007). 


\subsection{Modelagem funcional e econométrica das hipóteses de pesquisa}

Serão aplicadas três técnicas de análise multivariada de dados: regressão dados em painel mínimos quadrados ordinários (MQO) com efeitos aleatórios, regressão tobit em painel e análise envoltória de dados (DEA), dentro de cinco eixos de análise constantes no Quadro 19.

Quadro 19 - Eixos da pesquisa, hipóteses e técnicas quantitativas

\begin{tabular}{|c|c|c|c|}
\hline \multicolumn{2}{|r|}{ Eixos de análise } & Hipóteses ajustadas ao objeto & Técnicas \\
\hline 1 & $\begin{array}{l}\text { Avaliação da função orçamentária alocativa } \\
\text { sobre desigualdades: efeitos das despesas } \\
\text { com saúde e educação sobre os indicadores } \\
\text { de desigualdade. }\end{array}$ & $\begin{array}{l}\text { Os estados com maior proporção } \\
\text { de despesas nas áreas de educação } \\
\text { e saúde reduziram a desigualdade } \\
\text { de renda, coeteris paribus }\end{array}$ & \multirow{3}{*}{$\begin{array}{l}\text { Regressão } \\
\text { painel MQO } \\
\text { com efeitos } \\
\text { aleatórios e } \\
\text { regressão } \\
\text { painel tobit. }\end{array}$} \\
\hline 2 & $\begin{array}{l}\text { Avaliação da função orçamentária } \\
\text { distributiva sobre as desigualdades: efeitos } \\
\text { dos impostos progressivos sobre os } \\
\text { indicadores de desigualdade. }\end{array}$ & $\begin{array}{l}\text { Os estados com maior proporção } \\
\text { de impostos progressivos } \\
\text { reduziram a desigualdade de } \\
\text { renda, coeteris paribus. }\end{array}$ & \\
\hline 3 & $\begin{array}{l}\text { Avaliação da função orçamentária } \\
\text { distributiva sobre desigualdades: efeitos das } \\
\text { transferências de renda diretas sobre os } \\
\text { indicadores de desigualdade. }\end{array}$ & $\begin{array}{l}\text { Os entes com maior proporção de } \\
\text { transferências de renda direta } \\
\text { reduziram a desigualdade de } \\
\text { renda, coeteris paribus. }\end{array}$ & \\
\hline \multirow{2}{*}{4} & \multirow{2}{*}{$\begin{array}{l}\text { Avaliação da eficiência orçamentária da } \\
\text { função alocativa sobre as desigualdades: } \\
\text { eficiência na educação e no ensino. }\end{array}$} & $\begin{array}{l}\text { As Os estados mais eficientes na } \\
\text { alocação de recursos financeiros } \\
\text { para geração de produtos e } \\
\text { serviços nas áreas de educação e } \\
\text { saúde reduziram a desigualdade } \\
\text { de renda, coeteris paribus. }\end{array}$ & \multirow{3}{*}{$\begin{array}{c}1^{\text {a }} \text { Estágio - } \\
\text { DEA; } 2^{\circ} \\
\text { Estágio - } \\
\text { Regressão } \\
\text { painel MQO } \\
\text { com efeitos } \\
\text { aleatórios e } \\
\text { regressão } \\
\text { painel tobit. }\end{array}$} \\
\hline & & $\begin{array}{l}\text { Os estados mais eficientes na } \\
\text { oferta de produtos ou serviços } \\
\text { para geração de resultados nas } \\
\text { áreas de educação e saúde } \\
\text { reduziram a desigualdade de } \\
\text { renda, coeteris paribus. }\end{array}$ & \\
\hline 5 & $\begin{array}{l}\text { Avaliação da eficiência da função } \\
\text { distributiva sobre as desigualdades: } \\
\text { eficiência arrecadação dos impostos } \\
\text { progressivos }\end{array}$ & $\begin{array}{lrr}\text { Os estados } & \text { mais eficientes na } \\
\text { arrecadação } & \text { dos impostos } \\
\text { progressivos } & \text { reduziram a } \\
\text { desigualdade } & \text { de renda, coeteris } \\
\text { paribus. } & & \end{array}$ & \\
\hline
\end{tabular}

Fonte: Elaborado pelo autor

A seguir serão apresentados dentro de cada eixo as relações funcionais e os modelos econométricos dentro de cada eixo e de cada hipótese considerando as variáveis independentes e dependentes respectivamente. 


\subsubsection{Modelo Econométrico Geral}

O estudo de Lundberg e Squire (2003), utiliza a equação 14 como referência.

Gini $_{i t}=\alpha+S^{\prime}{ }_{i t} \varpi+Z^{\prime}{ }_{i t} \psi+e_{i t}$

Em que a desigualdade representada pelo Coeficiente de uma região ou país "i" em um período " $\mathrm{t}$ " é uma função de variáveis relacionadas ao vetor do crescimento das desigualdades relacionadas ao crescimento econômico $\left(S_{i t}\right)$ e do vetor de variáveis relacionadas ao vetor das desigualdades sem relação com o crescimento econômico $\left(Z_{i t}\right)$.

Considerando que este estudo não busca analisar os efeitos do crescimento econômico, será considerado apenas o vetor $\left(Z_{i t}\right)$.

\subsubsection{Modelos do Eixo 1 - Hipótese 1}

Para se testar a hipótese 1: os estados com maior proporção de despesas nas áreas de educação e saúde reduziram a desigualdade de renda, coeteris paribus ajustou-se o modelo constante na equação 14 . A equação 15 contém a relação funcional da hipótese 1, enquanto a equação 16 contém o respectivo modelo econométrico.

$$
D E S_{i, t, j}=f\left(\frac{D E D U_{i, t, s}}{P I B_{i, t}} ; \frac{D S A U_{i, t, s}}{P I B_{i, t}}\right)
$$

Em que desigualdade (representada pelo índice de Gini, índice de Theil-T, proporção entre $10 \%$ mais ricos e os $40 \%$ mais pobres, proporção entre os $20 \%$ mais ricos e os $20 \%$ mais pobres) é uma função inversa da proporção dos recursos alocados em despesas em educação e saúde.

Utilizou-se o PIB no denominador a exemplo dos estudos mencionados no Quadro 8. Com essa medida, não foi necessário aplicar a deflação, pois tanto o numerador quanto denominador foram obtidos pelos valores nominais.

$$
\begin{gathered}
D E S_{i, t, j}=\beta_{0}+\beta_{1} \frac{D E D U}{P I B}_{i, t, s}+\beta_{2} \frac{D S A U}{P I B}_{i, t, s}+\beta_{3} R N E_{1}(1)+\beta_{4} R C O_{2}(1) \\
+\beta_{5} R S E_{3}(1)+\beta_{6} R S U_{4}(1)+\beta_{7} \frac{R O Y P}{P I B}_{i, t}+\beta_{8} \frac{R O Y S E}{P I B}_{i, t}+\varepsilon_{i, t}
\end{gathered}
$$


Em que o índice DES, desigualdade de renda, de determinada unidade da federação "i” é uma função das despesas percentuais em educação, saúde deste Estado em determinado período “t”. O subscrito “ $\mathrm{j}$ ” identifica as variáveis distintas de desigualdade: Coeficiente de Gini, Coeficiente de Theil-T, Relação entre os 10\% mais ricos e os $40 \%$ mais pobres, Relação entre os $20 \%$ mais ricos e os $20 \%$ mais pobres. O subscrito "s" identifica se os gastos em análise são: estaduais apenas, municipais apenas, ou estaduais e municipais consolidados.

A variável dummie "RNE" identifica os estados da região Nordeste, a variável dummie "RCO" os estados da região Centro-Oeste, a variável dummie "RSE" os estados da região Sudeste, a variável dummie "RSU” os estados da região Sul.

A variável "ROYP" contém os valores recebidos de royalties do petróleo pelos Estados e Municípios e a variável "ROYSE" contém os valores recebidos de royalties do setor elétrico pelos Estados e Municípios. Essa última variável foi incluída, pois nos estudos de Sousa, Cribari-Neto e Stosic (2005) e Postali e Rocha (2009) concluíram que os municípios que recebem receitas de Royalties tenderiam ser menos eficientes no esforço fiscal de arrecadação.

Ressalta-se que o modelo econométrico será testado sob quatro perspectivas diferentes devido a composição da variável dependente desigualdade: índice de Gini, índice de Theil-T, proporção entre $10 \%$ mais ricos e os $40 \%$ mais pobres, proporção entre os $20 \%$ mais ricos e os $20 \%$ mais pobres.

O Quadro 20 contém o detalhamento das variáveis com os respectivos sinais esperados das variáveis relacionadas às hipóteses 1 . 
Quadro 20 - Descrição e sinal esperado das variáveis na hipótese 1

\begin{tabular}{|c|c|c|c|}
\hline Variável & Descrição & $\begin{array}{c}\text { Efeito a ser } \\
\text { observado }\end{array}$ & Sinal \\
\hline Gini $^{\text {a }}$ & $\begin{array}{l}\text { Variável dependente representada pelo } \\
\text { índice Gini do Estado no período i (de } \\
1995 \text { a 2012). O índice varia entre um } \\
\text { número entre } 0 \text { e } 1 \text {, onde } 0 \text { corresponde à } \\
\text { completa igualdade de renda e } 1 \\
\text { corresponde à completa desigualdade } \\
\text { de renda. }\end{array}$ & \multirow{4}{*}{$\begin{array}{l}\text { Desigualdade de } \\
\text { renda }\end{array}$} & \multirow{4}{*}{$\begin{array}{c}\text { Variável } \\
\text { Dependente }\end{array}$} \\
\hline Theil-T ${ }^{\mathrm{a}}$ & $\begin{array}{l}\text { O índice de Theil-T é dado pelo logaritmo } \\
\text { neperiano da razão entre as médias } \\
\text { aritméticas e geométricas da renda } \\
\text { familiar per capita média. Se a razão entre } \\
\text { as médias for igual a 1, Theil-T será igual } \\
\text { a zero, indicando perfeita distribuição. }\end{array}$ & & \\
\hline $\mathrm{P} 10 / 40^{\mathrm{b}}$ & $\begin{array}{l}\text { Razão de Palma: a razão entre a fatia dos } \\
10 \% \text { mais ricos e a dos } 40 \% \text { mais pobres. } \\
\text { Quanto menor, menor a desigualdade. }\end{array}$ & & \\
\hline $\mathrm{P} 20 / 20^{\mathrm{b}}$ & $\begin{array}{l}\text { Razão entre a fatia dos } 20 \% \text { mais ricos e } \\
\text { a dos } 20 \% \text { mais pobres. Quanto menor, } \\
\text { menor a desigualdade. }\end{array}$ & & \\
\hline DSAU/PIB & $\begin{array}{l}\text { Variável independente representada pelos } \\
\text { recursos oriundos de todas as esferas } \\
\text { alocados na área de saúde } \\
\text { proporcionalmente ao PIB estadual de } \\
\text { determinado Estado. }\end{array}$ & \multirow{2}{*}{$\begin{array}{l}\text { Efeitos da função } \\
\text { orçamentária } \\
\text { alocativa dos gastos } \\
\text { sobre a } \\
\text { desigualdade de } \\
\text { renda }\end{array}$} & $(-)$ \\
\hline DEDU/PIB & $\begin{array}{l}\text { Variável independente representada pelos } \\
\text { recursos oriundos de todas as esferas } \\
\text { alocados na área de educação } \\
\text { proporcionalmente ao PIB estadual de } \\
\text { determinado Estado. }\end{array}$ & & $(-)$ \\
\hline $\begin{array}{l}\text { RNE, RCO, } \\
\text { RSE, RSU }\end{array}$ & $\begin{array}{l}\text { Variável Dummie policotômica que } \\
\text { representa as cinco regiões } \\
\text { administrativas: Norte, Nordeste, Centro- } \\
\text { Oeste, Sudeste e Sul. A região referência } \\
\text { foi a região Norte. }\end{array}$ & $\begin{array}{c}\text { Diferenças entre as } \\
\text { regiões. }\end{array}$ & $\begin{array}{l}\text { A tendência é que } \\
\text { as regiões Sul e } \\
\text { Sudeste tenham } \\
\text { sinal (-) em relação } \\
\text { a região Norte. }\end{array}$ \\
\hline ROYP/PIB & $\begin{array}{l}\text { Variável independente representada pelos } \\
\text { recursos recebidos de royalties do } \\
\text { petróleo proporcionalmente ao PIB } \\
\text { estadual. }\end{array}$ & \multirow{2}{*}{$\begin{array}{l}\text { Efeitos dos recursos } \\
\text { dos royalties sobre a } \\
\text { desigualdade de } \\
\text { renda }\end{array}$} & $(-)$ \\
\hline ROYSE/PIB & $\begin{array}{l}\text { Variável independente representada pelos } \\
\text { recursos recebidos de royalties do setor } \\
\text { elétrico proporcionalmente ao PIB } \\
\text { estadual. }\end{array}$ & & $(-)$ \\
\hline
\end{tabular}

Fonte: Elaborado pelo autor

\subsubsection{Modelos do Eixo 2 - Hipótese 2}

Considerando-se a hipótese 2: os estados com maior proporção de impostos progressivos reduziram a desigualdade de renda, coeteris paribus foi estipulado o seguinte modelo funcional na equação 17 e os modelos econométricos nas equações 18 , 19,20 e 21. 
$D E S_{i, t, j}=f\left(\frac{I M P O S T O S \_P R O G R E S S I V O S}{P I B_{i, t}}\right)$

Em que desigualdade é uma função inversa da proporção dos impostos progressivos que por sua natureza incidem com maior impacto sobre a população de maior renda ou riqueza. Utilizou-se o PIB no denominador a exemplo dos estudos mencionados no Quadro 8. Com essa medida, não foi necessário aplicar a deflação, pois tanto o numerador quanto denominador foram obtidos pelos valores nominais.

$$
\begin{aligned}
D E S_{i, t, j} & =\beta_{0}+\beta_{1} \frac{I P T U}{P I B}_{i, t, s}+\beta_{2} \frac{I T B I}{P I B}_{i, t, s}+\beta_{3} R N E_{1}(1)+\beta_{4} R C O_{2}(1) \\
& +\beta_{5} R S E_{3}(1)+\beta_{6} R S U_{4}(1)+\beta_{7} \frac{R O Y P}{P I B}_{i, t}+\beta_{8} \frac{R O Y S E}{P I B}_{i, t}+\varepsilon_{i, t}
\end{aligned}
$$

Em que o índice DES, desigualdade de renda, de determinada unidade da federação "i”" é uma função do IPTU e do ITBI arrecadados sobre a população desta unidade da federação em determinado período " $\mathrm{t}$ ”. O subscrito “ $\mathrm{j}$ ” identifica as variáveis distintas de desigualdade: Coeficiente de Gini, Coeficiente de Theil-T, Relação entre os $10 \%$ mais ricos e os $40 \%$ mais pobres, Relação entre os $20 \%$ mais ricos e os $20 \%$ mais pobres. A variável dummie "RNE" identifica os estados da região Nordeste, a variável dummie "RCO" os estados da região Centro-Oeste, a variável dummie "RSE" os estados da região Sudeste, a variável dummie "RSU" os estados da região Sul.

A variável "ROYP" contém os valores recebidos de royalties do petróleo pelos Estados e Municípios e a variável "ROYSE" contém os valores recebidos de royalties do setor elétrico pelos Estados e Municípios.

$$
\begin{gathered}
D E S_{i, t, j}=\beta_{0}+\beta_{1} \frac{I P V A}{P I B}_{i, t, s}+\beta_{2} \frac{I T C M D}{P I B}_{i, t, s}+\beta_{3} R N E_{1}(1)+\beta_{4} R C O_{2}(1) \\
+\beta_{5} R S E_{3}(1)+\beta_{6} R S U_{4}(1)+\beta_{7} \frac{R O Y P}{P I B}_{i, t}+\beta_{8} \frac{R O Y S E}{P I B}_{i, t}+\varepsilon_{i, t}
\end{gathered}
$$

Em que o índice DES, desigualdade de renda, de determinada unidade da federação "i” é uma função do IPVA e do ITCMD arrecadados sobre a população desta unidade da federação em determinado período " $t$ ”. As demais variáveis foram descritas na equação 18. 


$$
\begin{aligned}
D E S_{i, t, j} & =\beta_{0}+\beta_{1} \frac{I R}{P I B}_{i, t, s}+\beta_{2} \frac{I T R}{P I B}_{i, t, s}+\beta_{3} R N E_{1}(1)+\beta_{4} R C O_{2}(1) \\
& +\beta_{5} R S E_{3}(1)+\beta_{6} R S U_{4}(1)+\beta_{7} \frac{R O Y P}{P I B}_{i, t}+\beta_{8} \frac{R O Y S E}{P I B}_{i, t}+\varepsilon_{i, t}
\end{aligned}
$$

Em que o índice DES, desigualdade de renda, de determinada unidade da federação "i”" é uma função do IR e do ITR arrecadados sobre a população desta unidade da federação em determinado período " $\mathrm{t}$ ". As demais variáveis foram descritas na equação 18. Por fim, será testado modelo econométrico disposto na equação 21 que considera o efeito simultâneo de todos os impostos objeto de estudo. As variáveis foram descritas nas equações 18,19 e 20.

$$
\begin{aligned}
D E S_{i, t, j} & =\beta_{0}+\beta_{1} \frac{I R}{P I B}_{i, t, s}+\beta_{2} \frac{I T R}{P I B}_{i, t, s}+\beta_{3} \frac{I P V A}{P I B}_{i, t, s}+\beta_{4} \frac{I T C M D}{P I B}_{i, t, s}+\beta_{5} \frac{I P T U}{P I B}_{i, t, s} \\
& +\beta_{6} \frac{I T B I}{P I B}_{i, t, s}+\beta_{7} R N E_{1}(1)+\beta_{8} R C O_{2}(1)+\beta_{9} R N E_{1}(1)+\beta_{10} R C O_{2}(1) \\
& +\beta_{11} R S E_{3}(1)+\beta_{12} R S U_{4}(1)+\beta_{13} \frac{R O Y P}{P I B}_{i, t}+\beta_{14}{\frac{R O Y S E_{i, t}}{P I B}}_{i, t}
\end{aligned}
$$

Por fim, o Quadro 21 mostra os sinais esperados das variáveis relacionadas à hipótese 2. 
Quadro 21 - Descrição e sinal esperado das variáveis na hipótese 2

\begin{tabular}{|c|c|c|c|}
\hline Variável & Descrição & $\begin{array}{c}\text { Efeito a ser } \\
\text { observado }\end{array}$ & Sinal esperado \\
\hline Gini & $\begin{array}{l}\text { Variável dependente representada pelo } \\
\text { índice Gini do Estado no período i (de } \\
1995 \text { a 2012). O índice varia entre um } \\
\text { número entre } 0 \text { e } 1 \text {, onde } 0 \text { corresponde } \\
\text { à completa igualdade de renda e } 1 \\
\text { corresponde à completa desigualdade } \\
\text { de renda. }\end{array}$ & \multirow{4}{*}{$\begin{array}{l}\text { Desigualdade de } \\
\text { renda }\end{array}$} & \multirow{4}{*}{$\begin{array}{c}\text { Variável } \\
\text { Dependente }\end{array}$} \\
\hline Theil-T & $\begin{array}{l}\text { O índice de Theil-T é dado pelo } \\
\text { logaritmo neperiano da razão entre as } \\
\text { médias aritméticas e geométricas da } \\
\text { renda familiar per capita média. Se a } \\
\text { razão entre as médias for igual a } 1 \text {, } \\
\text { Theil-T será igual a zero, indicando } \\
\text { perfeita distribuição. }\end{array}$ & & \\
\hline P10-40 & $\begin{array}{l}\text { Razão de Palma: a razão entre a fatia } \\
\text { dos } 10 \% \text { mais ricos e a dos } 40 \% \text { mais } \\
\text { pobres. Quanto menor, menor a } \\
\text { desigualdade. }\end{array}$ & & \\
\hline P20-20 & $\begin{array}{l}\text { Razão entre a fatia dos } 20 \% \text { mais ricos } \\
\text { e a dos } 20 \% \text { mais pobres. Quanto } \\
\text { menor, menor a desigualdade. }\end{array}$ & & \\
\hline $\begin{array}{c}\text { Impostos } \\
\text { Progressivos/PIB }\end{array}$ & $\begin{array}{l}\text { Variável independente representada } \\
\text { pelos impostos proporcionalmente ao } \\
\text { PIB estadual: IR, ITR, IPVA, ITCMD, } \\
\text { IPTU e ITBI. }\end{array}$ & $\begin{array}{l}\text { Efeitos da função } \\
\text { distributiva sobre } \\
\text { a desigualdade de } \\
\text { renda }\end{array}$ & $(-)$ \\
\hline $\begin{array}{c}\text { RNE, RCO, RSE, } \\
\text { RSU }\end{array}$ & $\begin{array}{l}\text { Variável Dummie policotômica que } \\
\text { representa as cinco regiões } \\
\text { administrativas: Norte, Nordeste, } \\
\text { Centro-Oeste, Sudeste e Sul. A região } \\
\text { referência foi a região Norte. }\end{array}$ & $\begin{array}{l}\text { Diferenças entre } \\
\text { as regiões. }\end{array}$ & $\begin{array}{l}\text { A tendência é que } \\
\text { as regiões Sul e } \\
\text { Sudeste tenham } \\
\text { sinal (-) em } \\
\text { relação a região } \\
\text { Norte. }\end{array}$ \\
\hline ROYP/PIB & $\begin{array}{l}\text { Variável independente representada } \\
\text { pelos recursos recebidos de royalties do } \\
\text { petróleo proporcionalmente ao PIB } \\
\text { estadual. }\end{array}$ & $\begin{array}{l}\text { Efeitos dos } \\
\text { recursos dos }\end{array}$ & $(-)$ \\
\hline ROYSE/PIB & $\begin{array}{l}\text { Variável independente representada } \\
\text { pelos recursos recebidos de royalties do } \\
\text { setor elétrico proporcionalmente ao PIB } \\
\text { estadual. }\end{array}$ & $\begin{array}{l}\text { desigualdade de } \\
\text { renda }\end{array}$ & $(-)$ \\
\hline
\end{tabular}

Fonte: Elaborado pelo autor

Os impostos progressivos tendem a reduzir a desigualdade de renda na medida em

que incidem sobre pessoas com maior renda, ou maior quantidade de propriedade e bens.

Além disso, podem gerar externalidades positivas na medida em que atuam sobre a perspectiva do "limite máximo" constante na Figura 1 deste estudo (COLWEEL, 2011; GIACOMONI, 2012).

O ITBI em que pese não ser progressivo no ordenamento jurídico brasileiro, incide sobre a transferência de propriedade e bens intervivos. Desse modo, se assumirá como premissa que uma maior quantidade desse imposto será paga pelas pessoas com maior quantidade de propriedade e bens. 
Por fim, os entes que recebem receitas de royalties tendem a possuir mais recursos perante os demais entes para alocar em políticas públicas que visem reduzir a desigualdade de renda ${ }^{38}$.

\subsubsection{Modelos do Eixo 3 - Hipótese 3}

Considerando-se a hipótese 3: os entes com maior proporção de transferências de renda direta reduziram a desigualdade de renda, coeteris paribus foi estipulado o seguinte modelo funcional na equação 22 e o modelo econométrico na equação 23.

$D E S_{i, t, j}=f\left(\frac{\text { Transferências_de_renda_diretas }}{P I B_{i, t}}\right)$

Em que o índice de desigualdade de renda (DES) de determinada unidade da federação "i” é uma função da proporção das transferências de renda diretas sobre o Produto Interno Bruto Estadual destinadas à população de determinado ente público "i”" em determinado período “t”. O subscrito “j”” identifica diferentes variáveis para mensurar a desigualdade de renda.

$$
\begin{aligned}
& \text { DES }_{i, t, j}=\beta_{0}+\beta_{1} \frac{\text { BolsaFam }}{P I B}_{i, t}+\beta_{2} \frac{\text { BPCIdo }}{P I B}_{i, t}+\beta_{3} \frac{\text { BPCDef }}{P I B}_{i, t}+\beta_{4} R N E_{1}(1) \\
& +\beta_{5} R C O_{2}(1)+\beta_{6} R S E_{3}(1)+\beta_{7} R S U_{4}(1)+\beta_{8} \frac{R O Y P}{P I B}_{i, t}+\beta_{9} \frac{R O Y S E}{P I B}_{i, t}+\varepsilon_{i, t}
\end{aligned}
$$

Em que o índice DES, desigualdade de renda, de determinada unidade da federação “i” é uma função do Bolsa-Família, do Benefício de Prestação Continuado ao Idoso e do Benefício de Prestação Continuado ao Deficiente destinados à população desta unidade da federação em determinado período “ $t$ ”. O subscrito “ $j$ ” identifica as variáveis distintas de desigualdade: Coeficiente de Gini, Coeficiente de Theil-T, Relação entre os $10 \%$ mais ricos e os $40 \%$ mais pobres, Relação entre os $20 \%$ mais ricos e os $20 \%$ mais pobres. A variável dummie "RNE" identifica os estados da região Nordeste, a variável dummie "RCO" os estados da região Centro-Oeste, a variável dummie "RSE" os estados da região Sudeste, a variável dummie "RSU" os estados da região Sul. A variável "ROYP” contém os valores recebidos de royalties do petróleo pelos Estados e Municípios e a variável "ROYSE" contém os valores recebidos de royalties do setor elétrico pelos Estados e Municípios. O Quadro 22 contém o sinal esperado das variáveis dispostas na equação 23 .

\footnotetext{
${ }^{38}$ No Brasil os Estados do Rio de Janeiro e Espírito Santo concentram 90\% das receitas de royalties destinadas aos estados.
} 
Quadro 22 - Descrição e sinal esperado das variáveis na hipótese 3

\begin{tabular}{|c|c|c|c|}
\hline Variável & Descrição & $\begin{array}{c}\text { Efeito a ser } \\
\text { observado }\end{array}$ & Sinal esperado \\
\hline Gini & $\begin{array}{l}\text { Variável dependente representada pelo } \\
\text { índice Gini do Estado no período i (de } \\
1995 \text { a 2012). O índice varia entre um } \\
\text { número entre } 0 \text { e } 1 \text {, onde } 0 \text { corresponde à } \\
\text { completa igualdade de renda e } 1 \\
\text { corresponde à completa desigualdade } \\
\text { de renda. }\end{array}$ & \multirow{4}{*}{$\begin{array}{l}\text { Desigualdade de } \\
\text { renda }\end{array}$} & \multirow{4}{*}{$\begin{array}{c}\text { Variável } \\
\text { Dependente }\end{array}$} \\
\hline Theil-T & $\begin{array}{l}\text { O índice de Theil-T é dado pelo logaritmo } \\
\text { neperiano da razão entre as médias } \\
\text { aritméticas e geométricas da renda } \\
\text { familiar per capita média. Se a razão entre } \\
\text { as médias for igual a 1, Theil-T será igual } \\
\text { a zero, indicando perfeita distribuição. }\end{array}$ & & \\
\hline P10-40 & $\begin{array}{l}\text { Razão de Palma: a razão entre a fatia dos } \\
10 \% \text { mais ricos e a dos } 40 \% \text { mais pobres. } \\
\text { Quanto menor, menor a desigualdade. }\end{array}$ & & \\
\hline P20-20 & $\begin{array}{l}\text { Razão entre a fatia dos } 20 \% \text { mais ricos e } \\
\text { a dos } 20 \% \text { mais pobres. Quanto menor, } \\
\text { menor a desigualdade. }\end{array}$ & & \\
\hline $\begin{array}{l}\text { Transferências de } \\
\text { Renda Diretas e } \\
\text { Transferências de } \\
\text { Renda Diretas/PIB }\end{array}$ & $\begin{array}{l}\text { Variável independente representada por: } \\
\text { transferências do Bolsa Família, } \\
\text { transferências do benefício de prestação } \\
\text { continuada ao idoso, do benefício de } \\
\text { prestação continuada ao deficiente } \\
\text { proporcionalmente ao PIB estadual. }\end{array}$ & $\begin{array}{l}\text { Efeitos da função } \\
\text { distributiva sobre } \\
\text { a desigualdade de } \\
\text { renda }\end{array}$ & $(-)$ \\
\hline $\begin{array}{c}\text { RNE, RCO, RSE, } \\
\text { RSU }\end{array}$ & $\begin{array}{l}\text { Variável Dummie policotômica que } \\
\text { representa as cinco regiões } \\
\text { administrativas: Norte, Nordeste, Centro- } \\
\text { Oeste, Sudeste e Sul. A região referência } \\
\text { foi a região Norte. }\end{array}$ & $\begin{array}{l}\text { Diferenças entre } \\
\text { as regiões }\end{array}$ & $\begin{array}{l}\text { A tendência é que } \\
\text { as regiões Sul e } \\
\text { Sudeste tenham } \\
\text { sinal (-) em } \\
\text { relação a região } \\
\text { Norte. }\end{array}$ \\
\hline ROYP/PIB & $\begin{array}{l}\text { Variável independente representada pelos } \\
\text { recursos recebidos de royalties do } \\
\text { petróleo proporcionalmente ao PIB } \\
\text { estadual. }\end{array}$ & $\begin{array}{l}\text { Efeitos dos } \\
\text { recursos dos }\end{array}$ & $(-)$ \\
\hline ROYSE/PIB & $\begin{array}{l}\text { Variável independente representada pelos } \\
\text { recursos recebidos de royalties do setor } \\
\text { elétrico proporcionalmente ao PIB } \\
\text { estadual. }\end{array}$ & $\begin{array}{l}\text { royalties sobre a } \\
\text { desigualdade de } \\
\text { renda }\end{array}$ & $(-)$ \\
\hline
\end{tabular}

Fonte: Elaborado pelo autor

\subsubsection{Modelos do Eixo 4 - Hipóteses 4 e 5}

A avaliação do eixo 4 insere a questão da eficiência e contempla duas hipóteses: hipótese 4 - os estados mais eficientes na alocação de recursos financeiros para geração de produtos e serviços nas áreas de educação e saúde reduziram a desigualdade de renda, coeteris paribus; e hipótese 5 - os estados mais eficientes na oferta de produtos ou serviços para geração de resultados nas áreas de educação e saúde reduziram a desigualdade de renda, coeteris paribus. 
Assim, conforme exposto na Figura 5 e no Quadro 18, no primeiro estágio será realizado uma análise envoltória de dados com foco orientada aos outputs: envoltória superior; e no segundo estágio, considerando os resultados obtidos, será feita uma avaliação da relação entre eficiência e a desigualdade de renda. O quadro 23 mostra os inputs e outputs a serem utilizados.

\begin{tabular}{|c|c|c|c|c|}
\hline Hipótese & Área & Inputs & Outputs & Fonte \\
\hline \multirow{2}{*}{$\begin{array}{l}\text { Hipótese } 4 \text { - } \\
\text { Eficiência na } \\
\text { alocação dos } \\
\text { recursos } \\
\text { financeiros }\end{array}$} & Educação & $\begin{array}{l}\text { Gastos } \\
\text { acumulados em } \\
\text { educação no ano }\end{array}$ & $\begin{array}{l}\text {-Número de Professores } \\
\text {-Número de matrículas }\end{array}$ & $\begin{array}{c}\text { Afonso e Aubyn } \\
\text { (2005); Sutherland, } \\
\text { Price, Joumard e Nicq } \\
\text { (2006); Mendes } \\
\text { (2006). }\end{array}$ \\
\hline & Saúde & $\begin{array}{l}\text { Gastos } \\
\text { acumulados em } \\
\text { saúde no ano }\end{array}$ & $\begin{array}{l}\text {-Médicos } \\
\text {-Leitos públicos } \\
\text { disponíveis }\end{array}$ & $\begin{array}{c}\text { Afonso e Aubyn } \\
\text { (2005); Mendes } \\
\text { (2006); Schwellnus } \\
\text { (2009). }\end{array}$ \\
\hline \multirow{2}{*}{$\begin{array}{l}\text { Hipótese } 5 \text { - } \\
\text { Eficiência na } \\
\text { alocação dos } \\
\text { recursos } \\
\text { estruturais }\end{array}$} & Educação & $\begin{array}{l}\text { Professor por } \\
\text { aluno }\end{array}$ & $\begin{array}{l}\text { IDEB: proxy do teste de } \\
\text { PISA - Programme for } \\
\text { International Student } \\
\text { Assessment }\end{array}$ & $\begin{array}{c}\text { Afonso e Aubyn } \\
(2005) \text {; Sutherland, } \\
\text { Price, Joumard e Nicq } \\
\text { (2006) }\end{array}$ \\
\hline & Saúde & $\begin{array}{l}\text {-Médicos por } \\
\text { habitante } \\
\text {-Leitos públicos } \\
\text { disponíveis por } \\
\text { habitante }\end{array}$ & $\begin{array}{l}\text {-Expectativa de vida } \\
\text {-Taxa de sobrevivência }\end{array}$ & $\begin{array}{c}\text { Afonso e Aubyn } \\
\text { (2005); Schwellnus } \\
(2009)\end{array}$ \\
\hline
\end{tabular}

Fonte: Elaborado pelo autor

Considerando que as unidades de observação são os Estados da federação enquanto territórios, o teste de PISA foi descartado, pois contém os resultados apenas por país e a cada triênio ${ }^{39}$. Ao invés do teste de PISA, foi selecionado o IDEB - Índice de Desenvolvimento da Educação Básica.

Após ter se obtido o ranking de eficiência dos estados: (i) Benchmarking de Eficiência na alocação dos recursos financeiros da geração de produtos - BENFIN, no caso da hipótese 4, cujo modelo funcional consta na equação 24; e (ii) Benchmarking de Eficiência na alocação dos recursos estruturais - BENESTRU, no caso da hipótese 5, cujo modelo funcional consta na equação 25, foi realizado o segundo estágio utilizando-se dos modelos econométricos constantes nas equações 26 (hipótese 4) e 27 (hipótese 5).

Desigualdade $_{i, t}=f(B E N F I N)$

\footnotetext{
${ }^{39} \mathrm{http}$ ://portal.inep.gov.br/internacional-novo-pisa-resultados
} 
Em que desigualdade de renda é uma função inversa da eficiência na alocação de recursos financeiros voltados a geração de produtos e serviços de saúde e educação representada pela variável BENFIN. No caso deste estudo, BENFIN foi segregada em duas variáveis BENFIN_SAU e BENFIN_EDU. BENFIN_SAU decorre da aplicação da análise envoltória de dados tendo como input os gastos acumulados em saúde no ano e tendo como outputs médicos e leitos públicos disponíveis; e BENFIN_EDU decorre da aplicação da análise envoltória de dados tendo como input os gastos acumulados em educação no ano e tendo como outcomes número de professores e número de matrículas.

Desigualdade $_{i, t}=f($ BENESTRU $)$

Em que desigualdade de renda é uma função inversa da eficiência na alocação de recursos estruturais voltados ao alcance de resultados nas áreas de saúde e educação representada pela variável BENESTRU. No caso deste estudo, BENESTRU foi segregada em quatro variáveis BENESTRU_SAU; BENESTRU_EF5; BENESTRU_EF9; BENESTRU_EM.

BENESTRU_SAU decorre da aplicação da análise envoltória de dados - DEA tendo como inputs médicos por habitante e leitos públicos disponíveis por habitante e tendo como outcomes expectativa de vida e taxa de sobrevivência.

BENESTRU_EF5 decorre da aplicação da DEA tendo como input professor por aluno na rede pública estadual urbana e rural do $1^{\circ}$ ao $5^{\circ}$ ano do ensino fundamental e tendo como outcome os resultados obtidos no IDEB na rede estadual do $5^{\circ}$ ano do ensino fundamental.

BENESTRU_EF9 decorre da aplicação da DEA tendo como input professor por aluno na rede pública estadual urbana e rural do $6^{\circ}$ ao $9^{\circ}$ ano do ensino fundamental e tendo como outcome os resultados obtidos no IDEB na rede estadual do $9^{\circ}$ ano do ensino fundamental.

BENESTRU_EM decorre da aplicação da DEA tendo como input professor por aluno na rede pública estadual urbana e rural do ensino médio e tendo como outcome os resultados obtidos no IDEB na rede estadual do ensino médio.

$$
\begin{aligned}
& D E S_{i, t, j}=\beta_{0}+\beta_{1} \text { BENFIN }_{-} S A U_{i, t}+\beta_{2} \text { BENFIN_EDU }_{i, t} \beta_{3} R N E_{1}(1)+ \\
& \beta_{4} R C O_{2}(1)+\beta_{5} R S E_{3}(1)+\beta_{6} R S U_{4}(1)+\beta_{7} \frac{R O Y P}{P I B}_{i, t}+\beta_{8} \frac{R O Y S E}{P I B}_{i, t}+\varepsilon_{i, t}
\end{aligned}
$$




$$
\begin{aligned}
\text { DES }_{i, t, j} & =\beta_{0}+\beta_{1} \text { BENESTRU_SAU }_{i, t}+\beta_{2} \text { BENESTRU_EF } 5_{i, t}+ \\
& +\beta_{3} \text { BENESTRU_EF9 }_{i, t}+\beta_{4} B E N E S T R U_{-} E M_{i, t}+\beta_{5} R N E_{1}(1) \\
& +\beta_{6} R C O_{2}(1)+\beta_{7} R S E_{3}(1)+\beta_{8} R S U_{4}(1)+\beta_{9} \frac{R O Y P}{P I B}_{i, t}+\beta_{10} \frac{R O Y S E}{P I B}_{i, t}+\varepsilon_{i, t}
\end{aligned}
$$

O uso do benchmarking obtido da DEA como variável independente ou explicativa não é usual, mas foi utilizado em estudo de Cummins e Xie (2008).

As demais variáveis já foram discriminadas na equação 16. Por fim, o Quadro 24

\begin{tabular}{|c|c|c|c|}
\hline Variável & Descrição & $\begin{array}{c}\text { Efeito a ser } \\
\text { observado }\end{array}$ & Sinal \\
\hline Gini $^{a}$ & $\begin{array}{l}\text { Variável dependente representada pelo índice } \\
\text { Gini do Estado no período i (de } 1995 \text { a 2012). } \\
\text { O índice varia entre um número entre } 0 \text { e } 1 \text {, } \\
\text { onde } 0 \text { corresponde à completa igualdade } \\
\text { de renda e } 1 \text { corresponde à completa } \\
\text { desigualdade de renda. }\end{array}$ & \multirow{4}{*}{$\begin{array}{l}\text { Desigualdade de } \\
\text { renda }\end{array}$} & \multirow{4}{*}{$\begin{array}{c}\text { Variável } \\
\text { Dependente }\end{array}$} \\
\hline Theil-T ${ }^{\mathrm{a}}$ & $\begin{array}{l}\text { O índice de Theil-T é dado pelo logaritmo } \\
\text { neperiano da razão entre as médias aritméticas } \\
\text { e geométricas da renda familiar per capita } \\
\text { média. Se a razão entre as médias for igual a } \\
\text { 1, Theil-T será igual a zero, indicando perfeita } \\
\text { distribuição. }\end{array}$ & & \\
\hline $\mathrm{P} 10 / 40^{\mathrm{b}}$ & $\begin{array}{l}\text { Razão de Palma: a razão entre a fatia dos } 10 \% \\
\text { mais ricos e a dos } 40 \% \text { mais pobres. Quanto } \\
\text { menor, menor a desigualdade. }\end{array}$ & & \\
\hline $\mathrm{P} 20 / 20^{\mathrm{b}}$ & $\begin{array}{l}\text { Razão entre a fatia dos } 20 \% \text { mais ricos e a dos } \\
20 \% \text { mais pobres. Quanto menor, menor a } \\
\text { desigualdade. }\end{array}$ & & \\
\hline BENFIN & $\begin{array}{l}\text { Variável que pode chegar a } 100 \% \text { e } \\
\text { identifica os entes que mantendo os } \\
\text { outputs constantes foram mais eficientes } \\
\text { nos inputs financeiros. }\end{array}$ & $\begin{array}{l}\text { Eficiência nos } \\
\text { inputs financeiros }\end{array}$ & $(-)$ \\
\hline BENESTRU & $\begin{array}{l}\text { Variável que pode chegar a } 100 \% \text { e } \\
\text { identifica os entes que mantendo os } \\
\text { outcomes constantes foram mais } \\
\text { eficientes nos inputs estruturais. }\end{array}$ & $\begin{array}{l}\text { Eficiência nos } \\
\text { inputs físicos }\end{array}$ & $(-)$ \\
\hline $\begin{array}{l}\text { RNE, RCO, } \\
\text { RSE, RSU }\end{array}$ & $\begin{array}{l}\text { Variável Dummie policotômica que } \\
\text { representa as cinco regiões } \\
\text { administrativas: Norte, Nordeste, Centro- } \\
\text { Oeste, Sudeste e Sul. A região referência } \\
\text { foi a região Norte. }\end{array}$ & $\begin{array}{l}\text { Diferenças entre as } \\
\text { regiões. }\end{array}$ & $\begin{array}{l}\text { A tendência é que } \\
\text { as regiões Sul e } \\
\text { Sudeste tenham } \\
\text { sinal (-) em relação } \\
\text { a região Norte. }\end{array}$ \\
\hline ROYP/PIB & $\begin{array}{l}\text { Variável independente representada pelos } \\
\text { recursos recebidos de royalties do } \\
\text { petróleo proporcionalmente ao PIB } \\
\text { estadual. }\end{array}$ & $\begin{array}{l}\text { Efeitos dos } \\
\text { recursos dos }\end{array}$ & $(-)$ \\
\hline ROYSE/PIB & $\begin{array}{l}\text { Variável independente representada pelos } \\
\text { recursos recebidos de royalties do setor } \\
\text { elétrico proporcionalmente ao PIB } \\
\text { estadual. }\end{array}$ & $\begin{array}{l}\text { royalties sobre } \\
\text { desigualdade de } \\
\text { renda }\end{array}$ & $(-)$ \\
\hline
\end{tabular}
mostra os sinais esperados das variáveis relacionadas às hipóteses 4 e 5.

Quadro 24 - Descrição e sinal esperado das variáveis nas hipóteses 4 e 5

Fonte: Elaborado pelo autor 


\subsubsection{Modelos do Eixo 5 - Hipótese 6}

Tal qual o eixo 4 relacionado à função alocativa, o eixo 5 explora a questão da eficiência, porém com enfoque sobre a função distributiva contemplando a seguinte hipótese: Os estados mais eficientes na arrecadação dos impostos progressivos reduziram a desigualdade de renda, coeteris paribus.

Assim, conforme exposto na Figura 5 e no Quadro 19, no primeiro estágio será realizado uma análise envoltória de dados com foco nos outcomes: envoltória superior; e no segundo estágio, considerando os resultados obtidos, será feita uma avaliação da relação entre eficiência e a desigualdade de renda. O quadro 25 mostra os inputs e outputs a serem utilizados.

Quadro 25 - Inputs e Outputs a serem utilizados na hipótese 6 - eficiência na função distributiva

\begin{tabular}{|c|c|c|c|}
\hline Hipótese & Inputs & Outputs & Fonte \\
\hline \multirow{4}{*}{6} & $\begin{array}{c}\text { Quantidade de veículos } \\
\text { automotores }\end{array}$ & $\begin{array}{c}\text { Receita do Imposto sobre Propriedade } \\
\text { de Veículos Automotores - IPVA }\end{array}$ & $\begin{array}{c}\text { Souza Júnior e } \\
\text { Gasparini (2006) }\end{array}$ \\
\cline { 2 - 4 } & \multirow{2}{*}{ Área urbana e rural $^{40}$} & Receita do Imposto Predial Territorial & $\begin{array}{c}\text { Contribuição deste } \\
\text { estudo }\end{array}$ \\
\cline { 3 - 4 } & Receita do Imposto Territorial Rural - & $\begin{array}{c}\text { Contribuição deste } \\
\text { estudo }\end{array}$ \\
\hline
\end{tabular}

Fonte: Elaborado pelo autor

Ressalta-se que na mensuração dos benchmarkings do IPTU e do ITR foram retiradas as terras indígenas ${ }^{41} \mathrm{e}$ as áreas de proteção ambiental ${ }^{42}$, uma vez que são isentas destes impostos.

Após se obter ranking de eficiência das unidades da federação: Benchmarking de Eficiência Arrecadatória de Impostos Progressivos - BENARIP cujo modelo funcional consta na equação 28, foi realizado o segundo estágio utilizando-se o modelo econométrico constante na equação 29.

Desigualdade $_{i, t}=f(B E N A R I P)$

Em que desigualdade de renda é uma função inversa da eficiência na arrecadação de impostos progressivos representada pela variável BENARIP.

\footnotetext{
${ }^{40}$ O IBGE no pedido de acesso a informação número 03950001146201516 formulado em 29/06/2015 no âmbito deste estudo, respondeu que a distinção entre zonas urbana e rural é de competência dos municípios, que o delimitam legalmente através da definição de perímetro urbano. Face a grandiosidade territorial, com 5570 municípios brasileiros, nem sempre o IBGE obtém êxito em extrair as informações. Desta forma, as precisas áreas urbanas e rurais podem ser obtidas somente através das prefeituras, através de seus dispositivos legais de definição de perímetros urbanos.

${ }^{41} \mathrm{http}$ ://www.funai.gov.br/index.php/indios-no-brasil/terras-indigenas

${ }^{42} \mathrm{http} / / /$ www.icmbio.gov.br/portal/unidades-de-conservacao.html
} 
No caso deste estudo, BENARIP foi segregada em duas variáveis BENARIP_Area e BENARIP_Frota. BENARIP_Area decorre da aplicação da análise envoltória de dados tendo como input área útil do território estadual e tendo como outcomes a receita arrecadada do IPTU e a receita arrecadada do ITR; e BENARIP_Frota decorre da aplicação da análise envoltória de dados tendo como input frota de veículos automotores e tendo como outcome a receita arrecadada do IPVA.

$$
\begin{aligned}
\text { DES }_{i, t, j} & =\beta_{0}+\beta_{1} \text { BENARIP_Area }_{i, t}+\beta_{2} \text { BENARIP_Frota }_{i, t}+\beta_{3} \text { RNE }_{1}(1) \\
& +\beta_{4} R C O_{2}(1)+\beta_{5} R_{S E_{3}}(1)+\beta_{6} R S U_{4}(1)+\beta_{7} \frac{\text { ROYP }}{P I B}_{i, t}+\beta_{8} \frac{\text { ROYSE }}{P I B}_{i, t}+\varepsilon_{i, t}
\end{aligned}
$$

As demais variáveis já foram discriminadas na equação 16. Por fim, o Quadro 26 mostra os sinais esperados das variáveis relacionadas à hipótese 6 .

Ressalta-se que o uso do benchmarking obtido da DEA como variável independente ou explicativa não é usual, mas foi utilizado em estudo de Cummins e Xie (2008). 
Quadro 26 - Descrição e sinal esperado das variáveis na hipótese 6

\begin{tabular}{|c|c|c|c|}
\hline Variável & Descrição & $\begin{array}{c}\text { Efeito a ser } \\
\text { observado }\end{array}$ & Sinal \\
\hline Gini $^{a}$ & $\begin{array}{l}\text { Variável dependente representada pelo } \\
\text { índice Gini do Estado no período i (de } 1995 \\
\text { a 2012). O índice varia entre um número } \\
\text { entre } 0 \text { e } 1 \text {, onde } 0 \text { corresponde à completa } \\
\text { igualdade de renda e } 1 \text { corresponde à } \\
\text { completa desigualdade de renda. }\end{array}$ & \multirow{4}{*}{$\begin{array}{l}\text { Desigualdade de } \\
\text { renda }\end{array}$} & \multirow{4}{*}{$\begin{array}{c}\text { Variável } \\
\text { Dependente }\end{array}$} \\
\hline Theil-T ${ }^{a}$ & $\begin{array}{l}\text { O índice de Theil-T é dado pelo logaritmo } \\
\text { neperiano da razão entre as médias } \\
\text { aritméticas e geométricas da renda familiar } \\
\text { per capita média. Se a razão entre as médias } \\
\text { for igual a 1, Theil-T será igual a zero, } \\
\text { indicando perfeita distribuição. }\end{array}$ & & \\
\hline $\mathrm{P} 10 / 40^{\mathrm{b}}$ & $\begin{array}{l}\text { Razão de Palma: a razão entre a fatia dos } \\
10 \% \text { mais ricos e a dos } 40 \% \text { mais pobres. } \\
\text { Quanto menor, menor a desigualdade. }\end{array}$ & & \\
\hline $\mathrm{P} 20 / 20^{\mathrm{b}}$ & $\begin{array}{l}\text { Razão entre a fatia dos } 20 \% \text { mais ricos e a } \\
\text { dos } 20 \% \text { mais pobres. Quanto menor, } \\
\text { menor a desigualdade. }\end{array}$ & & \\
\hline BENIP & $\begin{array}{l}\text { Variável que pode chegar a } 100 \% \text { e } \\
\text { identifica os entes que mantendo os inputs } \\
\text { constantes foram mais eficientes nos } \\
\text { outputs financeiros. }\end{array}$ & $\begin{array}{l}\text { Eficiência dos } \\
\text { inputs físicos } \\
\text { sobre a } \\
\text { desigualdade de } \\
\text { renda }\end{array}$ & $(-)$ \\
\hline $\begin{array}{l}\text { RNE, RCO, } \\
\text { RSE, RSU }\end{array}$ & $\begin{array}{l}\text { Variável Dummie policotômica que } \\
\text { representa as cinco regiões administrativas: } \\
\text { Norte, Nordeste, Centro-Oeste, Sudeste e } \\
\text { Sul. A região referência foi a região Norte. }\end{array}$ & $\begin{array}{l}\text { Diferenças entre as } \\
\text { regiões. }\end{array}$ & $\begin{array}{l}\text { A tendência é que as } \\
\text { regiões Sul e } \\
\text { Sudeste tenham sinal } \\
\text { (-) em relação a } \\
\text { região Norte. }\end{array}$ \\
\hline ROYP/PIB & $\begin{array}{l}\text { Variável independente representada pelos } \\
\text { recursos recebidos de royalties do petróleo } \\
\text { proporcionalmente ao PIB estadual. }\end{array}$ & $\begin{array}{l}\text { Efeitos dos } \\
\text { recursos dos }\end{array}$ & $(-)$ \\
\hline ROYSE/PIB & $\begin{array}{l}\text { Variável independente representada pelos } \\
\text { recursos recebidos de royalties do setor } \\
\text { elétrico proporcionalmente ao PIB } \\
\text { estadual. }\end{array}$ & $\begin{array}{l}\text { royalties sobre a } \\
\text { desigualdade de } \\
\text { renda }\end{array}$ & $(-)$ \\
\hline
\end{tabular}

Fonte: Elaborado pelo autor 


\section{RESULTADOS E ANÁLISES}

Nesta seção serão apresentados os resultados por hipótese de pesquisa considerando as premissas, limitações e modelos constantes da seção 3 - metodologia da análise empírica.

\subsection{Resultados da Hipótese 1}

Na subseção 4.1 os gastos estão por função: saúde e educação, enquanto que na seção 4.2 os gastos estão por subfunção ( $2^{\circ}$ nível da função). A mensuração por subfunção foi necessária a partir de resultado controverso obtido na subseção 4.1.1.

\subsubsection{Gastos por Função da Despesa}

Os resultados serão apresentados considerando dois métodos estatísticos: (i) regressão de dados em painel com efeitos aleatórios e (ii) regressão tobit em painel. Para cada método estão dispostas três tabelas: (i) gastos estaduais, (ii) gastos municipais discriminados por estado, (iii) gastos estaduais e municipais discriminados por estado.

As Tabelas 15, 16 e 17 contêm os resultados dos testes aplicados utilizando-se a regressão de dados em painel com efeitos aleatórios. Observa-se nas três tabelas que quanto maior proporção dos gastos em saúde sobre o PIB maior a tendência de redução da desigualdade de renda, enquanto ocorreu efeito inverso para os gastos com educação. Esse resultado alinha-se com os resultados evidenciados por Jha, Biswal e Biswal (2001), Sywester (2002), Berg e Fink (2008), Zhang (2008) Araújo, Alves e Bessaria (2013) que encontraram relação inversa e significativa entre os gastos com saúde e o coeficiente de desigualdade de renda e resultado inconclusivo para os gastos com educação.

O raciocínio se aplica para a proporção dos royalties do petróleo e do setor elétrico sobre o PIB, em que pese não ter sido evidenciada significância estatística para esta última variável.

O efeito regional foi significativo nas regiões Nordeste e Sul perante a Região Norte. Esses resultados se aplicam aos quatro indicadores de desigualdade de renda selecionados na pesquisa. Tomando por exemplo a Tabela 17, que considera os gastos estaduais e municipais, para cada ponto percentual (1\%) de aumento da desigualdade de renda no coeficiente de Gini na região Norte, a região Nordeste obteve 0,06\% a menos e a região Sul obteve $0,03 \%$ a mais. Considerando as características dos indicadores, o resultado aponta que entre 1995 e 2012 a região Sul conseguiu reduzir a desigualdade mais que a região Norte, e a região Norte conseguiu reduzir a desigualdade mais que a região Nordeste. 
Quanto ao diagnóstico do painel, nas três tabelas, considerando os resultados dos testes de Chow e Breusch-Pagan, conclui-se que o modelo de dados em painel seria mais apropriado ao modelo pooled.

Quanto ao teste de Hausman, tomando por base apenas a Tabela 17, verifica-se que o painel com efeitos aleatórios teria preferência sobre o painel com efeitos fixos, com exceção do modelo que tem como variável dependente: o coeficiente de Theil-T.

Tabela 15 - Resultados da regressão de dados em painel com efeitos aleatórios: gastos estaduais

\begin{tabular}{ccccc}
\hline Variáveis & Gini & Theil-T & P10-40 & P20-20 \\
\hline Constante & $0.593570 * * *$ & $0.716495 * * *$ & $22.4858^{* * *}$ & $25.1988^{* * *}$ \\
\hline DSAU/PIB & $-2.01530^{* * *}$ & $-4.71914 * * *$ & $-217.102^{* * *}$ & $-240.908^{* * *}$ \\
\hline DEDU/PIB & $0.373559^{* * *}$ & $0.960709 * * *$ & $41.1166^{* * *}$ & $44.3960 * * *$ \\
\hline RNE & $0.0221411^{* *}$ & $0.0983967 * * *$ & 2.08781 & 1.33089 \\
\hline RCO & -0.0201028 & -0.0394231 & -2.16890 & -2.97193 \\
\hline RSE & $-0.0256259 * *$ & $-0.0650411^{* *}$ & $-2.71297 *$ & $-3.52581^{*}$ \\
\hline RSU & $-0.0631684^{* * *}$ & $-0.148071 * * *$ & $-6.23603 * * *$ & $-7.00207 * * *$ \\
\hline ROYP/PIB & $-3.17453^{* * *}$ & $-7.99406 * *$ & $-388.909 * * *$ & $-389.770^{* * *}$ \\
\hline ROYSE/PIB & -8.54150 & -22.2092 & $-1193.68 *$ & $-1564.62 * *$ \\
\hline Pooled Simples & Não & Não & Não & Não \\
\hline Efeitos Fixos & Não & Não & Não & Não \\
\hline Efeitos Aleatórios & Sim & Sim & Sim & Sim \\
\hline Breusch-Pagan & $4.31153 \mathrm{e}-082$ & $5.15159 \mathrm{e}-037$ & $3.41385 \mathrm{e}-116$ & $1.36825 \mathrm{e}-114$ \\
\hline Hausman & 0.000178433 & 0.00287126 & 0.000218005 & 0.000335003 \\
\hline Normalidade dos Resíduos & 0.01165 & 0.00000 & 0.00000 & 0.00000 \\
\hline p-valor) & 27 & 27 & 27 & 27 \\
\hline Número de Estados & 486 & 486 & 486 & 486 \\
\hline Número de Observações & & &
\end{tabular}

Fonte: Elaborado pelo autor

Nota: $* * *$ Significativo a $1 \%$; * Significativo a $5 \%$; $*$ Significativo a $10 \%$.

Tabela 16 - Resultados da regressão de dados em painel com efeitos aleatórios: gastos municipais

\begin{tabular}{ccccc}
\hline Variáveis & Gini & Theil-T & P10-40 & P20-20 \\
\hline Constante & $0.574974 * *$ & $0.665996 * * *$ & $20.7393^{* * *}$ & $22.7719^{* * *}$ \\
\hline DSAU/PIB & $-3.45779^{* * *}$ & $-9.26787 * * *$ & $-374.444 * * *$ & $-458.833^{* * *}$ \\
\hline DEDU/PIB & $1.16894 * * *$ & $4.05484^{* * *}$ & $117.555^{* * *}$ & $178.769^{* * *}$ \\
\hline RNE & $0.0608333^{* * *}$ & $0.187428^{* * *}$ & $6.30775^{* * *}$ & $6.01004^{* * *}$ \\
\hline RCO & 0.00782249 & 0.0308069 & 0.687260 & 0.426936 \\
\hline RSE & 0.00603730 & 0.0114553 & 0.643048 & 0.512933 \\
\hline RSU & $-0.0331741^{* *}$ & $-0.0774932^{* *}$ & $-3.08890^{*}$ & -3.30569 \\
\hline ROYP/PIB & -1.73510 & $-5.77846^{*}$ & $-197.587 *$ & -181.759 \\
\hline ROYSE/PIB & -1.04918 & -1.43864 & -371.019 & -591.454 \\
\hline Pooled Simples & Não & Não & Não & Não \\
\hline Efeitos Fixos & Não & Não & Não & Não \\
\hline Efeitos Aleatórios & Sim & Sim & Sim & Sim \\
\hline Breusch-Pagan & $6.15707 \mathrm{e}-083$ & $3.66954 \mathrm{e}-036$ & $6.58466 \mathrm{e}-126$ & $1.00119 \mathrm{e}-124$ \\
\hline Hausman & 0.296805 & 0.00603599 & 0.498546 & 0.663392 \\
\hline $\begin{array}{c}\text { Normalidade dos Resíduos } \\
\text { (p-valor) }\end{array}$ & 0.00002 & 0.00000 & 0.00100 & 0.00000 \\
\hline Número de Estados & 27 & 27 & 27 & 27 \\
\hline Número de Observações & 486 & 486 & 486 & 486 \\
\hline
\end{tabular}

Fonte: Elaborado pelo autor

Nota: $* * *$ Significativo a $1 \%$; **Significativo a $5 \%$; *Significativo a $10 \%$. 
Tabela 17 - Resultados da regressão de dados em painel com efeitos aleatórios: gastos estaduais e municipais

\begin{tabular}{ccccc}
\hline Variáveis & Gini & Theil-T & P10-40 & P20-20 \\
\hline Constante & $0.599073 * * *$ & $\begin{array}{c}0.728414 \\
* * * *\end{array}$ & $\begin{array}{c}23.1950 \\
* * *\end{array}$ & $\begin{array}{c}25.8827 \\
* * *\end{array}$ \\
\hline DSAU/PIB & $-1.50501 * * *$ & $\begin{array}{c}-3.63030 \\
* * *\end{array}$ & $\begin{array}{c}-164.485 \\
* * *\end{array}$ & $\begin{array}{c}-182.727 \\
* * *\end{array}$ \\
\hline DEDU/PIB & $0.269310 * * *$ & $0.771690 * * *$ & $\begin{array}{c}29.4381 \\
* * *\end{array}$ & $33.1327 * * *$ \\
\hline RNE & $0.0380842 * * *$ & $0.135690 * * *$ & $3.77327 * * *$ & $3.22593 *$ \\
\hline RCO & -0.0160096 & -0.0284792 & -1.85139 & -2.57184 \\
\hline RSE & -0.0195076 & -0.0512401 & -2.08308 & -2.76893 \\
\hline RSU & $-0.0593232 * * *$ & $-0.139161 * * *$ & $-5.90756 * * *$ & $-6.59222 * * *$ \\
\hline ROYP/PIB & $-1.95289 *$ & -5.42405 & $-239.786 * *$ & -216.613 \\
\hline ROYSE/PIB & -2.12411 & -7.08393 & -462.503 & -711.963 \\
\hline Pooled Simples & Não & Não & Não & Não \\
\hline Efeitos Fixos & Não & Não & Não & Não \\
\hline Efeitos Aleatórios & Sim & Sim & Sim & Sim \\
\hline Breusch-Pagan & $1.07003 \mathrm{e}-104$ & $1.44781 \mathrm{e}-043$ & $3.62786 \mathrm{e}-157$ & $5.97159 \mathrm{e}-155$ \\
\hline Hausman & 0.102877 & 0.0284825 & 0.179554 & 0.22804 \\
\hline $\begin{array}{c}\text { Normalidade dos Resíduos } \\
\text { (p-valor) }\end{array}$ & 0.00001 & 0.00000 & 0.00000 & 0.00000 \\
\hline Número de Estados & 27 & 27 & 27 & 27 \\
\hline Número de Observações & 486 & 486 & 486 & 486 \\
\hline Fonte: Elaborado pelo aur & & &
\end{tabular}

Fonte: Elaborado pelo autor

Nota: ***Significativo a $1 \% ; * *$ Significativo a $5 \%$; *Significativo a $10 \%$.

Observa-se nas Tabelas 15 a 17 que houve uma elevada concordância quanto aos sinais das variáveis independentes face as variáveis dependentes. A única variável que teve variação de sinal foi a variável dummie RCO.

Na sequência, as Tabelas 18, 19 e 20 contêm os resultados dos testes aplicados utilizando-se regressão tobit em painel.

Tabela 18 - Resultados da regressão tobit em painel: gastos estaduais

\begin{tabular}{ccccc}
\hline Variáveis & Gini & Theil-T & P10-40 & P20-20 \\
\hline Constante & $0.556939 * * *$ & $0.647038^{* * *}$ & $18.1378^{* * *}$ & $19.9141^{* * *}$ \\
\hline DSAU/PIB & $-0.909583^{* * *}$ & $-2.68460^{* * *}$ & $-79.2625^{* * *}$ & $-69.4100^{* *}$ \\
\hline DEDU/PIB & $0.358573 * * *$ & $0.926580^{* * *}$ & $37.1960 * * *$ & $39.7386^{* * *}$ \\
\hline RNE & $0.0324631^{* * *}$ & $0.119989^{* * *}$ & $3.37025^{* * *}$ & $3.04758^{* * *}$ \\
\hline RCO & 0.00683613 & 0.00573540 & $1.40715^{* *}$ & $1.53359^{*}$ \\
\hline RSE & -0.00803980 & -0.0294297 & -0.779060 & -1.00278 \\
\hline RSU & $-0.0376963 * * *$ & $-0.108292^{* * *}$ & $-2.97554^{* * *}$ & $-2.79419^{* * *}$ \\
\hline ROYP/PIB & -1.31911 & $-6.45682^{* *}$ & $-214.384^{* *}$ & $-302.781^{* *}$ \\
\hline ROYSE/PIB & -5.69981 & -0.664666 & $-1306.94 * * *$ & $-2196.93 * * *$ \\
\hline $\begin{array}{c}\text { Normalidade dos Resíduos } \\
\text { (p-valor) }\end{array}$ & 0.180144 & 0.0580248 & $3.05432 \mathrm{e}-009$ & $2.46155 \mathrm{e}-022$ \\
\hline Número de Estados & 27 & 27 & 27 & 27 \\
\hline Número de Observações & 486 & 486 & 486 & 486 \\
\hline
\end{tabular}

Fonte: Elaborado pelo autor

Nota: ***Significativo a $1 \% ; * *$ Significativo a $5 \%$; *Significativo a $10 \%$. 
Tabela 19 - Resultados da regressão tobit em painel: gastos municipais

\begin{tabular}{|c|c|c|c|c|}
\hline Variáveis & Gini & Theil-T & P10-40 & P20-20 \\
\hline Constante & $0.564414 * * *$ & $0.629453 * * *$ & $19.8008 * * *$ & $22.1233^{* * * *}$ \\
\hline DSAU/PIB & $-3.24996 * * *$ & $-8.36520 * * *$ & $-360.445 * * *$ & $-432.942 * * *$ \\
\hline DEDU/PIB & $1.44029 * * *$ & $4.87553 * * *$ & $147.592 * * *$ & $193.594 * * *$ \\
\hline RNE & $0.0559801 * * *$ & $0.171950 * * *$ & $5.90264 * * *$ & $5.70446 * * *$ \\
\hline $\mathrm{RCO}$ & $0.0160185 * * *$ & $0.0458700 * * *$ & $1.97206^{* * *}$ & $1.98641 * * *$ \\
\hline RSE & 0.00173748 & 0.0101212 & -0.169669 & -0.597139 \\
\hline RSU & $-0.0327243 * * *$ & $-0.0775846^{* * *}$ & $-2.94343 * * *$ & $-3.04654 * * *$ \\
\hline ROYP/PIB & $-1.72736 * *$ & $-7.59521 * * *$ & $-245.021 * * *$ & $-317.034 * * *$ \\
\hline ROYSE/PIB & 3.87458 & 17.6831 & -187.318 & $-949.273^{*}$ \\
\hline $\begin{array}{l}\text { Normalidade dos Resíduos } \\
\text { (p-valor) }\end{array}$ & $8.50279 \mathrm{e}-005$ & 0.0297881 & 0.0100489 & $3.5735 \mathrm{e}-008$ \\
\hline Número de Estados & 27 & 27 & 27 & 27 \\
\hline Número de Observações & 486 & 486 & 486 & 486 \\
\hline
\end{tabular}

Fonte: Elaborado pelo autor

Nota: ***Significativo a $1 \%$; **Significativo a 5\%; *Significativo a $10 \%$.

Tabela 20 - Resultados da regressão tobit em painel: gastos estaduais e municipais

\begin{tabular}{|c|c|c|c|c|}
\hline Variáveis & Gini & Theil-T & P10-40 & P20-20 \\
\hline Constante & $0.575213 * * *$ & $0.671301 * * *$ & $20.5986 * * *$ & $22.8842 * * *$ \\
\hline DSAU/PIB & $-1.22996 * * *$ & $-2.92679 * * *$ & $-131.649 * * *$ & $-142.168 * * *$ \\
\hline DEDU/PIB & $0.396200 * * *$ & $1.02306 * * *$ & $42.7028 * * *$ & $48.6178 * * *$ \\
\hline RNE & $0.0385601 * * *$ & $0.140044 * * *$ & $3.83223 * * *$ & $3.38518 * * *$ \\
\hline $\mathrm{RCO}$ & 0.00120001 & 0.00363257 & 0.490297 & 0.332178 \\
\hline RSE & $-0.0143519 * * *$ & $-0.0317981 *$ & $-1.81669 * * *$ & $-2.37777 * * *$ \\
\hline RSU & $-0.0466334 * * *$ & $-0.116534 * * *$ & $-4.29985 * * *$ & $-4.47905 * * *$ \\
\hline ROYP/PIB & -0.928848 & $-5.85700 * *$ & $-159.569 *$ & $-230.497 *$ \\
\hline ROYSE/PIB & -1.06312 & 10.5760 & $-825.978^{*}$ & $-1695.13 * * *$ \\
\hline $\begin{array}{l}\text { Normalidade dos Resíduos } \\
\text { (p-valor) }\end{array}$ & 0.0220286 & 0.0457401 & $5.2545 \mathrm{e}-008$ & $2.7383 \mathrm{e}-019$ \\
\hline Número de Estados & 27 & 27 & 27 & 27 \\
\hline Número de Observações & 486 & 486 & 486 & 486 \\
\hline
\end{tabular}

Fonte: Elaborado pelo autor

Nota: $* * *$ Significativo a $1 \% ; * *$ Significativo a $5 \% ; *$ Significativo a $10 \%$.

Os resultados dessas três tabelas anteriores que utilizam o método painel tobit reforçam em grande medida os resultados evidenciados nos testes anteriores de que quanto maior proporção dos gastos em saúde sobre o PIB, maior a tendência de redução desigualdade de renda. De igual modo, há uma repetição do mesmo resultado controverso relacionado aos gastos com educação. O quadro a seguir mostra o resultado esperado e o resultado obtido em cada modelo. 
Quadro 27 - Resumos dos resultados obtidos na hipótese 1 - gastos por função

\begin{tabular}{|c|c|c|c|c|}
\hline Variável & $\begin{array}{c}\text { Sinal } \\
\text { esperado }\end{array}$ & $\begin{array}{c}\text { Sinal obtido em } 20 \\
\text { dos } 24 \text { casos com } \\
\text { significância } \\
\text { estatística }\end{array}$ & $\begin{array}{l}\text { Sinal obtido em } 24 \\
\text { dos } 24 \text { casos com } \\
\text { significância } \\
\text { estatística }\end{array}$ & Observação \\
\hline DSAU/PIB & $(-)$ & $(-)$ & $(-)$ & - \\
\hline DEDU/PIB & $(-)$ & $(+)$ & $(+)$ & $\begin{array}{l}\text { Resultado controverso à } \\
\text { luz da função } \\
\text { orçamentária alocativa. }\end{array}$ \\
\hline RNE & $(?)$ & $(+)$ & $(+)$ & - \\
\hline $\mathrm{RCO}$ & $(?)$ & Inconclusivo & Inconclusivo & - \\
\hline RSE & $(?)$ & Inconclusivo & Inconclusivo & - \\
\hline RSU & $(?)$ & $(-)$ & Inconclusivo & $\begin{array}{l}\text { Não obteve significância } \\
\text { estatística apenas nos } \\
\text { gastos municipais da } \\
\text { variável dependente P20- } \\
20 .\end{array}$ \\
\hline ROYP/PIB & $(-)$ & $(-)$ & Inconclusivo & $\begin{array}{l}\text { Não obteve significância } \\
\text { estatística em } 4 \text { casos. }\end{array}$ \\
\hline ROYSE/PIB & $(-)$ & Inconclusivo & Inconclusivo & - \\
\hline
\end{tabular}

Este resultado evidenciado em educação vai contra o resultado encontrado por Jha, Biswal e Biswal (2001), Sylwester (2002), De Mello e Tiongson (2006), Bergh e Fink (2008) e Zhang (2008). O resultado também vai contra os pressupostos de Cowell (2001) e Giacomoni (2012).

Tomando por base apenas o modelo dos Estados Unidos da América (EUA) cuja a ênfase dos recursos estatais concentra-se na educação fundamental e no ensino médio, deixando para o setor privado a maior parcela de iniciativa e responsabilidade pelo ensino superior; observa-se que no Brasil a iniciativa privada já concorre com o Estado desde o início do ensino fundamental. Assim, enquanto nos EUA a maioria da população (independente de classe) frequenta a escola pública até o ensino médio, no Brasil, parte considerável da população já ingressa no setor privado de ensino nos estágios iniciais.

Assim, o modelo brasileiro apresentou resultado empíricos que evidenciam o não alinhamento alinhado para a redução da desigualdade de renda segundo os pressupostos doutrinários da função alocativa.

\subsubsection{Gastos por subfunção da despesa}

Considerando os resultados na subseção anterior, especialmente os obtidos da função educação, fez-se necessário decompor os gastos em subfunções $-2^{\circ}$ nível da função. Desse modo, o modelo econométrico disposto na equação 16 foi reajustado conforme consta na equação 30 . 


$$
\begin{aligned}
& D E S_{i, t, j}=\beta_{0}+\beta_{1} \frac{\text { AtBas }}{P I B}_{i, t, s}+\beta_{1} \frac{\text { AssHosp }}{P I B}_{i, t, s}+\beta_{2} \frac{\text { Suprofilat }}{P I B}_{i, t, s}+\beta_{3} \frac{\text { VigSan }}{P I B}_{i, t, s}+\beta_{4} \frac{\text { VigEpi }}{P I B}_{i, t, s} \\
& +\beta_{5} \frac{\text { Ali }}{P I B}_{i, t, s}+\beta_{6} \frac{\text { OutrasSau }}{P I B}_{i, t, s}+\beta_{7} \frac{\text { Fund }}{P I B}_{i, t, s}+\beta_{8} \frac{\text { Medio }}{P I B}_{i, t, s}+\beta_{9} \frac{\text { Ensprof }}{P I B}_{i, t, s}+\beta_{10} \frac{\text { Supe }}{P I B}_{i, t, s} \\
& +\beta_{11} \frac{\text { Infantil }}{P I B}_{i, t, s}+\beta_{12} \frac{\text { EJA }}{P I B}_{i, t, s}+\beta_{13} \frac{\text { Especial }}{P I B}_{i, t, s}+\beta_{14} \frac{\text { OutrasEdu }}{P I B}+\beta_{15} R N E_{1}(1)+\beta_{16} R C O_{2}(1) \\
& +\beta_{17} R N E_{1}(1)+\beta_{18} R C O_{2}(1)+\beta_{19} R S E_{3}(1)+\beta_{20} R S U_{4}(1)+\beta_{21} \frac{R O Y P}{P I B}_{i, t}+\beta_{22} \frac{R O Y S E}{P I B}_{i, t}+\varepsilon_{i, t}
\end{aligned}
$$

Em que a variável “AtBas” representa os gastos na subfunção atenção básica; em que "AssHosp" representa os gastos na subfunção assistência hospitalar e ambulatorial; em que "Suprofilat" representa os gastos na subfunção suporte profilático e terapêutico; em que "VigSan" representa os gastos na subfunção vigilância sanitária; em que "VigEpi" representa os gastos na subfunção vigilância epidemiológica; em que "Ali" representa os gastos na subfunção alimentação e nutrição; em que "OutrasSau” representa os gastos na subfunção demais despesas com saúde. Essas variáveis anteriores representam a função saúde.

No que tange a função educação, a variável "Fund" representa os gastos na subfunção ensino fundamental; a variável "Medio" representa os gastos na subfunção ensino médio; a variável "Ensprof” representa os gastos no ensino profissional; a variável "Supe" representa os gastos na subfunção ensino superior; a variável "Infantil" representa os gastos na subfunção educação infantil; a variável "EJA" representa os gastos na subfunção educação de jovens e adultos; a variável "Especial" representa os gastos na subfunção educação especial; a variável "OutrasEdu” representa os gastos na subfunção demais despesas com educação. As demais variáveis já foram exploradas na equação 3.

As Tabelas 21, 22 e 23 contêm os resultados dos testes aplicados utilizando-se regressão de dados em painel com efeitos aleatórios. 
Tabela 21 - Resultados da regressão de dados em painel com efeitos aleatórios: gastos estaduais por subfunção

\begin{tabular}{|c|c|c|c|c|}
\hline Variáveis Dependentes & Gini & Theil-T & P10-40 & P20-20 \\
\hline Constante & $0.580487 * * *$ & $0.690847 * * *$ & $21.1458 * * *$ & $23.9630 * * *$ \\
\hline Atenção Básica/PIB & $-1.84681^{* * *}$ & $-4.80111 * *$ & $-143.016^{*}$ & -89.7942 \\
\hline Assistência Hospitalar/PIB & $-1.04326^{* * *}$ & $-1.91536^{* * * *}$ & $-116.614 * * *$ & $-151.175^{* * * *}$ \\
\hline Suporte Profilático/PIB & $-3.62828 * * *$ & $-13.6748 * * *$ & $-402.383^{* * * *}$ & $-385.407 *$ \\
\hline Vigilância Sanitária/PIB & $3.50043^{*}$ & $11.7162^{* *}$ & $335.970 *$ & 208.523 \\
\hline Vigilância Epidemiológica/PIB & $-17.3591 * *$ & $-62.4423 * * *$ & $-1825.84 * *$ & $-1813.81 *$ \\
\hline Alimentação/PIB & 24.8726 **** & $60.3527 * * *$ & $2165.62 * * *$ & $2436.13 * * *$ \\
\hline Outras Despesas com Saúde/PIB & $-1.77035^{* * * *}$ & $-4.15058 * * *$ & $-180.571^{* * *}$ & -215.039 *** \\
\hline Ensino Fundamental/PIB & 0.275745 & 0.609818 & 20.4063 & 20.2091 \\
\hline Ensino Médio/PIB & 0.517561 & 1.58550 & $62.3072 *$ & $120.081 * * *$ \\
\hline Ensino Profissionalizante/PIB & $-7.64435 * *$ & $-21.4456 * *$ & $-705.689 *$ & $-889.325 * *$ \\
\hline Ensino Superior/PIB & 0.872032 & 0.143575 & 130.713 & 184.524 \\
\hline Educação Infantil/PIB & -2.42889 & -5.29976 & -550.743 & -900.227 \\
\hline Educação de Jovens e Adultos/PIB & -2.64825 & -17.3825 & -429.278 & -576.961 \\
\hline Educação Especial/PIB & -3.71307 & -2.92452 & -398.568 & -977.379 \\
\hline Outras Despesas com Educação/PIB & $0.569316^{* * *}$ & $2.00500 * * *$ & $69.3163^{* * * *}$ & $79.8155^{* * * *}$ \\
\hline RNE & $0.0241249^{* * *}$ & $0.100067 * * *$ & $2.24038 * *$ & 1.22289 \\
\hline $\mathrm{RCO}$ & -0.0123475 & -0.0251276 & -1.27916 & -2.24958 \\
\hline RSE & $-0.0209712 *$ & $-0.0622320 * *$ & $-2.28688^{*}$ & $-3.15216^{*}$ \\
\hline RSU & $-0.0547583 * * *$ & $-0.137853 * * *$ & $-5.39020 * * *$ & $-6.26255^{* * * *}$ \\
\hline ROYP/PIB & $-2.67537 * *$ & $-6.30903 *$ & $-341.516 * * * *$ & $-348.528 * *$ \\
\hline ROYSE/PIB & -7.46865 & -8.17348 & $-1191.55^{*}$ & $-1618.75 * *$ \\
\hline Pooled Simples & Não & Não & Não & Não \\
\hline Efeitos Fixos & Não & Não & Não & Não \\
\hline Efeitos Aleatórios & Sim & Sim & Sim & Sim \\
\hline Breusch-Pagan & $3.42159 \mathrm{e}-049$ & $2.89191 \mathrm{e}-019$ & $5.14601 \mathrm{e}-075$ & $1.15528 \mathrm{e}-079$ \\
\hline Hausman & $3.02988 \mathrm{e}-005$ & $5.25793 \mathrm{e}-005$ & $1.62083 \mathrm{e}-007$ & $2.07127 \mathrm{e}-006$ \\
\hline Normalidade dos Resíduos (p-valor) & 0.13650 & 0.00000 & 0.00000 & 0.00000 \\
\hline Número de Estados & 27 & 27 & 27 & 27 \\
\hline Número de Observações & 486 & 486 & 486 & 486 \\
\hline
\end{tabular}

Fonte: Elaborado pelo autor

Nota: ***Significativo a $1 \%$; **Significativo a $5 \%$; *Significativo a $10 \%$.

Tabela 22 - Resultados da regressão de dados em painel com efeitos aleatórios: gastos municipais por subfunção

\begin{tabular}{|c|c|c|c|c|}
\hline Variáveis Dependentes & Gini & Theil-T & P10-40 & P20-20 \\
\hline Constante & 0.572496 *** & 0.652921 *** & $20.4815 * * *$ & $22.5547 * * *$ \\
\hline Atenção Básica/PIB & $-2.03394 * * *$ & $-6.18242 * * *$ & $-195.094 * * *$ & -306.391 *** \\
\hline Assistência Hospitalar/PIB & $-2.54150 * * *$ & $-5.34850^{* *}$ & $-271.144 * * *$ & $-313.770 * * *$ \\
\hline Suporte Profilático/PIB & -5.49548 & 5.11837 & -507.790 & -630.393 \\
\hline Vigilância Sanitária/PIB & -9.96533 & -20.9892 & -1219.18 & -1531.81 \\
\hline Vigilância Epidemiológica/PIB & 4.82356 & 18.0290 & 432.052 & 821.962 \\
\hline Alimentação/PIB & 1.43781 & -8.14817 & -25.9554 & -371.581 \\
\hline Outras Despesas com Saúde/PIB & $-3.11829 * * *$ & $-8.59192 * * *$ & $-273.426^{* * *}$ & $-276.654 * *$ \\
\hline Ensino Fundamental/PIB & 0.0918466 & 1.21660 & -20.5325 & 39.6767 \\
\hline Ensino Médio/PIB & -12.4323 & -45.3980 & -1178.87 & -559.247 \\
\hline Ensino Profissionalizante/PIB & $21.2048 * *$ & 49.7733 & $2489.49 * *$ & $3840.81 * * *$ \\
\hline Ensino Superior/PIB & 10.7544 & $59.5976 * *$ & 1014.07 & 1155.91 \\
\hline Educação Infantil/PIB & $-2.31512^{*}$ & -5.67505 & -182.005 & $-445.860 * * *$ \\
\hline Educação de Jovens e Adultos/PIB & $18.6883^{*}$ & 35.1970 & 1587.47 & 1020.89 \\
\hline Educação Especial/PIB & 29.3504 & 83.7473 & 2619.90 & 3172.27 \\
\hline Outras Despesas com Educação/PIB & $2.33396 * *$ & $6.32648 *$ & $236.882 * *$ & $335.694 * *$ \\
\hline RNE & $0.0573613 * * *$ & $0.176681^{* * *}$ & $5.97402 * * *$ & $5.61496^{* * * *}$ \\
\hline $\mathrm{RCO}$ & 0.0106152 & 0.0365118 & 0.818894 & 0.854527 \\
\hline RSE & 0.00775788 & 0.0121886 & 0.803765 & 0.686329 \\
\hline RSU & -0.0246842 & $-0.0555170^{*}$ & -2.31838 & -1.81329 \\
\hline ROYP/PIB & $-2.44920^{* *}$ & $-7.28084^{* *}$ & $-286.052 * *$ & $-251.244 *$ \\
\hline ROYSE/PIB & -8.15835 & -16.2655 & $-1143.69 *$ & $-1564.12 * *$ \\
\hline Pooled Simples & Não & Não & Não & Não \\
\hline Efeitos Fixos & Não & Não & Não & Não \\
\hline Efeitos Aleatórios & Sim & Sim & Sim & Sim \\
\hline Breusch-Pagan & $8.1158 \mathrm{e}-039$ & $2.67958 \mathrm{e}-011$ & $1.11611 \mathrm{e}-068$ & $6.45252 \mathrm{e}-080$ \\
\hline Hausman & 0.284564 & 0.000199175 & 0.721588 & 0.959708 \\
\hline Normalidade dos Resíduos (p-valor) & 0.00020 & 0.00000 & 0.00044 & 0.00000 \\
\hline Número de Estados & 27 & 27 & 27 & 27 \\
\hline Número de Observações & 486 & 486 & 486 & 486 \\
\hline
\end{tabular}

Fonte: Elaborado pelo autor

Nota: $* *$ Significativo a $1 \% ; * *$ Significativo a $5 \%$; *Significativo a $10 \%$. 
Tabela 23 - Resultados da regressão de dados em painel com efeitos aleatórios: gastos estaduais e municipais por subfunção

\begin{tabular}{|c|c|c|c|c|}
\hline Variáveis & Gini & Theil-T & P10-40 & P20-20 \\
\hline Constante & $0.592063 * * *$ & $0.699584 * * *$ & $22.7320 * * *$ & $25.4663 * * *$ \\
\hline Atenção Básica/PIB & $-1.62880 * * *$ & $-4.33788 * * *$ & $-142.536 * * *$ & $-151.748 * * *$ \\
\hline Assistência Hospitalar/PIB & $-0.896511 * * *$ & $-1.54695 * *$ & $-102.057 * * *$ & $-127.739 * * *$ \\
\hline Suporte Profilático/PIB & -2.46855 & $-11.5329 * *$ & -271.192 & -279.698 \\
\hline Vigilância Sanitária/PIB & $2.71942 *$ & $10.3174 * *$ & 238.018 & 192.171 \\
\hline Vigilância Epidemiológica/PIB & -2.63596 & -11.6062 & -223.875 & 305.761 \\
\hline Alimentação/PIB & $24.2621 * * *$ & $60.7324 * * *$ & $2115.62 * * *$ & $2426.86 * * *$ \\
\hline Outras Despesas com Saúde/PIB & $-1.56938 * * *$ & $-3.90410 * * *$ & $-154.448 * * *$ & $-181.452 * * *$ \\
\hline Ensino Fundamental/PIB & 0.141669 & 0.709120 & -2.36942 & 2.63307 \\
\hline Ensino Médio/PIB & 0.397477 & 1.06433 & 52.0858 & $107.006 * * *$ \\
\hline Ensino Profissionalizante/PIB & -3.06669 & -14.5197 & -315.811 & -275.871 \\
\hline Ensino Superior/PIB & -0.633985 & -3.73860 & 13.8952 & 78.1951 \\
\hline Educação Infantil/PIB & -1.32398 & -0.637495 & -126.427 & $-330.519 * *$ \\
\hline Educação de Jovens e Adultos/PIB & 1.26820 & -7.89295 & -28.1954 & -344.773 \\
\hline Educação Especial/PIB & -4.03018 & 0.416241 & -491.020 & -791.227 \\
\hline Outras Despesas com Educação/PIB & $0.365304 * *$ & $1.62200 * * *$ & $38.5048^{* *}$ & 37.1884 \\
\hline RNE & $0.0382594 * * *$ & $0.139006 * * *$ & $3.71620 * * *$ & $3.14136 *$ \\
\hline $\mathrm{RCO}$ & -0.00957420 & -0.00978471 & -1.40620 & -1.74430 \\
\hline RSE & -0.0168189 & -0.0452869 & -1.91390 & -2.53171 \\
\hline RSU & $-0.0487553 * * *$ & $-0.117201 * * *$ & $-5.05993 * *$ & $-5.24069 * *$ \\
\hline ROYP/PIB & -1.89450 & -5.07811 & $-253.361 * *$ & -208.650 \\
\hline ROYSE/PIB & -4.75654 & -5.03475 & -818.126 & -1122.77 \\
\hline Pooled Simples & Não & Não & Não & Não \\
\hline Efeitos Fixos & Não & Não & Não & Não \\
\hline Efeitos Aleatórios & Sim & Sim & Sim & Sim \\
\hline Breusch-Pagan & $9.1824 \mathrm{e}-044$ & $8.84412 \mathrm{e}-016$ & $2.34632 \mathrm{e}-080$ & $1.8724 \mathrm{e}-084$ \\
\hline Hausman & 0.391379 & 0.0458532 & 0.401116 & 0.15794 \\
\hline Normalidade dos Resíduos (p-valor) & 0.00112 & 0.00000 & 0.00000 & 0.00000 \\
\hline Número de Estados & 27 & 27 & 27 & 27 \\
\hline Número de Observações & 486 & 486 & 486 & 486 \\
\hline
\end{tabular}

Fonte: Elaborado pelo autor

Nota: ***Significativo a $1 \%$; * Significativo a $5 \%$; *Significativo a $10 \%$.

As Tabelas 24, 25 e 26 contêm os resultados dos testes aplicados utilizando-se

regressão tobit em painel.

Tabela 24 - Resultados da regressão tobit em Painel: gastos estaduais por subfunção

\begin{tabular}{ccccc}
\hline Variáveis Dependentes & Gini & Theil-T & P10-40 & P20-20 \\
\hline Constante & $0.56584^{* * *}$ & $0.675731^{* * *}$ & $19.2196^{* * *}$ & $21.0533^{* * *}$ \\
\hline Atenção Básica/PIB & -0.711932 & -3.52241 & -6.72067 & 84.8793 \\
\hline Assistência Hospitalar/PIB & -0.356024 & $-1.29781^{* *}$ & -22.2708 & -15.5305 \\
\hline Suporte Profilático/PIB & $-4.83376^{* * *}$ & $-15.7260^{* * *}$ & $-579.189^{* * *}$ & $-650.923^{* * *}$ \\
\hline Vigilância Sanitária/PIB & $5.85043^{* * *}$ & $14.5268^{* * *}$ & $593.763^{* * *}$ & $565.855^{* * *}$ \\
\hline Vigilância Epidemiológica/PIB & -13.1531 & $-58.7018^{* *}$ & -1239.87 & -870.346 \\
\hline Alimentação/PIB & $27.0179^{* * *}$ & $65.8712^{* * *}$ & $2443.27^{* * *}$ & $2685.72^{* * *}$ \\
\hline Outras Despesas com Saúde/PIB & $-1.31725^{* * *}$ & $-3.28439^{* * *}$ & $-109.048^{* * *}$ & $-111.954^{* *}$ \\
\hline Ensino Fundamental/PIB & 0.121367 & 0.175611 & 3.50611 & 7.04070 \\
\hline Ensino Médio/PIB & $0.762819^{* * *}$ & $2.14122^{* * *}$ & $86.4411^{*}$ & $147.221^{* * *}$ \\
\hline Ensino Profissionalizante/PIB & -3.37386 & -11.8530 & -296.403 & -383.162 \\
\hline Ensino Superior/PIB & -1.15179 & -3.28054 & -74.0420 & -113.554 \\
\hline Educação Infantil/PIB & $10.2995^{* *}$ & 7.15094 & $1433.74 * * *$ & $1759.31^{* * *}$ \\
\hline Educação de Jovens e Adultos/PIB & -5.35652 & $-21.5651^{*}$ & -689.082 & $-942.849^{*}$ \\
\hline Educação Especial/PIB & 2.55881 & 3.43071 & 392.049 & 202.380 \\
\hline Outras Despesas com Educação/PIB & 0.242184 & $1.66219^{* * *}$ & 13.1974 & 9.50129 \\
\hline RNE & $0.0277637 * * *$ & $0.103417^{* * *}$ & $2.86652^{* * *}$ & $2.40020^{* * *}$ \\
\hline RCO & 0.000968733 & -0.0136749 & 0.710225 & 0.833025 \\
\hline RSE & $-0.0162977 * *$ & $-0.0565973^{* * *}$ & $-1.63700^{* *}$ & $-1.85121^{* *}$ \\
\hline RSU & $-0.0464039^{* * *}$ & $-0.133338^{* * *}$ & $-4.05600^{* * *}$ & $-3.91076^{* * *}$ \\
\hline ROYP/PIB & -1.22475 & $-5.55411^{*}$ & $-227.460^{*}$ & $-322.965^{* *}$ \\
\hline ROYSE/PIB & -3.19567 & 7.72917 & $-1114.91 * *$ & $-2118.86^{* * *}$ \\
\hline Normalidade dos Resíduos (p-valor) & 0.014508 & 0.0178292 & $1.27 \mathrm{e}-006$ & $8.6544 \mathrm{e}-016$ \\
\hline Número de Estados & 27 & 27 & 27 & 27 \\
\hline Número de Observações & 486 & 486 & 486 & 486 \\
\hline Fon & & &
\end{tabular}

Fonte: Elaborado pelo autor

Nota: ***Significativo a $1 \%$; **Significativo a 5\%; *Significativo a $10 \%$. 
Tabela 25 - Resultados da regressão tobit em Painel: gastos municipais por subfunção

\begin{tabular}{|c|c|c|c|c|}
\hline Variáveis Dependentes & Gini & Theil-T & P10-40 & P20-20 \\
\hline Constante & $0.568551 * * *$ & $0.637489 * * *$ & $20.3360 * * *$ & $22.6502 * * *$ \\
\hline Atenção Básica/PIB & $-2.64721 * * *$ & $-7.51349 * * *$ & $-259.741 * * *$ & $-339.604 * * *$ \\
\hline Assistência Hospitalar/PIB & $-2.28462 * * *$ & $-4.22348 * *$ & $-259.639 * * *$ & $-330.704 * * *$ \\
\hline Suporte Profilático/PIB & 11.5342 & 28.9900 & $1472.53 *$ & $1841.02 *$ \\
\hline Vigilância Sanitária/PIB & 1.90910 & -12.2808 & 124.615 & 598.247 \\
\hline Vigilância Epidemiológica/PIB & 11.2041 & 30.1665 & 1068.96 & $1591.86^{*}$ \\
\hline Alimentação/PIB & -18.9902 & -20.9494 & -2217.12 & -3267.36 \\
\hline Outras Despesas com Saúde/PIB & $-5.10658 * * *$ & $-12.4331 * * *$ & $-522.942 * *$ & $-553.692 * * *$ \\
\hline Ensino Fundamental/PIB & $0.930039 * * *$ & 3.04759 & $74.5875 * *$ & $108.175 * *$ \\
\hline Ensino Médio/PIB & $-21.4922 * *$ & $-59.6665 * *$ & $-2462.66^{* *}$ & $-2286.71^{*}$ \\
\hline Ensino Profissionalizante/PIB & 7.57272 & 20.2995 & 1023.64 & $2261.00 *$ \\
\hline Ensino Superior/PIB & $20.2427 * * *$ & $74.3591 * * *$ & $2126.51 * * *$ & $2333.01 * *$ \\
\hline Educação Infantil/PIB & $-4.42682 * * *$ & $-8.27138 * *$ & $-423.490 * * *$ & $-660.402 * * *$ \\
\hline Educação de Jovens e Adultos/PIB & 9.65578 & 18.5396 & 858.914 & 854.450 \\
\hline Educação Especial/PIB & $33.8695 *$ & 94.8688 & 1630.00 & 720.818 \\
\hline Outras Despesas com Educação/PIB & 1.32658 & 4.65999 & 108.375 & $261.330 *$ \\
\hline RNE & $0.0539289 * * *$ & $0.167720 * * *$ & $5.72410 * * *$ & $5.49636 * * *$ \\
\hline $\mathrm{RCO}$ & $0.0143536 * * *$ & $0.0398145^{* *}$ & $1.71563 * * *$ & $1.93881 * * *$ \\
\hline RSE & 0.00634491 & 0.0139220 & 0.315911 & 0.281851 \\
\hline RSU & $-0.0241827 * * *$ & $-0.0559703 * * *$ & $-2.11089 * * *$ & $-1.41746^{*}$ \\
\hline ROYP/PIB & $-1.58276^{*}$ & $-6.37447 * *$ & $-260.231 * * *$ & $-343.131 * * *$ \\
\hline ROYSE/PIB & -2.06360 & -1.98847 & $-755.960 *$ & $-1613.09 * * *$ \\
\hline Normalidade dos Resíduos (p-valor) & 0.000890747 & 0.00387232 & 0.000696878 & $1.23774 \mathrm{e}-006$ \\
\hline Número de Estados & 27 & 27 & 27 & 27 \\
\hline Número de Observações & 486 & 486 & 486 & 486 \\
\hline
\end{tabular}

Fonte: Elaborado pelo autor

Nota: ***Significativo a $1 \%$; **Significativo a $5 \%$; *Significativo a $10 \%$.

Tabela 26 - Resultados da regressão tobit em Painel: gastos estaduais e municipais por subfunção

\begin{tabular}{|c|c|c|c|c|}
\hline Variáveis & Gini & Theil-T & P10-40 & P20-20 \\
\hline Constante & $0.575396 * * *$ & $0.674291 * * *$ & $20.6067 * * *$ & $22.8254 * * *$ \\
\hline Atenção Básica/PIB & $-2.39178 * * *$ & $-5.43437 * * *$ & $-245.702 * * *$ & $-282.771 * * *$ \\
\hline Assistência Hospitalar/PIB & $-0.495413 * *$ & $-1.37876^{* *}$ & $-46.8802 * *$ & $-51.8949 * *$ \\
\hline Suporte Profilático/PIB & $-3.92013 * *$ & $-13.1948 * * *$ & $-476.817 * * *$ & $-540.618 * * *$ \\
\hline Vigilância Sanitária/PIB & $7.82908 * * *$ & $16.2263 * * *$ & $879.253 * * *$ & $955.012 * * *$ \\
\hline Vigilância Epidemiológica/PIB & 3.41812 & 9.42395 & 342.977 & 827.185 \\
\hline Alimentação/PIB & $27.6665 * * *$ & $75.6432 * * *$ & $2504.42 * * *$ & $2676.00 * * *$ \\
\hline Outras Despesas com Saúde/PIB & $-1.58751 * * *$ & $-4.26183 * * *$ & $-142.379 * * *$ & $-146.751 * * *$ \\
\hline Ensino Fundamental/PIB & $00.351056 * *$ & $1.12434 * *$ & 24.2566 & 29.7841 \\
\hline Ensino Médio/PIB & $0.695654 * *$ & 1.46531 & $89.7779 * * *$ & $154.851 * * *$ \\
\hline Ensino Profissionalizante/PIB & 2.95764 & -6.26318 & 503.478 & $767.076^{*}$ \\
\hline Ensino Superior/PIB & $-2.35601 *$ & $-5.85181 *$ & -197.179 & -218.671 \\
\hline Educação Infantil/PIB & $-2.92210 * * *$ & -2.11147 & $-323.022 * * *$ & $-528.758 * * *$ \\
\hline Educação de Jovens e Adultos/PIB & -5.25963 & $-20.4105 * *$ & $-686.210^{*}$ & $-957.883 * *$ \\
\hline Educação Especial/PIB & 4.64552 & 9.84816 & 516.663 & 336.848 \\
\hline $\begin{array}{l}\text { Outras Despesas com } \\
\text { Educação/PIB }\end{array}$ & $0.412817 * *$ & $1.63695 * * *$ & $37.0938 * *$ & 35.2432 \\
\hline RNE & $0.0439733 * * *$ & $0.147030 * * *$ & $4.55258 * * *$ & $4.34578 * * *$ \\
\hline $\mathrm{RCO}$ & 0.00684409 & 0.00835519 & $1.16473^{*}$ & $1.39719 *$ \\
\hline RSE & $-0.0116292 *$ & $-0.0359681 * *$ & $-1.41560 * *$ & $-1.51920^{*}$ \\
\hline RSU & $-0.0351997 * * *$ & $-0.104142 * * *$ & $-3.00584 * * *$ & $-2.37348 * * *$ \\
\hline ROYP/PIB & -0.409078 & -4.45516 & -118.421 & -170.402 \\
\hline ROYSE/PIB & 2.71206 & 16.9796 & -394.370 & $-1167.26 * *$ \\
\hline $\begin{array}{l}\text { Normalidade dos Resíduos (p- } \\
\text { valor) }\end{array}$ & 0.0428458 & 0.00174137 & $4.14658 \mathrm{e}-005$ & $7.74719 \mathrm{e}-01$ \\
\hline Número de Estados & 27 & 27 & 27 & 27 \\
\hline Número de Observações & 486 & 486 & 486 & 486 \\
\hline
\end{tabular}

Fonte: Elaborado pelo autor

Nota: $* * *$ Significativo a $1 \% ; * *$ Significativo a $5 \%$; $*$ Significativo a $10 \%$. 
Quadro 28 - Resumos dos resultados obtidos na hipótese 1 - gastos por subfunção

\begin{tabular}{|c|c|c|c|}
\hline Variável & $\begin{array}{c}\text { Sinal } \\
\text { esperado }\end{array}$ & $\begin{array}{c}\text { Sinal obtido em } 20 \text { dos } 24 \\
\text { casos com significância } \\
\text { estatística }\end{array}$ & $\begin{array}{c}\text { Sinal obtido em } 24 \text { dos } 24 \\
\text { casos com significância } \\
\text { estatística }\end{array}$ \\
\hline Atenção Básica/PIB & $(-)$ & $(-)$ & Inconclusivo \\
\hline Assistência Hospitalar/PIB & $(-)$ & $(-)$ & Inconclusivo \\
\hline Suporte Profilático/PIB & $(-)$ & Inconclusivo & Inconclusivo \\
\hline Vigilância Sanitária/PIB & $(-)$ & Inconclusivo & Inconclusivo \\
\hline $\begin{array}{c}\text { Vigilância } \\
\text { Epidemiológica/PIB }\end{array}$ & $(-)$ & Inconclusivo & Inconclusivo \\
\hline Alimentação/PIB & $(-)$ & Inconclusivo & Inconclusivo \\
\hline $\begin{array}{c}\text { Outras Despesas com } \\
\text { Saúde/PIB }\end{array}$ & $(-)$ & $(-)$ & $(-)$ \\
\hline Ensino Fundamental/PIB & $(-)$ & Inconclusivo & Inconclusivo \\
\hline Ensino Médio/PIB & $(-)$ & Inconclusivo & Inconclusivo \\
\hline $\begin{array}{c}\text { Ensino } \\
\text { Profissionalizante/PIB }\end{array}$ & $(-)$ & Inconclusivo & Inconclusivo \\
\hline Ensino Superior/PIB & $(-)$ & Inconclusivo & Inconclusivo \\
\hline Educação Infantil/PIB & $(-)$ & Inconclusivo & Inconclusivo \\
\hline $\begin{array}{l}\text { Educação de Jovens e } \\
\text { Adultos/PIB }\end{array}$ & $(-)$ & Inconclusivo & Inconclusivo \\
\hline Educação Especial/PIB & $(-)$ & Inconclusivo & Inconclusivo \\
\hline $\begin{array}{l}\text { Outras Despesas com } \\
\text { Educação/PIB }\end{array}$ & $(-)$ & Inconclusivo & Inconclusivo \\
\hline RNE & $(?)$ & $(+)$ & Inconclusivo \\
\hline $\mathrm{RCO}$ & (?) & Inconclusivo & Inconclusivo \\
\hline RSE & $(?)$ & Inconclusivo & Inconclusivo \\
\hline RSU & (?) & $(-)$ & Inconclusivo \\
\hline ROYP/PIB & $(-)$ & Inconclusivo & Inconclusivo \\
\hline ROYSE/PIB & $(-)$ & Inconclusivo & Inconclusivo \\
\hline
\end{tabular}

Fonte: Elaborado pelo autor

Em que pese ter ocorrido a decomposição das despesas por subfunção, as despesas na área educação proporcionalmente ao PIB dos Estados mostraram-se inconclusivas. Assim, o resultado antes controverso na literatura, mostra-se agora como inconclusivo.

Este resultado mostra que empiricamente pode-se afirmar que o modelo adotado pelos estados e municípios para os gastos em educação não contribui para a redução da desigualdade de renda.

Quanto às despesas por subfunção na área de saúde, as despesas em atenção básica, Assistência Hospitalar e Outras Despesas com Saúde foram preponderantes perante as demais na redução da desigualdade de renda dos estados. 


\subsection{Resultados da Hipótese 2}

Os resultados nesta subseção serão apresentados em quatro perspectivas: (i) efeitos dos impostos progressivos municipais sobre a desigualdade de renda da população do estado - subseção 4.2.1, (ii) efeitos dos impostos progressivos estaduais sobre a desigualdade de renda da população do estado - subseção 4.2.2, (iii) efeitos dos impostos progressivos federais sobre a desigualdade de renda da população do estado - subseção 4.2.3, (iv) efeitos simultâneos dos impostos progressivos sobre a desigualdade de renda da população do estado - seção 4.2.4.

Para cada perspectiva serão aplicados dois métodos estatísticos: (i) regressão de dados em painel com efeitos aleatórios e (ii) regressão tobit em painel.

Considerando as limitações expostas na Tabela 10 foram considerados dois períodos de análise: 2001 a 2012; e 1995 a 2012.

A seguir, nas seções 4.2.1, 4.2.2 e 4.2.3 serão aplicados os modelos considerando a base de dados disponibilizada pelos órgãos públicos considerando apenas o período de 2001 a 2012, enquanto na seção 4.2.4 serão aplicados os testes na base de dados tanto para o período de 2001 a 2012, quanto para o período de 1995 a 2012 (base ajustada conforme metodologia descrita na seção 3).

\subsubsection{Impacto dos Impostos Progressivos Municipais}

As Tabelas 27 e 28 contêm os resultados dos testes aplicados utilizando-se respectivamente: regressão de dados em painel com efeitos aleatórios e regressão tobit em painel.

Observa-se na Tabela 27 que no âmbito dos impostos municipais incidentes sobre a população dos estados, o ITBI em que pese não ser progressivo juridicamente mostrou sinal inverso e significativo para os quatro indicadores de desigualdade de renda. Dessa forma, conclui-se a arrecadação do ITBI contribuiu para a redução das desigualdades de renda no período de 2001 a 2012.

O resultado do IPTU foi inconclusivo em dois cenários e controverso em outros dois: P10-40 e P20-20. Por se progressivo nestes dois últimos casos, deveria ser se obtido um sinal negativo e não positivo com significância estatística.

Os resultados dos royalties do petróleo e do setor elétrico mostraram-se inconclusivos em todos os cenários. 
Tabela 27 - Resultados da regressão de dados em painel com efeitos aleatórios: impostos progressivos municipais 2001-2012

\begin{tabular}{ccccc}
\hline Variáveis & Gini & Theil-T & P10-40 & P20-20 \\
\hline Constante & $0.552851^{* * *}$ & $0.614561^{* * *}$ & $17.8537 * * *$ & $19.7362^{* * *}$ \\
\hline IPTU/PIB & 2.82794 & 5.23655 & $397.258^{* *}$ & $414.335^{* *}$ \\
\hline ITBI/PIB & $-46.6200^{* * *}$ & $-95.6176 * * *$ & $-4565.55^{* * *}$ & $-4856.23 * * *$ \\
\hline RNE & $0.0487158^{* * *}$ & $0.153704 * * *$ & $4.50108^{* * *}$ & $4.54512^{* *}$ \\
\hline RCO & $0.0454369^{* * *}$ & $0.106001 * * *$ & $4.53538^{* *}$ & $4.57453 * *$ \\
\hline RSE & 0.0305446 & 0.0539002 & 2.82166 & 2.74303 \\
\hline RSU & -0.0101544 & -0.0312159 & -0.488277 & -0.687961 \\
\hline ROYP/PIB & -1.08201 & -0.854693 & -142.677 & -254.662 \\
\hline ROYSE/PIB & 9.55066 & 29.6614 & 323.806 & 175.735 \\
\hline Pooled Simples & Não & Não & Não & Não \\
\hline Efeitos Fixos & Não & Não & Não & Não \\
\hline Efeitos Aleatórios & Sim & Sim & Sim & Sim \\
\hline Teste de Breusch-Pagan (p-valor) & $7.78622 \mathrm{e}-066$ & $1.03942 \mathrm{e}-013$ & $7.21336 \mathrm{e}-087$ & $1.01287 \mathrm{e}-085$ \\
\hline Teste de Hausman (p-valor) & 0.23688 & 0.642019 & 0.452855 & 0.5332 \\
\hline Normalidade dos Resíduos (p- & 0.95641 & 0.00000 & 0.00000 & 0.00000 \\
valor) & 27 & 27 & 27 & 27 \\
\hline Número de Estados & 324 & 324 & 324 & 324 \\
\hline Número de Observações & & &
\end{tabular}

Fonte: Elaborado pelo autor

Nota: $* * *$ Significativo a $1 \% ; * *$ Significativo a $5 \% ; *$ Significativo a $10 \%$.

O efeito regional foi significativo nas Regiões Nordeste e Centro-Oeste em relação a Região Norte. Isso mostra que para cada ponto percentual no indicador de desigualdade de renda coeficiente de Gini, a região nordeste obteve um valor 4,8\% maior e a região Centro-Oeste obteve um valor $4,5 \%$ maior. Dessa forma, a região Norte nesse cenário e com as mesmas variáveis reduziu no período a desigualdade de renda em maior intensidade que essas duas regiões.

Quanto ao diagnóstico do painel, nos quatro casos, considerando os resultados dos testes de Chow e Breusch-Pagan, conclui-se que o modelo de dados em painel seria mais apropriado ao modelo pooled simples. Quanto ao teste de Hausman, verifica-se que o painel de efeitos aleatórios teria preferência sobre o painel de efeitos fixos em todos os cenários. 
Tabela 28 - Resultados da regressão tobit em painel: impostos progressivos municipais 2001-2012

\begin{tabular}{ccccc}
\hline Variáveis & Gini & Theil-T & P10-40 & P20-20 \\
\hline Constante & $0.548992^{* * *}$ & $0.610153 * * *$ & $17.7665^{* * *}$ & $19.9725^{* * *}$ \\
\hline IPTU/PIB & 2.20253 & 2.39951 & 258.120 & 298.546 \\
\hline ITBI/PIB & $-36.4785^{* * *}$ & $-77.4933^{* * *}$ & $-3970.22^{* * *}$ & $-4801.66^{* * *}$ \\
\hline RNE & $0.0404184^{* * *}$ & $0.146533 * *$ & $3.93122^{* * *}$ & $4.05711^{* * *}$ \\
\hline RCO & $0.0455842^{* * *}$ & $0.102422^{* * *}$ & $5.56956^{* * *}$ & $6.37849^{* * *}$ \\
\hline RSE & 0.0123332 & 0.0382182 & 1.18964 & 1.20988 \\
\hline RSU & $-0.0146502^{*}$ & $-0.0386237^{*}$ & -0.314847 & 0.173956 \\
\hline ROYP/PIB & $1.80424 *$ & 0.263667 & 143.161 & 99.7047 \\
\hline ROYSE/PIB & 4.80323 & $25.9123 *$ & -308.688 & $-1064.26^{*}$ \\
\hline $\begin{array}{c}\text { Normalidade dos Resíduos } \\
\text { (p-valor) }\end{array}$ & 0.894687 & 0.00016145 & $1.70738 \mathrm{e}-006$ & $3.21653 \mathrm{e}-009$ \\
\hline Número de Estados & 27 & 27 & 27 & 27 \\
\hline Número de Observações & 324 & 324 & 324 & 324 \\
\hline
\end{tabular}

Fonte: Elaborado pelo autor

Nota: ***Significativo a $1 \% ; * *$ Significativo a $5 \% ; *$ Significativo a $10 \%$

O resultado na Tabelas 28 confirma o comportamento do ITBI em relação aos indicadores de desigualdade de renda: relação inversa e significativa; enquanto o resultado do IPTU foi inconclusivo. O efeito regional foi conclusivo novamente para as Regiões Nordeste e Centro-Oeste em relação a Região Norte, confirmando o resultado da Tabela 27.

\subsubsection{Impacto dos Impostos Progressivos Estaduais}

As Tabelas 29 e 30 contêm os resultados dos testes aplicados utilizando-se respectivamente: regressão de dados em painel com efeitos aleatórios e regressão tobit em painel.

Tabela 29 - Resultados da regressão de dados em painel com efeitos aleatórios: impostos progressivos estaduais 2001-2012

\begin{tabular}{ccccc}
\hline Variáveis & Gini & Theil-T & P10-40 & P20-20 \\
\hline Constante & $0.557250^{* * *}$ & $0.623990^{* * *}$ & $18.5148^{* * *}$ & $20.5433^{* * *}$ \\
\hline IPVA/PIB & $-4.51826^{* * *}$ & $-9.63957^{* * *}$ & $-489.409^{* * *}$ & $-536.726^{* * *}$ \\
\hline ITCMD/PIB & $-78.2988^{* * *}$ & $-145.588^{* * *}$ & $-7169.73^{* * *}$ & $-8173.71^{* * *}$ \\
\hline RNE & $0.0397550^{* * *}$ & $0.135432^{* * *}$ & $3.72972^{* * *}$ & $3.77473^{* * *}$ \\
\hline RCO & $0.0532636^{* * *}$ & $0.102358^{* * *}$ & $5.72184^{* *}$ & $6.11370^{* * *}$ \\
\hline RSE & $0.0330934^{* *}$ & $0.0656985^{*}$ & $3.01465 * * *$ & $3.15896^{* * *}$ \\
\hline RSU & -0.00918511 & -0.0354000 & -0.208471 & -0.169184 \\
\hline ROYP/PIB & -1.50329 & -5.99988 & -192.777 & -312.291 \\
\hline ROYSE/PIB & 11.8842 & $37.7877 *$ & 575.424 & 410.059 \\
\hline Pooled Simples & Não & Não & Não & Não \\
\hline Efeitos Fixos & Não & Não & Não & Não \\
\hline Efeitos Aleatórios & Sim & Sim & Sim & Sim \\
\hline $\begin{array}{c}\text { Teste de Breusch-Pagan } \\
\text { (p-valor) }\end{array}$ & $3.18783 \mathrm{e}-060$ & $1.44566 \mathrm{e}-011$ & $4.50361 \mathrm{e}-081$ & $5.69952 \mathrm{e}-088$ \\
\hline Teste de Hausman (p-valor) & 0.33759 & 0.775176 & 0.830117 & 0.844715 \\
\hline $\begin{array}{c}\text { Normalidade dos Resíduos } \\
\text { (p-valor) }\end{array}$ & 0.46139 & 0.00000 & 0.01154 & 0.00000 \\
\hline Número de Estados & 27 & 27 & 27 & 27 \\
\hline Número de Observações & 432 & 432 & 432 & 432 \\
\hline
\end{tabular}

Fonte: Elaborado pelo autor

Nota: $* * *$ Significativo a $1 \% ; * *$ Significativo a $5 \% ; *$ Significativo a $10 \%$. 
Tabela 30 - Resultados da regressão tobit em Painel: impostos progressivos estaduais 2001-2012

\begin{tabular}{ccccc}
\hline Variáveis & Gini & Theil-T & P10-40 & P20-20 \\
\hline Constante & $0.553736^{* * *}$ & $0.618931^{* * *}$ & $18.3026^{* * *}$ & $20.4586^{* * *}$ \\
\hline IPVA/PIB & $-3.99235^{* * *}$ & $-8.73670^{* * *}$ & $-434.798^{* * *}$ & $-475.834 * * *$ \\
\hline ITCMD/PIB & $-51.3115^{* * *}$ & $-108.239^{* * *}$ & $-5619.55^{* * *}$ & $-7057.00^{* * *}$ \\
\hline RNE & $0.0344766^{* * *}$ & $0.131551^{* * *}$ & $3.30740^{* * *}$ & $3.28541^{* * *}$ \\
\hline RCO & $0.0377104^{* * *}$ & $0.0812102^{* * *}$ & $4.76372^{* * *}$ & $5.42299^{* * *}$ \\
\hline RSE & $0.0225116^{* * *}$ & $0.0523542^{* * *}$ & $2.37468^{* * *}$ & $2.61305^{* * *}$ \\
\hline RSU & $-0.0171750^{* *}$ & $-0.0489457^{*}$ & -0.536435 & -0.127142 \\
\hline ROYP/PIB & 0.114103 & $-3.35133^{*}$ & -40.6678 & -113.572 \\
\hline ROYSE/PIB & 6.13366 & $27.4836^{* *}$ & -149.437 & -848.223 \\
\hline $\begin{array}{c}\text { Normalidade dos Resíduos } \\
\text { (p-valor) }\end{array}$ & 0.790623 & 0.000382155 & $5.0383 \mathrm{e}-005$ & $5.13239 \mathrm{e}-007$ \\
\hline Número de Estados & 27 & 27 & 27 & 27 \\
\hline Número de Observações & 324 & 324 & 324 & 324 \\
\hline
\end{tabular}

Fonte: Elaborado pelo autor

Nota: ***Significativo a $1 \%$; **Significativo a $5 \%$; *Significativo a $10 \%$.

Observa-se nas Tabelas 29 e 30 que no âmbito dos impostos estaduais incidentes sobre a população dos estados, o IPVA e o ITCMD cumpriram seu papel progressivo à luz da função distributiva em todos os cenários no período de 2001 a 2012.

Quanto ao efeito regional, tomando por base o coeficiente de Theil-T, observa-se que no período em questão, 2001 a 2012, para cada ponto percentual acrescido ao coeficiente na região Norte, a região Nordeste aumentou 0,03\%, a região Centro-Oeste, $0,03 \%$, a região Sudeste, $0,02 \%$ e a região Sul diminui $0,017 \%$. Dessa forma, a região que mais conseguiu reduzir a desigualdade de renda nesse período neste cenário foi a região Sul.

Quanto ao diagnóstico do painel na Tabela 29, considerando os resultados dos testes de Chow e Breusch-Pagan, conclui-se que o modelo de dados em painel seria mais apropriado ao modelo pooled simples, nos quatro casos. Quanto ao teste de Hausman, verifica-se que o painel de efeitos aleatórios teria preferência sobre o painel de efeitos fixos em todos os cenários.

Os resultados dos royalties do petróleo e dos royalties do setor elétrico foram de modo geral inconclusivos. 
4.2.3 Impacto dos Impostos Progressivos Federais

As Tabelas 31 e 32 contêm os resultados dos testes aplicados utilizando-se respectivamente: regressão de dados em painel com efeitos aleatórios e regressão tobit em painel.

Tabela 31 - Resultados da regressão de dados em painel com efeitos aleatórios: impostos progressivos federais 2001-2012

\begin{tabular}{|c|c|c|c|c|}
\hline Variáveis & Gini & Theil-T & P10-40 & P20-20 \\
\hline Constante & $0.529355 * * *$ & $0.564169 * * *$ & $15.5221 * * *$ & $17.2887 * * *$ \\
\hline IR/PIB & 0.107976 & 0.350870 & 17.1738 & 20.8280 \\
\hline ITR/PIB & $7.49186 * *$ & 20.6814 & 626.145 & 430.157 \\
\hline RNE & $0.0312359 * * *$ & $0.121165^{* * *}$ & $2.91171 * *$ & $2.80893 * *$ \\
\hline $\mathrm{RCO}$ & -0.00464028 & -0.0141495 & -0.0939095 & -0.274560 \\
\hline RSE & -0.00584896 & -0.0167980 & -0.834275 & -1.28878 \\
\hline RSU & $-0.0482129 * * *$ & $-0.110432 * * *$ & $-4.05332 * *$ & $-4.49216^{* *}$ \\
\hline ROYP/PIB & -0.899542 & -3.44117 & -131.471 & -241.976 \\
\hline ROYSE/PIB & $14.4940 *$ & 31.5520 & 950.683 & 746.075 \\
\hline Pooled Simples & Não & Não & Não & Não \\
\hline Efeitos Fixos & Não & Não & Não & Não \\
\hline Efeitos Aleatórios & Sim & Sim & Sim & Sim \\
\hline $\begin{array}{l}\text { Teste de Breusch-Pagan } \\
\text { (p-valor) }\end{array}$ & $1.10527 \mathrm{e}-010$ & 0.000681788 & $6.54559 \mathrm{e}-012$ & $5.41179 \mathrm{e}-014$ \\
\hline $\begin{array}{l}\text { Teste de Hausman } \\
\text { (p-valor) }\end{array}$ & $2.72344 \mathrm{e}-020$ & $1.90081 \mathrm{e}-008$ & $2.15178 \mathrm{e}-024$ & $1.69929 \mathrm{e}-024$ \\
\hline $\begin{array}{l}\text { Normalidade dos Resíduos } \\
\text { (p-valor) }\end{array}$ & 0.39120 & 0.00000 & 0.00000 & 0.00000 \\
\hline Número de Estados & 27 & 27 & 27 & 27 \\
\hline Número de Observações & 324 & 324 & 324 & 324 \\
\hline
\end{tabular}

Fonte: Elaborado pelo autor

Nota: $* * *$ Significativo a $1 \% ; * *$ Significativo a $5 \% ; *$ Significativo a $10 \%$.

Tabela 32 - Resultados da regressão tobit em Painel: impostos progressivos federais 2001-2012

\begin{tabular}{ccccc}
\hline Variáveis & Gini & Theil-T & P10-40 & P20-20 \\
\hline Constante & $0.524109 * * *$ & $0.558942 * * *$ & $14.8706 * * *$ & $16.4904 * * *$ \\
\hline IR/PIB & $0.401507 * * *$ & $0.675529 * * *$ & $52.8160 * * *$ & $66.4443 * * *$ \\
\hline ITR/PIB & $7.25707 *$ & $19.1717 *$ & 587.032 & 348.010 \\
\hline RNE & $0.0295745^{* * *}$ & $0.117328^{* * *}$ & $2.78072 * * *$ & $2.62871 * * *$ \\
\hline RCO & $-0.0142404 * *$ & -0.0236921 & -1.17174 & $-1.61551^{*}$ \\
\hline RSE & $-0.0195310 * * *$ & $-0.0313559^{*}$ & $-2.54528 * * *$ & $-3.48393 * *$ \\
\hline RSU & $-0.0482568^{* * *}$ & $-0.111129 * * *$ & $-4.13732^{* * *}$ & $-4.56026^{* * *}$ \\
\hline ROYP/PIB & -0.423725 & -3.67963 & -117.394 & $-223.020^{* *}$ \\
\hline ROYSE/PIB & 6.03386 & $23.0216 *$ & 80.2785 & -470.875 \\
\hline $\begin{array}{c}\text { Normalidade dos Resíduos } \\
\text { (p-valor) }\end{array}$ & 0.363727 & 0.00148347 & $1.65987 \mathrm{e}-009$ & $8.74884 \mathrm{e}-016$ \\
\hline Número de Estados & 27 & 27 & 27 & 27 \\
\hline Número de Observações & 324 & 324 & 324 & 324 \\
\hline
\end{tabular}

Fonte: Elaborado pelo autor

Nota: $* * *$ Significativo a $1 \% ; * *$ Significativo a $5 \% ; *$ Significativo a $10 \%$. 
Observa-se nas Tabelas 31 e 32 que no âmbito dos impostos federais incidentes sobre a população dos estados, o IR e o ITR deixaram de cumprir seu papel progressivo à luz da função distributiva em todos os cenários no período de 2001 a 2012, em que pese os resultados inconclusivos quanto à significância estatística na Tabela 31 (apenas um resultado foi significativo).

Quanto ao diagnóstico do painel na Tabela 31, nos quatro casos, considerando os resultados dos testes de Chow e Breusch-Pagan, conclui-se que o modelo de dados em painel seria mais apropriado ao modelo pooled simples.

Quanto ao teste de Hausman, verifica-se que o painel de efeitos fixos teria preferência sobre o painel de efeitos aleatórios em todos os cenários. Porém, o uso do modelo com efetivos fixos seria inadequado para variáveis explicativas fixas ao longo do tempo, como é o caso desse estudo para as variáveis dummies: RNE, RCO, RSE e RSU.

Os resultados dos royalties do petróleo e dos royalties do setor elétrico foram de modo geral inconclusivos.

O efeito regional da região Sul foi mais uma vez negativo e significativo estatisticamente perante a região Norte, indicando que aquela região reduziu a desigualdade de renda em maior intensidade que essa região.

\subsubsection{Impacto Simultâneo dos Impostos Progressivos}

As Tabelas 33 e 35 contêm os resultados dos testes aplicados no período de 2001 a 2012 utilizando respectivamente: regressão de dados em painel com efeitos aleatórios e regressão tobit em painel; enquanto as Tabelas 34 e 36 contêm os resultados dos testes aplicados no período de 1995 a 2012 utilizando respectivamente: regressão de dados em painel com efeitos aleatórios e regressão tobit em painel.

Considerando o efeito simultâneo das variáveis explicativas, observa-se em todos os cenários tanto de 2001 a 2012, quanto de 1995 a 2012, que o ITBI, o ITCMD e o IPVA apresentaram relação inversa e significativa em relação aos indicadores de desigualdade de renda. Esse resultado mostra que a técnica de ajuste não alterou a essência dos sinais do modelo.

O IR e o ITR que são de competência federal obtiveram sinal inverso evidenciando que deixaram de cumprir seu papel progressivo à luz da função distributiva tanto no cenário de 2001 a 2012, quanto no cenário ajustado de 1995 a 2012. O resultado do IPTU foi inconclusivo. 
Tabela 33 - Resultados da regressão de dados em painel com efeitos aleatórios: impostos progressivos de todas as esferas 2001-2012

\begin{tabular}{|c|c|c|c|c|}
\hline Variáveis & Gini & Theil-T & P10-40 & P20-20 \\
\hline Constante & $0.553642 * * *$ & $0.615399 * * *$ & $18.0606^{* * *}$ & $20.0014 * * *$ \\
\hline Imposto de Renda /PIB & 0.127802 & 0.290313 & $21.1101 *$ & $27.2860 *$ \\
\hline ITR/PIB & $7.17868 * *$ & $22.1431 *$ & 560.213 & 357.716 \\
\hline IPVA/PIB & $-3.23507 * * *$ & $-6.88126 * *$ & $-356.848 * * *$ & $-406.390 * * *$ \\
\hline ITCMD/PIB & $-41.7499 * * *$ & $-71.1435^{*}$ & $-3438.28 * *$ & $-4561.95 * * *$ \\
\hline IPTU/PIB & 3.70365 & 6.01092 & 364.158 & 423.029 \\
\hline ITBI/PIB & $-30.7195 * * *$ & $-66.8289 * * *$ & $-3219.24 * * *$ & $-3241.16^{* * *}$ \\
\hline RNE & $0.0458227 * * *$ & $0.152401^{* * *}$ & $4.38105^{* * *}$ & $4.33602 * * *$ \\
\hline $\mathrm{RCO}$ & $0.0464187 * * *$ & $0.0910101 * *$ & $4.94864 * * *$ & $5.22365 * * *$ \\
\hline RSE & $0.0253792^{*}$ & 0.0547747 & 2.00908 & 1.75830 \\
\hline RSU & -0.00699398 & -0.0254661 & 0.0297858 & -0.0256377 \\
\hline ROYP/PIB & -0.858644 & -1.97030 & -134.279 & -244.768 \\
\hline ROYSE/PIB & 10.0207 & 32.5253 & 370.823 & 74.1626 \\
\hline Pooled Simples & Não & Não & Não & Não \\
\hline Efeitos Fixos & Não & Não & Não & Não \\
\hline Efeitos Aleatórios & Sim & Sim & Sim & Sim \\
\hline $\begin{array}{l}\text { Teste de Breusch-Pagan } \\
\text { (p-valor) }\end{array}$ & $6.85517 \mathrm{e}-031$ & $5.35364 \mathrm{e}-007$ & $1.29541 \mathrm{e}-026$ & $7.13989 \mathrm{e}-023$ \\
\hline $\begin{array}{l}\text { Teste de Hausman } \\
\text { (p-valor) }\end{array}$ & $4.83268 \mathrm{e}-006$ & 0.0345749 & $9.55512 \mathrm{e}-008$ & $1.87823 \mathrm{e}-008$ \\
\hline $\begin{array}{l}\text { Normalidade dos Resíduos } \\
\text { (p-valor) }\end{array}$ & 0.24039 & 0.00000 & 0.02586 & 0.00000 \\
\hline Número de Estados & 27 & 27 & 27 & 27 \\
\hline Número de Observações & 324 & 324 & 324 & 324 \\
\hline
\end{tabular}

Fonte: Elaborado pelo autor

Nota: ***Significativo a $1 \%$; **Significativo a $5 \%$; *Significativo a $10 \%$.

Tabela 34 - Resultados da regressão de dados em painel com efeitos aleatórios: impostos progressivos de todas as esferas 1995-2012

\begin{tabular}{|c|c|c|c|c|}
\hline Variáveis & Gini & Theil-T & P10-40 & P20-20 \\
\hline Constante & $0.561721 * * *$ & $0.645638 * * *$ & $19.1493 * * *$ & $21.4443 * * *$ \\
\hline Imposto de Renda /PIB & $0.175913^{* *}$ & 0.185320 & $20.6507 * *$ & $22.5693 * *$ \\
\hline ITR/PIB & $11.6515 * *$ & $34.1268 * * *$ & $1006.51 * * *$ & $819.367 *$ \\
\hline IPVA/PIB & $-4.57219 * * *$ & $-10.8918^{* * *}$ & $-499.297 * * *$ & $-544.313 * * *$ \\
\hline ITCMD/PIB & $-35.4996 * * *$ & $-74.1362 * *$ & $-2949.06^{* * *}$ & $-3974.80 * * *$ \\
\hline IPTU/PIB & $4.52527 *$ & 11.2476 & $450.780 *$ & $557.247 *$ \\
\hline ITBI/PIB & $-32.5622 * * *$ & $-69.8632 * * *$ & $-3494.57 * * *$ & $-3655.34 * * *$ \\
\hline RNE & $0.0481355 * * *$ & $0.155492 * * *$ & $4.82567 * * *$ & $4.23315^{* * *}$ \\
\hline $\mathrm{RCO}$ & $0.0449271 * * *$ & $0.0952989 * *$ & $5.00400 * * *$ & $5.20326 * *$ \\
\hline RSE & 0.0179502 & 0.0404487 & 1.44009 & 0.955909 \\
\hline RSU & 0.00186932 & -0.00694289 & 0.643047 & 0.556722 \\
\hline ROYP/PIB & $-2.05422 *$ & $-6.06343^{*}$ & $-267.120 * *$ & $-244.818^{*}$ \\
\hline ROYSE/PIB & -6.11696 & -14.0616 & $-1119.85 * *$ & $-1513.26 * *$ \\
\hline Pooled Simples & Não & Não & Não & Não \\
\hline Efeitos Fixos & Não & Não & Não & Não \\
\hline Efeitos Aleatórios & Sim & Sim & Sim & Sim \\
\hline $\begin{array}{l}\text { Teste de Breusch-Pagan } \\
\text { (p-valor) }\end{array}$ & $1.41831 \mathrm{e}-057$ & $8.18047 \mathrm{e}-026$ & $2.07011 \mathrm{e}-057$ & $1.00013 \mathrm{e}-047$ \\
\hline $\begin{array}{l}\text { Teste de Hausman } \\
\text { (p-valor) }\end{array}$ & 0.000436409 & 0.000434515 & 0.00128598 & 0.00678815 \\
\hline $\begin{array}{l}\text { Normalidade dos Resíduos } \\
\text { (p-valor) }\end{array}$ & 0.00000 & 0.00000 & 0.00012 & 0.00000 \\
\hline Número de Estados & 27 & 27 & 27 & 27 \\
\hline Número de Observações & 486 & 486 & 486 & 486 \\
\hline
\end{tabular}

Fonte: Elaborado pelo autor

Nota: $* * *$ Significativo a $1 \% ; * *$ Significativo a $5 \% ; *$ Significativo a $10 \%$. 
Tabela 35 - Resultados da regressão tobit em Painel: impostos progressivos de todas as esferas 20012012

\begin{tabular}{ccccc}
\hline Variáveis & Gini & Theil-T & P10-40 & P20-20 \\
\hline Constante & $0.541893^{* * *}$ & $0.599570^{* * *}$ & $16.8210^{* * *}$ & $18.7158^{* * *}$ \\
\hline Imposto de Renda /PIB & $0.351988^{* * *}$ & $0.571019^{* * *}$ & $48.6996^{* * *}$ & $62.1514 * * *$ \\
\hline ITR/PIB & $10.3155^{* * *}$ & $25.2258^{* *}$ & $893.297 * *$ & $729.439^{*}$ \\
\hline IPVA/PIB & $-2.62379^{* * *}$ & $-5.88629 * * *$ & $-273.982 * * *$ & $-283.732^{* *}$ \\
\hline ITCMD/PIB & $-26.6475^{* *}$ & -55.5136 & $-2386.50 * *$ & $-2820.47 * *$ \\
\hline IPTU/PIB & 1.01053 & 1.43034 & -0.462362 & -52.2907 \\
\hline ITBI/PIB & $-22.7599^{* * *}$ & $-50.6350^{* * *}$ & $-2498.69 * * *$ & $-3026.49 * * *$ \\
\hline RNE & $0.0417169^{* * *}$ & $0.148384 * *$ & $4.17799^{* * *}$ & $4.34763 * * *$ \\
\hline RCO & $0.0219911^{* * *}$ & $0.0572702 * *$ & $2.74470^{* * *}$ & $3.09818^{* * *}$ \\
\hline RSE & $0.0122773 *$ & $0.0451434 *$ & 1.01538 & 0.858494 \\
\hline RSU & $-0.0171584 * *$ & $-0.0414224 *$ & -0.697216 & -0.394929 \\
\hline ROYP/PIB & 0.540904 & -2.02009 & -17.4969 & -97.6053 \\
\hline ROYSE/PIB & $12.5144 * * *$ & $37.2032 * * *$ & $807.638 *$ & 434.697 \\
\hline Normalidade dos Resíduos & 0.166334 & $9.54011 \mathrm{e}-006$ & 0.00222211 & $1.67017 \mathrm{e}-005$ \\
\hline p-valor) & 27 & 27 & 27 & 27 \\
\hline Número de Estados & 324 & 324 & 324 & 324 \\
\hline Número de Observações & & & & \\
\hline
\end{tabular}

Fonte: Elaborado pelo autor

Nota: ***Significativo a $1 \% ; * *$ Significativo a $5 \%$; *Significativo a $10 \%$.

Tabela 36 - Resultados da regressão tobit em Painel: impostos progressivos de todas as esferas 19952012

\begin{tabular}{ccccc}
\hline Variáveis & Gini & Theil-T & P10-40 & P20-20 \\
\hline Constante & $0.551348^{* * *}$ & $0.621704^{* * *}$ & $17.9805^{* * *}$ & $20.2102^{* * *}$ \\
\hline Imposto de Renda /PIB & $0.286387^{* * *}$ & $0.396792^{* * *}$ & $41.6557^{* * *}$ & $53.6297 * *$ \\
\hline ITR/PIB & $17.5025^{* * *}$ & $48.8976^{* * *}$ & $1623.80^{* * *}$ & $1587.91^{* * *}$ \\
\hline IPVA/PIB & $-4.21392^{* * *}$ & $-10.0301^{* * *}$ & $-448.089^{* * *}$ & $-456.989^{* * *}$ \\
\hline ITCMD/PIB & $-47.1679^{* * *}$ & $-108.601 * * *$ & $-4820.82^{* * *}$ & $-5748.26^{* * *}$ \\
\hline IPTU/PIB & 1.68929 & 4.11658 & 55.2427 & 11.3083 \\
\hline ITBI/PIB & $-16.1829 * * *$ & $-27.2381^{*}$ & $-1779.94 * * *$ & $-2250.80^{* * *}$ \\
\hline RNE & $0.0453666^{* * *}$ & $0.150958^{* * *}$ & $4.70368^{* * *}$ & $4.48862^{* * *}$ \\
\hline RCO & $0.0198318 * * *$ & $0.0383297 *$ & $2.44638^{* * *}$ & $2.66160^{* * *}$ \\
\hline RSE & $0.0222228 * * *$ & $0.0472439 * * *$ & $2.06005 * * *$ & $1.93509 * *$ \\
\hline RSU & -0.00762208 & -0.0315077 & -0.0760711 & 0.265571 \\
\hline ROYP/PIB & -1.14498 & $-6.34446 * *$ & $-207.114 * *$ & $-278.897 * * *$ \\
\hline ROYSE/PIB & 6.29549 & 19.0138 & 224.320 & -236.972 \\
\hline $\begin{array}{c}\text { Normalidade dos Resíduos } \\
\text { (p-valor) }\end{array}$ & 0.00118721 & 0.0272773 & 0.000839054 & $4.03833 \mathrm{e}-007$ \\
\hline Número de Estados & 27 & 27 & 27 & 27 \\
\hline Número de Observações & 486 & 486 & 486 & 486 \\
\hline
\end{tabular}

Fonte: Elaborado pelo autor

Nota: $* * *$ Significativo a $1 \% ; * *$ Significativo a $5 \%$; $*$ Significativo a $10 \%$.

Tais resultados vão contra os resultados anteriores de estudos internacionais de Perroti (1996), Partridge (1997), Figini (1998), Panizza (1999). Uma possível explicação é que o modelo do sistema tributário brasileiro por estar concentrado mais em consumo e menos em renda, contribui para o agravamento da desigualdade com os impostos federais: IR e ITR. 
Quanto ao diagnóstico do painel nas Tabelas 11 e 12, nos quatro casos, considerando os resultados dos testes de Chow e Breusch-Pagan, conclui-se que o modelo de dados em painel seria mais apropriado ao modelo pooled simples.

Quanto ao teste de Hausman, verifica-se que o painel de efeitos fixos teria preferência sobre o painel de efeitos aleatórios em todos os cenários, ressalvado o cenário de 2001-2012 que tem como variável dependente coeficiente de Gini.

Porém, o uso do modelo com efetivos fixos seria inadequado para variáveis explicativas fixas ao longo do tempo, como é o caso desse estudo para as variáveis dummies: RNE, RCO, RSE e RSU. Assim, foi utilizado o modelo com efeitos aleatórios.

Em quase todos os cenários, o resultado dos Royalties do Petróleo apresentou relação inversa aos indicadores de desigualdade, sendo geralmente significativo e confirmando o esperado na pesquisa; enquanto o sinal dos Royalties do setor elétrico foi inconclusivo.

O efeito regional foi geralmente conclusivo, em ambos os métodos e cenários temporais, para as Regiões Nordeste e Centro-Oeste. Neste caso, a Região Norte a exemplo de resultados anteriores reduziu a desigualdade de renda de forma mais intensa que estas duas regiões. 


\subsection{Resultados da Hipótese 3}

As Tabelas 37 e 38 contêm os resultados dos testes aplicados utilizando-se respectivamente: regressão de dados em painel com efeitos aleatórios e regressão tobit em painel. Considerando as limitações expostas na Tabela 11 foi considerado o período de 2004 a 2012.

Tabela 37 - Resultados da regressão de dados em painel com efeitos aleatórios: transferências de renda diretas 2004-2012

\begin{tabular}{|c|c|c|c|c|}
\hline Variáveis & Gini & Theil-T & P10-40 & P20-20 \\
\hline Constante & $0.589515^{* * *}$ & $0.671548 * * *$ & $21.5238 * * *$ & $22.9305^{* * *}$ \\
\hline Bolsa Família/PIB & $49.9113 * * *$ & $158.121 * * *$ & $4799.83 * * *$ & $5031.65^{* * *}$ \\
\hline BPC Idoso/PIB & $-106.495 * * *$ & $-213.462 * *$ & $-10012.1 * * *$ & $-7060.97 *$ \\
\hline BPC Deficiente/PIB & $-135.138 * * *$ & $-333.625 * * *$ & $-13304.2 * * *$ & $-14878.9 * * *$ \\
\hline RNE & $0.0397633 * * *$ & $0.105958 * * *$ & $3.63805 * *$ & $3.41309 *$ \\
\hline $\mathrm{RCO}$ & -0.0175590 & -0.0102672 & -1.46416 & -1.94666 \\
\hline RSE & $-0.0368032 * *$ & $-0.0696594 * *$ & $-3.42810 * *$ & $-3.68220 *$ \\
\hline$\overline{R S U}$ & $-0.0951941 * * *$ & $-0.186757 * * *$ & $-8.31382 * * *$ & $-8.32527 * * *$ \\
\hline Royalties Petróleo/PIB & $-3.93831 * *$ & -5.11180 & $-384.217 * *$ & $-436.751 * *$ \\
\hline $\begin{array}{l}\text { Royalties Setor } \\
\text { Elétrico/PIB }\end{array}$ & $29.7412 * * *$ & $66.5032 * *$ & $2195.77 * *$ & 1435.02 \\
\hline Pooled Simples & Não & Não & Não & Não \\
\hline Efeitos Fixos & Não & Não & Não & Não \\
\hline Efeitos Aleatórios & Sim & Sim & Sim & Sim \\
\hline $\begin{array}{l}\text { Teste de Breusch- } \\
\text { Pagan (p-valor) }\end{array}$ & $2.02846 \mathrm{e}-042$ & $1.57116 \mathrm{e}-007$ & $4.90459 \mathrm{e}-054$ & $4.00908 \mathrm{e}-057$ \\
\hline $\begin{array}{l}\text { Teste de Hausman } \\
\text { (p-valor) }\end{array}$ & 0.0152147 & $5.53193 \mathrm{e}-005$ & 0.0803142 & 0.22048 \\
\hline $\begin{array}{l}\text { Normalidade dos } \\
\text { Resíduos (p-valor) }\end{array}$ & 0.15515 & 0.00000 & 0.00000 & 0.00000 \\
\hline Número de Estados & 27 & 27 & 27 & 27 \\
\hline $\begin{array}{c}\text { Número de } \\
\text { Observações }\end{array}$ & 243 & 243 & 243 & 243 \\
\hline
\end{tabular}

Fonte: Elaborado pelo autor

Nota: ***Significativo a $1 \%$; **Significativo a $5 \%$; *Significativo a $10 \%$.

Tabela 38 - Resultados da regressão tobit em Painel: transferências de renda diretas 2004-2012

\begin{tabular}{ccccc}
\hline Variáveis & Gini & Theil-T & P10-40 & P20-20 \\
\hline Constante & $0.562063^{* * *}$ & $0.610675^{* * *}$ & $19.0763 * * *$ & $20.6760^{* * *}$ \\
\hline Bolsa Família/PIB & $18.5482^{*}$ & $99.9719^{* * *}$ & $1914.82^{*}$ & $2390.04^{*}$ \\
\hline BPC Idoso/PIB & $-83.2536^{* * *}$ & $-147.543^{* *}$ & $-9028.48^{* * *}$ & $-7297.07^{* * *}$ \\
\hline BPC Deficiente/PIB & $-35.6317^{*}$ & $-146.171^{* *}$ & -3324.89 & $-4495.62^{*}$ \\
\hline RNE & $0.0316197^{* * *}$ & $0.0915161^{* * *}$ & $2.87018^{* * *}$ & $2.44193^{* *}$ \\
\hline RCO & 0.000992825 & 0.0233917 & 0.739230 & 0.660295 \\
\hline RSE & $-0.0261896^{* * *}$ & $-0.0391717^{*}$ & $-2.72983^{* * *}$ & $-3.23753^{* * *}$ \\
\hline RSU & $-0.0671071^{* *}$ & $-0.131301^{* * *}$ & $-5.71405^{* * *}$ & $-5.61627^{* * *}$ \\
\hline Royalties Petróleo/PIB & -0.950722 & -1.75822 & -158.947 & -202.980 \\
\hline Royalties Setor Elétrico/PIB & 5.64521 & 28.9384 & -180.297 & $-1444.48 *$ \\
\hline $\begin{array}{c}\text { Normalidade dos Resíduos } \\
\text { (p-valor) }\end{array}$ & 0.0527075 & $1.98036 \mathrm{e}-010$ & $2.26321 \mathrm{e}-009$ & $8.89399 \mathrm{e}-$ \\
\hline Número de Estados & 27 & 27 & 27 & 27 \\
\hline Número de Observações & 243 & 243 & 243 & 243 \\
\hline Fonte & & & & 27 \\
\hline
\end{tabular}

Fonte: Elaborado pelo autor

Nota: $* * *$ Significativo a $1 \% ; * *$ Significativo a $5 \%$; $*$ Significativo a $10 \%$. 
Observa-se nas Tabelas 37 e 38 que no âmbito das transferências de renda diretas proporcionais ao PIB Estadual ambos os Benefícios de Prestação Continuada (BPC) apresentaram sinal inverso aos quatro indicadores de desigualdade de renda, sendo que o BPC deficiente não foi significativo em relação as variáveis dependentes: P10-40.

O Bolsa Família apresentou sinal positivo e significativo, contrariando os resultados evidenciados nos estudos de Rocha (2008), Hoffmann (2010), Cavalcanti, Costa e Silva (2013), Araújo, Alves e Bessaria (2013) e Peña et alli (2015).

No entanto, os resultados aqui evidenciados reforçam os estudos de Marinho, Linhares e Campelo (2011), Lima, Moreira e Souza (2013), Lima e Moreira (2014) de que as transferências de renda direta do bolsa família foram ineficientes da redução da desigualdade de renda.

O efeito regional foi significativo na Região Sul, Região Sudeste e Região Nordeste em relação a Região Norte. Mais uma vez em termos de desigualdade a Região Sul superou a Região Norte, e a região Norte superou a Nordeste. A região Sudeste que nos resultados anteriores não esteve em evidencia, obteve neste cenário desempenho superior a região Norte.

Os royalties do Petróleo apresentaram sinal negativo e significativo em todos os cenários da regressão de dados em painel com efeitos aleatórios alinhando-se com a expectativa de redução da desigualdade de renda, enquanto os royalties do Setor Elétrico apresentaram sinal positivo contrariando a expectativa.

Quanto ao diagnóstico do painel, nos quatro casos, considerando os resultados dos testes de Chow e Breusch-Pagan, conclui-se que o modelo de dados em painel seria mais apropriado ao modelo pooled simples. Quanto ao teste de Hausman, verifica-se que o painel de efeitos aleatórios teria preferência sobre o painel de efeitos fixos quando a variável dependente foi P10-40 ou P20-20.

\subsection{Resultados da Hipótese 4}

Nesta seção será iniciada a apresentação dos resultados considerando o fator eficiência como variável independente ou explicativa. Para tanto foi utilizada uma abordagem semiparamétrica em dois estágios. No $1^{\text {o }}$ estágio foram calculados para cada ano, de 1995 a 2012, os escores de eficiência (benchmarkings de referência). 
No $2^{\circ}$ estágio, esses benchmarkings foram introduzidos no modelo. Os Quadros 28 e 29 contêm o desempenho dos Estados para as áreas de saúde e educação respectivamente.

Considerando as variáveis dos inputs e dos outputs em saúde, os Estados com melhor desempenho de modo geral foram: Rio de Janeiro e Maranhão. Ou seja, considerando como inputs os valores gastos em saúde, estes foram os Estados mais eficientes em “ofertar" leitos públicos e médicos. O Estado de São Paulo, apesar de possuir mais leitos e mais médicos, foi aproximadamente $50 \%$ menos eficiente que ambos em 2012. Ressalta-se que não foram consideradas quaisquer outras variáveis como salários, estrutura hospitalar (equipamentos, salas, energia e água), distribuição espacial dos médicos no território estadual, que podem afetar o atendimento ao cidadão.

Considerando as variáveis dos inputs e dos outputs em educação, os Estados com melhores desempenhos foram: Minas Gerais, Pernambuco, Rio Grande do Sul. Ou seja, considerando como inputs os valores gastos em educação, estes foram os Estados mais eficientes "ofertar" professores e matrículas. O Estado de São Paulo apesar de possuir mais matrículas e mais professores, foi 49\% menos eficiente que esses Estados em 2012.

Ressalta-se que não foram consideradas quaisquer outras variáveis como salários e estrutura escolar (equipamentos, salas, energia e água) que podem afetar o atendimento ao aluno. 
Quadro 29 - Benchmarkings de saúde resultantes da análise envoltória de dados (DEA) aplicados na hipótese 4 - modelo CCR

\begin{tabular}{|c|c|c|c|c|c|c|c|c|c|c|c|c|c|c|c|c|c|c|}
\hline Estado & 1995 & 1996 & 1997 & 1998 & 1999 & 2000 & 2001 & 2002 & 2003 & 2004 & 2005 & 2006 & 2007 & 2008 & 2009 & 2010 & 2011 & 2012 \\
\hline Amapá & 0.197 & 0.141 & 0.092 & 0.114 & 0.045 & 0.045 & 0.195 & 0.199 & 0.162 & 0.112 & 0.160 & 0.165 & 0.109 & 0.171 & 0.204 & 0.238 & 0.230 & 0.220 \\
\hline Amazonas & 0.238 & 0.205 & 0.094 & 0.101 & 0.140 & 0.140 & 0.224 & 0.188 & 0.201 & 0.147 & 0.170 & 0.200 & 0.184 & 226 & 0.251 & 281 & & \\
\hline Ceará & 0.292 & 0.580 & 0.142 & 0.312 & 0.213 & 0.213 & 0.452 & 0.372 & 0.442 & 0.455 & 0.655 & 0.683 & 0.707 & 0.836 & 0.806 & 0.840 & 0.824 & 0.816 \\
\hline Distrito Federal & 0.052 & 0.051 & 0.040 & 0.080 & 0.061 & 0.061 & 0.223 & 0.126 & 0.322 & 0.349 & 0.350 & 0.352 & 0.257 & 0.312 & 0.471 & 0.317 & 0.302 & 0.288 \\
\hline Espírito Santo & 0.098 & 0.097 & 0.063 & 0.153 & 0.140 & 0.140 & 0.482 & 0.420 & 0.476 & 0.503 & 0.436 & 0.463 & 0.402 & 0.412 & 0.471 & 0.400 & 0.424 & 0.443 \\
\hline Goiás & 0.697 & 0.555 & 0.301 & 0.276 & 0.285 & 0.285 & 0.506 & 0.462 & 0.547 & 0.368 & 0.503 & 0.575 & 0.484 & 0.591 & 0.679 & 0.696 & 0.710 & 0.667 \\
\hline Mato Grosso do St & 0.513 & 0.393 & 0.268 & 0.481 & 0.160 & 0.160 & 0.573 & 0.405 & 0.415 & 0.427 & 0.522 & 0.580 & 0.449 & 0.453 & 0.526 & 0.504 & 0.539 & 0.695 \\
\hline Minas Gerais & 0.125 & 0.206 & 0.180 & 1.000 & 0.199 & 0.199 & 0.548 & 0.438 & 0.567 & 0.572 & 0.717 & 0.828 & 0.666 & 0.672 & 0.783 & 0.708 & 0.752 & 0.682 \\
\hline Pará & 0.161 & 0.156 & 0.092 & 0.131 & 0.111 & 0.111 & 0.409 & 0.309 & 0.349 & 0.316 & 0.408 & 0.389 & 0.416 & 0.501 & 0.649 & 0.645 & 0.762 & 0.630 \\
\hline Paraíba & 0.873 & 0.669 & 0.295 & 0.403 & 0.201 & 0.201 & 0.443 & 0.492 & 0.679 & 0.596 & 0.682 & 0.792 & 0.639 & 0.754 & 0.686 & 0.859 & 0.894 & 0.942 \\
\hline Paraná & 0.333 & 0.259 & 0.167 & 0.302 & 0.195 & 0.195 & 0.661 & 0.420 & 0.527 & 0.562 & 0.660 & 0.670 & 0.577 & 0.670 & 0.840 & 0.798 & 0.799 & 0.846 \\
\hline Pernambuc & 0.525 & 0.482 & 0.261 & 0.464 & 0.706 & 0.706 & 0.702 & 0.545 & 0.638 & 0.473 & 0.486 & 0.540 & 0.467 & 0.517 & 0.511 & 0.571 & 0.546 & 0.561 \\
\hline Piauí & 0.144 & 0.150 & 0.194 & 0.221 & 0.125 & 0.125 & 0.705 & 0.708 & 0.617 & 0.679 & 0.529 & 0.579 & 0.530 & 0.399 & 0.645 & 0.839 & 0.828 & 1.000 \\
\hline Santa Catarina & 0.193 & 0.136 & 0.114 & 0.196 & 0.122 & 0.122 & 0.473 & 0.276 & 0.316 & 0.392 & 0.534 & 0.544 & 0.494 & 0.776 & 0.582 & 0.592 & 0.585 & 0.644 \\
\hline Paulo & 0.138 & .210 & 0.200 & 0.232 & 0.186 & 0.186 & 0.605 & 0.407 & 0.480 & 0.439 & 0.487 & 0.534 & 0.438 & 0.445 & 13 & 0.451 & 461 & 0.494 \\
\hline Sergipe & 0.142 & 0.133 & 0.063 & 0.082 & 0.104 & 0.104 & 0.364 & 0.245 & 0.242 & 0.297 & 0.415 & 0.407 & 0.349 & 0.388 & 0.438 & 0.431 & 0.431 & 0.438 \\
\hline Tocantins & 0.311 & 0.323 & 0.187 & 0.142 & 0.080 & 0.080 & 0.731 & 0.247 & 0.276 & 0.204 & 0.223 & 0.260 & 0.224 & 0.253 & 0.289 & 0.289 & 0.261 & 0.281 \\
\hline
\end{tabular}

Legenda: inputs - despesas estaduais na função saúde; outputs - médicos e leitos de internação do SUS. 
Quadro 30 - Benchmarkings de educacão resultantes da análise envoltória de dados aplicados na hipótese 4 - modelo CCR

\begin{tabular}{|c|c|c|c|c|c|c|c|c|c|c|c|c|c|c|c|c|c|c|}
\hline Estado & 1995 & 1996 & 1997 & 1998 & 1999 & 2000 & 2001 & 2002 & 2003 & 2004 & 2005 & 2006 & 2007 & 2008 & 2009 & 2010 & 2011 & 2012 \\
\hline Acre & 0.56 & 0.62 & 0.63 & 0.48 & 0.64 & 0.36 & 0.53 & 0.55 & 0.45 & 0.43 & 0.44 & 0.45 & 0.43 & 0.24 & 0.48 & 0.48 & 0.61 & 0.58 \\
\hline Alagoas & 0.49 & 0.54 & 0.56 & 0.57 & 0.50 & 0.42 & 0.46 & 0.48 & 0.39 & 1.00 & 0.75 & 0.74 & 0.75 & 0.38 & 0.82 & 0.72 & 0.79 & 0.62 \\
\hline Amapá & 0.27 & 0.45 & 0.62 & 0.59 & 0.52 & 0.38 & 0.46 & 0.49 & 1.00 & 0.41 & 0.53 & 0.46 & 0.52 & 0.24 & 0.49 & 0.47 & 0.54 & 0.52 \\
\hline Amazonas & 0.67 & 0.58 & 0.65 & 0.80 & 0.79 & 0.48 & 0.57 & 0.62 & 0.54 & 0.59 & 0.63 & 0.64 & 0.70 & 0.38 & 0.81 & 0.69 & 0.80 & 0.79 \\
\hline Bahia & 0.82 & 0.83 & 0.68 & 0.67 & 0.67 & 0.62 & 0.65 & 0.89 & 0.66 & 0.64 & 0.65 & 0.68 & 0.75 & 0.39 & 0.75 & 0.73 & 0.72 & 0.67 \\
\hline Ceará & 0.45 & 0.78 & 0.60 & 0.60 & 0.58 & 0.39 & 0.32 & 0.38 & 0.30 & 0.37 & 0.40 & 0.38 & 0.42 & 0.20 & 0.35 & 0.29 & 0.33 & 0.57 \\
\hline Distrito Federal & 0.26 & 0.31 & 0.27 & 0.38 & 0.19 & 0.23 & 0.31 & 0.35 & 0.40 & 0.52 & 0.56 & 0.51 & 0.58 & 0.19 & 0.36 & 0.35 & 0.39 & 0.40 \\
\hline Espírito Santo & 0.86 & 1.00 & 1.00 & 0.54 & 0.53 & 0.67 & 0.78 & 1.00 & 0.87 & 0.48 & 0.44 & 0.43 & 0.46 & 0.25 & 0.46 & 0.51 & 0.63 & 0.70 \\
\hline Goiás & 0.95 & 0.91 & 1.00 & 0.97 & 1.00 & 0.67 & 0.67 & 0.77 & 0.60 & 0.55 & 0.61 & 0.58 & 0.63 & 0.35 & 0.69 & 0.58 & 0.66 & 0.56 \\
\hline Maranhão & 0.73 & 0.75 & 0.93 & 1.00 & 0.85 & 0.86 & 0.53 & 0.55 & 0.46 & 0.92 & 0.91 & 0.86 & 0.95 & 0.48 & 0.86 & 0.79 & 0.82 & 0.72 \\
\hline Mato Grosso & 0.55 & 0.72 & 0.63 & 0.77 & 0.56 & 0.55 & 0.78 & 0.88 & 0.67 & 0.64 & 0.70 & 0.71 & 0.70 & 0.33 & 0.66 & 0.60 & 0.72 & 0.74 \\
\hline Mato Grossc & 0.65 & 0.61 & 0.89 & 0.61 & 0.54 & 0.29 & 0.49 & 0.93 & 0.67 & 0.54 & 0.76 & 0.69 & 0.61 & 0.28 & 0.54 & 0.65 & 0.62 & 0.56 \\
\hline Minas Gerais & 0.69 & 0.74 & 0.76 & 0.50 & 0.56 & 0.38 & 0.58 & 0.72 & 0.64 & 0.85 & 1.00 & 0.94 & 0.96 & 0.47 & 1.00 & 1.00 & 1.00 & 1.00 \\
\hline Pará & 0.92 & 0.89 & 1.00 & 0.75 & 0.85 & 0.64 & 0.66 & 0.78 & 0.70 & 0.86 & 1.00 & 0.96 & 1.00 & 0.46 & 0.87 & 0.81 & 0.88 & 0.79 \\
\hline Paraíba & 0.85 & 0.83 & 0.79 & 0.64 & 0.55 & 0.43 & 0.47 & 0.89 & 0.79 & 0.82 & 0.83 & 0.78 & 0.86 & 0.45 & 0.69 & 0.64 & 0.77 & 0.69 \\
\hline Paraná & 0.60 & 0.54 & 0.54 & 0.46 & 0.48 & 0.41 & 0.66 & 0.79 & 0.67 & 0.55 & 0.69 & 0.66 & 0.49 & 0.25 & 0.49 & 0.48 & 0.53 & 0.63 \\
\hline Pernambuc & 0.91 & 1.00 & 0.86 & 0.88 & 0.93 & 1.00 & 1.00 & 1.00 & 1.00 & 1.00 & 1.00 & 1.00 & 1.00 & 0.49 & 0.90 & 0.76 & 0.82 & 0.76 \\
\hline Piauí & 0.84 & 0.83 & 0.97 & 1.00 & 0.75 & 0.62 & 0.80 & 0.90 & 0.65 & 0.67 & 0.73 & 1.00 & 0.81 & 1.00 & 0.93 & 0.77 & 0.87 & 0.90 \\
\hline Rio de Jane & 0.30 & 0.32 & 0.42 & 0.29 & 0.21 & 0.15 & 0.34 & 0.49 & 0.26 & 0.32 & 0.46 & 0.35 & 0.30 & 0.16 & 0.37 & 0.34 & 0.39 & 0.38 \\
\hline Rio Grande do Norte & 1.00 & 0.82 & 0.76 & 0.52 & 0.50 & 1.00 & 0.40 & 0.67 & 0.53 & 0.61 & 0.58 & 0.55 & 0.57 & 0.33 & 0.63 & 0.60 & 0.68 & 0.52 \\
\hline Rio Grande do Sul & 1.00 & 0.64 & 0.88 & 0.79 & 0.75 & 0.30 & 0.71 & 0.59 & 0.51 & 0.55 & 1.00 & 0.94 & 1.00 & 0.30 & 0.56 & 0.51 & 0.60 & 0.60 \\
\hline Rondônia & 0.68 & 0.72 & 0.65 & 0.75 & 0.66 & 0.50 & 0.49 & 0.5 & 0.47 & 0.49 & 0.55 & 0.60 & 0. & 0.33 & 0.6 & 0.62 & 0.69 & 0.70 \\
\hline Roraima & 0.47 & 0.61 & 0.51 & 0.51 & 0.55 & 0.85 & 0.46 & 0.5 & 0.44 & 0.47 & 0.58 & 0.45 & 0.44 & 0.20 & 0.46 & 0.44 & 0.48 & 0.58 \\
\hline Santa Catarina & 0.79 & 0.80 & 0.76 & 0.86 & 0.98 & 0.43 & 0.60 & 0.62 & 0.50 & 0.48 & 0.55 & 0.57 & 0.79 & 0.36 & 0.72 & 0.73 & 0.80 & 0.71 \\
\hline São Paulo & 0.51 & 0.50 & 0.76 & 0.53 & 0.48 & 0.34 & 0.33 & 0.38 & 0.33 & 0.31 & 0.38 & 0.37 & 0.39 & 0.19 & 0.40 & 0.44 & 0.41 & 0.51 \\
\hline & 0.51 & 0.60 & 0.71 & 0.69 & 0.66 & 0.47 & 0.43 & 0.64 & 0.54 & 0.59 & 0.59 & 0.53 & 0.60 & 0.33 & 0.58 & 0.49 & 0.68 & 0.59 \\
\hline Tocantins & 0.82 & 0.86 & 0.82 & 0.88 & 0.83 & 0.52 & 0.50 & 0.58 & 0.47 & 0.54 & 0.64 & 0.66 & 0.71 & 0.32 & 0.66 & 0.67 & 0.73 & 0.67 \\
\hline
\end{tabular}

Legenda: inputs - despesas estaduais na função educação; outputs - quantidade de professores e matrículas no âmbito estadual dos seguintes períodos: creche, pré-escola, ensino fundamental e ensino médio 
Tabela 39 - Resultados da regressão dados painel com efeitos aleatórios: eficiência da função alocativa - ênfase nos produtos "ofertados" em saúde e educação

\begin{tabular}{ccccc}
\hline Variáveis & Gini & Theil-T & P10-40 & P20-20 \\
\hline Constante & $0.573017^{* * *}$ & $0.685373^{* * *}$ & $20.1197 * * *$ & $21.5973^{* * *}$ \\
\hline Benchmarking Saúde & $-0.0766905^{* * *}$ & $-0.182917^{* * *}$ & $-7.93148^{* * * *}$ & $-8.78660^{* * *}$ \\
\hline Benchmarking Educação & $0.0351963^{* * *}$ & $0.0945064^{* * *}$ & $3.85145^{* * *}$ & $5.31032^{*}$ \\
\hline RNE & $-0.000623144^{* * *}$ & -0.00859004 & -0.164168 & -0.469211 \\
\hline RCO & -0.00107794 & -0.00542202 & 0.0102243 & -0.612705 \\
\hline RSE & $3.26978 \mathrm{e}-05$ & 0.00230177 & 0.0277205 & -0.417188 \\
\hline RSU & -0.00235197 & -0.00439469 & -0.342820 & -0.497808 \\
\hline Royalties Petróleo/PIB & $-2.13677^{*}$ & -4.98454 & $-312.068^{* *}$ & $-292.521^{*}$ \\
\hline Royalties Setor Elétrico/PIB & $-18.0991^{* * *}$ & $-54.9178^{* * *}$ & $-2154.03^{* * *}$ & $-2435.01 * * *$ \\
\hline Pooled Simples & Não & Não & Não & Não \\
\hline Efeitos Fixos & Não & Não & Não & Não \\
\hline Efeitos Aleatórios & Sim & Sim & Sim & Sim \\
\hline Teste de Breusch-Pagan (p-valor) & $1.18167 \mathrm{e}-194$ & $1.74097 \mathrm{e}-157$ & $4.90459 \mathrm{e}-054$ & $2.05156 \mathrm{e}-022$ \\
\hline Teste de Hausman (p-valor) & 0.18316 & 0.0973475 & 0.0803142 & $8.4544 \mathrm{e}-058$ \\
\hline Normalidade dos Resíduos (p-valor) & 0.00890 & 0.00000 & 0.00000 & 0.00001 \\
\hline Número de Estados & 27 & 27 & 27 & 27 \\
\hline Número de Observações & 486 & 486 & 486 & 486 \\
\hline
\end{tabular}

Fonte: Elaborado pelo autor

Nota: $* * *$ Significativo a $1 \%$; **Significativo a $5 \%$; *Significativo a $10 \%$.

Tabela 40 - Resultados da regressão tobit em painel: eficiência da função alocativa - ênfase nos produtos “ofertados" em saúde e educação

\begin{tabular}{ccccc}
\hline Variáveis & Gini & Theil-T & P10-40 & P20-20 \\
\hline Constante & $0.555177^{* * *}$ & $0.596072^{* * *}$ & $19.0484^{* * *}$ & $21.7899^{* * *}$ \\
\hline Benchmarking Saúde & $-0.0291794^{* * * *}$ & -0.0299808 & $-3.47049^{* * *}$ & $-4.56625^{* * *}$ \\
\hline Benchmarking Educação & $0.0253331^{* * *}$ & $0.118582^{* * *}$ & $1.93709^{*}$ & 1.77542 \\
\hline RNE & 0.000174668 & -0.00973901 & -0.0263738 & -0.230678 \\
\hline RCO & -0.000408835 & -0.0110844 & 0.181546 & -0.254878 \\
\hline RSE & 0.00115061 & 0.00340027 & 0.176919 & -0.218202 \\
\hline RSU & -0.00269002 & -0.00599643 & -0.348362 & -0.504224 \\
\hline Royalties Petróleo/PIB & 0.867412 & 1.65788 & -23.5318 & -140.091 \\
\hline Royalties Setor Elétrico/PIB & -16.8363 & $-40.9238 * * *$ & $-2210.88^{* * *}$ & -2983.87 \\
\hline Normalidade dos Resíduos (p-valor) & $5.92234 \mathrm{e}-008$ & 0.058424 & $1.33865 \mathrm{e}-005$ & $2.79414 \mathrm{e}-012$ \\
\hline Número de Estados & 27 & 27 & 27 & 27 \\
\hline Número de Observações & 486 & 486 & 486 & 486 \\
\hline
\end{tabular}

Fonte: Elaborado pelo autor

Nota: $* * *$ Significativo a $1 \% ; * *$ Significativo a $5 \% ; *$ Significativo a $10 \%$.

Observa-se nas Tabelas 39 e 40 que os Estados mais eficientes em saúde reduziram a desigualdade de renda, enquanto que os Estados mais eficientes em educação agravaram o quadro de desigualdade de renda. Este último resultado foi tão controverso quanto o resultado obtido na hipótese 1.

Nesses dois cenários, considerando os dois modelos estatísticos, os Estados com maior proporção de royalties do petróleo reduziram a desigualdade de renda na Tabela 39, enquanto os Estados com maior proporção de royalties do setor elétrico reduziram a desigualdade de renda na Tabela 40 (ressalvada a falta de significância estatística para as variáveis dependentes Gini e P20-20). 


\subsection{Resultados da hipótese 5}

Tal qual na hipótese 4, a hipótese 5 também utilizou uma abordagem semiparamétrica em dois estágios. No $1^{\circ}$ estágio foram calculados para cada ano, de 1995 a 2012, os escores de eficiência (benchmarkings de referência) de saúde; e de 2005 a 2012, os escores de eficiência (benchmarkings de referência) de educação.

No $2^{\circ}$ estágio, esses benchmarkings foram introduzidos no modelo. Os Quadros 29 e 30 contêm o desempenho dos Estados para as áreas de saúde e educação respectivamente.

Considerando as variáveis dos inputs e dos outputs em saúde, os Estados com melhor desempenho em 2012 foram: Alagoas, Amapá, Pará e São Paulo. Ou seja, considerando como inputs: leitos públicos e médicos, estes foram os Estados mais eficientes em alcançar maior expectativa de vida e taxa de sobrevivência. O Estado da Paraíba, foi $31 \%$ menos eficiente em 2012.

Ressalta-se que não foram consideradas quaisquer outras variáveis como violência urbana e rural, composição da população que podem afetar as variáveis de resultado.

Considerando as variáveis dos inputs e dos outputs em educação, os Estados com melhores desempenhos em 2012 foram: Amapá no IDEB do $5^{\circ}$ ano, e Distrito Federal no IDEB do $9^{\circ}$ ano e do Ensino Médio.

Dessa forma, considerando como input professor por aluno da rede pública estadual, estes foram os Estados mais eficientes alcançar as melhores notas no IDEB. O Estado do Amapá foi $56 \%$ menos eficiente no IDEB do $5^{\circ}$ ano, $38 \%$ menos eficiente no IDEB do $9^{\circ}$ ano, $37 \%$ menos eficiente no IDEB do ensino médio que esses Estados no ano de 2012.

Ressalta-se que não foram consideradas quaisquer outras variáveis como salários dos professores e estrutura escolar (equipamentos, salas, energia e água) que podem afetar o desempenho ao aluno. 
Quadro 31 - Benchmarkings de saúde resultantes da análise envoltória de dados aplicados na hipótese 5 - modelo CCR

\begin{tabular}{|c|c|c|c|c|c|c|c|c|c|c|c|c|c|c|c|c|c|c|}
\hline Estado & 1995 & 1996 & 1997 & 1998 & 1999 & 2000 & 2001 & 2002 & 2003 & 2004 & 2005 & 2006 & 2007 & 2008 & 2009 & 2010 & 2011 & 2012 \\
\hline Acre & 0.84 & 0.97 & 1.00 & 0.63 & 0.87 & 0.53 & 0.52 & 0.54 & 0.53 & 0.77 & 0.91 & 0.93 & 0.91 & 0.85 & 0.84 & 0.77 & 0.85 & 0.83 \\
\hline Alagoas & 0.54 & 0.52 & 0.55 & 0.53 & 0.59 & 0.65 & 0.67 & 0.66 & 0.65 & 0.73 & 0.72 & 0.72 & 0.74 & 0.81 & 0.82 & 0.78 & 0.81 & 1.00 \\
\hline Amapá & 1.00 & 1.00 & 0.81 & 0.93 & 0.75 & 0.75 & 0.77 & 0.82 & 0.88 & 0.92 & 1.00 & 1.00 & 1.00 & 1.00 & 1.00 & 1.00 & 1.00 & 1.00 \\
\hline Amazonas & 0.80 & 0.81 & 0.74 & 1.00 & 0.71 & 0.71 & 0.70 & 0.66 & 0.70 & 0.79 & 0.92 & 0.93 & 0.94 & 0.95 & 0.95 & 0.91 & 0.92 & 0.95 \\
\hline Bahia & 0.72 & 0.69 & 0.81 & 0.79 & 0.85 & 0.71 & 0.70 & 0.70 & 0.67 & 0.81 & 0.80 & 0.82 & 0.79 & 0.85 & 0.86 & 0.76 & 0.78 & 0.81 \\
\hline Ceará & 0.72 & 0.73 & 0.79 & 0.80 & 0.84 & 0.86 & 0.87 & 0.87 & 0.88 & 0.89 & 0.86 & 0.86 & 0.84 & 0.90 & 0.90 & 0.79 & 0.83 & 0.82 \\
\hline Distrito Federal & 0.33 & 0.35 & 0.32 & 0.31 & 0.33 & 0.47 & 0.39 & 0.39 & 0.35 & 0.48 & 0.76 & 0.76 & 0.78 & 0.82 & 0.83 & 0.75 & 0.78 & 0.84 \\
\hline Espírito Santo & 0.51 & 0.52 & 0.53 & 0.62 & 0.56 & 0.65 & 0.64 & 0.65 & 0.61 & 0.74 & 0.86 & 0.86 & 0.89 & 0.93 & 0.94 & 0.90 & 0.92 & 0.94 \\
\hline Goiás & 0.57 & 0.58 & 0.61 & 0.60 & 0.66 & 0.55 & 0.56 & 0.57 & 0.57 & 0.63 & 0.60 & 0.61 & 0.63 & 0.66 & 0.67 & 0.66 & 0.67 & 0.72 \\
\hline Maranhão & 1.00 & 1.00 & 1.00 & 1.00 & 1.00 & 0.82 & 0.83 & 0.84 & 0.87 & 1.00 & 1.00 & 1.00 & 1.00 & 1.00 & 1.00 & 1.00 & 1.00 & 0.90 \\
\hline Mato Grosso & 0.92 & 0.93 & 1.00 & 1.00 & 0.98 & 0.88 & 0.88 & 0.79 & 0.79 & 0.82 & 0.77 & 0.78 & 0.79 & 0.85 & 0.84 & 0.84 & 0.86 & 0.89 \\
\hline Mato Grosso do Sul & 0.82 & 0.83 & 0.78 & 0.74 & 0.78 & 0.90 & 0.89 & 0.85 & 0.85 & 0.85 & 0.65 & 0.66 & 0.74 & 0.86 & 0.87 & 0.88 & 0.92 & 0.94 \\
\hline Minas Gerais & 0.63 & 0.65 & 0.63 & 0.69 & 0.68 & 0.88 & 0.79 & 0.80 & 0.76 & 0.86 & 0.78 & 0.78 & 0.83 & 0.91 & 0.91 & 0.86 & 0.87 & 0.89 \\
\hline Pará & 1.00 & 1.00 & 0.95 & 0.95 & 1.00 & 1.00 & 1.00 & 1.00 & 1.00 & 1.00 & 0.99 & 0.99 & 0.97 & 1.00 & 1.00 & 0.95 & 1.00 & 1.00 \\
\hline Paraíba & 0.55 & 0.54 & 0.55 & 0.56 & 0.60 & 0.55 & 0.55 & 0.55 & 0.56 & 0.64 & 0.64 & 0.65 & 0.64 & 0.68 & 0.69 & 0.64 & 0.69 & 0.69 \\
\hline Par: & 0.68 & 0.72 & 0.72 & 0.74 & 0.78 & 0.93 & 0.86 & 0.88 & 0.81 & 0.85 & 0.65 & 0.66 & 0.69 & 0.75 & 0.74 & 0.70 & 0.70 & 0.74 \\
\hline Pernambu & 0.48 & 0.47 & 0.46 & 0.46 & 0.51 & 0.47 & 0.47 & 0.47 & 0.48 & 0.58 & 0.61 & 0.62 & 0.61 & 0.68 & 0.70 & 0.67 & 0.69 & 0.73 \\
\hline Piauí & 1.00 & 1.00 & 0.79 & 0.81 & 0.78 & 0.72 & 0.71 & 0.70 & 0.75 & 0.85 & 0.83 & 0.83 & 0.81 & 0.82 & 0.81 & 0.72 & 0.76 & 0.70 \\
\hline Rio de Janeiro & 0.24 & 0.25 & 0.29 & 0.31 & 0.26 & 0.31 & 0.32 & 0.35 & 0.34 & 0.45 & 0.62 & 0.61 & 0.63 & 0.68 & 0.69 & 0.68 & 0.72 & 0.77 \\
\hline Rio Grande do Norte & 0.54 & 0.52 & 0.53 & 0.55 & 0.61 & 0.56 & 0.56 & 0.57 & 0.59 & 0.66 & 0.68 & 0.69 & 0.68 & 0.73 & 0.74 & 0.66 & 0.69 & 0.72 \\
\hline Rio Grande do Sul & 0.56 & 0.64 & 0.56 & 0.55 & 0.66 & 1.00 & 1.00 & 1.00 & 1.00 & 1.00 & 0.74 & 0.74 & 0.76 & 0.78 & 0.76 & 0.72 & 0.72 & 0.74 \\
\hline Rondônia & 0.91 & 0.82 & 0.87 & 0.81 & 0.89 & 1.00 & 1.00 & 1.00 & 1.00 & 0.88 & 0.96 & 0.98 & 0.95 & 0.90 & 0.85 & 0.78 & 0.78 & 0.74 \\
\hline Roraima & 1.00 & 0.95 & 0.47 & 0.42 & 0.47 & 0.53 & 0.50 & 0.59 & 0.57 & 0.54 & 0.91 & 0.90 & 0.88 & 0.82 & 0.78 & 0.78 & 0.76 & 0.82 \\
\hline Santa Catarina & 1.00 & 1.00 & 1.00 & 1.00 & 1.00 & 1.00 & 1.00 & 1.00 & 1.00 & 1.00 & 0.72 & 0.74 & 0.78 & 0.83 & 0.82 & 0.79 & 0.80 & 0.83 \\
\hline São Paulo & 0.45 & 0.46 & 0.44 & 0.43 & 0.46 & 0.60 & 0.50 & 0.51 & 0.48 & 0.67 & 0.91 & 0.92 & 0.96 & 1.00 & 0.99 & 0.95 & 0.98 & 1.00 \\
\hline rgipe & 0.86 & 0.81 & 0.77 & 0.90 & 0.81 & 0.93 & 0.95 & 0.90 & 0.88 & 0.89 & 0.75 & 0.75 & 0.77 & 0.88 & 0.93 & 0.95 & 0.92 & 0.94 \\
\hline Tocantins & 0.55 & 0.57 & 0.77 & 0.76 & 0.88 & 0.69 & 0.65 & 0.73 & 0.76 & 0.89 & 0.85 & 0.79 & 0.81 & 0.84 & 0.85 & 0.87 & 0.88 & 0.94 \\
\hline
\end{tabular}

Legenda: inputs - médicos por habitantes do estado e leitos do SUS por habitantes do estado; outputs - expectativa de vida e taxa de sobrevivência. 
Quadro 32 - Benchmarkings de educação resultantes da análise envoltória de dados aplicados na hipótese 5 - modelo CCR

\begin{tabular}{|c|c|c|c|c|c|c|c|c|c|c|c|c|c|c|c|c|c|c|c|c|c|c|c|c|}
\hline \multirow[t]{2}{*}{ Estado } & \multicolumn{8}{|c|}{ Benchmarking Ensino Fundamental Estadual $-5^{\circ}$ ano ${ }^{a}$} & \multicolumn{8}{|c|}{ Benchmarking Ensino Fundamental Estadual $-9^{\circ}$ ano ${ }^{b}$} & \multicolumn{8}{|c|}{ Benchmarking Ensino Médio $-5^{\circ}$ ano ${ }^{\mathrm{c}}$} \\
\hline & 2005 & 2006 & 2007 & 2008 & 2009 & 2010 & 2011 & 2012 & 2005 & 2006 & 2007 & 2008 & 2009 & 2010 & 2011 & 2012 & 2005 & 2006 & 2007 & 2008 & 2009 & 2010 & 2011 & 2012 \\
\hline Acre & 0.65 & 0.72 & 0.93 & 0.96 & 0.97 & 0.95 & 1.00 & 1.00 & 0.86 & 0.78 & 0.56 & 0.55 & 0.69 & 0.68 & 0.70 & 0.76 & 0.76 & 0.91 & 0.82 & 0.79 & 0.82 & 0.79 & 0.86 & 0.82 \\
\hline Alagoas & 0.67 & 0.69 & 0.63 & 0.56 & 0.54 & 0.52 & 0.52 & 0.49 & 0.82 & 0.73 & 0.73 & 0.60 & 0.78 & 0.70 & 0.55 & 0.68 & 1.00 & 0.97 & 0.88 & 0.82 & 0.95 & 0.86 & 0.89 & 0.97 \\
\hline Amapá & 0.49 & 0.44 & 0.41 & 0.44 & 0.46 & 0.44 & 0.48 & 0.44 & 0.93 & 0.75 & 0.62 & 0.55 & 0.63 & 0.58 & 0.59 & 0.62 & 0.76 & 0.77 & 0.66 & 0.61 & 0.61 & 0.67 & 0.68 & 0.63 \\
\hline Amazonas & 0.85 & 0.95 & 1.00 & 1.00 & 1.00 & 1.00 & 0.93 & 0.93 & 0.90 & 0.96 & 0.79 & 0.83 & 1.00 & 1.00 & 0.89 & 1.00 & 0.71 & 0.91 & 0.72 & 0.81 & 0.82 & 0.92 & 0.97 & 0.92 \\
\hline Bahia & 0.68 & 0.66 & 0.60 & 0.58 & 0.52 & 0.64 & 0.68 & 0.55 & 0.67 & 0.62 & 0.56 & 0.49 & 0.60 & 0.60 & 0.52 & 0.56 & 0.80 & 0.90 & 0.76 & 0.71 & 0.72 & 0.72 & 0.75 & 0.64 \\
\hline Ceará & 0.71 & 0.76 & 0.75 & 0.70 & 0.69 & 0.66 & 0.68 & 0.69 & 0.99 & 1.00 & 1.00 & 1.00 & 0.94 & 0.82 & 0.66 & 0.68 & 0.94 & 1.00 & 1.00 & 1.00 & 1.00 & 1.00 & 1.00 & 0.91 \\
\hline Distrito Federal & 1.00 & 1.00 & 0.90 & 0.84 & 0.82 & 0.73 & 0.81 & 0.73 & 1.00 & 0.95 & 0.86 & 0.83 & 0.97 & 0.94 & 1.00 & 1.00 & 0.74 & 0.86 & 0.84 & 0.79 & 0.88 & 0.89 & 0.94 & 1.00 \\
\hline Espírito Santo & 0.72 & 0.74 & 0.71 & 0.69 & 0.64 & 0.54 & 0.52 & 0.44 & 0.82 & 0.76 & 0.70 & 0.68 & 0.79 & 0.64 & 0.55 & 0.56 & 0.73 & 0.80 & 0.67 & 0.68 & 0.70 & 0.67 & 0.70 & 0.65 \\
\hline Goiás & 0.76 & 0.78 & 0.71 & 0.69 & 0.66 & 0.64 & 0.67 & 0.71 & 0.83 & 0.74 & 0.67 & 0.58 & 0.67 & 0.69 & 0.65 & 0.84 & 0.67 & 0.71 & 0.60 & 0.58 & 0.57 & 0.72 & 0.73 & 0.82 \\
\hline Maranhão & 0.71 & 0.69 & 0.68 & $\begin{array}{ll}0.67 \\
\end{array}$ & 0.68 & 0.59 & 0.62 & 0.70 & 0.81 & 0.71 & 0.64 & 0.60 & 0.68 & 0.61 & 0.53 & 0.65 & 0.63 & 0.72 & 0.70 & 0.65 & 0.61 & 0.63 & 0.65 & 0.64 \\
\hline Mato Grosso & 0.65 & 0.76 & 0.74 & 0.66 & 0.67 & 0.71 & 0.65 & 0.56 & 0.66 & 0.72 & 0.60 & 0.63 & 0.75 & 0.75 & 0.66 & 0.66 & 0.59 & 0.74 & 0.54 & 0.48 & 0.49 & 0.60 & 0.60 & 0.53 \\
\hline Mato Grosso do Sul & 0.49 & 0.57 & 0.59 & 0.53 & 0.53 & 0.57 & 0.53 & 0.51 & 0.59 & 0.60 & 0.63 & 0.58 & 0.69 & 0.66 & 0.53 & 0.60 & 0.46 & 0.58 & 0.52 & 0.50 & 0.50 & 0.58 & 0.59 & 0.60 \\
\hline Minas Gerais & 0.81 & 0.70 & 0.74 & 0.73 & 0.72 & 0.69 & 0.70 & 0.67 & 0.82 & 0.72 & 0.64 & 0.63 & 0.74 & 0.75 & 0.69 & 0.79 & 0.74 & 0.77 & 0.64 & 0.59 & 0.59 & 0.66 & 0.69 & 0.68 \\
\hline Pará & 0.79 & 0.77 & 0.80 & 0.78 & 0.83 & 0.80 & 0.76 & 0.59 & 0.89 & 0.71 & 0.85 & 0.68 & 0.89 & 0.83 & 0.70 & 0.69 & 0.82 & 0.81 & 0.95 & 0.91 & 0.96 & 0.96 & 0.93 & 0.85 \\
\hline Paraíba & 0.58 & 0.61 & 0.67 & 0.57 & 0.52 & 0.51 & 0.49 & 0.45 & 0.64 & 0.58 & 0.49 & 0.44 & 0.48 & 0.46 & 0.39 & 0.43 & 0.68 & 0.77 & 0.64 & 0.59 & 0.53 & 0.53 & 0.52 & 0.53 \\
\hline Paraná & 0.73 & 0.62 & 0.72 & $\begin{array}{l}0.57 \\
\end{array}$ & 0.53 & 0.45 & 0.39 & 0.37 & 0.73 & $\begin{array}{l}0.74 \\
\end{array}$ & 0.79 & 0.74 & 0.83 & 0.75 & 0.75 & 0.74 & 0.56 & 0.63 & 0.60 & 0.60 & $\begin{array}{l}0.58 \\
\end{array}$ & 0.59 & 0.60 & 0.54 \\
\hline Pernambuco & 0.64 & 0.66 & 0.63 & 0.59 & 0.57 & 0.57 & 0.60 & 0.55 & 0.73 & 0.68 & 0.56 & 0.58 & 0.68 & 0.67 & 0.63 & 0.72 & 0.78 & 0.87 & 0.71 & 0.64 & 0.63 & 0.70 & 0.75 & 0.85 \\
\hline Piauí & 0.40 & 0.44 & 0.43 & 0.38 & 0.36 & 0.35 & 0.36 & 0.38 & 0.44 & 0.43 & 0.40 & 0.37 & 0.44 & 0.45 & 0.37 & 0.40 & 0.53 & 0.59 & 0.58 & 0.53 & 0.48 & 0.51 & 0.51 & 0.53 \\
\hline Rio de Janeiro & 0.66 & 0.65 & 0.70 & $\begin{array}{l}0.59 \\
\end{array}$ & 0.66 & 0.64 & 0.72 & 0.76 & 0.53 & 0.45 & 0.59 & 0.53 & 0.66 & $\begin{array}{l}0.62 \\
\end{array}$ & 0.47 & 0.54 & 0.46 & 0.50 & 0.59 & 0.51 & 0.51 & $\begin{array}{l}0.61 \\
\end{array}$ & $\begin{array}{l}0.57 \\
\end{array}$ & 0.63 \\
\hline Rio Grande do Norte & 0.51 & 0.56 & 0.54 & 0.52 & 0.52 & 0.52 & 0.55 & 0.52 & 0.72 & 0.64 & 0.59 & 0.53 & 0.65 & 0.62 & 0.50 & 0.59 & 0.89 & 0.91 & 0.83 & 0.75 & 0.75 & 0.84 & 0.86 & 0.83 \\
\hline Rio Grande do Sul & 0.73 & 0.74 & 0.78 & 0.79 & 0.78 & 0.77 & 0.75 & 0.74 & 0.57 & 0.53 & 0.51 & 0.50 & 0.58 & 0.56 & 0.48 & 0.48 & 0.62 & 0.66 & 0.56 & 0.60 & 0.59 & 0.60 & 0.61 & 0.64 \\
\hline Rondônia & 0.72 & 0.73 & 0.67 & 0.58 & 0.55 & 0.55 & 0.59 & 0.63 & 0.89 & 0.81 & 0.71 & 0.67 & 0.80 & 0.76 & 0.68 & 0.74 & 0.67 & 0.70 & 0.61 & 0.70 & 0.70 & 0.64 & 0.65 & 0.65 \\
\hline Roraima & 0.43 & 0.40 & 0.44 & 0.45 & 0.47 & 0.53 & 0.54 & 0.52 & 0.69 & 0.70 & 0.47 & 0.48 & 0.59 & 0.55 & 0.60 & 0.53 & 0.54 & 0.55 & 0.44 & 0.49 & 0.52 & 0.55 & 0.62 & 0.52 \\
\hline Santa Catarina & 0.93 & 0.91 & 0.68 & 0.58 & 0.57 & 0.60 & 0.65 & 0.56 & 0.97 & 0.85 & 0.75 & 0.74 & 0.86 & 0.93 & 0.72 & 0.62 & 0.76 & 0.88 & 0.66 & 0.64 & 0.65 & 0.77 & 0.79 & 0.68 \\
\hline $\begin{array}{l}\text { São Paulo } \\
\end{array}$ & 0.92 & 0.93 & 0.88 & 0.82 & 0.76 & 0.71 & 0.71 & 0.64 & 0.86 & 0.75 & 0.81 & 0.83 & 0.97 & 0.93 & 0.83 & 0.82 & 0.66 & 0.67 & 0.64 & 0.66 & 0.68 & 0.81 & 0.83 & 0.76 \\
\hline Sergipe & 0.63 & 0.62 & 0.63 & 0.55 & 0.51 & 0.49 & 0.52 & 0.49 & 0.72 & 0.59 & 0.55 & 0.44 & 0.53 & 0.61 & 0.48 & 0.43 & 0.77 & 0.72 & 0.64 & 0.62 & 0.60 & 0.70 & 0.67 & 0.62 \\
\hline Tocantins & 0.71 & 0.73 & 0.73 & 0.64 & 0.60 & 0.60 & 0.65 & 0.62 & 0.80 & 0.73 & 0.54 & 0.59 & 0.70 & 0.68 & 0.65 & 0.66 & 0.67 & 0.74 & 0.55 & 0.60 & 0.58 & 0.66 & 0.74 & 0.67 \\
\hline
\end{tabular}

Legenda: inputs - professor por aluno na rede pública estadual urbana e rural; outputs - resultados obtidos no IDEB na rede estadual. a - inputs e outputs do ensino fundamental anos iniciais; b - inputs e outputs do ensino fundamenta anos finais; $\mathbf{c}$ - inputs e outputs do ensino médio. 
Tabela 41 - Resultados da regressão dados painel com efeitos aleatórios: eficiência da função alocativa - ênfase nos resultados alcançados em saúde e educação 2005-2012

\begin{tabular}{|c|c|c|c|c|}
\hline Variáveis & Gini & Theil-T & P10-40 & P20-20 \\
\hline Constante & $0.481890 * * *$ & $0.522373 * * *$ & $9.86306^{* * *}$ & $11.8330 * * *$ \\
\hline Benchmarking Saúde & -0.0273574 & -0.110354 & -1.55113 & -1.45272 \\
\hline Benchmarking EF $5^{\circ}$ ano & $0.100862 * * *$ & $0.238854 * *$ & $9.73923 * * *$ & $11.8330 * * *$ \\
\hline Benchmarking EF $9^{\circ}$ ano & 0.0303063 & 0.0512864 & 2.30055 & -0.517025 \\
\hline Benchmarking EM & -0.0336770 & -0.0997476 & -2.34106 & -2.00115 \\
\hline RNE & $0.0378714 * * *$ & $0.132842 * * *$ & $3.40495 * *$ & $3.51751 * *$ \\
\hline $\mathrm{RCO}$ & 0.000709782 & 0.00460668 & 0.849866 & 0.660824 \\
\hline RSE & -0.0163926 & -0.0323687 & -1.69898 & -2.18105 \\
\hline RSU & $-0.0515445 * * *$ & $-0.118856 * * *$ & $-3.82484 * *$ & $-4.13145^{*}$ \\
\hline Royalties Petróleo/PIB & 1.60628 & 2.06727 & 177.775 & 44.2542 \\
\hline Royalties Setor Elétrico/PIB & 13.8100 & 27.7225 & 807.907 & 153.903 \\
\hline Pooled Simples & Não & Não & Não & Não \\
\hline Efeitos Fixos & Não & Não & Não & Não \\
\hline Efeitos Aleatórios & Sim & Sim & Sim & Sim \\
\hline Teste de Breusch-Pagan (p-valor) & $9.19276 \mathrm{e}-024$ & 0.0405517 & $2.76808 \mathrm{e}-033$ & $3.11104 \mathrm{e}-042$ \\
\hline Teste de Hausman (p-valor) & 0.124857 & 0.319007 & 0.278284 & 0.616611 \\
\hline Normalidade dos Resíduos (p-valor) & 0.04244 & 0.00000 & 0.00000 & 0.00000 \\
\hline Número de Estados & 27 & 27 & 27 & 27 \\
\hline Número de Observações & 216 & 216 & 216 & 216 \\
\hline
\end{tabular}

Fonte: Elaborado pelo autor

Nota: $* * *$ Significativo a $1 \% ; * *$ Significativo a $5 \% ; *$ Significativo a $10 \%$

Tabela 42 - Resultados regressão tobit em painel: eficiência da função alocativa - ênfase nos resultados alcançados em saúde e educação 2005-2012

\begin{tabular}{ccccc}
\hline Variáveis & Gini & Theil-T & P10-40 & P20-20 \\
\hline Constante & $0.539902 * * *$ & $0.551857 * * *$ & $15.2273 * * *$ & $13.9433 * * *$ \\
\hline Benchmarking Saúde & $-0.0614383 * * *$ & -0.107985 & $-5.42657 * *$ & -3.97964 \\
\hline Benchmarking EF 5 ${ }^{\mathbf{a}}$ ano & $0.0762447 * * *$ & $0.235985 * * *$ & $6.97348 * * *$ & $9.38149 * * *$ \\
\hline Benchmarking EF 9 ${ }^{\mathbf{0}}$ ano & 0.000113078 & 0.00251920 & -0.0488612 & -0.862206 \\
\hline Benchmarking EM & -0.0109892 & -0.0874299 & 0.845384 & 1.80133 \\
\hline RNE & $0.026430 * * *$ & $0.127363 * * *$ & $2.31769 * * *$ & $2.76454 * * *$ \\
\hline RCO & 0.000895346 & 0.00781812 & 0.855073 & 0.910958 \\
\hline RSE & $-0.0181797 * * *$ & -0.0319416 & $-1.70234 * *$ & $-2.11935 * * *$ \\
\hline RSU & $-0.0524636 * * *$ & $-0.116577 * * *$ & $-3.89367 * * *$ & $-3.81313 * * *$ \\
\hline Royalties Petróleo/PIB & 1.16941 & 1.16186 & 57.9985 & -38.9769 \\
\hline Royalties Setor Elétrico/PIB & -3.97720 & 16.5459 & $-1156.56 *$ & $-2009.27 * * *$ \\
\hline Normalidade dos Resíduos (p-valor) & 0.00593358 & $9.61616 \mathrm{e}-011$ & $2.20612 \mathrm{e}-012$ & $2.68052 \mathrm{e}-013$ \\
\hline Número de Estados & 27 & 27 & 27 & 27 \\
\hline Número de Observações & 216 & 216 & 216 \\
\hline
\end{tabular}

Fonte: Elaborado pelo autor

Nota: ***Significativo a $1 \%$; **Significativo a $5 \%$; *Significativo a $10 \%$.

Considerando o modelo tobit, observa-se que os Estados mais eficientes em saúde reduziram a desigualdade de renda, enquanto que os Estados mais eficientes em educação no IDEB do $5^{\circ}$ ano agravaram o quadro de desigualdade de renda. Este último resultado foi tão controverso quanto os resultados obtidos nas hipóteses 1 e 4 .

Ainda no modelo tobit, os estados com maior proporção de royalties do setor elétrico reduziram a desigualdade de renda (ressalvada a falta de significância estatística para as variáveis dependentes Gini e Theil-T). 
Com o intuito de explorar a base dados construída, e considerando que o IDEB somente pode ser utilizado desde 2005. Foram repetidos os testes apenas para o benchmarking de saúde considerando o período de 1995 a 2012. O resultado consta nas Tabelas 43 e 44 .

Tabela 43 - Resultados da regressão dados painel com efeitos aleatórios: eficiência da função alocativa resultados alcançados em saúde

\begin{tabular}{ccccc}
\hline Variáveis & Gini & Theil-T & P10-40 & P20-20 \\
\hline Constante & $0.611016^{* * *}$ & $0.770437^{* * *}$ & $24.9671^{* * *}$ & $28.3769^{* * *}$ \\
\hline Benchmarking Saúde & $-0.0780199^{* * *}$ & $-0.193372^{* * *}$ & $-9.14037^{* * *}$ & $-10.7601^{* * *}$ \\
\hline RNE & $0.0263409^{* * *}$ & $0.104863^{* * *}$ & $2.41219^{*}$ & 1.71204 \\
\hline RCO & 0.00326377 & 0.00802528 & 0.488509 & -0.00963482 \\
\hline RSE & -0.0148814 & -0.0423015 & -2.04187 & -2.89129 \\
\hline RSU & $-0.0331320^{* *}$ & $-0.0818349^{* *}$ & $-3.14439^{*}$ & $-3.65314^{*}$ \\
\hline Pooled Simples & Não & Não & Não & Não \\
\hline Efeitos Fixos & Não & Não & Não & Não \\
\hline $\begin{array}{c}\text { Efeitos Aleatórios } \\
\text { Teste de Breusch-Pagan } \\
\text { (p-valor) }\end{array}$ & Sim & Sim & Sim & Sim \\
\hline $\begin{array}{c}\text { Teste de Hausman } \\
\text { (p-valor) }\end{array}$ & $0.14684 \mathrm{e}-041$ & $1.93162 \mathrm{e}-023$ & $8.15844 \mathrm{e}-072$ & $9.30278 \mathrm{e}-092$ \\
\hline $\begin{array}{c}\text { Normalidade dos Resíduos } \\
\text { (p-valor) }\end{array}$ & 0.02298 & 0.426798 & 0.992254 & 0.937828 \\
\hline $\begin{array}{c}\text { Número de Estados } \\
\text { Número de Observações }\end{array}$ & 27 & 0.00000 & 0.00086 & 0.00000 \\
\hline
\end{tabular}

Fonte: Elaborado pelo autor

Nota: $* * *$ Significativo a $1 \%$; **Significativo a $5 \%$; $*$ Significativo a $10 \%$.

Tabela 44 - Resultados da regressão tobit em painel: eficiência da função alocativa - resultados alcançados em saúde

\begin{tabular}{ccccc}
\hline Variáveis & Gini & Theil-T & P10-40 & P20-20 \\
\hline Constante & $0.610164 * * *$ & $0.749474 * * *$ & $24.9532^{* * *}$ & $28.2303 * * *$ \\
\hline Benchmarking Saúde & $-0.0770120^{* * *}$ & $-0.168576^{* * *}$ & $-9.12396^{* * *}$ & $-10.5867 * * *$ \\
\hline RNE & $0.0264394^{* * *}$ & $0.107286^{* * *}$ & $2.41379 * * *$ & $1.72898^{* * *}$ \\
\hline RCO & 0.00339401 & 0.0112291 & 0.490629 & 0.0127589 \\
\hline RSE & $-0.0147108^{* * *}$ & $-0.0381046^{* * *}$ & $-2.03909^{* * *}$ & $-2.86195^{* * *}$ \\
\hline RSU & $-0.0330988^{* * *}$ & $-0.0810182^{* * *}$ & $-3.14385^{* * *}$ & $-3.64743^{* * *}$ \\
\hline $\begin{array}{c}\text { Normalidade dos Resíduos } \\
\text { (p-valor) }\end{array}$ & 0.00335944 & 0.134323 & $9.47567 \mathrm{e}-005$ & $1.14721 \mathrm{e}-015$ \\
\hline Número de Estados & 27 & 27 & 27 & 27 \\
\hline Número de Observações & 486 & 486 & 486 & 486 \\
\hline
\end{tabular}

Fonte: Elaborado pelo autor

Nota: ***Significativo a $1 \%$;* Significativo a $5 \%$; *Significativo a $10 \%$.

Ao retirar da análise os benchmarkings de saúde, retirar os royalties e aumentar a amplitude da análise dos dados, observa-se que em todos os cenários os Estados mais eficientes em saúde reduziram a desigualdade de renda.

Além disso, o efeito regional corroborou achados anteriores: que as regiões Sul e Sudeste obtiveram desempenho superior a região Norte em relação a redução da desigualdade renda, enquanto que a região Norte obteve desempenho superior a região Nordeste. 


\subsection{Resultados da hipótese 6}

Da mesma forma que nas hipóteses 4 e 5, a hipótese 5 também utilizou uma abordagem semiparamétrica em dois estágios. No $1^{\circ}$ estágio foram calculados para cada ano, de 1995 a 2012, os benchmarkings de referência de arrecadação em IPTU e ITR; e de 1998 a 2012, os benchmarkings de referência de arrecadação em IPVA.

No $2^{\circ}$ estágio, esses benchmarkings foram introduzidos no modelo. Os Quadros 31 e 32 contêm o desempenho dos Estados na arrecadação do IPTU e ITR; e do IPVA respectivamente.

Considerando as variáveis dos inputs e dos outputs na arrecadação do IPTU e ITR, o Estado com melhor desempenho em todos os anos foi o Distrito Federal. Ou seja, considerando como inputs: área líquida disponível para arrecadar, este foi o Estado mais eficiente na arrecadação destes dois impostos progressivos. O Estado do Acre foi $99 \%$ menos eficiente no ano de 2012 nesse quesito.

Considerando as variáveis dos inputs e dos outputs na arrecadação do IPVA, o Estado com melhor desempenho modo geral em todos os anos foi o Estado de São Paulo. Ou seja, considerando como inputs: quantidade de veículos automotores, este foi o Estado mais eficiente na arrecadação deste imposto progressivo. O Distrito Federal foi $21 \%$ menos eficiente no ano de 2012 nesse quesito.

Observa-se nas Tabelas 45 e 46 que os Estados mais eficientes na arrecadação do IPVA (benchmarking frota) reduziram a desigualdade de renda, enquanto que os Estados mais na arrecadação do IPTU e ITR agravaram o quadro de desigualdade de renda. Este último resultado está alinhado aos resultados obtidos na hipótese 2.

Dessa forma, considerando todas as limitações do trabalho, o modelo de arrecadação do IPTU e ITR não está propiciando o enfrentamento da desigualdade de renda, enquanto o modelo do IPVA está cumprindo tal finalidade. 
Quadro 33 - Benchmarkings da arrecadação sobre a área territorial dos estados resultantes da análise envoltória de dados aplicados na hipótese 6 - modelo CCR

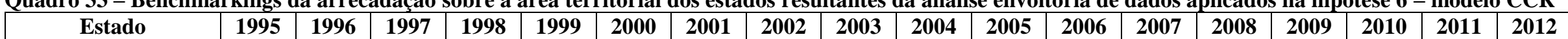

\begin{tabular}{|c|c|c|c|c|c|c|c|c|c|c|c|c|c|c|c|c|c|c|}
\hline & & & & & & & & & & & & & & & & & & \\
\hline Acre & 002 & 0.001 & 001 & 0.001 & 001 & 0.001 & 001 & 0.001 & 000 & 0.000 & .000 & 0.000 & 0.001 & 0.001 & 0.001 & 0.000 & 0.001 & $\overline{001}$ \\
\hline Alago & & 003 & & & & & & & & & & & & & & & & \\
\hline Amapá & 001 & 000 & 001 & 000 & 000 & .000 & 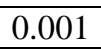 & .000 & 000 & 0.000 & 002 & .000 & .000 & .000 & .000 & .000 & 00 & .000 \\
\hline Amazonas & 001 & .001 & 001 & .001 & 0.000 & 0.001 & .001 & 0.000 & .000 & 0.000 & .001 & 0.001 & .001 & 0.001 & 0.001 & .001 & 001 & .001 \\
\hline & 14 & 013 & .012 & 016 & 0.011 & .012 & 10 & 0.008 & 99 & 0.008 & 08 & 0.008 & 99 & 0.007 & & 08 & & 09 \\
\hline C & & 017 & & 017 & & 01 & & 80 & & & & & & & & & & \\
\hline Distrito Federal & 000 & 1.000 & 1.000 & 1.000 & 1.000 & 1.000 & 1.000 & 1.000 & 1.000 & 1.000 & 1.000 & 1.000 & 1.000 & 1.000 & 1.000 & 1.000 & & .000 \\
\hline Espí & 056 & 0.047 & 0.040 & 0.042 & 0.037 & 0.046 & 0.043 & 0.031 & 0.035 & 0.033 & 0.033 & 0.035 & .041 & 0.034 & 0.036 & .038 & .041 & .043 \\
\hline & 024 & 020 & 0.020 & .018 & 0.013 & 0.02 & 0.020 & 0.013 & - & 0.014 & 0.014 & 0.017 & 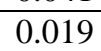 & $C^{\circ}$ & 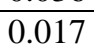 & 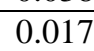 & & 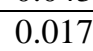 \\
\hline Ma & & 00 & & 0.00 & 0.002 & 0.0 & 04 & 0.0 & 02 & 0.0 & 2 & 0.002 & 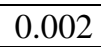 & 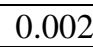 & & 2 & & 02 \\
\hline Mato & & .003 & 0.002 & 0.003 & 0.003 & 0.006 & 04 & 0.00 & .004 & 0.003 & 0.002 & 0.002 & 2 & 0.002 & 0.002 & 002 & & .002 \\
\hline Mato & & .014 & & 0.0 & & 0.0 & & 0.0 & 0.0 & 0.0 & & 0.0 & & 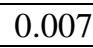 & & U & & 11 \\
\hline & 044 & .040 & 0.040 & .042 & 0.034 & 0.038 & .039 & 0.027 & 28 & 0.027 & 0.026 & 0.027 & 0.027 & 24 & 0.0 & 21 & & .030 \\
\hline & 002 & .002 & 0.002 & 0.001 & 0.001 & 0.001 & 01 & 0.010 & 0.001 & 0.001 & 01 & 0.001 & 0.001 & 001 & 0.001 & 001 & 1 & .001 \\
\hline & & 012 & & 0.003 & 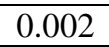 & 0.0 & & & & 2 & & 2 & & & & & & $\overline{12}$ \\
\hline & 93 & .086 & 0.081 & 0.084 & 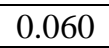 & 0.07 & $\overline{0}$ & 0.0 & .064 & 0.065 & 0 & 0.0 & 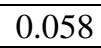 & 1 & & 6 & & .062 \\
\hline Pernambu & 062 & 0.061 & 0.058 & 0.054 & 0.045 & 0.055 & 0.055 & 0.042 & 0.044 & 0.044 & 0.044 & 0.044 & 0.044 & 0.042 & 0.042 & .042 & 0.042 & 0.045 \\
\hline & & 0.002 & 0. & 0.002 & 0.002 & 0.002 & 0.0 & 0.005 & 0.0 & 0.002 & 0.0 & 0.001 & 0. & 0.001 & & 02 & & .002 \\
\hline 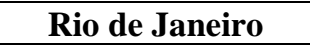 & & 1000 & 4 & 1.000 & 10 & 1.000 & 10 & 07 & 88 & 0827 & 0.790 & 0743 & 0.738 & 0.682 & 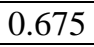 & 3 & 1 & .667 \\
\hline Rio G & 0.023 & .023 & 0.022 & .019 & 0.014 & 0.016 & 020 & 0.065 & 016 & 0.015 & 16 & 0.017 & 0.018 & 0.015 & 0.016 & 017 & 0.018 & .019 \\
\hline Rio Gra & 0.066 & 0.062 & 0.056 & 0.058 & 0.044 & 0.053 & 0.058 & 0.041 & 0.048 & 0.042 & 0.042 & 0.041 & 0.043 & 0.039 & 0.039 & .041 & 0.041 & .042 \\
\hline & & .002 & & 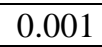 & & & & 0.003 & & 0.001 & & 0.001 & & & & & & \\
\hline & & 000 & 0.0 & 000 & 0.0 & 0 & 000 & 0.000 & .000 & 0.000 & 0.000 & 0.000 & 0 & 0 & 1 & 01 & 1 & 01 \\
\hline Santa Catarin & 0.110 & 0.084 & 0.072 & 0.089 & 0.073 & 0.074 & 0.078 & 0.060 & 0.074 & 0.078 & 0.079 & 0.082 & 0.082 & 0.075 & 0.079 & .086 & 0.083 & .082 \\
\hline São Paulo & 89 & 614 & 0.5 & 0.565 & 0.5 & 0.557 & 0.640 & 0.506 & 0.5 & 0.5 & 0.513 & 0.516 & 0.521 & 0.450 & 51 & 86 & 1 & .508 \\
\hline & & 0.070 & & 0.05 & & 0.0 & & & & & & 0.036 & & & & 0.037 & & 442 \\
\hline Tocantins & 0.003 & 0.002 & 0.002 & 0.002 & 0.001 & 0.003 & 0.003 & 0.008 & 0.002 & 0.002 & 0.001 & 0.001 & 0.001 & 0.001 & 0.001 & 0.001 & 0.001 & 0.002 \\
\hline
\end{tabular}

Legenda: inputs - área territorial do estado após deduções: terras indígenas e áreas de proteção ambiental; outputs - receitas de IPTU e ITR. 
Quadro 34 - Benchmarkings da arrecadação sobre frota de veículos automotores resultantes da análise envoltória de dados aplicados na hipótese 6 - modelo CCR

\begin{tabular}{|c|c|c|c|c|c|c|c|c|c|c|c|c|c|c|c|}
\hline Estado & 1998 & 1999 & 2000 & 2001 & 2002 & 2003 & 2004 & 2005 & 2006 & 2007 & 2008 & 2009 & 2010 & 2011 & 2012 \\
\hline Acre & 0.081 & 0.138 & 0.191 & 0.468 & 0.448 & 0.438 & 0.425 & 0.385 & 0.395 & 0.444 & 0.465 & 0.427 & 0.434 & 0.431 & 0.431 \\
\hline Alagoas & .147 & 0.312 & 0.293 & 0.611 & 0.530 & 0.629 & 0.617 & 0.634 & 0.612 & 0.597 & 0.586 & 0.564 & 0.558 & 0.546 & 0.553 \\
\hline Amapá & 1.000 & 0.408 & 0.281 & 0.755 & 0.740 & 0.772 & 0.749 & 0.729 & 0.714 & 0.717 & 0.705 & 0.672 & 0.630 & 0.647 & 0.634 \\
\hline Amazonas & 0.173 & 0.313 & 0.310 & 0.672 & 0.672 & 0.708 & 0.721 & 0.717 & 0.693 & 0.705 & 0.687 & 0.601 & 0.682 & 0.646 & 0.627 \\
\hline Bahia & 0.268 & 0.459 & 0.410 & 0.474 & 0.445 & 0.602 & 0.608 & 0.604 & 0.566 & 0.553 & 0.563 & 0.524 & 0.520 & 0.511 & 0.510 \\
\hline Ceará & 0.114 & 0.213 & 0.300 & 0.477 & 0.449 & 0.460 & 0.449 & 0.428 & 0.413 & 0.404 & 0.414 & 0.403 & 0.401 & 0.411 & 0.413 \\
\hline Distrito Federal & 0.331 & 0.631 & 0.628 & 0.788 & 0.843 & 0.857 & 0.937 & 0.977 & 0.977 & 0.943 & 0.982 & 1.000 & 0.943 & 0.984 & 0.797 \\
\hline Espírito Santo & 0.303 & 0.372 & 0.359 & 0.401 & 0.411 & 0.444 & 0.526 & 0.533 & 0.521 & 0.545 & 0.547 & 0.544 & 0.543 & 0.531 & 0.525 \\
\hline Goiás & 0.084 & 0.145 & 0.140 & 0.601 & 0.572 & 0.509 & 0.499 & 0.482 & 0.468 & 0.408 & 0.395 & 0.415 & 0.457 & 0.477 & 0.471 \\
\hline Maranhão & 0.135 & 0.316 & 0.331 & 0.569 & 0.522 & 0.565 & 0.587 & 0.589 & 0.562 & 0.539 & 0.534 & 0.493 & 0.478 & 0.466 & 0.463 \\
\hline Mato Grosso & 0.129 & 0.400 & 0.359 & 0.633 & 0.596 & 0.609 & 0.562 & 0.584 & 0.583 & 0.503 & 0.484 & 0.489 & 0.487 & 0.494 & 0.506 \\
\hline Mato Grosso do Sul & 0.114 & 0.217 & 0.214 & 0.430 & 0.433 & 0.461 & 0.523 & 0.494 & 0.492 & 0.483 & 0.461 & 0.455 & 0.450 & 0.435 & 0.454 \\
\hline Minas Gerais & 0.228 & 0.419 & 0.484 & 0.746 & 0.730 & 0.696 & 0.763 & 0.744 & 0.769 & 0.741 & 0.730 & 0.698 & 0.714 & 0.722 & 0.741 \\
\hline Pará & 0.192 & 0.360 & 0.281 & 0.613 & 0.574 & 0.575 & 0.576 & 0.569 & 0.575 & 0.563 & 0.568 & 0.535 & 0.531 & 0.527 & 0.520 \\
\hline Paraíba & 0.076 & 0.143 & 0.129 & 0.454 & 0.417 & 0.427 & 0.429 & 0.443 & 0.403 & 0.384 & 0.376 & 0.369 & 0.362 & 0.365 & 0.378 \\
\hline Paraná & 0.098 & 0.181 & 0.203 & 0.519 & 0.533 & 0.565 & 0.553 & 0.548 & 0.538 & 0.539 & 0.571 & 0.578 & 0.577 & 0.586 & 0.595 \\
\hline Pernambu & 0.162 & 0.307 & 0.298 & 0.537 & 0.484 & 0.590 & 0.591 & 0.580 & 0.559 & 0.532 & 0.525 & 0.510 & 0.503 & 0 & 0.523 \\
\hline Piauí & 0.246 & 0.419 & 0.202 & 0.426 & 0.433 & 0.230 & 0.505 & 0.467 & 0.437 & 0.205 & 0.203 & 0.376 & 0.388 & 0.193 & 0.381 \\
\hline Rio de Jan & 0.213 & 0.393 & 0.478 & 0.908 & 0.900 & 0.907 & 0.901 & 0.857 & 01 & 50 & 0.739 & 0.780 & 0.690 & 72 & 0.683 \\
\hline Rio Grande do Norte & 0.255 & 0.329 & 0.293 & 0.533 & 0.491 & 0.483 & 0.509 & 0.515 & 23 & 0.487 & 0.484 & 0.465 & 458 & 56 & 0.467 \\
\hline Rio Grande do Sul & 0.262 & 0.476 & 0.475 & 0.754 & 0.598 & 0.712 & 0.617 & 0.596 & 0.571 & 0.544 & 0.554 & 0.705 & 663 & 0.667 & 0.682 \\
\hline Rondônia & 0.395 & 0.397 & 0.224 & 0.427 & 0.442 & 0.541 & 0.518 & 0.393 & 0.537 & 0.422 & 0.443 & 0.410 & 429 & 0.397 & 0.400 \\
\hline Roraima & 0.538 & 0.177 & 0.152 & 0.346 & 0.331 & 0.371 & 0.330 & 0.309 & 0.270 & 0.256 & 0.319 & 0.316 & 0.383 & 0.431 & 0.443 \\
\hline Santa Catari & 0.171 & 0.299 & 0.345 & 0.472 & 0.493 & 0.501 & 0.498 & 0.511 & 0.258 & 0.260 & 0.265 & 0.539 & 0.554 & 0.562 & 0.581 \\
\hline São Paulo & 0.821 & 1.000 & 1.000 & 1.000 & 1.000 & 1.000 & 1.000 & 1.000 & 1.000 & 1.000 & 1.000 & 0.994 & 1.000 & 1.000 & 1.000 \\
\hline Sergipe & 0.062 & 0.117 & 0.137 & 0.333 & 0.326 & 0.342 & 0.422 & 0.404 & 0.393 & 0.402 & 0.395 & 0.384 & 0.409 & 0.410 & 0.422 \\
\hline Tocantins & 0.306 & 0.516 & 0.428 & 0.478 & 0.444 & 0.454 & 0.440 & 0.395 & 0.383 & 0.418 & 0.400 & 0.365 & 0.390 & 0.414 & 0.420 \\
\hline
\end{tabular}

Legenda: inputs - veículos; outputs - receita do IPVA 
Tabela 45 - Resultados da regressão dados painel com efeitos aleatórios: eficiência da função distributiva - arrecadação de impostos progressivos 1998-2012

\begin{tabular}{ccccc}
\hline Variáveis & Gini & Theil-T & P10-40 & P20-20 \\
\hline Constante & $0.564868^{* * *}$ & $0.653823^{* * *}$ & $19.4539^{* * *}$ & $21.5232^{* * *}$ \\
\hline Benchmarking Área & $0.0842884^{* * *}$ & $0.156579^{* * *}$ & $10.2013^{* * *}$ & $12.4843^{* * *}$ \\
\hline Benchmarking Frota & $-0.0614126^{* * *}$ & $-0.131881^{* * *}$ & $-6.84766^{* * *}$ & $-7.68092^{* * *}$ \\
\hline RNE & $0.0341046^{* * *}$ & $0.120495^{* * *}$ & $3.49981^{* * *}$ & $3.43620^{* * *}$ \\
\hline RCO & -0.00299060 & 0.000550723 & -0.283429 & -0.939061 \\
\hline RSE & $-0.00667699^{* *}$ & -0.0107017 & -0.927118 & -1.53483 \\
\hline RSU & -0.0261026 & $-0.0779768^{* * *}$ & $-1.97749^{*}$ & -1.78567 \\
\hline $\begin{array}{c}\text { Royalties } \\
\text { Petróleo/PIB }\end{array}$ & -1.51710 & $-6.42691^{*}$ & -184.508 & -249.143 \\
\hline $\begin{array}{c}\text { Royalties Setor } \\
\text { Elétrico/PIB }\end{array}$ & 5.88243 & 13.7322 & 44.6972 & -172.131 \\
\hline Pooled Simples & Não & Não & Não & Não \\
\hline Efeitos Fixos & Não & Não & Não & Não \\
\hline Efeitos Aleatórios & Sim & Sim & Sim & Sim \\
\hline $\begin{array}{c}\text { Teste de Breusch- } \\
\text { Pagan (p-valor) }\end{array}$ & $6.08215 \mathrm{e}-021$ & $4.29303 \mathrm{e}-006$ & $1.37319 \mathrm{e}-035$ & $5.56576 \mathrm{e}-045$ \\
\hline $\begin{array}{c}\text { Teste de Hausman } \\
\text { (p-valor) }\end{array}$ & 0.235416 & 0.346699 & 0.279333 & 0.146189 \\
\hline $\begin{array}{c}\text { Normalidade dos } \\
\text { Resíduos (p-valor) }\end{array}$ & 0.50078 & 0.00000 & 0.00508 & 0.00000 \\
\hline Número de Estados & 27 & 27 & 27 & 27 \\
\hline $\begin{array}{c}\text { Número de } \\
\text { Observações }\end{array}$ & 405 & 405 & 405 & 405 \\
\hline Fon Elabora pelo & & & \\
\hline
\end{tabular}

Fonte: Elaborado pelo autor

Nota: $* * *$ Significativo a $1 \%$; **Significativo a $5 \%$; $*$ Significativo a $10 \%$.

Tabela 46 - Resultados da regressão tobit em painel: eficiência da função distributiva arrecadação de impostos progressivos 1998-2012

\begin{tabular}{ccccc}
\hline Variáveis & Gini & Theil-T & P10-40 & P20-20 \\
\hline Constante & $0.567854^{* * *}$ & $0.655360^{* * *}$ & $19.7724^{* * *}$ & $21.9476^{* * *}$ \\
\hline Benchmarking Área & $0.0801743^{* * *}$ & $0.152099^{* * *}$ & $10.0790^{* * *}$ & $12.0469^{* * *}$ \\
\hline Benchmarking Frota & $-0.0556755^{* * *}$ & $-0.124443^{* * *}$ & $-5.97665^{* * *}$ & $-6.18364^{* * *}$ \\
\hline RNE & $0.0286355^{* * *}$ & $0.118399^{* * *}$ & $2.74408^{* * *}$ & $2.29849^{* * *}$ \\
\hline RCO & -0.00651231 & -0.00686721 & -0.543245 & $-1.24667^{*}$ \\
\hline RSE & $-0.0166253^{* * *}$ & -0.0264267 & $-2.45411^{* * *}$ & $-3.53854^{* * *}$ \\
\hline RSU & $-0.0430531^{* * *}$ & $-0.103858^{* * *}$ & $-3.76631^{* * *}$ & $-4.14688^{* * *}$ \\
\hline Royalties Petróleo/PIB & -1.49905 & $-6.97142^{* * *}$ & $-231.415^{* *}$ & $-326.612^{* * *}$ \\
\hline $\begin{array}{c}\text { Royalties Setor } \\
\text { Elétrico/PIB }\end{array}$ & 6.74472 & $23.8084^{*}$ & 93.7725 & -326.612 \\
\hline $\begin{array}{c}\text { Normalidade dos Resíduos } \\
\text { (p-valor) }\end{array}$ & 0.104847 & 0.0033386 & 0.000520021 & $1.41773 \mathrm{e}-012$ \\
\hline Número de Estados & 27 & 27 & 27 & 27 \\
\hline Número de Observações & 405 & 405 & 405 & 405 \\
\hline Fur
\end{tabular}

Fonte: Elaborado pelo autor

Nota: $* * *$ Significativo a $1 \% ; * *$ Significativo a $5 \% ; *$ Significativo a $10 \%$. 


\section{CONCLUSÃO}

A desigualdade de renda é um fenômeno social que justifica a intervenção estatal na economia. No entanto, é necessário que os tomadores de decisão pública tenham capacidade de identificar quais intervenções realmente podem ou deveriam vir a surtir efeito com esse propósito.

Este estudo teve por objetivo avaliar o impacto das funções orçamentárias alocativa e distributiva sobre a desigualdade de renda. Doutrinariamente a função alocativa oferta bens meritórios em saúde e educação que geram externalidades positivas sobre a sociedade, enquanto a função distributiva por intermédio dos impostos progressivos e transferências de renda direta busca redistribuir a riqueza dentro da sociedade indo de encontro ao ideal de Pareto.

Este estudo utilizando de ajustes metodológicos abarcou o período de 1995 a 2012: um período de relativa estabilidade do plano real. Esse fator foi importante para mitigar efeitos inflacionários agudos sobre as políticas de gastos e receitas aqui estudadas.

Conforme se pode observar, o estudo se dividiu em duas fases, cada uma com três hipóteses a serem testadas. Na primeira fase, foram considerados: (i) os efeitos das despesas com educação e saúde sobre a desigualdade de renda; (ii) os efeitos dos impostos progressivos sobre a desigualdade de renda; (iii) os efeitos das transferências de renda direta sobre a desigualdade de renda. Em ambos os casos, utilizam-se os índices de Gini, Theil-T, proporção entre os $10 \%$ mais ricos e os $40 \%$ mais pobres, proporção entre os $20 \%$ mais ricos e os $20 \%$ mais pobres. A relação funcional entre o índice de Gini e as funções alocativa e distributiva foi explorada a partir de uma regressão tobit e de uma regressão em painel com efeitos aleatórios.

Concluiu-se nessa primeira fase que os Estados com maior proporção de gastos na função saúde em relação ao PIB estadual, com maior proporção de imposto sobre veículos automotores em relação ao PIB estadual, com maior proporção de imposto sobre transmissão de bens causa mortis e doação em relação ao PIB estadual, com maior proporção de imposto sobre transferência de bens intervivos em relação ao PIB estadual, e com maior proporção de benefícios de prestação continuada ao idoso em relação ao PIB estadual reduziram a desigualdade de renda nesse período. 
Porém, foram identificados os seguintes resultados controversos à luz da doutrina das funções orçamentárias alocativa e distributiva, dos quais se destacam: os estados que mais investiram na função educação em relação ao PIB estadual agravaram o quadro de desigualdade de renda; o imposto de renda e o imposto territorial, impostos progressivos, também estariam agravando esse quadro; e o imposto predial territorial urbano não está cumprindo de igual modo sua função social de reduzir as desigualdades de renda.

Durante o estudo, a fim de qualificar ainda mais essa observação sobre os gastos na função educação, foi realizado o estudo por subfunções do gasto (decomposição da função). Nessa fase de avaliação o resultado foi inconclusivo nos gastos com educação.

Diante do exposto nessa primeira fase, faz-se necessário questionar se de fato há uma política de melhoria da situação das famílias desfavorecias em renda, ou se de fato, as políticas de receitas, especialmente os impostos federais e despesas em educação e outros gastos meritórios, não se mostraram organizados de forma empírica para alcançar este objetivo.

Na segunda fase do estudo foram considerados: (i) o efeito da eficiência da alocação de recursos financeiros na geração de produtos e serviços em saúde e educação sobre a desigualdade de renda; (ii) o efeito da eficiência da alocação de produtos e serviços na geração de resultados em saúde e educação sobre a desigualdade de renda; (iii) o efeito da eficiência na arrecadação de impostos progressivos sobre a desigualdade de renda. Nesta fase, foi utilizado um método semiparamétrico em dois estágios. No primeiro estágio, se obteve a partir da análise envoltória de dados, os escores de eficiência (benchmarkings) das unidades da federação em relação a cada hipótese. E no segundo estágio, utilizou-se a regressão tobit e a regressão em painel com efeitos aleatórios.

Analisando os resultados da segunda fase, sem perder de vista os resultados obtidos na primeira fase, conclui-se, com todas as limitações expostas neste trabalho, que os estados mais eficientes em “ofertar" produtos e serviços em saúde a partir de recursos financeiros conseguiram reduzir a desigualdade, ao passo que os estados mais eficientes em "ofertar" produtos e serviços em educação a partir de recursos financeiros conseguiram agravar a desigualdade. Esse resultado na segunda fase, por mais controverso que seja, está alinhado ao resultado na primeira fase. Em outras palavras, se o maior volume de recursos em educação proporcionalmente ao PIB estadual agravava a desigualdade de renda, ser eficiente nessa seara tenderia também a agravar. Tal apontamento empírico leva a uma reflexão se o modelo atualmente existente está ou não estruturado para enfrentar a desigualdade de renda. 
Em outra perspectiva de eficiência, também ligada à função orçamentária alocativa, conclui-se que os estados mais eficientes em alcance de resultados de política de saúde tendo como resultados o aumento da expectativa de vida e a redução da taxa de mortalidade (no corpo do trabalho tratada como aumento da taxa de sobrevivência) conseguiram reduzir a desigualdade de renda. Novamente, de forma controversa perante a doutrina sobre a função orçamentária alocativa, os estados mais eficientes em resultados no índice de desenvolvimento do ensino básico tenderam a agravar o quadro de desigualdade. Esse resultado reforçou os dois resultados anteriores controversos na área de educação.

Por fim, concluiu-se, nessa segunda fase, que os Estados mais eficientes na arrecadação do imposto sobre veículos automotores reduziram a desigualdade de renda e que os Estados mais eficientes na arrecadação do IPTU e do ITR, agravaram o quadro de desigualdade de renda. Sem perder de vista os resultados na primeira fase, observa-se que ser eficiente na arrecadação de imposto progressivo que em termos arrecadação proporcional ao PIB estadual que já contribuía para redução da desigualdade de renda tende a acentuar esse enfrentamento. De igual modo, ser eficiente na arrecadação de um imposto progressivo que não cumpria o seu papel, tende a agravar o cenário.

Dentre as limitações do trabalho estão: (i) as variáveis orçamentárias disponibilizadas no site da Secretaria do Tesouro Nacional no período analisado não contêm os dados de todos os municípios; (ii) a ausência de segregação entre 1995 e 2001 das despesas na função saúde (que estava agregada com saneamento) e na função educação (que estava agregada com cultura) o que motivou a utilização de procedimento metodológico para efetuar a desagregação; (iii) a ausência de segregação entre 1995 e 2003 nas despesas por subfunção o que motivou a utilização de procedimento metodológico para efetuar a desagregação; os dados sobre imposto de renda federal e imposto territorial urbano entre os anos de 1995 e 1999 não foram disponibilizados pela Secretaria da Receita Federal o que motivou a utilização de procedimento metodológico para efetuar o preenchimento dessas lacunas; os dados sobre os impostos estaduais entre 1995 e 2000 não eram segregados o que motivou a utilização de procedimento metodológico para efetuar a desagregação; os dados sobre os impostos municipais entre 1995 e 1996 não eram segregados o que motivou a utilização de procedimento metodológico para efetuar a desagregação. 
Espera-se que trabalhos futuros possam contra argumentar e dar novos caminhos para os resultados controversos aqui evidenciados, em especial: os gastos com educação, e a progressividade do Imposto de Renda, do Imposto Territorial Rural e do Imposto Predial Territorial Urbano. 


\section{REFERÊNCIAS}

AFONSO, A.; AUBYN, M. S. T. Non-parametric aproaches to education and health efficiency in OECD countries. Journal of Aplied Economics, vol. VIII, n.2, 227-246, nov. 2005.

AFONSO, A.; SCHUKNECHT, L; TANZI, V. Public sector efficiency: an international comparison. Public Choice, v. 123, p. 321-347, 2005.

ALI, M.; FJELDSTAD, O.; SJURSEN, I. H. To Pay or Not to Pay? Citizens' Attitudes Toward Taxation in Kenya, Tanzania, Uganda, and South Africa. World Development, v. 64, dec., p. 828-842, 2014.

ARAÚJO, J. M.; ALVES, J. A.; BESARRIA, C. N. O impacto dos gastos sociais sobre os indicadores de desigualdade e pobreza nos estados brasileiros no período de 2004 a 2009. Rev. econ. contemp., Rio de Janeiro , v. 17, n. 2, p. 249-275, Aug. 2013.

ATKINSON, A. B. The economics of inequality. Oxford: Claredon Press, 1975.

BAHL, R.; WALLACE, S. Public Financing in Developing and Transition countries. Public Budgeting \& Finance. Silver Anniversary Issue, volume 25, p 83-98, 2005.

BALTAGI, Badi H. Econometric Analysis of Panel Data, 3 ed. New York: Wiley, 2005.

BANKER, R.; CHARNES, A.; COOPER, William W. Some models for estimating technical and scale inefficiencies in data envelopment analysis. Management Science, v. 30, p. 1078-1092, 1984.

BASSETT, W. F.; BURKETT, J. P.; PUTTERMAN, L. Income distribution, government transfers, and the problem of unequal influence. European Journal of Political Economy, 15, p. 207-28, 1999.

BERGH, A.; FINK, G. Higher education policy, enrollment, and income inequality. Social Science Quarterly, 89 (1), 217-235, 2008.

BRASIL. Constituição da República Federativa do Brasil. Diário Oficial [da] República Federativa do Brasil, Poder Legislativo, Brasília, DF, 5 out. 1988.

Lei $\mathrm{n}^{\circ} 13.242$ de 30 de dezembro de 2015. Dispõe sobre as diretrizes para a elaboração e execução da Lei Orçamentária de 2016 e dá outras providências. Diário Oficial [da] República Federativa do Brasil, Poder Executivo, Brasília, DF, 31 dez. 2015.

BRAVO-URETA, B.E., SOLFS, D., LOPEZ, V.H.M., MARIPANI, J.F., THIAM, A., RIVAS, T. Technical efficiency in farming - a meta-regression analysis. Journal of Productivity Analysis, 27, 37-72, 2007. 
BROOKS, C. Introductory Econometrics for Finance. Cambridge University Press: Cambridge, 2008.

BRUE, S. L. História do pensamento econômico. 6 ed. Editora Thomson, 2005.

BRUNET, J. F. G.; BORGES, C B.; BERTÊ, A. M.A. Estados comparados por funções do orçamento uma avaliação da eficiência e efetividade dos gastos públicos estaduais. Menção Honrosa I, Prêmio Ipea-Caixa, 2006.

CARVALHO, F. J. C. Equilíbrio fiscal e política econômica keynesiana. Análise Econômica, p. 7-26, 2008.

CASTRONOVA, E. Inequality and income: The mediating effects of social spending and risk. Economics of Transition, 9 (2), p. 395-415, 2001.

CAVALCANTI, Daniella Medeiros; COSTA, Edward Martins; SILVA, Jorge Luiz Mariano da. Programa bolsa família e o nordeste: impactos na renda e na educação, nos anos de 2004 e 2006. Rev. econ. contemp., Rio de Janeiro, v. 17, n. 1, p. 99128, Apr. 2013.

CHARNES, A.; COOPER, W.W.; RHODES, E. Measuring the efficiency of decision making units. European Journal of Operational Research, 2, p.429-444, 1978.

CHILINGERIAN, J.A. Evaluating physician efficiency in hospitals: A multivariate analysis of best practices. European Journal of Operational Research, 548-574, 1995.

CHRISTENSEN, R.; WISE, C. R. Dead or alive? The federalism revolution and its meaning for public administration. Public Administration Review, p.920-931, Sep./Oct. 2009.

CHRISTIAENSEN, L.; TODO, Y. Poverty Reduction During the Rural-Urban Transformation - The Role of the Missing Middle. World Development, v. 63, nov. p. 43-58, 2014.

CINGANO, F. Trends in Income Inequality and its Impact on Economic Growth, OECD Social, Employment and Migration Working Papers, $n^{\circ} 163$, OECD Publishing, 2014.

COOPER, W. W.; SEIFORD, L. M.; TONE, K. Introduction to Data Envelopment Analysis and Its Uses. 2 ed. Nova Iorque: Springer, 2007.

CORDATO, Roy E. The Austrian Theory of Efficiency and the Role of Government. The Journal of Libertarian Studies, vol. IV, n. 4, Fall, 1980.

COSTA, A. A. B.; SAVANATO, M. A.; DINIZ, S. C. Análise do Programa de transferência de renda Bolsa Família para o período 2004-2006: impactos sobre pobreza, desigualdade e focalização. Belo Horizonte: CEDEPLAR, 2008.

COSTA, C. C. M.; FERREIRA, M.A.M; BRAGA, M. J.; ABRANTES, L. A. Fatores associados à eficiência na alocação de recursos públicos à luz do modelo de regressão quantílica. Rev. Adm. Pública, Rio de Janeiro, v. 49, n. 5, p. 1319-1347, Oct. 2015. 
COSTA, O. G. P. O PAC e o Pacto Federativo. Revista Brasileira de Planejamento e Orçamento, v.3, nº 2, p. 146-173, 2013.

COWELL, F. A. Measuring inequality. Third edition. London: Oxford University Press, 2011.

CUMMINS, J.D.; XIE, X. Mergers and acquisitions in the US property-liability insurance industry: Productivity and efficiency effects. Journal of Banking \& Finance 32, p. $30-55,2008$.

DATASUS. Disponível em: http://www2.datasus.gov.br/DATASUS/index.php?area=02. Acesso em: 16 maio 2015.

DE MELLO, L.; TIONGSON, E.R. Income Inequality and Redistributive Government Spending. Public Finance Review. Volume 34, Number 3, May, p. 282-305. Sage Publications, 2006.

EASTERLY, W.; REBELO, S. Fiscal policy and economic growth: An empirical investigation. Journal of Monetary Economics 32, p. 417-458, 1993.

EASTERLY, W.; FISCHER, S. (2001). Ination and the Poor. Journal of Money, Credit, and Banking, 33 (2), 160-178, 2001.

FARREL, Michael J. The measurement of productive efficiency. Journal of the Royal Statistical Society. Series A, 120, p.253-281, 1957.

FERRAZ, L. F. Programa Bolsa Família: Impactos na Distribuição da Renda. Trabalho de conclusão de curso de pós-graduação lato sensu em Orçamento Público. Orçamento Público do Instituto Serzedello Corrêa Brasília: Instituto Serzedello Corrêa, 2008.

FIGINI, P. Inequality and growth revisited. Dublin, Ireland: Trinity College Press, 1998.

GARUDA, G. The Distributional Effects of IMF Programs: A Cross-Country Analysis. World Development, v. 28, jun., p. 1031-1051, 2000.

GHURA, D.; LEITE, C.A.; TSANGARIDES, C. Is growth enough? Macroeconomic Policy andPoverty Reduction. IMF Working Paper, WP/02/118, 2002.

GIACOMONI, J. Orçamento público. 16. ed. São Paulo: Atlas, 2012.

GIAMBIAGI, Fábio; ALÉM, Ana Claudia. Finanças Públicas. 2 ed. Rio de Janeiro: Elsevier, 2008.

GOUVEIA, M.; MASIA, N. A. Does the median voter explain the size of government? Evidence from the states. Public Choice, 97, p. 159-77, 1998.

GREENE, William H. Econometric analysis. 3. ed. New Jersey: Prentice-Hall, 1997. $1074 \mathrm{p}$. 
GRIGOLI, F. A Hybrid Aproach to Estimating the Efficiency of Public Spending on Education in Emerging and Developing Economies. IMF Working Paper, jan. 2014.

GUNTER, B.G.; COHEN, M.J.; LOFGREN, H. Analysing macro-poverty linkages: An overview. Development Policy Review, 23(3), 243-265, 2005.

HASSINE, Nadia Belhaj Economic Inequality in the Arab Region. World Development, v. 66, feb., p. 532-556, 2015.

HERRERA, S.; PANG, G. Efficiency of public spending in developing countries: an efficiency frontier aproach, IMF Working Paper, apr. 2005.

HOFFMANN, R. Distribuição de renda: medidas de desigualdade e pobreza. São Paulo: EdUSP, 1998.

HOFFMANN, R.. Desigualdade da renda e das despesas per capita no Brasil, em 20022003 e 2008-2009, e avaliação do grau de progressividade ou regressividade de parcelas da renda familiar. Econ. soc. [online], vol.19, n.3, pp. 647-66, 2010.

HOLZNER, M. Inequality, growth and public spending in Central, East and Southeast Europe. The Vienna Institute for International Economic Studies Working Papers, n. 71, 2011.

HSIAO, C. Analysis of Panel Data, 2nd edition, Cambridge: Cambridge University Press, 2003.

Instituto de Pesquisa Econômica Aplicada - IPEA (2015). IPEADATA. Disponível em https://www.tesouro.fazenda.gov.br/pt/contas-anuais. Acesso em 16 maio 2015.

JHA, R.; BISWAL, B.; BISWAL, U. D. An Empirical Analysis of the Impact of Public Expenditures on Education and Health on Poverty in Indian States. Queen's Institute for Economic Research, Discussion Paper 998, March, 2001.

KAKWANI, Nanak; NERI, Marcelo; SON, Hyun H. Linkages between pro-poor growth, social programmes and labour market: the recent Brazilian experience. Brasil: Pnud, 2006. (Working Paper n. 26).

KERSTENETZKY, C. L. Redistribuição e Desenvolvimento? A Economia Política do Programa Bolsa Família. DADOS - Revista de Ciências Sociais, Rio de Janeiro, Vol. $52, \mathrm{n}^{\circ} 1,2009$, p. 53 a 83.

KEYNES, J. M. [1973]. A teoria geral do emprego, do juro e da moeda. São Paulo: Nova Cultural, 1996.

KUZNETS, S. Economic growth and income inequality. American Economic Review, 45, p.1-28, 1995.

LIMA, G., MOREIRA, T. B. S, SOUZA, G. S. E. Eficiência dos gastos públicos no Brasil: análise dos determinantes da pobreza. Economia e Desenvolvimento, v. 12, p. 28-61, 2013. 
LIMA, G., MOREIRA, T. B. Fatores determinantes da desigualdade de renda no brasil: uma análise empírica. RDE - Revista de Desenvolvimento Econômico, v. 30, p. 7079, 2014.

LINDERT, P. H. (1996). What limits social spending? Explorations in Economic History, 33, p. 1-34, 1996.

LUNDBERG, M.; SQUIRE, L. The simultaneous evolution of growth and inequality. The Economic Journal, 113, p. 326-344, 2003.

MANDL, U.; DIERX, A.; ILZKOVITZ, F. The effectiveness and efficiency of public spending. European economy. Economic papers, 301, 2008.

MARINHO, E.; LINHARES, F.; CAMPELO, G. Os programas de transferência de renda do governo impactam a pobreza no Brasil?. Rev. Bras. Econ. [online], vol.65, n.3, pp.267-288, 2011.

MEDEIROS, M. Uma Introdução às Representações Gráficas da Desigualdade de Renda. Texto para discussão, 1202. Brasília: Instituto de Pesquisa Econômica Aplicada, 2006.

MEDEIROS, M.; BRITO, T.; SOARES, F. Programas focalizados de transferência de renda no Brasil: contribuições para o debate. Rio de Janeiro: Ipea, 2007 (Texto para discussão n. 1283).

MELTZER, A. H.; RICHARD, S. F. Tests of a rational theory of the size of government. Public Choice, 41, p. 403-418, 1993.

MENDES, M. J. A ineficiência do gasto no Brasil. Boletim de Desenvolvimento Fiscal, vol. 3, dez. 2006.

MESCHI, E.; VIVARELLI, M. Trade and Income Inequality in Developing Countries. World Development, 37(2), 287-302, 2009.

MILANOVIC, B. The Median-voter Hypothesis, Income Inequality, and Income Redistribution: an Empirical Test with Required Data, European Journal of Political Economy 16, 367-410, 2000.

MIRANDA, R. B. Uma avaliação da eficiência dos municípios brasileiros na provisão de serviços públicos usando "data envelopment analysis". Boletim de

Desenvolvimento Fiscal, v.3. Brasília: IPEA, 2006.

MUSGRAVE, R.A.; MUSGRAVE, P. B. Finanças Públicas: teoria e prática. Rio de Janeiro: Campus, 1980.

OATES, W. E. Federalismo fiscal. Madri: Instituto de Estudios de Administración Local, 1977.

, W. E. Toward a Second-Generation Theory of Fiscal Federalism.

International Tax and Public Finance 12, 349-373, 2006. 
W. E. On the Evolution of Fiscal Federalism: Theory and Institutions.

National Tax Journal, 61, 313-334, 2008.

Objetivos de Desenvolvimento do Milênio: Relatório Nacional de Acompanhamento. Coordenação: Instituto de Pesquisa Econômica Aplicada e Secretaria de Planejamento e Investimentos Estratégicos; supervisão: Grupo Técnico para o acompanhamento dos ODM. Brasília: Ipea: MP, SPI, 2014.

OBERDABERNIG, D. A. Revisiting the Effects of IMF Programs on Poverty and Inequality. World Development, 46. p. 113-142, 2013.

OLIVEIRA, D. B. O.; ZABOT, U. C.; SCHNEIDER, Y. F. Eficiência dos programas de transferências de renda e o desenvolvimento sócio econômico regional. In: Ciclo de palestras em Ciências Sociais Aplicadas, 3, Sinop, MT, 19-23 out., 2009.

Organização das Nações Unidas - ONU (2000). Declaração do Milênio. Nova York, 6 a 8 de setembro de 2000. Disponível em:

http://www.pnud.org.br/Docs/declaracao_do_milenio.pdf. Acesso em 04 maio, 2015.

PAES, N. L.; SIQUEIRA, M. L. Desenvolvimento regional e federalismo fiscal no Brasil: em busca da igualdade na distribuição de receitas. Economia Aplicada, 81, p. 707-742, 2008.

PANIZZA, U. Income inequality and economic growth: Evidence from American data. Inter-American Development BankWorking Paper, WP 404.Washington, DC, 1999.

PARTRIDGE, M. D. Is inequality harmful for growth? Comment. American Economic Review, 87, p. 1019-32, 1997.

PEÑA, C. R; PINHEIRO, D. S. ; ALBUQUERQUE, P. H. M. e FERNANDES, L. M. The effectiveness of income transfers: trends of inequality before and after Bolsa Família program. Rev. Adm. Pública, Rio de Janeiro, v. 49, n. 4, p. 889914, ago. 2015 .

PEROTTI, R. Income distribution, politics, and growth. American Economic Review, 82, p. 311-316, 1992. 1994. Income distribution and investment. European Economic Review 38:827-35, Growth, income distribution, and democracy: What the data say. Journal of Economic Growth, 1, p. 149-87, 1996.

PERSSON, T.; TABELLINI, G. Is inequality harmful for growth? Theory and evidence. American Economic Review, 84, p. 600-621, 1994.

POSTALI, Fernando A. S.; ROCHA, Fabiana. Resource windfalls, fiscal effort and public spending: evidence from Brazilian municipalities. New York: SSRN, 2009. (SSRN Working Paper, n. 1458085).

REZENDE, F. Finanças Públicas. 2. ed. São Paulo: Atlas, 2001. 
RIBEIRO, M. B.; RODRIGUES JÚNIOR, W. Eficiência do gasto público na América Latina. Boletim de Desenvolvimento Fiscal, vol. 3, dez. 2006.

ROCHA, S. Impacto sobre a pobreza dos novos programas federais de transferência de renda. In: Anais do Encontro Nacional de Economia. Brasília: Anpec, 2004.

Transferências de renda federais: focalização e impactos sobre pobreza e desigualdade. Revista de Economia Contemporânea, v. 9, n. 1, p. 67-95, jan./abr. 2008a. Transferência de renda focalizadas nos pobres - O BPC versus o Bolsa Família. Sinais Sociais, v. 3, n. 8, p. 150-186, set./dez. 2008b.

RODRIGUEZ, F. C. Does distributional skewness lead to redistribution? Evidence from the United States? Economics and Politics, 11, p.171-99, 1999.

RUGGIERO, J., VITALIANO, D.F. Assessing the efficiency of public schools using data envelopment analysis and frontier regression. Contemporary Economic Policy, 17(3), 321-331, 1999.

SCALON, C. Desigualdade, pobreza e políticas públicas: notas para um debate. Contemporânea, 1, p. 49-68, 2011.

SCHWELLNUS, C. Achieving Higher Performance: Enhancing spending efficiency in health and education in Mexico. Economics department working paper, n ${ }^{\circ} 732,2009$.

SECRETARIA DA RECEITA FEDERAL - SRFB. Arrecadação. Disponível em http://idg.receita.fazenda.gov.br/dados/receitadata. Acesso em 04 maio 2015.

SECRETARIA DO TESOURO NACIONAL - STN. Contas Nacionais. Disponível em https://www.tesouro.fazenda.gov.br/pt/contas-anuais. Acesso em 04 maio 2015.

SILVA, Mauro S. Teoria do federalismo fiscal: notas sobre as contribuições de Oates, Musgrave, Shah e Ter-Minassian. Nova Economia Belo Horizonte, vol. 15, n.1, p. 117-137, 2005.

SIMAR, L., WILSON, P.W. Estimation and inference in two stage, semi-parametric models of productive efficiency. Journal of Econometrics, 136, 31-64, 2007. $218,2011$.

Two-Stage DEA: Caveat emptor. Journal of Productivity Analysis, 36, 205-

SOARES, F. V.; SOARES, S.; Medeiros, M.; OSORIO, R. G. Programas de transferências de renda no Brasil: impactos sobre a desigualdade. Brasília: IPEA, 2006 (Texto para discussão n. 1.228).

SOUSA, M. C. S.; CRIBARI-NETO, F.; STOSIC, B. D. Explaining DEA technical efficiency scores in an outlier corrected environment: the case of public services in Brazilian municipalities. Brazilian Review of Econometrics, vol. 5, n. 2, p. 287-313, 2005. 
SOUZA JÚNIOR, C. V. N.; GASPARINI, C. E. Análise da eqüidade e da eficiência dos estados no contexto do federalismo fiscal brasileiro. Estudos Econômicos (São Paulo), 803-832, 2006.

SPANGER, U. Inequality-how to measure: a proposal on the way to better indicators. In: UNU/Wider conference on Inequality, Poverty and Human Well Being, 2003, Helsinki Finlândia. Poverty and Human Well Being, 2003.

SPANGER, U. Income inequality and poverty in Brazil: regional aspects of recent developments. In: Frontiers of Poverty Analysis, 2008, Helsinki Finlandia. Frontiers of Poverty Analysis, 2008.

SUTHERLAND, D.; PRICE, R.W.R; JOUMARD, I.; NICQ, C. Performance indicators for public spending efficiency in primary and secondary education. Paris: Economics Department/ OECD. OECD Economics Department Working Papers, n. 546, OECD Publishing, 2006.

SYLWESTER, K. Can education expenditures reduce income inequality? Economics of Education Review, 21, p. 43-52, 2002.

TANNINEN, H. Income inequality, government expenditures, and growth. Aplied Economics, 31, p.1109-1117, 1999.

TAVARES, P. A. PAZELLO, E. T.; FERNANDES, R.; CAMELO, R. S. Uma avaliação do Programa Bolsa Família: focalização e impacto na distribuição de renda e pobreza. Ribeirão Preto: [s.n.], 2008.

TER-MINASSIAN, T. Intergovernmental fiscal relations in a macroeconomic perspective: an overview. In. TER-MINASSIAN, T. Fiscal federalism in Theory and Practice. International Monetary Fund, p. 3-24, Washington: 1997.

THORBECKE, E.; CHUTATONG C. Economic Inequality and Its Socioeconomic Impac. World Development, v. 30, Issue 9, sep., p. 1477-1495, 2002.

TIEBOUT, C. M. A pure theory of local expenditure. Journal of Political Economy, n.64, p. 416-424, 1956.

TORRES, R. L. Licitações sustentáveis: sua importância e seu amparo constitucional e legal. Interesse Público - IP, Belo Horizonte, ano 14, n. 71, p. 219-241, jan./fev. 2012.

VAZ, A. C. N. Efeitos do Programa Bolsa Família (PBF) sobre a desigualdade e a extrema pobreza: análise e evidências a partir do Censo Demográfico 2010. Estudo Técnico, n.14. Brasília: Ministério do Desenvolvimento Social e Combate à Fome, 2013.

WANG, E. C.; ALVI, E. Relative Efficiency of Government Spending and Its Determinants: Evidence from OECD and Asian Countries. Eurasian Economic Review, v.1. n. 1, p. 3-28, 2011.

ZHANG, L. Political economy of income distribution dynamics. Journal of Development Economics, 87 (1), p. 119-139, 2008. 